الجمعية المصرية لتكنـولوجيا التهليم

إستزاتيمية هقتزحة قانيمة على الدهمج بين إستراتيجيتي التنظيم الذاتي للتعلم وهمتهمعات الاستقصاء عبر الويب، وأثرها على الهضهر المعرفي، والاجتماعي، والإنهاز الأكاديمي، والتعاهل هع الضغوط الأكاديمية لدى طلاب الدراسات العليا بكلية التزبية

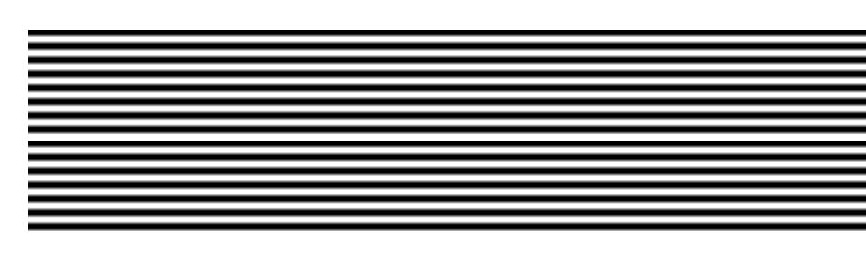
د. سعيد عبد الموجود على الأعصر

كلية التربية النوعية مساعد تكنولوجيا التعليم

الاستقصـاء عبـر الويسب في تنميـة الحضـور

المعرفي والاجتمـاعي، الإنجـاز الأكـاديمي، وتقليـل هستخالم البصث الضـوط الأكاديمية، ووجود دلالـة إحصـائية للفرق بين مرتفعي ومنخفضي التظيم الذاتي في الحضور

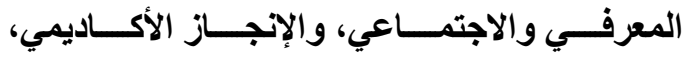
و الضـفوط الأكاديميـة لصـالح المسـتوى المرتفـع. ووجـود ارتبـاط موجـب بـين إسـتراتيجية التنظيم الــاتي والحضــور المعرفـي والإتجـاز الأكـاديمي، وسالب مع الضغوط الأكاديمية، وجود ارتباط موجب بـين الحضـور المعرفـي، والاجتمــاعي، والإنجـاز الأكاديمي، وسالب بين الإنجاز الأكـاديمي والضـوط الأكاديمية.

\title{
الكلمات الافتاحية:
}

التنظيم الـذاتي للتملم، مجتمعسات الاستقصـاء عبر الويسب، الحضـور المعرفي، الحضـور الاجتمــاعي، الضغوط الأكاديمية، الإنجاز الأكاديمي. يـهـــف هــذا البحــث إلــى الكثــف عـن أثــر إسـتراتيجية قائمسة على الـدمج بـين إسـتراتيجيتي التتظيم الـذاتي للتعلم ومجتمعـات الاستقصـاء عبـر الويـب، علــى الحضـور المعرفـي، والاجتمــاعي، والإنجاز الأكاديمي، والتعامل مع الضغوط الأكاديمية لدى طلاب الدراسـات العليا بكليـة التربيـة، حيث تم اســتخدام مــنهج البحــث التطــــيري، وتطبيـثق الإســتراتيجية علــى (Y (Y) طالبًا، وإعـداد قائمــة بالمعاييز التصميمة، ومقاييس لد: الحضور المعرفي الاجتمــاعي والتدريسـي، التنظـيم الـــاتي للـتـعلم، الضــذوط الأكاديميــة، ثــم المعالجــات الإحصـــائية باستخدام: الإحصاء الوصفي، اختبار t-test للفرق بين المتوسـطات، واختبـار Mann Whitney بـ معساملات الارتبـاط، وتوصـلت النتـائج إلـى فاعليـة إستراتيجية التعلم المنظم ذاتيًا في مجتمعات 
الجمعية المصرية لتكنولوجيا التعليم

والاستقصساء، وتزيــ من مسـاهمة المتعلم في بنـاء مقدمهة.

مجتمعـات التعلم وتثــارك المـوارد، والانخراط في

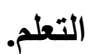

وتؤكـــ عديـــ مـن الدراسـات أن قـدرة بيئـات

التعلم عبر الإنترنت على استيعاب تلك التحديات، وتحقيق الكفاءة والفاعلية في التعلم يرتبط بقدرتها علــى زيـــادة مســتويات التفـــاعلات التعليميــة

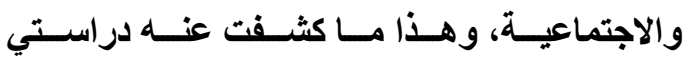
(Anderson, 2017 ; ' 'أندرسون ونولان جرانت Nolan-Grant, 2019) عنصر التفـاعلات التعليميـة والقدرة على التثـارك فــي مــوارد الــتعلم، والتواصـل المتـزامن وغيـر المتزامن، من المعايير المهمـة للحكم على فاعليـة بيئـات التتعلم عبـر الإنترنـت، كمـا أشـارت دراسـتا (Zhang et al.,2019; هـانج وزارزور Zarzour et al.,2020) تصميم وتوظيف بيئات التعلم عبر الإنترنت؛ فإن ذلك ينتج عنـه بالتبعيـة تعزيز التفـاعلات التعليميـة وتتويعها، حيث توجد علاقة ارتباطية موجبة بين كفـاءة تصـيم وتتظيم بيئـات التعلم عبر الإنترنت،

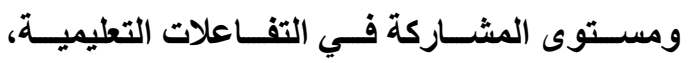
وحدوث التعلم العميق أو الأصيل. وبـالرغم مـن تأكــــ دور التفــاعلات التعليميـة

' استخدم الباحث في التوثيق وكتابة المراجع الإصدار السـابع

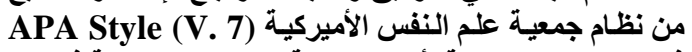

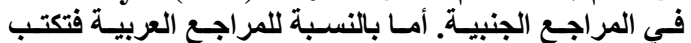
الأسماء كاملة كما هي معروفة في البيئة العربية.

في ظل تنامي التداعيات المختلفة والتطورات

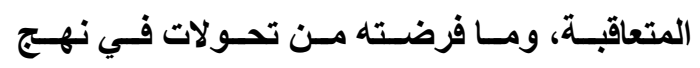
المؤسســات التعليميـة، وتبنيهـا لبيئسات ومجتمعـات التعلم عبر الإنترنت، ظهرت تحديات عديدة، يتمثل أبرزها في كيفية الحفاظ على استمرارية المتعلمين في التتعلم، والثـعور بمجتمعـات التعلم، والانتمساء لها، وتمشيًا مع هذا التحدي، فإن الحاجة تدعو إلى تركيز البحوث والدراسات في تناول متغيرات البحث التي تلدعم التفاعلات التعليمية والاجتماعية، وتُسـهر لهري في زيادة الثعور بالاتتمـاء لمجتمع التعلم، والتوقع الإيجـابي لنوايسا وقابليـة الاسـتخدام في المسـتقبل. وكنتيجـة طبيعيـة لتلــك التطـورات أصسبحت بيئـات الـتـعم عبـر الإنترنــت جـزعًا لا يتجـزأ مـن الواقـع

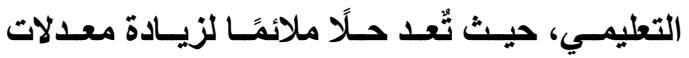
الالتحاق بالتعليم، كما تعد أحد البدائل الرئيسية في مواجهة عديد من التحديات والأخطار، ممـا فرض الرض على مصمي ومطوري بيئات التعلم عبر الإنترنت

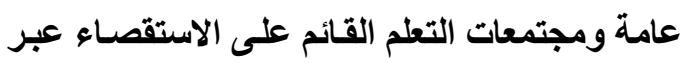
الويب خاصة، عديد من التحديات من بينها الحاجـة لإدراك العوامل والمتغيرات التي من شـأنها تعزيز فاعلية بيئات التعلم عبر الإنترنت، كمـا فرضت تلكت فلك التحسيات ضــرورة البحـث فـي متغيـرات تصــميم وتظوير مجتمعات الاستقصساء عبر الويب؛ لمسا لها

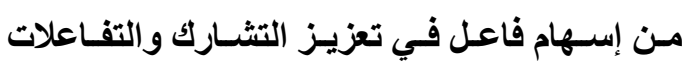
التعليميـة، وإتاحسة الفرصـة لتوظيف إسـتراتيجيات تعلـيم وتعلـم تــــم عمليـات البحــ، والاكتثــاف، 
الجمعية المصرية لتكنـولوجيا التنعليم

التعلم القائم على الاستقصاء عبارة عن إطـار بنـائي

اجتمــاعي لعمليـات الـتعلم فـي بيئـات الـتعلم عبـر

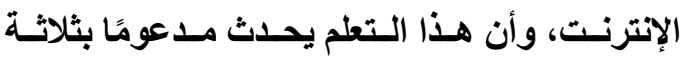

أشـكال مسن التفــاعلات هـى الحضــور المعرفـي،

والاجتماعي، والتدريسي، وهذا التوع من مجتمعات التعلم يتيح الفرصـة للمتعلمين لتحقيث أهدافهم من خـلال ممارســة ســلوكيات الحضــور الاجتمــاعي والمعرفي، ممـا يـؤدي لزيـادة الفهم والانخراط في

التعلم.

وتُعد مجتمعـات التعلم القائم على الاستقصـاء

عبر الويب، من النماذج المدعومة بعديد من الآراء

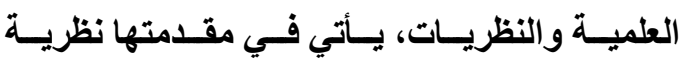

Online متمعسات الاستقصـاء عبـر الإنترنـت community of inquiry theory طـورت لوصسف كيفيـة تلبيـة احتياجـات المعلمـين والمتعلمــين للحضــــور المعرفـــي والتعليمــي والاجتماعي، وتؤكد تلك النظريـة أن المتعلم بحاجـة للحضور بأنواعه الثلاثةة، وتقدم عددًا من الإرشادات بثــأن إســتراتيجيات تعزيــز الحضـــور بأنواعــه (Garrison \& Anderson, 2003)، وكذلك Transactional نظريسـة الفضــاء المعرفـي Distance Theory حيث تفترض تلكت النظريـة أنـه لحدوث التعلم يجب توفر ثلاثة مكونـات رئيسية لبنـاء مجتمعسات التعلم هـى: التفـاعلات بـين المتعلمسين والمعلمسين، هيكل

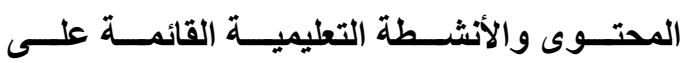

والتشــارك فـي تحقيـق فاعليـة الـتعلم؛ إلا أن لـي وآخرين Lee et al.2020 قد توصلوا إلى نتائج تُظهـر وجـود تصــورات سـلبية لــدى المعلمـين والمتعلمين نحو بيئـات التعلم عبر الإنترنت، حيث يرونها صورة من صور بيئات التعلم التقليديـة، لكن باسـتخدام التطبيقـات الرقميـة، لذا أوصـت الاراسـة بضرورة فهم العوامل التي من شـأنها معالجـة أوجها القصــور، وفــي الســياق ذذاتـــه أكــــــــــومبرج Bloomberg (2020) مميزات بيئـات التتعلم عبـر الإنترنـت ؛ إلا أن هنـاك عنصـرًا مفقـودًا يتعلق بتعزيـز الترابط الاجتمــاعي له وتفـاعلات الأقران. كمـا أشـارت دراسـة وي ونيـان Wu and Nian (2021) للبحث في إستراتيجيات تكامل الأدوار بين المعلمين والمتعلمـين فـي بيـــات الـتعلم، وتعزيـز التــرابط الاجتماعي بين المتعلمين وزيـادة الشـعور بالانتمـاء لبئة التعلم. وفي ظل تأكيــ أهميـة التفـاعلات الاجتماعيـة والتعليميـة، وتعزيز الحضور الاجتمـاعي والمعرفي في بيئات التعلم عبر الإتترنت، ظهر مجتمعات التعلم القـائم على الاستقصـاء عبـر الويـب، والـذي يُعـــ بمثابة إطارًا لفهم وتفسير وتتظيم سلوكيات المتعلم وتفاعلاتهـ، كمـا يُعـد نموذجًا لتفسـير العلاقـات بين أنواع الحضور المعرفي، والاجتمـاعي والتدريسي، بمـا يضـمن تخطيط إسـراتيجيات التعزيز المناسبة كل نوع. ويرى صوان Swan (2019) أن مجتمع تصكنولوجيا التعليـ . . . . سلسلةدماساتوبجوثمُحهمَة 
الجمعية المصرية لتكنولوجيا التعليم

وجـود تـأثير إيجـابي لمجتمعسات التتعلم القـائم على الاستقصـاء عبر الإنترنت على الاتجـاه نحو التعلم والإنجاز الأكاديمي، وكثفت نتائج دراسـة بوبيسكو و بادى (2020) Popescu and Badea عن تحقيق مجتمعات التعلم القائم على الاستقصـاء عبر الإنترنت لتأثير إيجابي بالنسبة للحضور الاجتمساعي والمعرفي، وكنلك دراسة ياندرا وآخرين Yandra et al. (2021) (التي أشـارت إلى وجـود علاقـة إيجابية بين مجتمعات التطم القائم على الاستقصاء عبر الإنترنـت وتحسـين الكفـاءة الذاتيـة، وبالتـالي تحسـين جـودة الـتطلم، وتوصـلت دراسـة كاسـتل Castle (2014) لوجـود علاقـة بـين مسـتوى المشـاركة فـي بنـاء مجتمعـات الـتعلم القـائم على لهـ الاستقصاء عبر الإنترنت ومستوى حاجة المتعلمين لـلإدراك، بمـا يحقق الانخر اط في التعلم، كمـا أثــار روهايمن وآخرون Rohimin et al.(2020) إلى فاعلية مجتمعات التعلم القائم على الاستقصساء عبر الإنترنت في تحسين معدلات الإنجاز، مقارنة بالتعلم التعـاوني عبـر الإنترنــت، أمسا هريـانتي وزمـلاؤه فتوصـلوا في Herayanti et al. (2020) دراستهم إلى فاعليـة مجتمعـات التتطم القـائم على الاستقصـاء عبر الإنترنتـ في تنميـة مهـارات حل المشـكلات وتحسـين الاتجاهــات مقارنــة بــالتعلم المدمج.

ولــم يقتصـر الأمسر عنــــ الكثـف عـن فاعليـة مجتمعــات الــتعلم القــائم علـــى الاستقصــاء عبــر
الاستقصــاء، الــتحكم الـذاتي واسـتقلالية المـتعلم

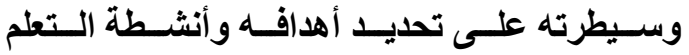
وإجراعات تنفيذه ومراقبته وتقييمه، وتؤكد النظريـة على ضرورة مراعاة المسـاحة النفسية والتفاعليـة و التواصلية بـين المعلـم والمـتعلم خـلال مجتمعـات التعلم عبر الإنترنت، وترنكز مجتمعات التعلم القائم على الاستقصاء عبر الويب إلى نظريات أخرى مثل: المعرفيـــة الاجتماعيـــة، البنائيـــة الاجتماعيـــة، و التواصلية أو الترابطية، والتي تلتقي جميعها في أن التعلم يحدث نتيجة التشارك والتفاعل بين المتعلم والمعلم وعناصر سيات التعلم، والذي يتطلب بدوره تنويع فرص التفاعل التي تعزز قدرة المتعلمين على توليد الأفكار، وتثــارك وجهات النظر والمعسارف، واتسـاع نطـاق البحث و التفكير، وتحقيق مستوى مناسب من المهارات فوق العرفية. وقد اهتمت عديد من الاراسـات بالكشف عن فاعلية مجتمعات التعلم القـائم على الاستقصـاء عبر Akyol الويب، حيث أجرى أكويلـل وجارسيون and Garrison (2008) إلسى أن مجتمعـات الاستقصـاء عبـر الويـب تسـهم بفاعلية في تطوير الحضور المعرفي والاجتمـاعي Kilis and والتدريسي، كمسا أثسار كيلز ويلترم Yildirim (2018) الويب تحقق نتائج إيجابيـة بالنسبة للتنظيم الذاتي والمهــارات فــوق المعرفيـة و الدافعيـة، أمـا ميلـر وآخرون Miller et al. (2020) فقد توصلوا إلى 
الجمعية المصرية لتكنـولوجيا التعليم

الإنترنتـ؛ بـل اهتمـت بعض الدراسـات بالبحث في

وهنــاك مجموعـة مـن التــديات المرتبطــة بالتـاعيات والتحولات الرقميـة، وانتثـار مجتمعـات التعلم عبر الإتترنت، ومن بين تلكك التحديات: تنوع المصـادر والمـوارد المتاحـة في بيئـات التتطلم عبر الإنترنتـ، حاجـة المـعلم إلـى الاستقلالية والتحفيز الأتي المستمر، الحاجـة لقدر كبير من الاستقلالية وتحمـل مســؤولية الـتعلم، حاجـة المـتعلم للشـعور بالانتماء لمجتمع التعلم والنشاط والإيجابية وتطوير المعتقات بثأن الفوائد المتحققة من التعلم والقيمـة المُدركة له، وللتعامل مع تلكك التحديات فِإن المتعلم بحاجة ضرورية لأن يكون قادرًا على تنظيم وإدارة تعلمه ذاتيًا.

ويُعد التظظيم الذاتي للتعلم معيارًا للحكم على فاعليـة مجتمعـات التعلم الاستقصسائي عبر الويب، وخاصة في تطوير الحضور المعرفي والاجتماعي، وتحقيق مستوى عالي من الإتجاز الأكاديمي. ويرى دينث وباتلر Dignath and Buttner (2018) أن التظيم الأتي للتعلم يشير إلى قدرة المتعلم على إدراك سياق التعلم و إدارتهـ من خلال مجموعة من العمليـات التـي تتضــن تحديــ الأهـداف وتخطيط التوقعات، والتحكم الذاتي، والتقييم الذاتي، والتحفيز الذاتي وصولًا لتحقيق الأهداف المطلوبـة، كمـا يؤكد de la Fuente et al. دو لا فوينتي وآخرون

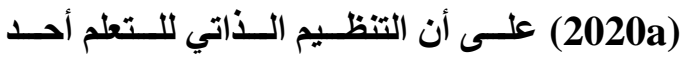

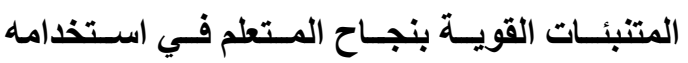

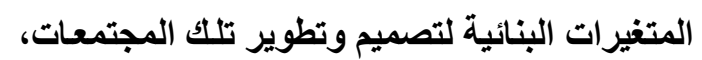

Anderson يـث أجسرى أندرسـون (2016) دراسـة توصل فيها لمجموعة من الإرشـادات التي توضسح كيفيـة الاسـتفادة مسن تلـك المجتمعسات في تلي التعليم والتعلم الرقمي، أما نولان-جرانيت - Nolan Grant (2019) التوصــيات بثـــأن كيفـــة اســتخدام مجتمعسـات الاستقصــاء عبــر الإنترنـــت كنمــوذج للتصــميم Xing and التعليمس. وأجرى تثــاينج وتثثـاو Gao (2018) خصــائص الحـوار عبـر الإنترنــت واسـتمرارية

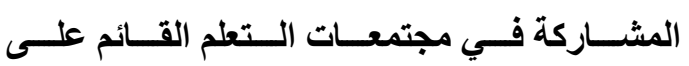
الاستقصـــــاء، أمــــــا جيمـــــونيس و روســــنس Jimoyiannis and Roussinos (2017) فبحثـا في دراستهما أنمـاط تثـــارك المتعلمـين في محررات الويب التثــاركية Wiki كمجتمع للتعلم الاستقصسائي عبر الإنترنست. واهتمـت دراسـة جـو Goh (2020) لفهم طبيعة مجتمعات الاستقصاء عبر الإنترنت. كما أوصت عديد من الدراسـات بضرورة الاستنتاد إلى النماذج والأطر الإرشـادية لتصميم وبنـاء مجتمعات التطلم القائم على الاستقصاء عبر الإنترنت Chen) et al., 2017; Tao \& Zhang, 2018; Hatmanto \& Pratolo, 2020; Bloomberg, 2020; Fiock, 2020; Heilporn \& Lakhal,

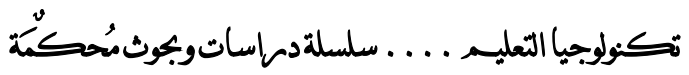


الجمعية المصرية لتكنولوجيا التعليم

دو ويونتك Doo and Bonk (2020) إلى وجود تأثير إيجابي للتنظيم الذاتي للتعلم على الحضسور الاجتمساعي و المشــاركة في مجتمعسات التتعلم عبر الإتترنت، ويرى زنـج (2020) Zheng أن الطلاب ذوي المستوى المنخفض في التظيم الذاتي للتعلم، تكون معدلات أدائهم الأكساديمي منذفضـة، وهذا مـا

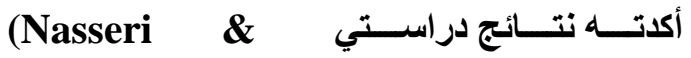
Motallebzadeh, 2016; Altay \& حيــث أكــتا علــى أن Saracaloglu, 2017) الطـلاب الـــين يســتخدون مســتويات أعلـى مسن مهارات التنظيم الذاتي للتعلم، يظهرون مستويات أعلى في التفكير والمهارات فوق المعرفية، وقبول الاستخدام لمجتمعات التطلم عبر الإنترنت، لذا أكدت (Kilis \& Yildirim, 2018; de la دراسـات Fuente et al., 2020-b; Wong et al., 2020; Schumacher \& Ifenthaler, (2021 علـى مزيــد مـن البحـث فـي كيفيـة تعزيـز

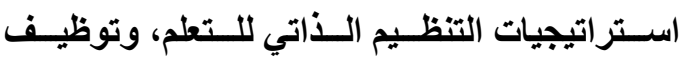
محفزات تطوير تلكك الإستراتيجيات في مجتمعـات التعلم الاستقصائي عبر الإتترنت.

لـذلك يسـتخدم الباحـث اسـتراتيجيات التنظيم الذاتي للتعلم في مجتمعات الاستقصـاء عبر الويب في هذا البحـث بهـدف تنميـة الحضـور المعرفي، والاجتمــاعي، والإتجــاز الأكـاديمي، والتعامـل مـعـ الضنوط الأكاديمية لدى طلاب الدراسـات العليـا في كلية التربية
لإســتر اتيجيات التعامـل مــع الضــوط الأكاديميــة وتحقيق الإنجاز الأكاديمي، وترتبط الكفاءة الذاتيـة في التعلم بقدرة المتعلم على التنظيم الذاتي لتعلمـه، حيث إن معتقدات المتعلم عن كفاعته الذاتية وثقتـهـ بذاتـه، ترتبط بمهاراتـه في تخطيط تعلمهـه ومراقبـة معدل تقدمه وتقييم أدائهـ باستمر ار وتصحيح مسـار تعلمه وتوجيه جهوده نحو التعلم Zimmerman) (\& Schunk, 2011) ويـرى لـودج وآخرون Lodge et al. (2018) يولا مستويات عاليـة من الدافعيـة والتحفيز الذاتي والتـي تُعـالج مشـكلة بقـاء المتعلمسين لوقت طويـل خلال مجتمعات الاستقصاء عبر الإنترنت. وقد اهتمت عديد من الاراسـات بالكشف عن العلاقـة بـين إسـتراتيجيات التظظيم الــاتي للـتعلم وجوانـب الـتـعم الأخـرى، حيـث أثـــارت دراسـة باسدوجان Basdogan (2015) إلى وجود ارتباط إيجابي بين مستوى استخذام إستراتيجيات التعلم المُـنظم ذاتيَّا ومســتوى الحضــور الاجتمــاعي فـي مجتمعات التعلم الاستقصسائي عبر الويب، وتوصل Broadbent and Poon برودبنـت ويسون (2015) لوجود علاقة بين استخدام إستراتيجيات التظيم الذاتي للتعلم والإنجاز الأكاديمي، ويأتي هذا

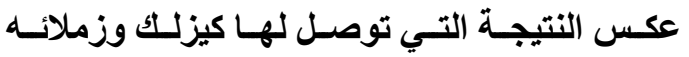
Kizilcec et al. (2017) الاراسة إلى وجود تأثير سلبي لبعض استراتيجيات التنظيم الذاتي للتعلم والإنجاز الأكـاديمي، وتوصل 
الجمعية المصرية لتكنـولوجيا التهليم

تناولت أهمية الحضور الاجتمساعي، كشفت دراسـات عديدة عن وجود ارتباط بين مستوى توفر الحضور الاجتماعي في بيئات التعلم عبر الإنترنت، وكفـاءة مخرجات التعلم، حيث أشـارت نتـائج دراسـة أكيوال وجارسيون Akyol and Garrison (2008) إلى وجـود ارتبـاط موجـب بـين الحضـور الاجتمــاعي والرضا عن التعلم في بيئات التعلم عبر الإنترنت، Joksimovic et ويوكد جوكسيموفك وآخرون al. (2015) أن الحضور الاجتماعي أحد المؤشرات المنبئـة بـالأداء الأكـاديمي، ويتفـق معهـم كـوزان Kozan (2016 فـي الاسـتناد إلـى الحضــور الاجتمـاعي كعامـل منبـئ بالعب اءع المعرفي، أمـا مـا وزملائسه (2017) فأشـاروا إلى وجود علاقة إيجابيـة بـين الحضـور الاجتمـاعي والاتجـاه نحو التعلم وبيئة التعلم عبر الإنترنت، وتأكد ذلك Costley (2019) أيضًا من خلال دراسـة كوستلي حيـث كثـفت نتائجهـا عـن ارتبـاط إيجـابي بـين الحضـور الاجتمــاعي والعـبء المعرفي الوثيـث أو المـرتبط، ويسـهم الحضـور الاجتمــاعي أيضُّـا في تعزيـز مهـارات التفكيـر الناقـد Costley \& .Lange, 2016)

ويمكـن القــول أن العلاقــة بـين الحضــور الاجتمـاعي ومخرجـات التتعلم علاقـة تبادليـة، حيـث أشــار هـورزام (2017) أن مستتوى مشــاركة المـتـعلم فــي التفــاعلات الاجتمـاعــة يُعـد مؤشرًا قويًا للحضور الاجتماعي، كمـا أشـار مالجانـا
ويُعـد الحضــور الاجتمــاعي بمثابـة المكـون المسؤول عن التقاعلات الاجتماعية، والتشسارك بين المتعلمـين وبعضــهم، وبيـنهم وبـين المعــم، حيـث يشير الحضور الاجتماعي إلى مجموعة السلوكيات التـي يمارســها المـتعلم للتعبيـر عن ذاتـه، وتعزيـز التـرابط مــع أقرانـه، والتعبيـر عـن رأيسه وإبـراز شخصــيته ونقـــاط تمبـزه، باســتخدام التعبيــرات العاطفية والتلميحات الاجتماعيـة ووسـائل التواصل

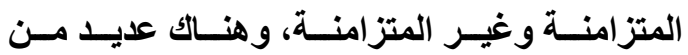
التوجهـات والآراء النظريــة التـي تــــعم الحضــور الاجتمـاعي، من بين تلك التوجهات نظريـة الترابط Morton الاجتماعي التي طورهـا مورتن دويتش Deutsch هيكلة وتنظيم علاقـات الترابط بين المتعلمين تؤثر إيجابًا فيحدث الترابط، أو سلبًا، فيحدث التتافس، أو ينعـدم التـأثثر فتحدث الفرديـة في التعلم، وأكدت التظرية على أن التعلم هو نتاج الترابط الاجتمـاعي (Lee \& Huang, وتكوين مجتمعـات التعلم (2018، كما أن نظرية البنائية الاجتماعية هى أيضًا مــن التوجهــــات التظريــــة الاعاعــــة للحضــــور الاجتماعي، حيث ترى أن المتعلم لا يمكن فصله عن سياق التعلم والتأثيرات الاجتماعية التي تحدث في بيئة التعلم، ولكي يحدث التعلم الفعـال، لابـد مـن البحث في كيفية زيادة مستوى الحضور الاجتمـاعي وعلى مستوى نتائج الدراسـات التجريبية التي

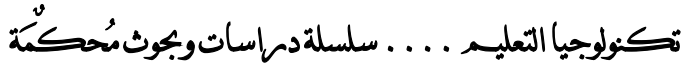


وفــي ســياق استكثــاف فاعليـة الحضــور

المعرفي عمليًا، أكد كوزان (2016) Kozan أن

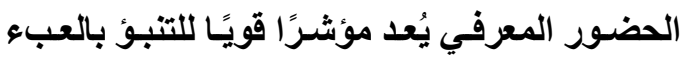
المعرفي الاخيل والعبء المعرفي الكلي. أمسا كوزان

Kozan and Richardson وريتشاردسون (2014) فقـــ توصـلا إلـى وجـود علاقـة ارتباطيـة تبادلية بين الحضور المعرفي والعضور الاجتمـاعي والحضور التدريسي، وأن الحضور المعرفي يؤثر على العلاقـة بـين الحضـور الاجتمساعي والحضـور التدريسـي، ويـرتبط إيجابيًا مـع الرضـا عن التتعلم والإنجــاز الأكـــاديمي، كمـــا أثــــار مالجانــا ولــو Muljana and Luo (2019) في التعلم والثـعور بالانتمـاء لمجتمـع التعلم يرتبط بثكل إيجابي بالعضور المعرفي للمتعلم. ويُعـــ الإنجـاز الأكـاديمي مـن الأهــاف التـي تسعى دومًا بيئات التعلم لتحقيقها، حيث يُعد بمثابـة مؤشر لنجاح بيئة التعلم في تحقيق أهدافها، ومن ثم الرضـا عن التعلم وزيـادة القابليـة لاستخدام بيئـات التتطم، وتزايـــ أعداد الملتحقين بهـا، ومسن خـلال تحليل نتـائج الاراسـات التـي اهتمـت بالكثـف عن تـأثير الحضـور بأنواعـه ضـمن بيئـات الـتعلم عبر (Kozan \& Richardson, 2014; الإنترنت Joksimovic et al., 2015; GutierrezSantiuste et al., 2015; Kozan, 2016; Ma et al., 2017; Richardson et al., 2017; Costley, 2019; Muljana \& Luo,
ولـو (2019) Muljana and Luo إلسى أن الانخراط في التعلم والثعور بالانتماء لمجتمع التعلم يرتبط إيجابيًا بالحضور الاجتمـاعي للمتطلم، ويؤكد Sozan and Richardson (2014) الحضــور الاجتمــاعي والنــوعين الآخـرين مـن الحضور وهما التدريسي والمعرفي، حيث يؤثر كل نوع في حدوث النـوعين الآخرين وطبيعـة العلاقة بينهمـا، وهــا مــا أكلتـه نتــائج دراسـة جـوتيرز وزملائسه Gutierrez-Santiuste et al. (2015) عندما توصلت إلى أن الحضور الاجتمـاعي عامل منبئ بالحضور المعرفي. ولا تقتصر منبئات فاعلية مجتمعات التعلم عبر الإنترنت على الحضور الاجتمـاعي فقط؛ بل تثـمل صسورة أخرى مـن صسور الحضسور وهـو الحضـور المعرفي أو الإدراكي، حيث يشير الحضور المعرفي إلى مستوى إدراك المتعلم لبيئة التطلم ومشاركته في بناء مجتمع التعلم، وطرح الأسئلة والاستفسـارات، وتبريـر وجهـات النظـر والتفاعـل مــع المصــادر و التطبيقات المتاحة، والفاعلية في تحديد التوقعات وتخطيط الأهداف، واختيـار الاستراتيجيات الملائمسة لتحقيقها، ويرتبط الحضور المعرفي بقدرة المتعلم علـى الاحتفــاظ بالمعسارف والمفــاهيم، مسن خـلال ممارسـة مهارات التفكير، و البحث عن المعلومـات مـن مصسادرها، والتحفيز الذاتي والدافعيـة للتعلم، وربط المعارف النظرية بالتطبيقات العملية لها. 
الجمعية المصرية لتكنولوجيا التعليم

واهتمت عديد من الاراسـات بالبحث في تأثثير

الضغوط الأكاديمية على نتائج التعلم، حيث أشارت

Yildirim et al. دراسـة يلدرم وآخرين (2017) إلسى وجـود علاقـة سـبيبة بـين الضـفوط الأكاديميـة وتقدير الذات والحضور الاجتمـاعي، حيث يتأثران سـلبًا بزيـادة الضـفوط الأكاديميـة، وتوصلت نتـائج

Kر اسـة كارمسان وواتسـون Karaman and Watson (2017) لوجـود علاقـة بـين الضـغوط الأكاديمية ومستوى الادفعية للإنجاز، واتفقت معها

Pascoe et al. نتائج دراسـة باسكو وآخرين (2020) فتوصلوا لوجود علاقة قوية بين مستوى الضـفوط الأكاديميـة و التحصيل الدراسـي والدافعيـة نحو التعلم، ويؤكد بريفكت وزملاؤه Perfect et أن الضغوط الأكاديمية تؤثر سلبًا على al. (2016) القدرات العقلية وعمليات التركيز والاتتباه، وأكدت

Shorer and دراسـة شــورر وليبـوفتش Leibovich (2020) ارتبـاط عكسـي بـين مسـتوى الضــوط الأكاديميـة والإنجـاز الأكـاديمي والتحصيل، كمـا تؤكد دراسـات

(Zenner et al., 2014; Bedewy \& Gabriel, 2015; Vohs \& Baumeister, 2016; Kaunhoven \& Dorgee, 2017; Mcclelland et al., 2018) بين مستوى مهارات التظيم الذاتي للتعلم، والكفاء فـي التعامـل مــع الضــوط الأكاديميـة (مجموعـة المعارف والمهارات المعرفيـة ومـا وراء المعرفيـة،
2019; Nasir, 2020) وجـود ارتبـاط موجب بـين تـوفر صـور الحضـور، ونــواتج الـتـلم المتحققـة مثـل: العبـ المعرفي، الرضا عن التعلم، الاتجـاه نحو التعلم وبيئة التعلم، القابليـة للاستخدام، الانخر اط في التعلم، حيث تُعد تللك النواتج دلالة على الإتجاز الأكاديمي. وتُعد الضـغوط الأكاديميـة بمثابـة ظـاهرة يعـاني منهـا الطـلاب، خاصـة في ظل بيئـات التـلم عبـر الإنترنت وما يرتبط بخصائصها، سواء وفرة وتتوع المصادر والموارد، الاستقلالية وتحمل المسؤولية، كثرة المهام والتكليفات، التقييم عبر الإنترنت وتنوع

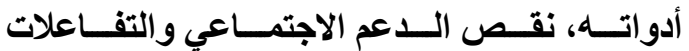
الاجتماعيـة العضـورية، التقدير المـنخفض للـات، نقص الكفاءة الأتية، الخوف من الفشل في تكوين علاقـات ناجحة مـع الآخرين، الحاجـة لقضـاء وقت تعلـم أطول، التصـورات السـلبية نحو بيئسة التعلم؛

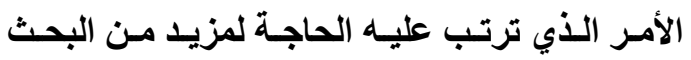

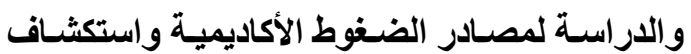
إستر اتيجيات التعامـل معها، بمـا يقلّل مـن تأثير هـا، وتثـير الضـفوط الأكاديميـة إلى الحالـة العقليـة أو العاطفيـة أوكليهمـا التي يشـعر بها طالب الدراسـات

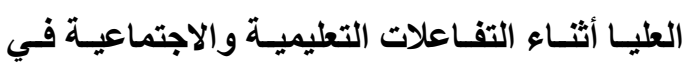
مجتمعـات الاستقصــاء عبـر الويـب، والمرتبطــة بالأعبـاء الناتجـة عـن تنفيــذ المهــام والأنثـــة

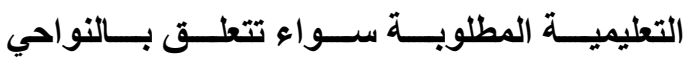
السيكولوجية أو الفسيولوجية. تكنولوجيا التعليـم ... . سلسلةدهراساتوبجوثمُحطمّة 
وبين الحضور الاجتماعي والمعرفي ونـواتج التعلم، وأيضًا باعتبـار التظظيم الذاتي للتعلم مطبًَا رئيسيًا عنــ تصـميم وتطوير مجتمعـات التعلم الاستقصسائي التي أكدت الار اسـات السـابقة على ضرورة البحث فيها، ظهرث الحاجة للبحث في كيفية الاستفادة من المميزات التي تحققها إستراتيجيات التنظيم الذاتي للتعطم، وفي الوقت ذاتـه التظلب على المشـكلات المرتبطـة بمجتمعـات الاستقصـاء عبر الويـب؛ بمـا يُحسن من فاعليتها، من خـلال تصميم إستراتيجية تــدمُج بـين إســتراتيجية التنظــيم الــذاتي للــتعلم ومجتمعـات الاستقصـاء عبر الويب ، وتأكدت هذه الحاجـة مسن تبـاين نتـائج الار اسـات السـابقة بشـأن فعالية إستراتيجيات التظيم الذاتي للتعلم، وعلاقتها بمخرجـات التعلم المختلفـة، وممــا سـبق يسـتخلص الباحـث أنــه يمكـن توظيـف إسـتراتيجيات التنظيم الأاتي للتعلم في تطوير مجتمعًا للتعلم الاستقصسائي عبـر الويـب بـهـدف تنميـة الحضــور الاجتمــاعي والمعرفــي، والإتجــاز الأكــاديمي، والتعامـلـل مــع الضغوط الأكاديمية لاى طلاب الار اسـات العليا. هماثة البمث. نبعت مشكثة البحث من خلال الأبعاد الآتية: أولَا: الحاجــة إلـــى تتميــة الحضـــور الاجتمـــاعي و المعرفـى والإنجـاز الأكـاديمى، وتقليـل الضـغوط الأكاديمية لدى لطلاب الدراسات العليا بكلية التربية. - لا شك أن الحضور الاجتمـاعي والمعرفي من
والتصــور ات، والمعتقـــات، التــي يمكـن للمـتعلم استخدامها في مواجهة الضـغوط الأكاديمية وتقليل أثثار ها)، حيث يسهم التتظيم الذاتي للتعلم في زيادة الفعالية الذاتية، والكفاءة الذاتية في التعامل مع بيئة الـتعلم، وإدارة وقـت الـتعلم بشـكل جيـد، وتنظـيم الجهود، وتخطيط الأهداف، وتحديـ معايير التقيـيم في ضوء الإمكانات والقدرات، وبالتالي تخفيف أثار الضغوط الأكاديمية. من خلال ما سبق يتضح تأكيد نتائج الدراسـات السابقة على أهمية الحضور المعرفي والاجتمـاعي؛ لمـا لهمـا مسن تـأثير إيجـابي على مخرجـات التتعلم المختلفـة وبخاصـة الإنجـاز الأكـاديمي، حيث أثبتـت تلكك الدراسـات وجود ارتبـاط إيجـابي بين الحضور الاجتمــاعي والمعرفـي والإنجـاز الأكـاديمي، كمــا أشارت نتائج تحليلات التعلم أنـه من خـلال الحضور الاجتمـــاعي والمعرفــي يمكــن التبـــؤ بالإنجـــاز الأكـاديمي، ممــا فـرض وجـود حاجـة للبحـث في العوامل التي يمكن أن تسـهم في تطوير الحضـور الاجتماعي والمعرفي، وفي ضوء الفعالية التعليمية لمجتمعـات الـتعلم الاستقصـائي عبـر الويـب التـي كثـفت عنهـا نتــائج الار اســات الســابقة، ظهـرت الحاجة لاستخدام مجتمعات التعلم الاستقصـائي عبر الويسب لتتميـة الحضــور الاجتمــاعي والمعرفـي، وبالتـالي زيـادة معـدلات الإنجـاز الأكـاديمي، وفي ضـوء نتـائج الدراسـات السـابقة التي أكدت أهميـة التتظيم الذاتي للتعلم، ووجـود علاقة تبادليـة بينـه 
الجمعية المصرية لتكنـولوهيا التعليم

والتحفيـز الــذاتي والدافعيـة للـتعلم، وربــط المعارف النظرية بالتطبيقات العملية لها، ولمـا كانـت مخرجـات الـتعلم تلــك مسن المتطلبـات الأسـاسية لطـلاب الاراسـات العليـا؛ لـا توجـ حاجـة ضـرورية لتنميـة الحضـور الاجتمـاعي والمعرفي، ممــا قـــ يسـهم فـي تطـوير تلـك المخرجـات لـى طلاب الدر اسـات العليـا بكليـة التربية. ولا شك أيضًا أن للضغوط الأكاديمية تأثير كبير

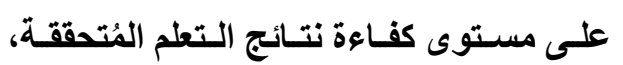
واهتمث عديد من الاراسـات بالبحث في تأثير الضـفوط الأكاديميـة على نتـائج التعلم، حيـث توجد علاقة سـببية بـين الضـغوط الأكاديميـة وتقــــير الـــذات والحضــــور الاجتمـــــــي

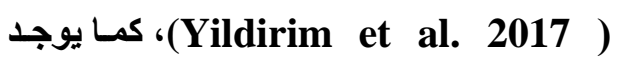
علاقـة بـين الضــوط الأكاديميــة ومسـتوى

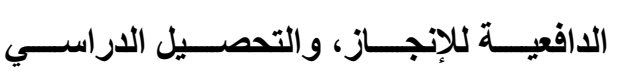
والدافعيـة نحسو التعلم \&araman \& Watson, 2017; Pascoe et al., 2020; Shorer \& Leibovich; 2020) الضـفوط الأكاديميـة تـؤثر سـلبًا على القدرات العقلية وعمليات التركيز والانتباه Perfect) .et al., 2016) وقد لاحظ الباحث من خـلال التدريس لطـلاب الاراسـات العليا في تخصصسي المنـاهج وطرق التدريس، وتقتيـات التعليم، وكذلك من خـلال

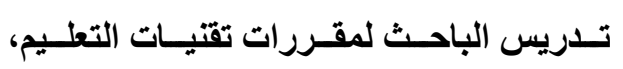

المؤشرات التي يمكن من خلاكها التبؤ بنجاح بيئات التتعلم عبر الإنترنت عامـة، ومجتمعـات الـتعلم القـائم علـى الاستقصــاء عبـر الويسب خاصـةة، وكـذلك التتبـؤ بمسـتوى التفــاعلات الاجتماعيـــة، والتشــــارك بــين المتعلمــين وبعضـهم، وبيـنهم وبـين المعــم، والتـي تـؤثر بدورها على الإنجاز الأكاديمي، وهذا مـا دفع عديـ من الباحثين إلى الكثف عن تأثير همـا وعلاقتهمـا بمخرجـات التعلم المختلفـة، ومنهـا (Akyol \& Garrison, 2008; دراسـات Joksimovic et al., 2015; Costley \& Lange, 2016; Kozan, 2016; Ma et al., 2020; Costley, 2019; Muljana ( \&uo, 2019) ، و التي أكلات أهمية تطوير الحضور الاجتماعي؛ لمـا لـه من تأثير إيجابي

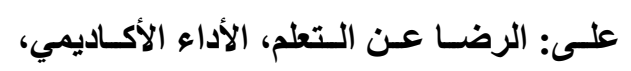

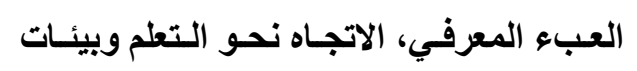

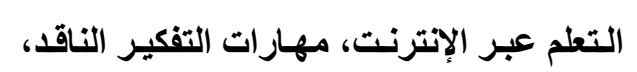

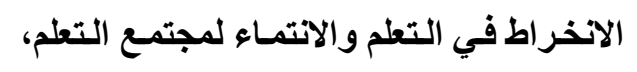

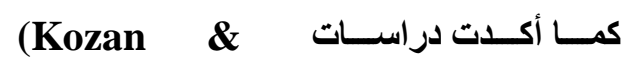
Richardson, 2014; Kozan , 2016; فuljana \& Luo, 2019) الحضور المعرفي في التنبؤ بالعبء المعرفي الاخيل والمرتبط، والرضا عن التعلم والإنجاز

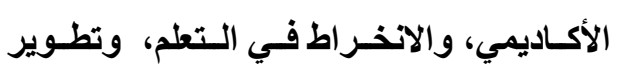

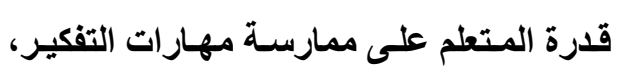

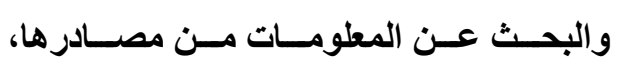
تكنولوجيا التعليـم ... . سلسلةدهراساتوبجوثمُحكَّة 
الجمعية المصرية لتكنولوجيا التهدليم

\section{الضغوط الأكاديمية لاى طلاب الدراسات العليا.}

- وجود تباين في نتائج الدراسـات بثـأن فاعلية

بيئـات التعلم عبر الإنترنت، ففي الوقت الذي

(Anderson, أكلت فيسه بعض الاراسـات

2017; Nolan-Grant, 2019; Zhang

et al., 2019; Zarzour et al., 2020)

فاعلية بيئات التعلم عبر الإنترنت؛ إلا أن هناك

Cعض الاراسـات

Hatmanto \& Protolo, 2020;

Bloomberg, 2020; Lee et al., 2020-b) بيئات التعلم عبر الإنترنت، من بينها: وجود تصورات سلبية لاى المعلمين والمتعلمين نحو لهو بيئـات الـتعلم عبـر الإتترنــت، حيـث يرونهـا صورة من بيئات التعلم التقليدية، لكن مدعومة بالتطبيقـات الرقميـة، ضــف عنصـر التـرابط الاجتماعي، وتفاعلات الأقران.

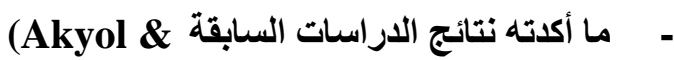

Garrison, 2008; Castle, 2014; Kilis \& Yildirim, 2016; Herayanti et al., 2020; Rohimin et al., 2020; Miller et al., 2020; Popescu \& ‘Badea, 2020; Yandra et al, 2021) بثـأن فاعليـة مجتمعـات الـتعلم القـائم على الاستقصاء عبر الويب في تحسين جوانب تعلم عدة من بينها: الحضور الاجتماعي والمعرفي،
والحاسـوب فـي التعليم فـي كليتـي التربيـة والعلوم والآداب، عدة جوانب تمثلت في: عدم اهتمــام الطـلاب بالتفاعـل مـع بعضـهم خـلال مســاحات التشـــارك ( المــدونات، الــويكي، الـرحلات المعرفيـة عبـر الويـب) التـي كانـت تُخصص لهم لأداء التكليفات، ضعف المعارف

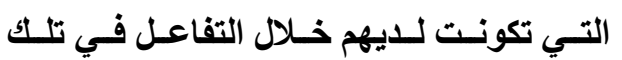
المســاحات، اهتمــاهم يتركـز فـي الجلســات الافتراضية مع الباحث، ضعف مستوى معالجة الأسئلة والرد عليها وعرض الآراء وتبريرها، ممـا دفع الباحث لمحاولة الكشف عن أسباب تدني مستويات الحضور الاجتماعي والمعرفي

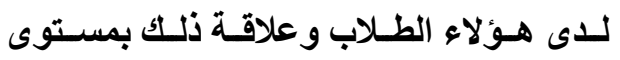
الإنجاز وتعاملهم مع الضغوط الأكاديمية.

وعلى ذلك توجد حاجـة ماسـة لتنمية الحضور الاجتمـاعي والمعرفي، حيث يُعدان من المتطلبـات الرئيسية لطلاب الدراسات العليا؛ لما لهما من تأثير إيجابي على المهارات المنطلبة في طالب الدراسـات العليـا، ومسن أهمهـا: رضــاه عـن التعلم، الدافعيـة والتحفيـز الــاتي، الانخـراط فـي الـتعلم والثــور بالانتماء لمجتمع التعلم، التشارك و التفاعل الايجـابي مع الآخرين، ممارسة مهارات التفكير والبحث عن المعلومات من مصادر ها المتنوعة.

ثـانيًا: الحاجـة إلــ اسـتخدام مجتمعـات الاستقصــاءع عبر الويب لتنميـة الحضـور الاجتمـاعى والمعرفي والإنجـاز الأكـاديمى وتطـوير مهـارات التعامـل مـع 
الجمعية المصرية لتكنـولوجيا التنعليم

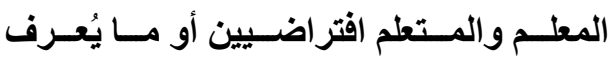

بالفضـاء المعرفي، وكذلك رؤيتهـا لأن التتعم

يحسدث مـن خـلال تشــارك وتفاعـل المــتملم

ومسؤوليته تجاه بناء مجتمع تعلمه \& Tao)

Zhang, 2018; Fiock, 2020; Rezaei

et al., 2020)

وبنـاءً عليـه توجد حاجـة لاسـتخدام مجتمعـات

التعلم القـائم على الاستقصـاء عبـر الويـب لتنميـة

الحضـور الاجتمـاعي والمعرفي والإتجـاز الأكـاديمي

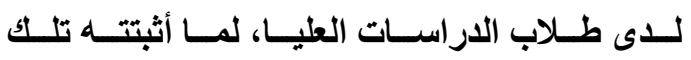

المجتمعسـات مسن فاعليـة فـي تحسـين الحضــور

الاجتمـاعي والمعرفي، التظظيم الـاتي والمهـارات

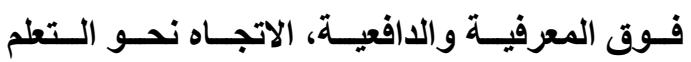
والإنجـاز الأكـاديمي، الكفـاءة الذاتيـة والانخراط في

التعلم، باعتبـار تلك المخرجـات التعليمبـة متطلبـات

رئيسية لطالب الاراسات العليا خلال مقرر نظم إدارة

$$
\text { التعلم الإلكتروني. }
$$

ثالثًا: الحاجة إلى الاستفادة من إستراتيجيات التتظيم الذاتى للتعلم فى تحسين فاعلية بيئسات التعلم عبر الويـبـ، بمــا يســهم فـى تنميـة الحضـور المعرفي والاجتمــاعي والإنجــاز الأكــاديمي، وتقليـل أثــار الضغوط الأكاديمية.

- تأكيد عديد من الاراسـات Zimmerman) \& Schunk, 2011; Lodge et al., ،2018; de la Fuente et al., 2020-a)
التنظـيم الـــاتي والمهـــار ات فـوق المعرفيـة

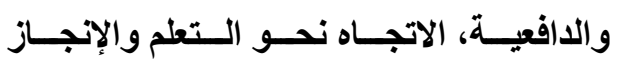
الأكـاديمي، الكفــاءة الذاتيــة والانخــراط فـي الـتعلم، ممسـا فـرض وجـود حاجـة لاسـتخدام مجتمعـات التعلم القـائم على الاستقصـاء عبر الويــب فــي تتميــة الحضـــور الاجتمـــــي والمعرفـي والإنجـاز الأكــاديمي لــى طـلاب الدر اسات العليا.

(Anderson, توصيات عديـ من الدراسـات 2017; Jimoyiannis \& Roussinos, 2017; Chen et al., 2017; Xing \& Gao, 2018; Hatmanto \& Pratolo, 2020; Goh, 2020; Popescu \&

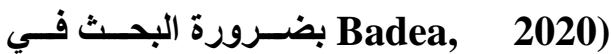
متغيرات تصميم بيئـات التعلم عبر الإنترنت،

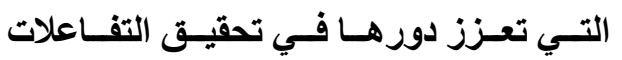
التعليمية والاجتماعية، لذا توجد حاجة للبحث في إسـتراتيجيات تعزيـز التفـاعلات التعليميـة والاجتماعيـة التـي يمكن تضـمينها في بيئات التعلم عبر الإنترنت لمعالجـة نـواحي القصور التـي سـبق الإثــارة لهـا، إضـافة إلسى حاجـة

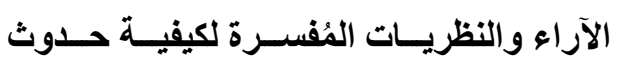
التتعلم وتتظيم التعليم إلى تـوفير مجتمعسات

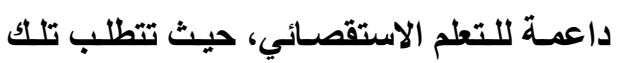
النظريـات ضـرورة تطـوير مجتمعـات تعلــم، تثظلب على مســافة البعد الناتجـة عـن كـون تكنولوجيا التعليـم ... . سلسلةدراساتوبجوثمُحطكمة 
الجمعية المصرية لتكنولوجيا التعليم

والكفـاءة الذاتيـة في التعامـل مـع بيئة التعلم، وإدارة وقت التعلم بثكل جيد، وتتظيم الجهود، وتخطيط الأهداف وتحديد معسيير التقييم في ضـوء الإمكانـات والقدرات، وبالتـالي تخفيـف أثثار الضغوط الأكاديمية. وجود تباين في نتائج الدراسـات بشـأن العلاقة بـين إســتراتيجيات التنظـيم الـــاتي للــتعلم وجوانب التعلم الأخرى، حيث أشـارت بعض (Basdogan, 2015; الدراســات Broadbent \& Poon, 2015; Nasseri \& Motallebzadeh, 2016; Altay \& Saracaloglu, 2017; Doo \&Bonk, 2020; Zheng, 2020) إيجـابي بـين مسـتوى اسـتخدام إسـتراتيجيات

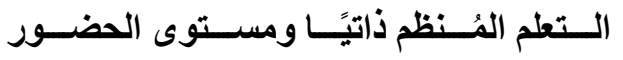
الاجتمـاعي في مجتمعـات التعلم الاستقصـائي عبر الويب، وجود ارتباط إيجابي بين استخدام استراتيجيات التنظيم الذاتي للتعلم والإنجـاز الأكاديمي، وجود تأثير إيجابي للتنظيم الذاتي للتعلم على الحضور الاجتماعي والمشاركة في مجتمعات التعلم عبر الإنترنت، الطلاب الذين يسـتخدمون مسـتويات أعلـى مـن مهــار اترات التنظيم الذاتي للتعلم، يظهرون مستويات أعلى في التفكير والمهارات فوق المعرفية، وقبول الاسـتخدام لمجتمعـات الـتعلم عبـر الإنترنــت، ويسأتي هــا عكس النتيجـة التـي توصـل لهـا
على فاعليـة التنظيم الذاتي للتعلم في التنبؤ بنجـاح المـتعلم في اسـتخدامه لاسـتراتيجيات التعامـل مـــع الضــفوط الأكاديميـة وتحقيـق الإنجـاز الأكـاديمي، وتحسين مستوى الكفـاءة الذاتيـة في التعلم بقدرة المتعلم على التظظيم الذاتي لتعلمـه، حيث إن معتقدات المتعلم عن كفاعته الذاتية وثقته بذاته، ترتبط بمهاراته في تخطبط تعلمـه ومراقبـة معدل تقدمسه وتقيسيم أدائه باستمرار وتصحيح مسار تعلمـه وتوجيـه جهوده نحو التعلم، توليد مستويات عالية من الا افعيـة والتحفيز الذاتي والتي تُعالج مشكلة بقـاء المتعلمـين لوقت طويـل خـلال مجتمعــات الاستقصـاء عبـر الإنترنـت، وهـذه المهـارات جميعها تُعد متطلبات لطالب الدراسات العليا. (Zenner et al., 2014; ما أكدته دراسـات Bedewy \& Gabriel, 2015; Vohs \& Baumeister, 2016; Kaunhoven \& Dorgee, 2017; Mcclelland et al., 2018 من وجود لعلاقة وثيقة بين مستوى مهـارات التنظيم الـذاتي للتعلم، والكفـاء في التعامـل مـعـع الضـغوط الأكاديميـة (مجموعـة المعسـارف والمهــارات المعرفيـة ومــاوراء المعرفيـة، والتصـورات، والمعتقــات، التــي يمكن للمتعلم استخذامها في مواجهة الضـغوط الأكاديمية وتقليل أثارها)، حيث يسهم التنظيم الـــاتي للـتـعلم فـي زيــادة الفعاليــة الذاتيـة، 
الجمعية المصرية لتكنـولوجيا التهليم

- أكد عديا من الدراسات على فاعلية مجتمعات

الـتعلم القـائم علـى الاستقصــاء عبـر الويـب

(Akyol \& Garrison, 2008; Kilis and Yildirim, 2018; Miller et al., 2020; Popescu and Badea, 2020; Herayanti et al., 2020; Rohimin et في al., 2020; Yandra et al., 2021) تحسين جوانب التعلم المختلفـة، وكذلك تأكيد عديد من الاراسـات على ضرورة البحث في

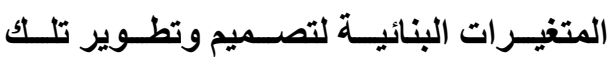
المجتمعـات، Nolan-Grant, 2019; Goh, 2020; Bloomberg, 2020; Fiock, 2020;

.Heilporn \& Lakhal, 2020) - بالر غم من تلك المميزات والفاعلية التعليميـة لمجتمعات الاستقصاء عبر الويب؛ إلا أن هنـاك تحديات عديدة ناتجة عن التداعيات والتحولات الرقميــة، وانتثـــار مجتمعــات الـتـعلم عبــر الإنترنـت ومـن بـين تلــك التحـديات: تتـوع المصـادر والمـوارد المتاحسة في بيــات التعلم عبر الإنترنت، حاجـة المتعلم إلى الاستقلالية والتحفيز الذاتي المستمر، الحاجـة لقدر كبير من الاستقلالية وتحمل مسؤولية التعلم، حاجة المــتملم للثــعور بالانتمــاء لمجتمــع الــتملم والنشـاط والإيجابية وتطوير المعتقدات بشـأن الفوائســ المتحققة مـن التعلم والقيمـة المُدركـة
Kizilcec et al. (2017) كيزلك وزملائسه (2017) حيث أثسارت نتائج الاراسـة إلى وجود تـأثير سـلبي لـبضض إســراتيجيات التظظـيم الــاتي للتعلم والإنجاز الأكاديمي، إضافة إلى توصيات (Kilis \& Yildirim, عديد من الدراسـات 2018; de la Fuente et al., 2020-a; Wong et al., 2020; Schumacher \& Ifenthaler, 2021) كيفــة تعزيـز إسـتراتيجيات التنظـيم الـذاتي

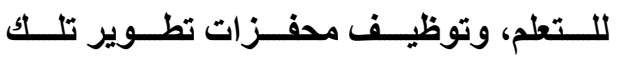
الإســــتراتيجيات فــــي مجتمعـــــات الــــتملم الاستقصائي عبر الإنترنت.

ويناءًً عليه توجد حاجـة لاستخدام إستراتيجية التظظيم الذاتي للتعلم في تنمية الحضور المعرفي، والاجتمـاعي، والإنجـاز الأكــاديمي، والتعامـل مـع الضغوط الأكاديمية لاى طلاب الدراسـات العليا بكلية التربيـة؛ لمـا لهذه الاسـتراتيجيات من تأثير إيجـابي في تحسـين مسـتوى الكفــاعة الذاتيـة لـى المـتعلم، وبالتالي تطوير مهار اته في تخطيط تعلمـه، ومراقبة معدل تقدمه، وتقييم أدائه باستمرار وتصحيح مسـار تعلمه، وتوجيه جهوده نحو التعلم، والتحفيز الأتي.

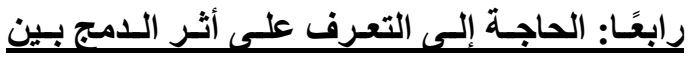
إســتر اتيجيتى التنظـيم الـذاتى للـتعلم ومجتمعسات الاستقصاء عبر الويب، في تنمية الحضور المعرفي و الاجتمــاعى والإنجـــاز الأكــاديمي، وتقليـلـ أثــار الضغوط الأكاديمية.

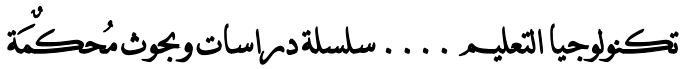


2020;de la Fuente et al., 2020-b;

Wong et al., 2020; Schumacher \&

Ifenthaler， 2021)

علاقة بين إستراتيجيات التنظيم الذاتي للتعلم

والتأثير الإيجابي لبيئات التعلم عبر الإنترنت،

كما أوصت بمزيد من البحث في كيفية تعزيز

استراتيجيات التنظيم الذاتي للتعلم، وتوظيف

محفـزات تطــوير تلـــك الاســتراتيجيات فــي

مجتمعات الاستقصاء عبر الإنترنت.

وبناءً عليه توجل حاجة للكثف عن أثر الدمج

بين إسـتراتيجية التنظيم الذاتي للتعلم ومجتمعـات

الاستقصـاء عبر الويـب، على الحضـور المعرفي،

والاجتمــاعي، والإنجــاز الأكساديمي، والتعامـل مـعـ

الضغوط الأكاديمية لدى طلاب الدراسات العليا بكلية

التربية؛؛ لمـا لهذه الإستراتيجيات مـن تأثثير إيجـابي

في تحسين مستوى الكفـاءة الذاتيـة للدى المـتعلم،

وبالتالي تطوير مهاراته في تخطيط تعلمه، ومراقبة

معدل تقدمه، وتقييم أدائه باستمرار وتصحيح مسـار

تعلمه، وتوجيه جهوده نحو التعلم، والتحفيز الذاتي،

كمـا توجد حاجـة لمعرفـة أنسب الظروف لممارسـة

استراتيجيات التنظيم الـذاتي للتعلم في مجتمعسات

التعلم القائم على الاستقصاء عبر الويب، من خلال

استخدام المحفزات المناسبة لتلك الإستراتيجيات.

في ضسو ومسا سـبق تأكد لـدى الباحث وجـود

حاجة للكثف عن أثر استراتيجية قائمة على الدمج

بين استر اتيجية التظظيم الذاتي للتطم ومجتمعـات
لـه، وللتعامـل مـع تلـك التحديات فإن المـتعلم

بحاجـة ضرورية لأن يكون قـادرًا على تنظيم

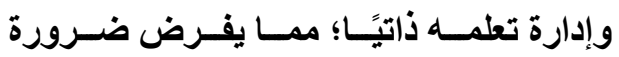
إكسابه مهارات تسـاعده على إدارة تعلمـه في تلـك البيئـات وتنظيم جهوده ووقته،، وكـنلك الاختيـار المناسب من بين المصـادر التعليمية المتنوعـة، وتحديــ الاسـتراتيجيات التعليميـة الملائمة له، لذا فبان الحاجـة تدعو للبحث في اســتراتيجيات تعزيــز فاعليـــة مجتمعــــات الاستقصـاء عبر الويـب، وإكسـاب المتعلمـين المهــارات التـي تمكــهم مـن التظلـب علـى مشكلات تنـوع البدائل والخيـارات والمصسادر التعليميـة، وكــلتك المشـكلات الناتجـة عـن فئن ارتفاع مستوى الاستقلالية في التعلم والتطور المسـتمر فـي أدوات وتطبيقــات الـتـلم عبـر الويـب، وقضـاء وقت أطسول في التتعلم عبر الإتترنـتـ، وامـتلاك المهـارات اللازمــة لإدارة (Chen et al., التعلم وتنظيم الوقت و الجها 2017; Tao \& Zhang, 2018; .Hatmanto \& Pratolo, 2020) تأكيد عديد من الدراسات على إمكانية استخدام إستراتيجيات التظظيم الذاتي للتعلم في التظلب على المشكلات والتّاعيات التي يمكن أن تؤثر سلبًا على فاعلية بيئات التعلم عبر الإنترنت، (Cho \& Shen, 2013; Kilis \& Yildirim, 2018; Min \& Nasir, 
الجمعية المصرية لتكنولوجيا التهليم

ا - ما معاييز تصميم استراتيجية قائمة على الامج

بــين إســتراتيجيتي التتظـــم الــذاتي للــتعلم

ومجتمعسات الاستقصــاء عبـر الويسب، علـى

الحضــور المعرفـي، والاجتمـاعي، والإنجـاز

الأكـاديمي، والتعامـل مـع الضـغوط الأكاديميـة

لاى طلاب الاراسات العليا بكلية التربية؟ ץ- مـا التصـميم التعليمـي لإسـتراتيجية مقترحـة قائمسة على الـدمج بين إسـتراتيجيتي التنظيم الـذاتي للـتعلم ومجتمعسات الاستقصـاء عبـر الويب، على الحضور المعرفي، والاجتمساعي، والإنجـاز الأكـاديمي، والتعامـل مـع الضـغوط الأكاديميـة لـدى طـلاب الار اسـات العليـا بكليـة الثربية؛ انج بـ مـا أثـر إسـتراتيجية قائمسة على الـدمج بـين إستراتيجيتي التظظيم الذاتي للتعلم ومجتمعات الاستقصــاء عبـر الويــب، علــى الحضــــر المعرفي، والاجتمـاعي، والإنجـاز الأكـاديمي، والتعامـل مـع الضـغوط الأكاديميـة لـدى طـلاب الاراسات العليا بكلية التربية؟ ع- ما أثر استراتيجية مقترحة قائمسة على الدمـج بــين إســتراتيجيتي التنظــيم الــذاتي للــتعلم ومجتمعـات الاستقصـاء عبـر الويسب، علـى الحضـور المعرفـي، والاجتمـاعي، والإنجـاز الأكـاديمي، والتعامـل مـع الضـغوط الأكاديميـة لاى طلاب الدراسات العليا بكلية التربية ترجع لتأثير مستوى التتظيم الذاتي للتعلم (مرتفع، منخفض) لايهمج
الاستقصساء عبـر الويـب، على الحضـور المعرفي، والاجتمـاعي، والإنجـاز الأكـاديمي، والتعامـل مـع الضغوط الأكاديمية لاى طلاب الدراسات العليا بكلية

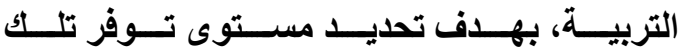
الإســتر اتيجيات مــن خــلال اســتخدام المحفـز الملائمسة، وعلاقـة ذلـك بتتميـة الحضـور المعرفي والاجتمــاعي والإتجــاز الأكــاديمي والتعامـل مــع الضغوط الأكاديمية لدى طلاب الاراسـات العليـا في كلية التربية، وعلى ذلك يمكن تحديد المشكلة في العبارة التقريريـة الآتيـة: "توجد حاجة إلى تصميم إسـتراتيجية قائمسة على الـدمج بـين إسـتراتيجيتي التنظيم الـاتي للتعلم ومجتمعسات الاستقصساء عبر الويسب، لتنميـة الحضـور المعرفي، والاجتمــاعي، والإنجاز الأكاديمي، والتعامل مع الضغوط الأكاديمية لاى طلاب الدراسـات العليا بكلية التربية". أسئلة البحث السؤال الرئيس للبحث: من أجل الوصول إلى حل هذه المشـكلة، تمكن الباحث مـن صـياغة السـؤال

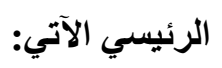

كيف يمكن تصميم إستراتيجية قائمة على الامج بين إسـتراتيجيتي التنظـيم الـذاتي للـتعلم ومجتمعـات الاستقصـاء عبر الويب، لتنميـة الحضور المعرفي،

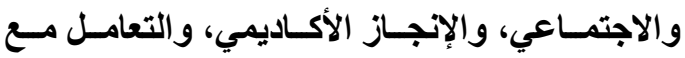
الضفوط الأكاديمية لدى طلاب الدراسات العليا بكلية التربية؟ ويتفرع من السؤال الرئيس الأسئلة الفرعية الآتية: تكنولوجيا التعليـ . . . سلسلةدراساتوبجوثمُحسكمة 
- تقــيم تصـور مقتـرح لإســراتيجية مقترحسة قائمسة على اللدمج بين إسـتراتيجيتي التنظيم الــاتي للـتعلم ومجتمعـات الاستقصــاء عبـر الويب، على الحضور المعرفي، والاجتمـاعي،

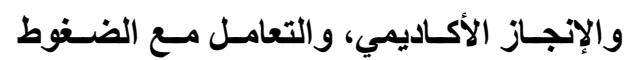
الأكاديميـة لـاى طلاب الدراســات العليـا بكليـة التربية. الكثـف عن فاعليـة اسـتراتيجية قائمسة على اللامج بين إستراتيجيتي التظيم الذاتي للتعلم ومجتمعسات الاستقصــاء عبـر الويـب، علـى إنى الحضـور المعرفي، والاجتمــاعي، والإنجــاز الأكساديمي، والتعامـل مـع الضـغوط الأكاديميـة لاى طلاب الار اسات العليا بكلية التربية. الكثـف عـن أثخر استراتيجية مقترحسة قائمسة على الدمج بين إستراتيجيتي التنظيم الذاتي

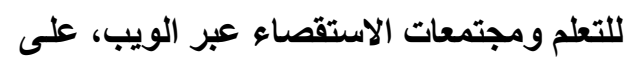
الحضـور المعرفـي، والاجتمــاعي، والإنجـاز الأكـاديمي، والتعامـل مـع الضـفوط الأكاديميـة لاى طلاب الدراسات العليا بكلية التربية ترجع لتأثير مستوى التنظيم الذاتي للتعلم (مرتفع، منخفض) لايهم. - عديد العلاقة بين مستوى الحضور (المعرفي، الاجتمـاعي) في مجتمعـات الاستقصـاء عبر

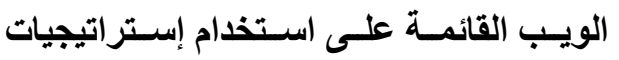
التنظـيم الـــاتي، وبـين الإنجسـاز الأكساديمي،

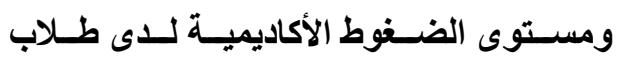
الدراسات العليا في كلية التربية.
هـ مـا العلاقة الارتباطيـة بين استراتيجية اللامج المقترحـة، والحضـور المعرفي والاجتمـاعي، لارئ

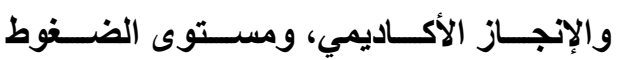
الأكاديمية لاى طلاب الاراسات العليا في كلية

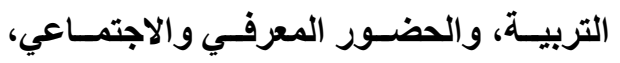
والإنجــاز الأكــاديمي، ومســتوى الضـــوط الأكاديمية لاى طلاب الاراسات العليا في كلية التربية؟ الاديمئه ד- مـا العلاقـة بيلن مستوى الحضـور (المعرفي، الاجتمـاعي) في مجتمعـات الاستقصـاء عبر لـر

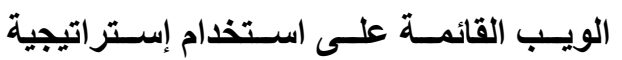
التنظـيم الــذاتي، وبـين الإنجـاز الأكساديمي،

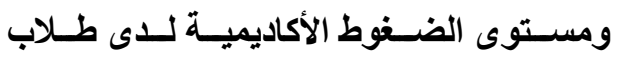
الاراسات العليا في كلية التربية؟

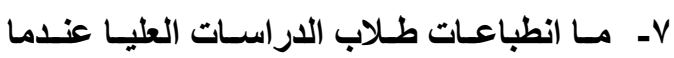
يواجهون ضـغوط أكاديميـة أثنـاء التتطلم عبر

$$
\text { الويب؟ }
$$

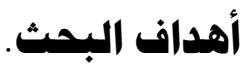

$$
\text { يهاف البحث إلى: }
$$

- تحديد معايير تصميم إستراتيجية قائمسة على الامج بين إستراتيجيتي التظيم الذاتي للتعلم ومجتمعـات الاستقصــاء عبـر الويـب، على الحضـور المعرفـي، والاجتمــاعي، والإنجـاز الأكـاديمي، والتعامـل مـع الضـفوط الأكاديميـة والية لاى طلاب الدراسات العليا بكلية التربية. 
الجمعية المصرية لتكنولوهيا التعليم

- المنهج الوصفي في مرحلة التحليل، وتضمنت الاطـلاع علـى الاراســات والأدبيـات الســابقة، وتحديــــ الاحتياجــات التعليميــة، وخصــائص المتعلمسين، والمـوارد والقيـود ومصــادر التـعلم المتاحســة، واشـــتقاق المعـــييز التصــميمية لإسـتراتيجية التعلم المُنظم ذاتيًا في مجتمعـات الاستقصــاء عبـر الويسب فـي ضـوء متطلبـات تطوير الحضور المعرفي والاجتمـاعي والإنجاز الأكاديمي، والتعامل مع الضغوط الأكاديمية. - منهج تظوير المنظومـات فقد استخدمه الباحث في مرحلة التصميم والتطوير، حيث تم تصميم وتطـوير متطلبــات تنفيــذ إسـتراتيجية الـتعلم المُـنظم ذاتيًا في مجتمعـات الاستقصـاء عبـر الويب.

- المـنهج التجريبـي فتم اسـتخدامه في مرحلة التطبيق والتقويم، حيث تطبيق تجربـة البحث الاســنطلاعية والأسـاسـية، ثــم تطبيـق أدوات القياس.

\section{التصسميشم التمريببي للبمث.}

يســتخدم البحــث التصــميم شـبة التجريبـي المعـروف بـنمط تصــميم المجموعـة الواحـدة ذو القياس القبلي البعدي.
- التعرف على انطباعـات طلاب الدراسـات العليا عندما يواجهون ضغوط أكاديمية أثناء التعلم عبر الويب.

\section{متغيرات البحث}

أـ المتغير المستقل: استراتيجية قائمسة على الـدمج بـين إسـتراتيجيتي التنظيم الذاتي

للتعلم ومجتمعات الاستقصاء عبر الويب.

$$
\begin{aligned}
& \text { ب- المتغير ات التابعة فتتمثل في: } \\
& \text { - } \\
& \text { - الحضور الاجتماعي. } \\
& \text { - الإنجاز الأكاديمي. } \\
& \text { - الضغوط الأكاديمية }
\end{aligned}
$$

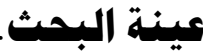

طلاب الدراسات العليا، المستوى الثاني/ السنة الأولى (مرحلة الماجستير) وهم يارسون مقرر نظم إدارة التعلم الإكتروني ضمن خطة برنامج ماجستير تقتيات التعليم و عددهم ( Y Y) طالبًا ذكور.

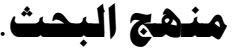

نظرًا لأن البحث الحـالي من البحوث التطويريـة في تكنولوجيا التعليم، فقد استخدام الباحث نموذج عبـد اللطيـف الجززار (2014) عمــ El-Gazzar كـا يلي: 
الجمعية المصرية لتكنولوبيا التعليم

\begin{tabular}{|c|c|c|}
\hline التطبيق البعدي لأدوات القياس & المعالجة التجريبية & التطبيق القبلي لأدوات القياس \\
\hline ا. . مقياس الحضور المعرفي والاجتماعي & إستراتيجية مقترحة قائمة & 1. مقياس الحضور المعرفي \\
\hline r. . مقياس التظيم الذاتي للتعلم & على الامج بين & و الاجتماعي \\
\hline r. مقياس الضغوط الأكاديمية & إستراتيجيتي التنظيم & r ·. مقياس التنظيم الذاتي للتعلم \\
\hline ع. استمارة رصد الإنجاز الأكاديمي في & الذاتي للتعلم ومجتمعات & r. مقياس الضغوط الأكاديمية \\
\hline مقرر نظم إدارة التعلم الإككتروني & الاستقصاء عبر الويب & \\
\hline
\end{tabular}

شكل (1)

$$
\text { التصميم التجريبي للبحث }
$$

درجات الإنجاز الأكاديمي للدى طلاب الدراسـات

$$
\text { العليا في كلية التربية. }
$$

r- ت توجد فروق دالـة إحصـائيًا عند مستوى دلالـة

فروض البحث.

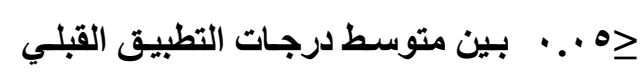

والبعدي لمقيساس الضـغوط الأكاديميـة في بيئة

التعلم عبر الويب لدى طلاب الدراسـات العليـا

$$
\text { في كلية التربية. }
$$

عـ - توجد فروق دالـة إحصـائيًا عند مستوى دلالـة

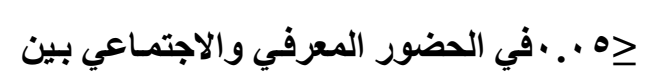

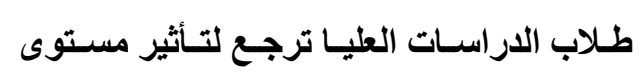

التنظيم الذاتي للتعلم (مرتفع، منخفض) لايهم.

هـ توجد فروق دالـة إحصـائيًا عند مستوى دلالـة

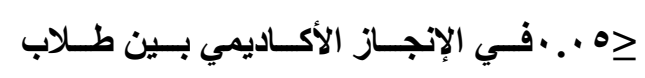

الدراسـات العليـا ترجع لتـأثير مستوى التنظيم

$$
\text { الأتي للتعلم (مرتفع، منخفض) لايهم. }
$$

للإجابـة على أسـئلة البحـث تـم صـياغة الفـروض روض

أ- الفروض المتعلقة بفاعلية إستراتيجية الدمج

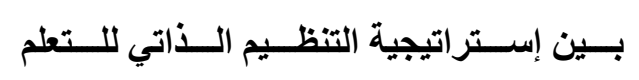

ومجتمعات الاستقصاء عبر الويب، في تنمية

الحضــور المعرفـي والاجتمــاعي، والإنجــاز

الأكاديمي، ومستوى الضـوط الأكاديميـة لدى

طلاب الاراسات العليا في كلية التربية:

ا - توجد فروق دالـة إحصـائيًا عند مستوى دلالــة

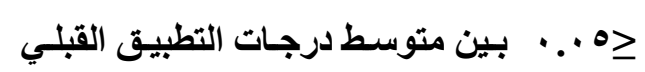

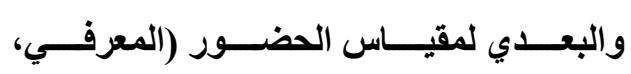

الاجتماعي) لدى طلاب الدراسات العليا في كلية

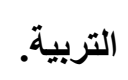

r- ت توجد فروق دالـة إحصـائيًا عند مستوى دلالـة

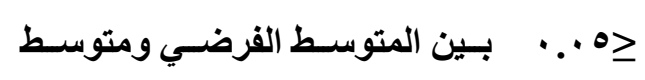


الجمعية المصرية لتكنولوجيا التعليم

الضغوط الأكاديمية لدى طلاب الدراسـات العليا

$$
\text { في كلية التربية. }
$$

• ا-يوجد ارتبـاط دال إحصـائيًا عنـــ مستوى دلالـة

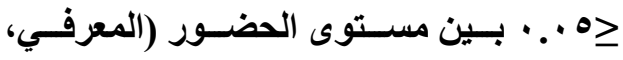
الاجتمــاعي)، والإنجـاز الأكساديمي، ومسـتوى الضغوط الأكاديمية لدى طلاب الدراسـات العليا

$$
\text { في كلية التربية. }
$$

\section{هدود البحث.}

يلتزم البحث بالحدود البشرية المتمثلة في طلاب الار اســات العليـا في كليـة التربيـة الـذين يدرسـون مقــرر نظــم إدارة الــتعلم الإلكترونــي، والحسـدود الموضوعية وتتمثل في المهام والتكليفـات المرتبطة بموضوعات مقرر نظم إدارة التعلم الإكترونـي، أمسا الحدود الزمانية فتتمثل في الفصل الدراسي الثاني

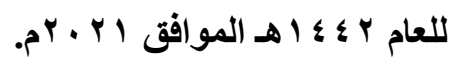

\section{المعالجات التجريبية في البحث.}

تتمثـل المعالجـة التجريبيـة فـي الإسـتراتيجية

القائمسة على اللدمج بين إستراتيجية التنظيم الذاتي

للتعلم ومجتمعات الاستقصاء عبر الويب، في ضوء متطلبـات تنميـة الحضـور المعرفي والاجتمــاعي، وتحسين الإنجـاز الأكـاديمي، والتعامل مـع الضـغوط الأكاديمية لطلاب الاراسات العليا بكلية التربية.
צ- توجد فروق دالـة إحصـائيًا عند مستوى دلالـة \. . . • في مسـتوى الضـنوط الأكاديميسة بين طـلاب الاراســات العليـا ترجـع لتـأثير مسـتوى التنظيم الذاتي للتعلم (مرتفع، منذفض) لديهم. بـ الفـروض المتعلقــة بالعلاقــة الارتباطيـة بـين الإسـتراتيجية المقترحسة، والحضسور المعرفي والاجتمــاعي، والإنجـاز الأكـاديمي، ومسـتوى الضغوط الأكاديمية لاى طلاب الاراسـات العليا في كلية التربية: V- توجـــ علاقــة ارتباطيـة دالــة إحصــائيًا عنــــ

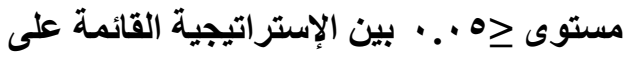
دمــجع إســتراتيجية التظظـيم الـــاتي للــتعلم ومجتمعات الاستقصـاء عبر الويب، والحضور المعرفي والاجتمــاعي لـلـى طـلاب الدراسـات العليا في كلية التربية.

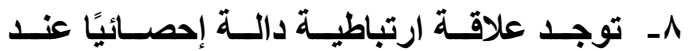
مستوى \ه . . • بين الإستراتيجية القائمة على دمــج إســتراتيجية التنظـيم الـــاتي للــتعلم ومجتمعـات الاستقصـاء عبر الويب، والاتجـاز الأكاديمي لاى طلاب الدراسـات العليا في كلية التربية. 9- توجـــ علاقــة ارتباطيـة دالــة إحصـائيًا عنـــ

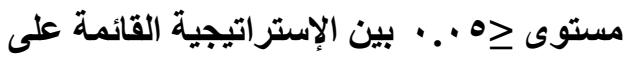
دمــج إســتراتيجية التنظــيم الـــاتي للــتعلم ومجتمعـات الاستقصـاء عبر الويب، ومستوى

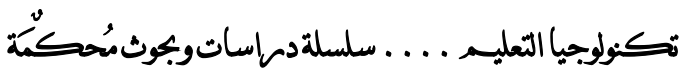


للـتعلم فــي بيئسات الإنترنــت عامــة ومجتمعسـات الاستقصاء عبر الويب خاصة. بـ الأهميـة التطبيقيـة، تتمثـل في: الاسـتفادة مـن نمــاذج الأدوات أو التطبيقــات المســتخدمة ضــمن مجتمع التعلم القـائم على الاستقصـاء عبر الويب، وإستراتيجيات التظيم الذاتي التي يمكن توظيفها لتعزيز فاعلية تلك المجتمعات، الاستفادة من أدوات البحث والتي تثمل: مقياس التنظيم الأتي للتعلم في بيئات التعلم عبر الويب، مقياس الحضور المعرفي الاجتمـاعي ومقيـاس الضـغوط الأكاديميـة في بيئات التعلم عبر الويب، الاستفادة من قائمة المعايير التي تم إعدادها عند تطوير إستراتيجيات التنظيم الذاتي للتتطم في مجتمعسات الاستقصساء عبر الويب في مراحـل عمريسة أخـرى ولمجــالات تعلــم أخـرى، الاستفادة من إستراتيجيات التظيم الذاتي للتعلم في مجتمع الاستقصاء عبر الويب في البحث الحالي في تدريس المقررات الاراسية.

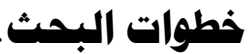

في ضوء هدف البحث المتمثل في" الكثف عن أثر استراتيجية قائمة على الدمج بين إستراتيجيتي التنظيم الذاتي للتعلم ومجتمعـات الاستقصـاء عبر الويـب، عــى الحضــور المعرفـي، والاجتـــــي، والإنجاز الأكاديمي، والتعامل مع الضغوط الأكاديمية خلال مقرر نظم إدارة التعلم الإكترونسي للاى طلاب الار اســات العليـا في كليـة التربيـة، وللإجابـة على العى

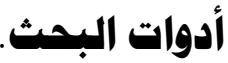

1- مقيــاس الحضــور (المعرفـي، الاجتمــاعي)

لطلاب الدراسات العليا.

r- مقيـاس التنظيم الـذاتي للتعلم في مجتمعـات

الاستقصاء عبر الويب

r- مقيـاس الضـغوط الأكاديميـة في بيئسات التعلم

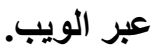
ع- استمارة تقدير الإتجاز العام للطالب في المقرر بلالة (الاختبارات الفصلية، الاختبار العملي، المهام والتكليفات، الاختبار النهائي للمقرر).

أهميهة البحث. قد يسهم هذا البحث في: أـ الأهمية النظرية، وتتمثل في: إلقاء الضوء على المعـيير التصميمة بين الإستراتيجية القائمـة على الـدمج بـين إسـتراتيجيتي التنظيم الـذاتي للـتعلم ومجتمعـات الاستقصــاء عبـر الويـب، في ضـوء متطلبـات تنميـة العضـور المعرفـي والاجتمـاعي، وتحسـين الإنجـاز الأكــاديمي، وتطـوير مهــارات التعامـل مــع الضــوط الأكاديميـة، وتطـوير وعـي

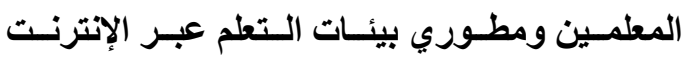

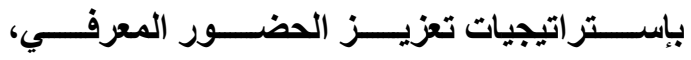
والاجتمساعي، فهم العو امـل والمحددات التـي تؤثر على فاعلية مجتمعات التعلم القائم على الاستقصساء عبـر الويـب، إدراك إســتراتيجيات التنظـيم الـذاتي 
الجمعية المصرية لتكنولوهيا التعليم

خلال مقرر نظم إدارة التعلم الإلكترونـي لدى

طلاب الدراسات العليا في كلية التربية.

ץ_rr: التصـميم التعليمسي لإسـتراتيجية الـدمج

بـين إســتراتيجيتي التنظــيم الــذاتي للــتعلم

ومجتمعـات الاستقصــاء عبـر الويسب، علــى

الحضـور المعرفـي، والاجتمــاعي، والإنجـاز

الأكـاديمي، والتعامـل مـع الضـغوط الأكاديميـة خلال مقرر نظم إدارة التعلم الإلكترونـي لدى طـلاب الدراسـات العليـا في كليـة التربيـة، في ضـوو خطـوات التصــميم التعليمـي لنمـوذج

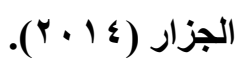

$$
\text { ع - تصميم أدوات البحث. }
$$$$
\text { هـ تجربة البحث. }
$$

דـ التحليل الإحصائي للبيانات.

V- عرض نتائج البحث ومناقثتها وتفسيرها.

^ـ تقديم التوصيات والمقترحات المناسبة.

\section{ومساتحات البمث}

يعرض البحث الحـالي للمفـاهيم الإجرائية التي

تم استخدامها في ضوء طبيعة البحث وأهدافه على يلى

$$
\text { النحو الآتي: }
$$

- مجتمـع التتعلم القـائم علـى الاستقصـاء عبـر

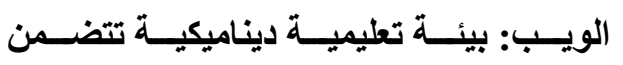

مجموعـة مـن عمليـات التثــارك، والتفاعـل،

والتأمل في التعلم، والمهـارات فوق المعرفية،

I Ho
تسـاؤلات البحث والتحقق من صسة فروضـة تسير خطوات البحث كما يلي:

ا ـ الاطلاع على الاراسـات والأدبيات السـابقة ذات

العلاقـة بـالمتغير ات المسـتقلة والتابعـة فـي

$$
\text { البحث. }
$$

r- اشــتقاق المعــاييز التصــميمة للاســتراتيجية

القائمسة على اللدمج بين إستراتيجيتي التنظيم

الـذاتي للـتملم ومجتمعسات الاستقصــاء عبـر

الويب، على الحضور المعرفي، والاجتمـاعي،

والإتجـاز الأكـاديمي، والتعامـل مـع الضـغوط

الأكاديميــة خــلال مقــرر نظـــم إدارة الــتعلم

الإلكتروني لاى طلاب الدراسات العليا في كلية

التربية.

r- تصميم المعالجة التجريبية (إستراتيجية قائمسة على اللدمج بين إسـتراتيجيتي التنظيم الذاتي للتعلم ومجتمعات الاستقصاء عبر الويب، على الحضــور المعرفـي، والاجتمـاعي، والإنجـاز الأكـاديمي، والتعامـل مـع الضـغوط الأكاديميـة خـلال مقرر نظم إدارة التعلم الإلكترونسي لدى طلاب الاراسات العليا في كلية التربية) مرورًا

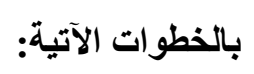

ا_"r: إعداد التصور المفـاهيمي لإسـتراتيجية الامج بين إستراتيجيتي التظيم الذاتي للتعلم ومجتمعـات الاستقصـاء عبـر الويسب، علـى الحضـور المعرفـي، والاجتمـاعي، والإنجـاز الأكـاديمي، والتعامـل مـع الضـغوط الأكاديميـة تصكولوجيا التعليـم . . . . سلسلةدماساتوبجوثمُحصِمة 
الجمعية المصرية لتكنولوجيا التهليم

عـن المعلومــات، والفاعليـة فــي تخطـيط الأهــاف، واختبـار الإسـتراتيجيات الملائمــة

لتحقيقها.

- الحضــور الاجتمــاعي: عبـارة عـن مسـتوى مهارات المتعلم في التعبير عن ذاته، وتعزيز الترابط الاجتماعي بينهله وبين أقرانـه والمعلم، واسـتخدام التلميحـات الاجتماعيـة، وإجـراء الحوارات الهادفة، والتعبير عن رأيسه، وإبراز نقــاط تميـزه، واسـتخدام أســاليب التواصـل المتزامنة وغير المتزامنة. الإنجـاز الأكـاديمي: مجــوع الــدرجات التـي حصل عليها طالب الدراسـات العليا في جميع المهـام التقييميـة ذات العلاقـة بـالمقرر مُقاســة بالاختبـارات الفصلية، والنهائية، و التكليفـات،

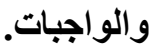
- الضغوط الأكاديمية: عبارة عن الحالة العقلية أو العاطفيـة أوكليهيــا التـي يثـعر بهـا طالب الاراســات العليـا أثنـــاء التفــاعلات التعليميـة والاجتماعيـة في مجتمعسات الاستقصـاء عبر الويب، والمرتبطة بالأعباء الناتجـة عن تنفيذ

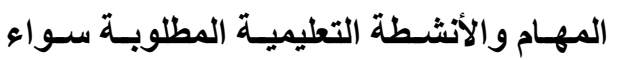

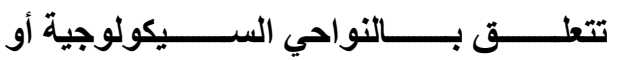

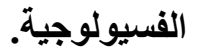

\section{الإطار النظري للبحث}

نظرًا لأن البحث يهـدف إلى الكثـف عن أثر اسـتراتيجية قائمسة على الـدمج بـين إسـتراتيجيتي
لتعزيــز الحضــور المعرفـي، والاجتمــاعي، وصولاً لبناء التعلم وتحقيق أهدافه. التنظيم الذاتي للتعلم: عملية بنائية يقوم فيها طالب الدراسات العليا بتحديد توقعاتهـ وتخطيط أهدافـه، وتنظـيم ومراقبـة وتوجيـه الــاوفع والسـلوكيات المرتبطـة بتفاعلاتـه الاجتماعيـة والتعليميـة فـي مجتمعسـات الاستقصــاء عبـر الويب، وصولَا لتحقيق التعلم المطلوب. - استراتيجية التنظيم الذاتي للتعلم: عبـارة عن سلســلة الإجــراءات التـــي يقـوم بهــا طالـب الار اسـات العليـا لتوجيـه معارفـه ومهاراتـه، وتنثــيط ومر اقبـة دو افعـه وسـلوكياته نحسو التعلم، وتقيـيم أداءه لإنجـاز المهـام التعليميـة المطلوبة. - استراتيجية الـامج بين إستراتيجيتي التنظيم الـــاتي للـتعلم ومجتمعسات الاستقصــاء عبـر الويسب: مجموعـة مـن عمليـات التثــــك،

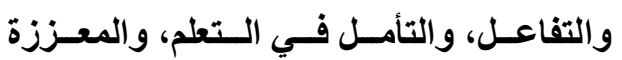
بسلسلة من الإجراعات التي يقوم بها طالب الار اسـات العليـا لتوجيـه معارفـه ومهاراتـه، وتنشـيط ومراقبـة دو افعـه وسـلوكياته نحسو التعلم، وتقيـيم أداءه لإنجـاز المهـام التعليميـة المرتبطة بمقرر نظم إدارة التعلم الإكتروني. - الحضــور المعرفـي: عبــارة عـن مسـتوى مشــاركة المـتعلم فـي بنــاء مجتمـع الـتـعلم، والتشارك في المحتوى، وطرح الاستفسـارات ذات المعنى، وتبريـر وجهات النظر، والبحث 
الجمعية المصرية لتكنولوجيا التهليم

- مفهـوم مجتمعـات الاستقصــاء عبـر الويـبب

وتوجهاتها النظرية.

تحظى مجتمعات التعلم القائم على الاستقصـاء

عبر الويب، باهتمام يتزايد يومًا بعد يوم، نتيجة عدد مــن العوامـلـل مــن بينهــا: التحــول نحــو الــتعلم الإكتروني، والتوسع في استخدام بيئسات التعلم عبر الإنترنت، وزيادة الاقبال على التعلم عبر الإنترنت، لمواجهة التحديات والأخطار التي قد تصساحب التعلم الحضـوري، التطور الكبير في التطبيقـات الرقميـة والذي ترتب عليـه انتثـار التعلم الرقمـي، الحاجـة لتوظيف مضـامين وتطبيقات نظريـات التعلم، والتي غيرت بطبيعتها النظرة إلى التعلم والتعليم وكيفيـة

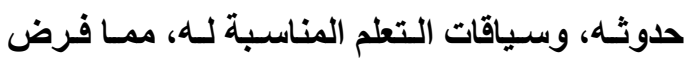
التحـول والحاجـة لمزيــــــن البحـوث التـي تتـــاول تطوير مجتمعسات التعلم الاستقصسائي عبر الويب،

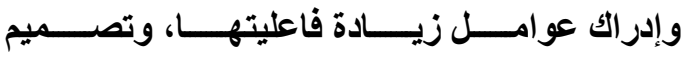
إستراتيجيات إدارة مكوناتها.

ونتيجــة للاهتمــام المتزايـــ بمجتمعـات الـتعلم القائم على الاستقصاء عبر الويب، لذا تتاولت بعض الآراء المفـاهيم المرتبطـة بـه في صسور متتوعـة، حيـث عرفـه البعض بأنـه مجموعـة العمليـات التي تعتمــ على الاستكثـاف المستمر للمعسارف، والتي تُسـهم في انخراط المتعلم في التعلم Suarez et) (al., 2018) ملائم لإدراك ومعالجة متغيرات التعلم عبر الإنترنت وما يرتبط بها من تفاعلات تعليمية واجتماعيـة، بمـا
التظظيم الذاتي للتعلم ومجتمعسات الاستقصساء عبر الويسب، علــى الحضــور المعرفـي، والاجتمــاعي، والإنجاز الأكاديمي، والتعامل مع الضغوط الأكاديمية خلال مقرر نظم إدارة التعلم الإكتروني لدى طلاب الار اسـات العليـا في كليـة التربيـة، لـذا فـإن الإطسار النظـري يتنـاول المحساور الآتبـة: المحسور الأول: مجتمعات التعلم القائم على الاستقصـاء عبر الويب، المحور الثاني: التظظيم الذاتي للتعلم في مجتمعات الاستقصـاء عبر الويـب، المحور الثالث: الحضـور المعرفي والاجتمـاعي وعلاقتهمـا بمخرجـات التعلم، المحـور الرابـع: الضـفوط الأكاديميـة في مجتمعـات التعلم عبر الإنترنت، المحور الخـامس: الدمج بين إســتراتيجيتي التظظـيم الــذاتي للـتـملم ومجتمعسات الاستقصساء عبر الويب، المحور السـادس: العلاقة بـين متغيـرات البحـث، المحسور الســابع: التصـور المفـاهيمي لإســتراتيجية الـتعلم المُــنم ذاتيــا في مجتمعات الاستقصاء عبر الويب في البحث الحالي. وفيما يلي تناول كل محور من تلك المحاور تفصيلً: المحور الأول: مجثمعـات التعم القـائم على الاستثصاء عبر الويب. يتضـمن هذا المحـور عددًا مـن العناصـر هـى: المفهوم، التوجهـات النظريـة، الفاعليـة التعليميـة، المكونـات، اعتبـار ات ومراحل تصميم وتطوير تلك المجتمعـات، أدوات وتطبيقات بنـاء مجتمعـات التعلم القائم على الاستقصاء عبر الويب. تصكنولوجيا التعليـم . . . . سلسلةدماساتوبجوثمُححكمة 
الجمعية المصرية التكنولوجيا التعليم

والمعلمين في بيئسة التتطلم عبر الإنترنـت، وتفسـر

حدوث التـعلم في ضـوء ثـلاث مكونــات: التفاعـل المعرفي أو الإدراكي، التفاعل الاجتمـاعي، التفاعل التعليمي، وفي ضوء تلكك الفلسفة طور جرشيون وزميلاه (2001) (Garrison et al.) إطار لفهم طبيعة مجتمعـات الاستقصـاء عبر الإنترنت أطلقوا عليـهـ الإطــار المفــاهيمي لمجتمعــات الاستقصــاء Community Inquiry Learning Framework Community نظريـة مجتمعـات الاستقصــاء Inquiry Theory ، وفي الحالتين فإن الاهتمـام مشترك وهو تفسير التفاعل الذي يـتم في بيئـات التعلم عبر الإنترنت، حيث يهتم هذا الإطار أو تلك النظريـة بتقــيم الإرشــادات اللازمـة بثـأن الكيفيـة والاسـتراتيجيات التـي يسـتخدمها المـتعلم للتفاعل والتشارك، وأن المتعلم في ضوء هذا الإطـار بحاجـة إلسى الحضــور المعرفـي والاجتمـــي والتعليهـي، ومجتمعات التعلم الاستقصائي ليست بجديدة؛ حيث

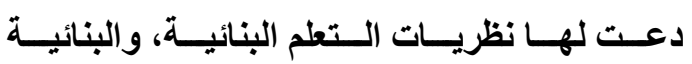
الاجتماعيـة، والتي فسرت التعلم بأنـه نـاتج حدوث التفاعل والتشارك التعليمي. - الفاعلية التعليمية لمجتمعات الاستقصـاء عبر

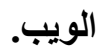

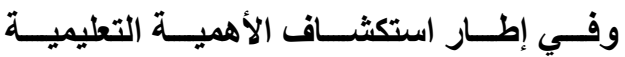
والفاعليـة لمجتمعـات الـتعلم الاستقصـائي، أطلــع الباحث على بعض الار اسـات ذات العلاقةة، ومن ثم
يعزز التعـاون والتثـارك بين المتعلمين وبعضـهم، ومع المعلم (Yandra et al., 2021)، كما يعرف بأنسه مجموعـة مـن الأنثـطة الاستقصـائية عبـر الإتترنـــت تعتمــد علــى التثـــارك وتبــادل الأفكـار واجهات النظر وتحمل مسؤولية التطلم Chen et)

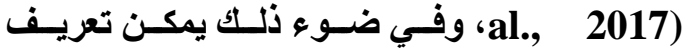
مجتمعات التعلم القائم على الاستقصساء عبر الويب بأنهـ بيئة تعليميـة ديناميكيـة تتضمن مجموعـة من عمليـات التثــارك، والتفاعل، والتأمسل فـي التتطلم، والمهــارات فـوق المعرفيـة، التـي تُنـــ مـن خـلال مجموعـــة مـــن الإســـتراتيجيات الاستقصـــائية الاجتماعية، لتعزيز الحضور المعرفي، والاجتماعي، وصـولَا لبنـاء التتعلم وتحقيـق أهدافـه، أمسا نمـوذج مجتمع التعلم القائم على الاستقصاء عبر الويب فهو عبارة عن إطار مفاهيمي يتضمن إرشادات التصميم التعليمي لأنثطة التعلم الاستقصائي عبر الإنترنت، واستخدام مجموعة من الاستراتيجيات التي تهيئ للمتعلم فرص التفاعل والتشـارك، لتعزيز حضوره المعرفـي والاجتمـاعي، فـي إطـار فاعليـة المـتعلم والاعتماد الايجابي المتبادل. وتتطلق فلسـفة التعلم القـائم على الاستقصــاء عبر الويـب مـن مضسامين مجموعـة مـن النظريـات

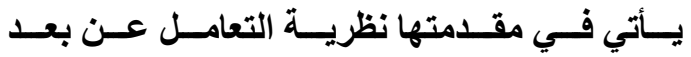
Transactional Distance Theory (TDT) التـي طورهـا مايكل مـور Moor، حيـث أفترض وجـود مســاحة فضــاء معرفـي بـين المتعلمـين 
الجمعية المصرية لتكنـولوجيا التنعليم

- إتاحة فرصة التتظيم الذاتي للتعلم، ومسـاحات

لتحريـر وتثــارك المحتوى، وكذلك مسـاحات

(Jimoyiannis \& Roussinos, للمناقشـات

- ت تحســن مهـــار ات التأمــلـل الــذاتي، والــتعلم

التشـاركي، والتعلم بـالفريق، وكذلك مهار ات

(Herayanti et al., لـ المشـكلات

تحقيـق المرونـة في التفكير، والنقــ الـذاتي،

وتقـــير الـــات، وعـرض وجهـــات النظـــر

(Hatmanto \& Pratolo, وتبريزهـا

- تطوير مهار ات استخدام التطبيقات ذات العلاقة بالتشــارك، والتواصـل، واسـتخدام المحتـوى

الرقمي، واستراتيجيات تصميم وتتفيذ الأنثطة

الاستقصائية (Fiock, 2020).

وفي ضـوع نظريـة الـتعلم الاستقصـائي عبـر

الإنترنتـ؛ فـإن مجتمـع التعلم الاستقصـائي يُعد بيــة تعليميـة تفاعلية، تتكون من ثُلاث مكونـات رئيسية هـى: الحضــور المعرفـي أو الإدراكـي، الحضــور

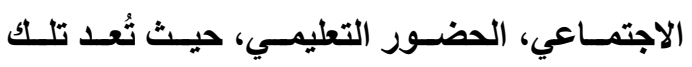
الأنــواع مــن الحضــور، عناصــر لبنيــة مجتمــع الاستقصـاء عبر الإنترنـت، وفى الوقت ذاتـه هدفًا لمجتمعات التعلم الاستقصـائي عبر الإنترنت، حيث أشـارت بعض الاراسـات إلى أن تلك الأنواع الثثلاث هـى بمثابــة المكونـات الرئيسـية لمجتمـع الـتعلم
تلخيص فاعليـة مجتمعـات التتعم الاستقصسائي في

النقاط الأتية:

- يعمل على تحسين اتجاهـات المتعلمين نحسو

بيأسـات الــتعلم، والاســتر اتيجيات المُضــــنة

خلالهـــا، والأثـــة التعليميــة الاستقصــائية

.(Kumi-Yeboah., 2018)

- تزويد مطوري بيئات التعلم عبر الإنترنت بفهم

واضــح لأنمــاط تشــارك وتفاعـل المتعلمـين

والعوامل التي تـؤثر في فاعليتهـا -Nolan)

.Grant, 2019)

- التنبؤ بمستوى رضا المتعلمين عن التعلم عبر

الإنترنـت وتحسـين مسـتوى الكفــاءة الذاتيـة

للمــتمطلم، وكـــللك تحســين جـــودة الـــتعلم

.(Yandra et al., 2021)

تحسين رضـا واتجـاه المعلمين وأعضساء هيئة التـدريس عـن بيأسـات التتعلم عبـر الإنترنـت وتطوير مهـار اتهم المرتبطة بتظظيم وتصـميم

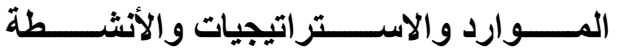

الاستقصائية (Lee et al., 2020-b). تحسين جودة المحتوى، والدافعية نحو التعلم، والقابليـة للاسـتخدام، وتحسين الانخـر اط في التعلم، وتحمل المسؤولية، وإدارة المجموعات

.(Tao \& Zhang, 2018) - تحسـين الإنجـاز الأكـاديمي، وتطـوير النمـو المهزتـي، وتعزيــز الالتــزام نــــو التفــاعلات والتشـارك في مجتمعات التعلم \&ing ) .Gao, 2018) 
وفي ضوء مـا سبق تتضـح حاجـة المؤسسـات التعليميـة وجميع عناصر المنظومسة التعليميـة إلى البحث في إستراتيجيات تعزيز الأنـواع التثلاث مـن الحضـور؛ بـل وأوصـت بعض الدراسـات بضـرورة إضـافة مكــون رابـع لمجتمعسات الاستقصــاء عبـر الإنترنـت، وهـو حضـور المـتعلم، والـــي يـرتبط بالفاعلية الذاتية للمتعلم وسيطرته على التعلم، ممـا (Anderson, يـؤدي إلـى انخراطـه فـي الـتعلم 2017; Kumi-Yeboah., 2018) ضرورة دراسة العلاقة التفاعلية بين أنواع الحضور الثلاث، ومخرجات التعلم، وأهدافـه المتوقعة، وفيمـا يلي تناول مكونات مجتمعات التعلم الاستقصائي عبر الإنترنت بمزيد من التفصيل:

Cognitive أ- الحضور المعرفي (الإدراكي)

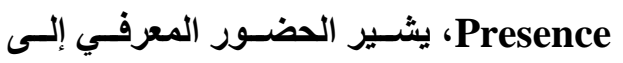
مسـتوى مشــاركة المـتطلم فـي بنـاء مجتمـع الــتعلم، والتثـــارك فــي المحتـوى، وطــرح الاستففسـارات ذات المعنس، وتبريـر وجهـات النظر، والبحث عن المعلومـات، والفاعلية في تخطـيط الأهــاف، واختيـار الاســتراتيجيات الملائمـة لتحقيقها، ويرتبط الحضور المعرفي

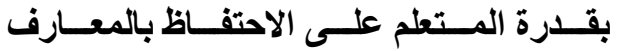
والمفاهيم المرتبطة بموضوع التعلم، وقدرته على تطبيقها في سياقات تعلم جديدة، ويُستدل على الحضور المعرفي للى المتعلم من خلال
الاستقصـائي عبـر الإنترنـت Hatmanto \& Pratolo, 2020; Anderson, 2017; Nolan. Grant, 2019; Heilporn \& Lakhal, 2020) وأكلات عديد من الدراسات على أهمية تطوير الحضــور المعرفــي، والاجتمـــاعي، والتعليمــي (Popescu \& Badea, 2020; Hatmanto ‘\& Protlo, 2020; Yandra et al., 2021) حيث توصلت نتائج تلك الدراسات إلى إن مجتمعات التعلم الاستقصائي عبر الإتترنت، توفر المسـاحات الكافيـة للمتعلم سـواء للتثـارك في بنـاء المعـارف والتعلم (حضور معرفي)، أو النقاش وتبادل الآراء ووجهــات النظـر وطـرح الأســلة وتقيـيم الآراء، والتعبير عن الذات (حضور اجتماعي)، والمشـاركة فـي تخطـيط الأهــافـ ومهــام الـتـطم والأنثــطة الاستقصـــائية، وتنظـــيم وتسلســلـل الإجـــراءات والعمليات، واختيار إستراتيجيات التنفيذ (حضور تعليمي)، وفي الوقت ذاته أثـارت بعض الاراسـات إلسى أن هنــاك ارتبـاط بـين مسـتوى تـوفر أنـواع الحضور الثُلاث في مجتمع التعلم الاستقصسائي عبر الإنترنت، والإنجاز الأكـاديمي للمتعلمين، ورضـاهم عـن الـتـطلم، وجـودة الـتـعلم، والكفــاءة الذاتيـة،

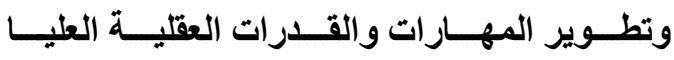
(Castle, 2014; Anderson, 2017; Nolan-Grant, 2019; Yandra et al., $.2021)$ - مكونات مجتمعات الاستقصاء عبر الويب. 
الجمعية المصرية لتكنولوجيا التعليم

المعسارف والخبرات السـابقة لديسه، بموضـوع

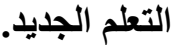

- اندماج وتكامل المجموعـات، مـن خلال إتاحـة الفــــرص للمجموعـــــات لتجميــــع الآراء و الاهتمامــات، وتنظـيم وتكامسل تلــــ الآراء لتكوين المعارف المتطلبة لموضوع التعلم. - - تقديم المساهمات على المستوى الفردي، حيث يتم توفير الأنشطة الاستقصائية التي تعزز من قـــرة المـتعلم عـى الاســفادة مــن الآراء و المعـارف التي تكونـت لايـه في تقديم حلول تطبيقية للمهام التي كُلف بها. - تقديم المسـاهمات على مستوى المجموعـات، حيـث يـتم تـوفير مسـاحات النقــاش والحـوار وتبـادل الآراء ووجهات النظر التي تعزز من قــرة المجموعـة على الاسـتفادة مسن الآراء والمعارف التي تكونت لاى أعضائها في تقديم حلول تطبيقية للمهام الجماعية. ويضــف فيـوك (2020) أنسه يمكن تعزيـز الحضـور المعرفـي فـي مجتمعسات الـتعلم الاستقصائي من خلال: حريـة اختيـار المتعلم للمهام التعليميـة وتخطيط أهـدافها وتحديــ اسـتراتيجيات تعلمهـا، إدارة المناقثــات وممارسـة لعب الأدوار، تصسميم قواعد وتعليمـات واضـحة لعرض وجهـات النظر ونقد الآراء، تأكيد دور المتعلمين في تثـارك الموارد ذات العلاقة بالتعلم.
قدرته على ممارسة مهارات التفكير، والتعرف على كيفية البحث عن المعلومـات واستكثـافها مسن مصسـادرها المتنوعـة، وتـوفر الحسـافز و الدافعيـة لايسه، وقدرتـه على ربـط المعـارف النظريـة بالجوانـب التطبيقيـة، ومـن النـــاذج التـي تُظهر مسـتوى الحضـور المعرفي لـلى المـتعلم ( تقـــيم أوراق عمـل، إعداد التقــــير والملخصات، إعداد العروض التقديمية، جمع وتصـنيف المـواد، عمـل المشـروعات، تنفيـذ

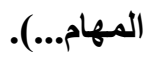
وأثـار تثين Chen et al., (2017) إلى أن الحضور المعرفي يمكن تنفيذه في ضوء الإجراءات

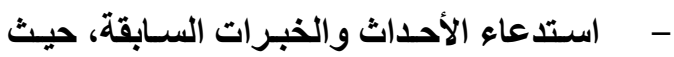

يـتم التعـرف على خبـرات المـتطلم ومهاراتـهـ السابقة ذات العلاقة بموضوع التعلم الجديد. - استكثــاف المستعلم مسن حيـث إتاحسة فـرص التفاعل له لتحديد ميولـه واهتماماتـه وخبراتـه والتصورات أو المعتقدات لايه. - استكثــاف المجموعـات مـن خــلال حـث المجموعات على تبادل الآراء ووجهات النظر وعمـق التسـاؤلات والـردود للتمكن مسن فهـم

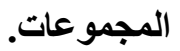

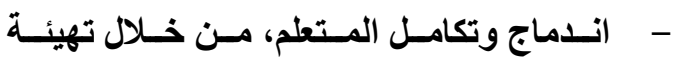
الفـرص المناسـبة للمـتطلم للـتمكن مسن ربـط

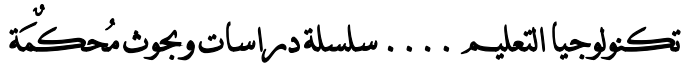


العامل الأقوى في التتبؤ بالرضـا عن التعلم مقارنـة بالحضور المعرفي والحضور التعليمي، وينـاءً عليه يمكن تطوير الحضـور الاجتمـاعي مـن خـلال تهيــة مجتمعسات التتعلم الاستقصسائي بالثـكل الــي يتيح الفرصة للمتعلمين للتفاعل بشكل جيد مـع المعلمين و أقر انهم ومعلميهـم، والتواصـل الهـادف فـي بيئسة تتسم بالأمان والآلفة، وتثبع المتعلمين على تعزيز

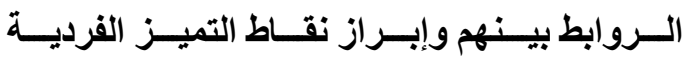
والجماعيـة، واســـتذام الأنثـــة الاستقصــائية المعززة للعصف الذهني والتشارك.

Teaching T- الحضور التعليمي (التدريسي) Presence (التريسي) بتصميم وتنظيم المهام والأنشطة التعليمية في مجتمعات التعلم الاستقصائي عبر الإنترنـتـ، حيـث يشـير إلسى مسـتوى ملائمسـة

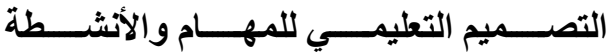
الاستقصـائية وتنظيمهـا، و إدارتهــا، وإتاحسة الوصـول إليهـا، وتـوفر الــــم المناسـبـ كـمً وكيفًا، وصولَا لتحقيق نتائج تعليمية ذات قيمة بالنســبة للمـتعلم علــى المسـتوى الفـــدي، ويالنســبة للمتعلمـين علـى مسـتوى مجتمـع التعلم، ويُسـتلال علـى الحضـور التعليــي مسن خلال تحقق سـهولة الوصول والقابليـة للتعلم والقابليـة للاسـتخدام، التــي تتـوفر لمجتمعـات الـتعلم الاستقصــئي عبـر الإنترنــت، وتتـــوع أشـكال تعزيـز الحضـور التعليمي، مـن بينهـا:
بـ الحضـور الاجتمــاعي Social Presence، ترتكز مجتمعات الاستقصساء عبر الويب على فكرة الحضور الاجتماعي، حيث تُعد التفاعلات

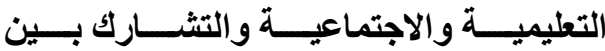
المتعلمين وبعضـهم ومـع المعلم ومـع مجتمـع التطلم مطلبًا مههًا يأتي في أولويـات مطوري بيئات التعلم عبر الإنترنت، ويشير الحضور الاجتمــاعي إلـى مجموعـة المهـارات التــي يمارسها المتعلم في التعبير عن ذاته، وتعزيز الترابط الاجتماعي بينها وبين أقرانهه و المعلم، واسـتخدام التلميحـات الاجتماعيـة، وإجـراء الحوارات الهادفة، والتعبير عن رأيسه، وإبراز نقــاط تميـزه، واســتخدام أســاليب التواصـل المتزامنــة وغيـر المتزامنــة، وذكــر تثــين Chen et al., (2017) الاجتمــاعي يتكون مـن ثـلاث مكونــات فرعيـة هـى: الســـات والمثـاعر العاطفيـة وتثــمل (التعبيـر عـن المشـاعر ، اسـتخدام التلميحـات الاجتماعيـة، رسـائل وعبـارات الترحيـب..)، حرية التفاعل والتواصل مـع الآخرين (التعبير عـن الــات، تبـادل الحسوار والنقــاش، تبـادل الخبـرات والتجــارب الثخصـية، التعــارف)، نسق وتتظيم المجموعات ( التعاون، الثـعور بالانتماء، توفر الدعم والمساندة).

Yandra et al., وتوصلت دراسـة ياتدرا (2021) إلى أن المتعلمين أظهروا ميلاً أكثر نحو الحضور الاجتمـاعي، وأن الحضور الاجتمـاعي كـان 
الجمعية المصرية لتكنـولوجيا التعليم

وإدرالك العمليات والإجراءات التي تكمن في تصميم وتتفيذ الأنشطة.

وفي ضـوء مـا سبق يمكن تحديـ الاعتبـار ات التي يجب مراعاتها عند تصميم وتطوير مجتمعات التعلم الاستقصائي عبر الويب:

أ- التهيئة الاجتماعيـة عبر الإنترنـت وتتضـمن: إدارة توقعــات المــتعلم، تخصــيص مســاحة للتشارك والتعبير عن الذات وإظهار الامكانـات الفرديـة وعرض التجـارب الشخصية، نمذجـة السـلوكيات المناسـبة، تحديـ قواعد التثـارك وتبـــادل الأدوار وطلــب الـــــمم أو تقديمـــهـ للأقران، استثارة الدافعيـة وربط التعلم الجديد بالخبر ات السـابقة، تفهم تفضيلات المـتعم أو المتعلمين، تعزيز الترابط بيز أعضـاء مجتمـع

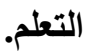
ب- تصـميم الـدعم والتـداخلات التعليميـة ويشـل:

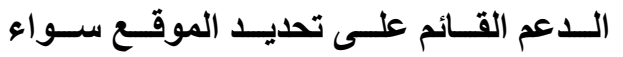
باستخدام GPS أو رمـوز الاستجابة السريعة والأي يتضـمن تقديم ارشـادات تشساعد المتعلم على الوصسول لهدفه، الدعم الإجرائسي والذي يهـدف إلى تقديم ارشسادات إجرائية لمسـاعدة

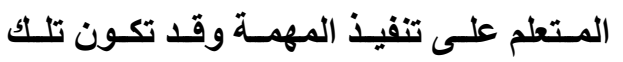
الإرشادات موجهة بالأسئلة أو السيناريوهات، أو القوائم والروابط، والدعم ما وراء المعرفي والأي يتضمن ارشاد المتعلم للنقاط التي يجب التفكير فيها وتتظيمها.
إجـراءات التخطيط والتنفيـذ والتقيـيم للمهــام التعليميـة ( تقــيم عـروض، تصــميم مقــاطع فيديو، أوراق عمل، محاضرات، عرض آراء، تقـــيم إرشــادات بشـأن كيفــة تنفــذ الـتـعم، تصميم أنشطة مـا قبل التعلم، تقديم التعليمـات المباثـرة، تأكيــ الفهــ، تثـخيص المفــاهيم (الخاطئة). وأكـدت عديـــ مـن الدراسـات أهميـة الحضـور (Yandra et al., 2021; Fiock, التعليميس 2020; Heilporn \& Lakhal, 2020) lee et al., أشسارت دراسـة لي وآخرون (2020) إلـى إنـا بـالرغم مـن وجـود تـأثير مباشـر للحضـور المعرفـي والحضــور الاجتمــاعي، وأن الحضــور التعليمسي لـه تـأثير غيـر مباشـر؛ إلا أن الحضــور التعليمي مكون مهم لا يجب إغفالـه، وهذا مـا أكدته دراسـة (Tao \& Zhang, 2018) حيث أشسارت لضــرورة الاهتمـــام بتصــميم وتنظــيم الأنثـــة الاستقصـــائية، وعمليــات التفاعـلـل والتثــــارك، وضــرورة الاهتمــام ببنــاء ومعالجــة المعلومــات وتطبيقها في العـالم الحقيقي، بمـا يمكن الطلاب من تحديـــ حاجــاتهم للاستقصــاء ورصـــ إجــراعات الاستقصاء. بناءً عليه يمكن القول إن التصميم التعليمي هو الركيزة الأسساسية لتحقيق الحضور التعليمي، حيث تنظيم وتصميم المهام والأنشطة، وتقديم التعليمـات المباشـرة والــدعم، وإتاحسة فـرص تبــادل الأقكـار، تصكولوجيا التعليـم . . . . سلسلةدماساتوبجوثمُحصِمة 
الجمعية المصرية لتكنولوجيا التعليم

الأشسارة لمصسادر أو روابط أو مراجع، الدمجج

والتكامل من خلال تكامل الافكار المختلفة.

هـ تنفيذ أنشطة التعلم القائم على الاستقصاء عبر

$$
\text { الويب، وتثثمل الإجراءات الآتية: }
$$

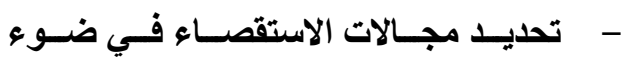

استفسار ات الطلاب وتفضيلاتهم وخبراتهم

السـابقة، حيث يقوم المعلم بتحديـ مجـال

الاستقصـاء وتهيئسة الأنثـطة و المصـادر

وإدارة المناقثـــــات، ويقــــوم المــــتعلم

بالمشـاركة في تنفيـذ الأنشـة ومشــاركة

الأسئلة والملاحظات مـع المعلم والأقران،

والانضمام لمجموعة تعلم ومناقثـة الآراء

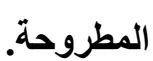

تنفيذ أنشطة التعلم الاستقصائي حيث يقوم المتعلم بالمشـاركة في المناقثـات الفرديـة والجماعيـة وصـولَا لإجابـات على أسـلتله،

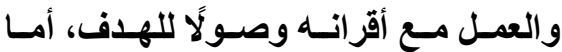

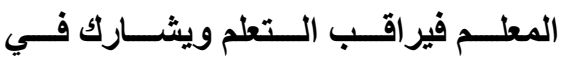
المناقثـات فـي ضـوع مسـتوى الاحتيـاج للتداخلات.

- على الاستمرارية في مجتمع الاستقصاء، حيـث يراقب المعــم معـدلات التقــــم فـي

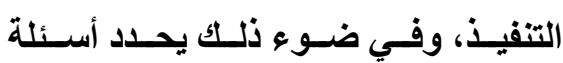
متعقة و أكثر تخصصية، ثم يقوم المتعلم
ج- تصميم محتوى التعلم الاستقصسائي ويتضمن: تنويـع طـرق الوصـول للمحتـوى ومصــادره سواء الوصول الثابت (من خلال مستودعات تعلم ثابتة ومحتوى معد مسبقًا)، أو الوصول الــيناميكي ويشـمل (التصـفح، الاسـتعراض، البحـث، تطــوير خـر ائط مفــــيم، منتــديات، مدونات، ويب تثــاركي) اعتمـاداً على نثـاط المتعلم. دـ تطوير الاسئلة الاستقصائية باستخدام الهياكل المعرفيـة والسيناريوهات، وقد تكون الهياكل المعرفيـة أو الســيناريوهات إمــا توجيهــات مشـتركة حسل مــا يجب أن يقوم بـه المـتطلم لتنفيذ المهمـة، أو توجيهـات اجتماعيـة بثـأن إدارة وتوزيع الأدوار والمسؤوليات، أو هيكلة للعمليات ونمذجة الاجراءات التي يجب القيام

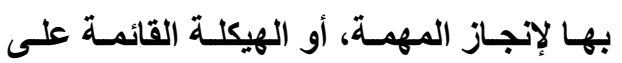
التبريـر والتي تتضـمن اقنـاع المـتعلم بأهميـة المهمة ولمـاذا يجب عليه القيام بها، وتنقسم

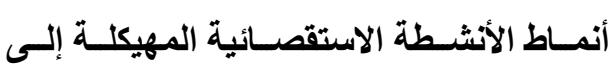
أسـئلة ( وهـى عبـارة عن أسـئلة واقعيـة، أو توضيحية، أو مثيرة للأفكار، تعميق وتفصيل)، وتنظير أو شرح تفصيلي ويشـمل (تفسيرات منطقيـة، تفسيرات بديلـة، شـرح مستقيض)، جمع المواد التعليمية والأدلة ويتضمن (وصف التجـارب والملاحظة وتقديم الأدلة و التبرير)، 
الجمعية المصرية لتكنولوجيا التعليم

انطلاقًَ مــــن الفلســفة البنائيـــة و البنائيـــة

الاجتماعية في التعلم، والتي ترى أن التعلم يحدث مـن خـلال المشــاركة الفاعلـة مـن المـتعلم في بنـاء

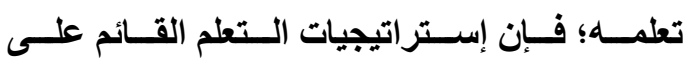
الاستقصاء تثير إلى مجموعة الإجراءات التي تعزز دور المـتطم النشـط مـن خـلال الاستقصـاء والبحث ســواء الموجـهـه أو المسـتقل، للتســاؤلات والمهــام التعليمية للوصول إلى إجابـات، وإستراتيجية التعلم القـائم على الاستقصــاء هـى إحـدى إسـتراتيجيات التعلم التي تهيء الفرص الملائمة للمتعلمين لإنجاز

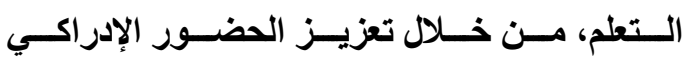
والاجتماعي والتدريسي، بما يؤدي إلى عمق التعلم والتفاعلات الايجابية المتبادلة، إضافة إلى الاستفادة من بيئة التعلم كمصدر للتعلم. وقــ اهتمـت عديـــــــن الاراســات بتوضـيح خطــوات تصــميم إســتراتيجية الـتطلم القـائم على لـى الاستقصـــاء، حيــث عـرض جـــودوين وكـــابلن Godwin and Kaplan. (2008) إستراتيجية التعلم القائم على الاستقصـاء في أربعة مراحل هى: المرحلة الأولى وتتعلق بالاستكشـاف أو التقصـــي وتثــــل اســتــعاء الخبــرات الســـابقة والتثارك في الأهداف التوقعات، أما المرحلة الثانية فهي مرحلة البحث وتثـمل البحث عن المعلومـات و الوصـول للمصــادر، وتنفيـذ المهــام والتكليفــات

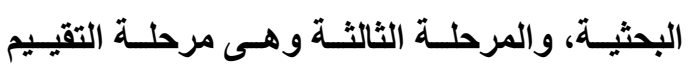
والمراجعة حيث تتضـمن تقيـيم مـدى الفائدة التـي هري
برســم خريطـــة للموضـــوعات الجديــــة المطلوبة لاستيفاء الاسئلة الجديدة، ويقوم بمشاركتها مع أقرانه. - - تنفيذ الأنشطة الفردية والتشاركية في جمع المعلومـات مـن خـلال عمليـات: التـدوين، كتابــة الملاحظــات، التمثـيلات المعرفيـة، خـــرائط المفـــاهيم والخــــائط الذهنيــة، الاختبارات والاسئلة الموجهة نحو مصسادر معلومات محددة. - - ـ إدارة تفــاعلات الأقــران ســواء المتزامنــة (محادثات فوريـة، استثــارات فوريـة)، أو غير متزامنـة (منتــيات، لوحسات وحلقـات نقاش، منصات عبر الإنترنت). - - توفير دعم السياق والذي يعتمد على إدراك سـياق أو بيئسة الـتعلم والمصسادر المتاحسة فيها لتمكين المتعلم من استكشافها.

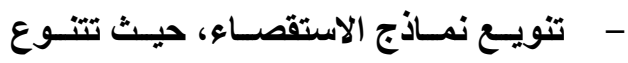
نمــاذج أنشـطة الـتعلم الاستقصـائي إلـى:

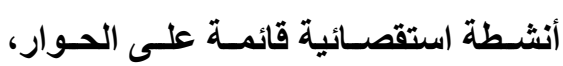
أنثـطة استقصسائية قائمــة على البحـث، أنثطة استقصـائية قائمـة على الممارسـة، أنثطة استقصسائية قائمسة على التطبيقـات الافتر اضية. - مراحـل تطــوير مجتمعــات (إســتراتيجية) الاستقصاء عبر الويب.

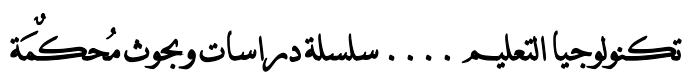


الجمعية المصرية لتكنولوجيا التعليم

والمرحلـة الخامســة وهـى المناقشـة و التأمسل فـي

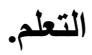

في ضوء ما سبق واستنادًا لما أشار إليه محمد

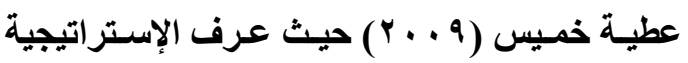

مجموعـة مــن الأنثــة والإجــر اءات التعليميــة

المحددة والمرتبة في تسلسل مناسب لتحقيق أهداف

تعليمية معينة، في فترة زمنية محددة، كما أشار إلى

أن الإستر اتيجية التعليميـة تتكون من ست خطوات هى: استثارة الدافعية والاستعداد للتعلم، تقديم التعلم

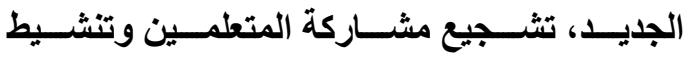

استجابتهم، قياس الأداء، تطبيق الاختبار النهائي،

وأيضًَــا فـــي ضــوء الخصـــائص التــي تكتســـها

الاستراتيجيات التعليمية في بيئات التعلم الإكترونية

عبر الويب، أمكن استخلاص مراحل استراتيجية

التعلم القائم على الاستقصـاء عبر الويب كمـا هو

موضح بالشكل (Y):
التعليميـة بأنهـا خطـة عامـة ومنظمـة، تتكـون مـن

تحققت من المصادر ومدى فائدة المعلومات التي تم تجميعهـا، وارتباطهـا بالمهــام التعليميـة المطلـوب إنجازهـا، ثُم المرحلـة الرابعـة وهـى مرحلـة بنـاء مجتمـع الـتـعلم القـائم علـى الاستقصــاء، وتثـــل الاستخلاص والتصنيف والمناقشـة وعرض النتائج

$$
\text { والتقييم الأتي والجماعي. }
$$

Pedast et al. (2015) ما بيدست وزمـلاؤه

فحد خطوات تصميم إستراتيجية التعلم القائم على الاستقصــاء فـي خمس مراحلـ هـى: التثـــارك أو

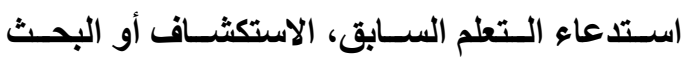
والتقصي، التوضيح وتبرير مـا تم التوصل إليها، التعقى والتفاصيل، التقييم والمراجعة، وحددها دي جونج وأخران (2014) De Jong et al. خمس مراحل بصيغ مختلفـة هى: المرحلـة الأولى التهيئــة والتوجيـه، المرحلـة الثانيـة التصــور أو التظظيـر والتــي تتضــمن طـرح الاســلـة وفـرض

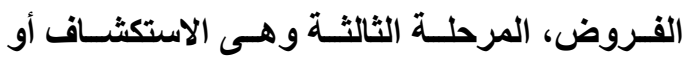
البحـث، أمـا المرحلـة الرابعـة فهـى الاسـتخلاص،

شكل (r)

مراحل إستر|تيجية التعلم القائم على الاستقصاء عبر الويب وإجراءاتها

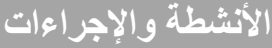

\section{المضور المعرفي} الامنور الإنماكي

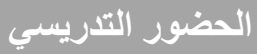

المرحلة

$$
\begin{aligned}
& \text { التعريف بمجتمع التعلم القائم حث المشاركين على اثث المشاركين على المشاركة في } \\
& \text { على الاستقصاء عبر الويب، التعريف بأنفسهم سواء عن المناقثات بشأن الأهداف }
\end{aligned}
$$

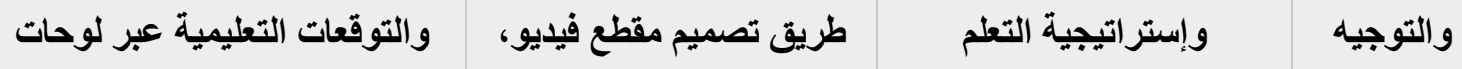

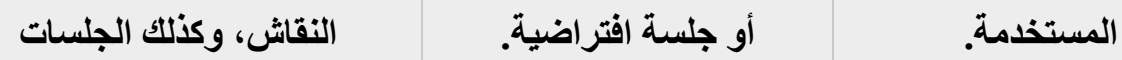


الجمعية المصرية لتكنولوييا التعليم

\begin{tabular}{|c|c|c|c|}
\hline الحضور المعرفي & الأششطة والإجز اعات & الحضور الثتريسي & المرحلة \\
\hline 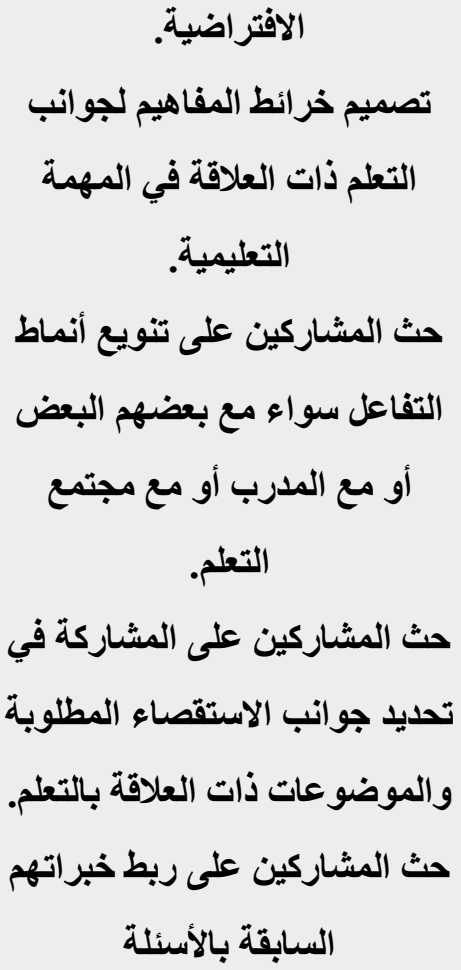 & 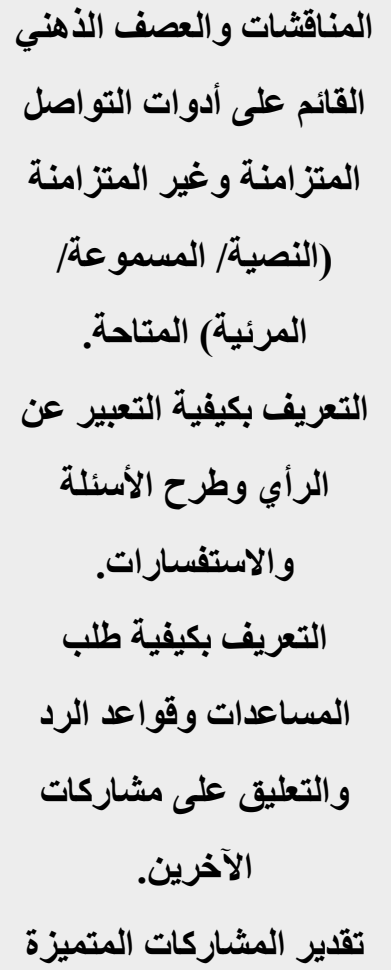 & 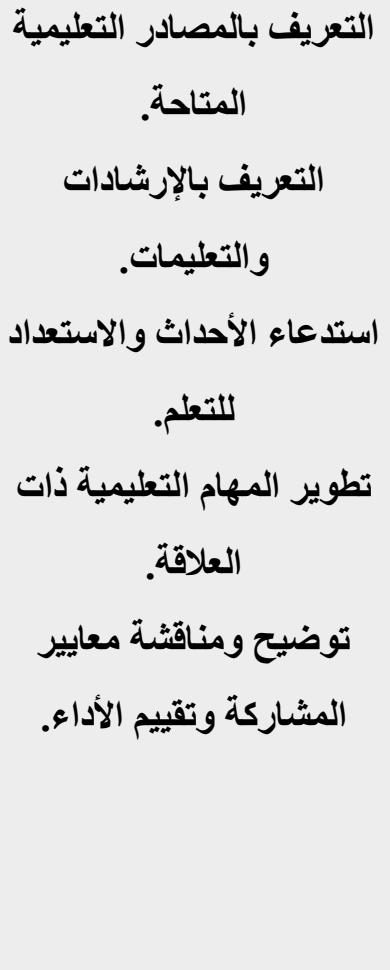 & \\
\hline 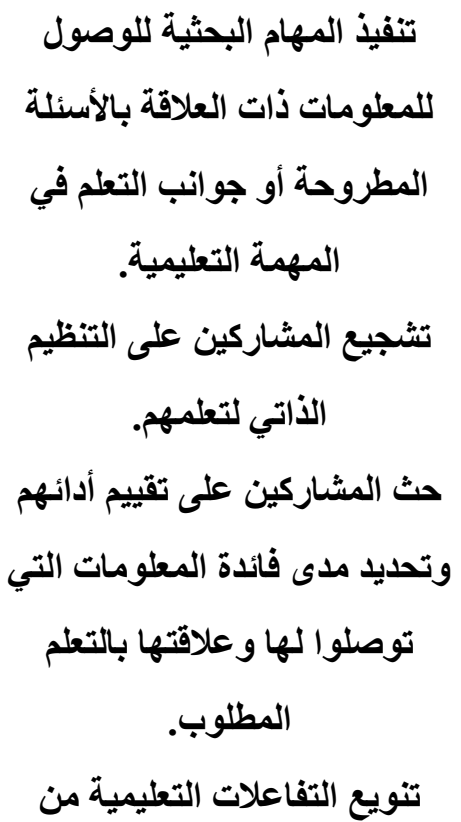 & 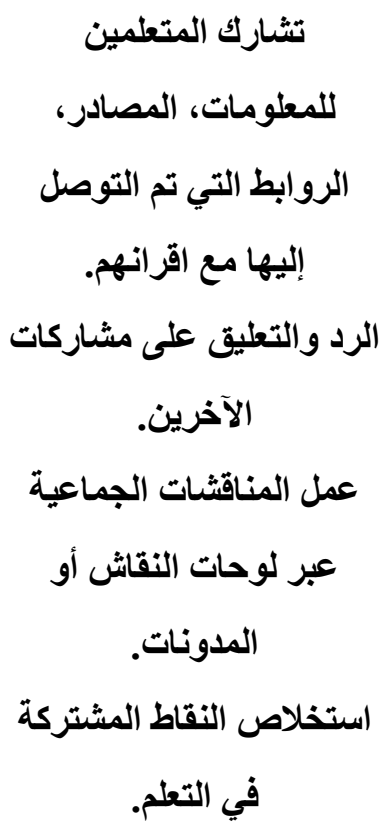 & 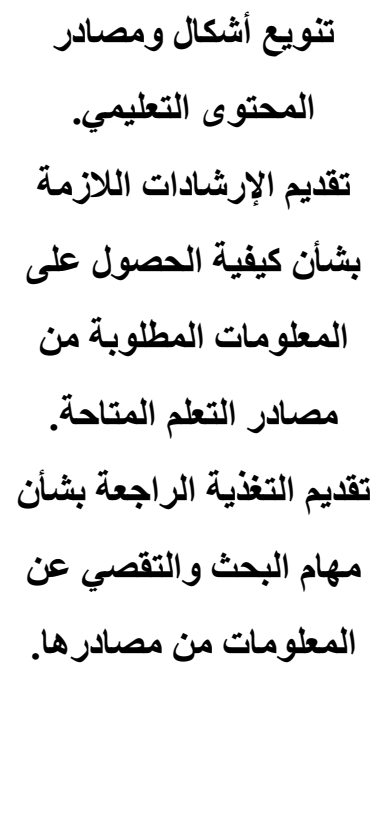 & أو الاستكثاف \\
\hline
\end{tabular}




\begin{tabular}{|c|c|c|c|}
\hline الحضور المعرفي & \multicolumn{2}{|l|}{ الأششطة والإجراءات } & المرحلة \\
\hline خلال الاجتماعات عن بعد & & & \\
\hline 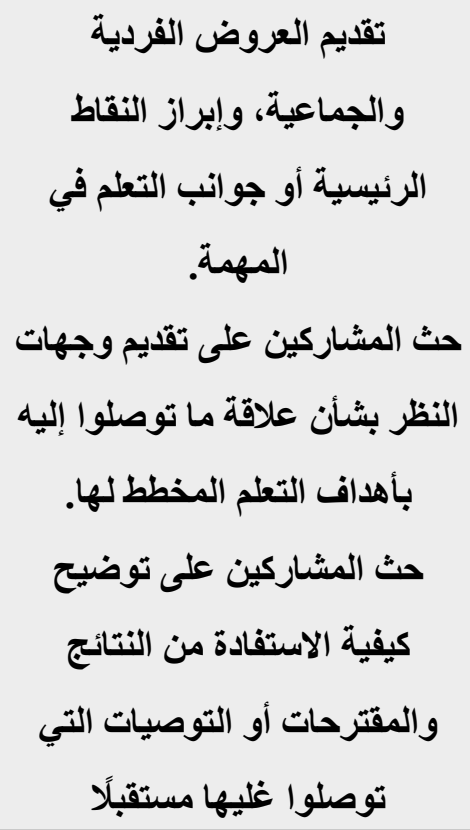 & تبادل الآراء ووجهات النظر تثلن ماتم التوصل إليه. & تقديم التغذية الراجعة بثأن & واستخلاص المنشة \\
\hline 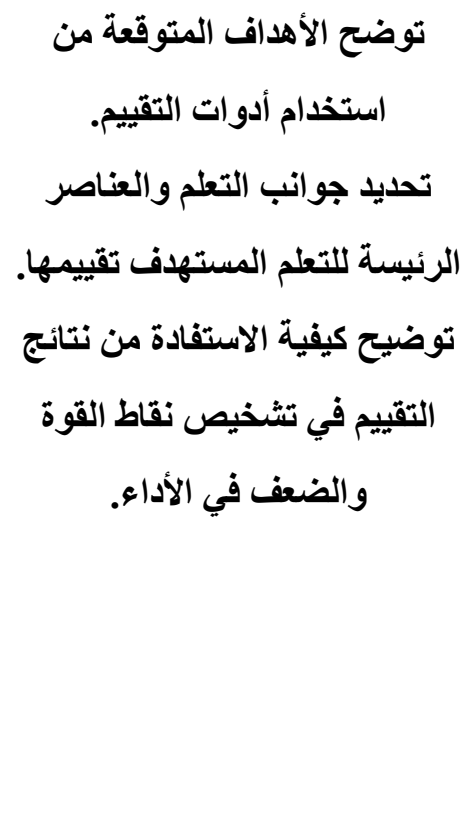 & 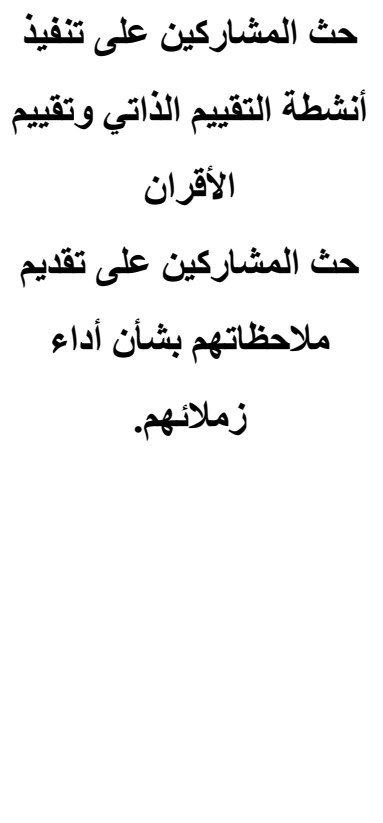 & 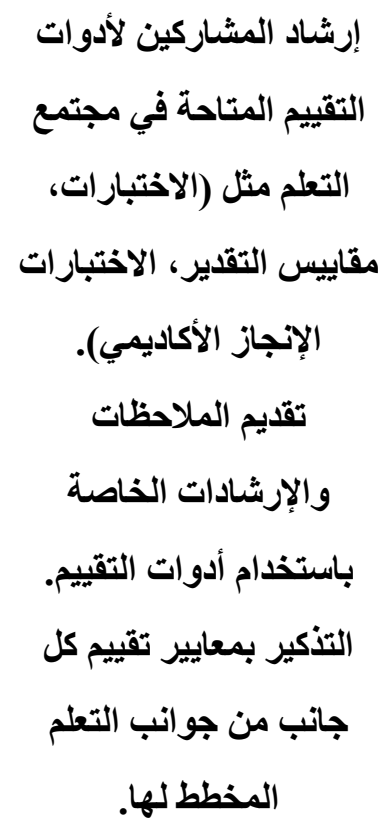 & والتياس \\
\hline
\end{tabular}


الجمعية المصرية لتكنولوجيا التعليم

تحديد أهدافه وطلب المساعدة وإدارة وتخطيط

- أدوات تطــوير مجتمعسـات الاستقصــاء عبـر

$$
\text { وقت التعلم. }
$$

$$
\text { الويب. }
$$

- ـ أدوات الادارة، وهــ تتضـــمن أدوات الاتاحسـة وطلب الدعم والبحث عن المعلومات.

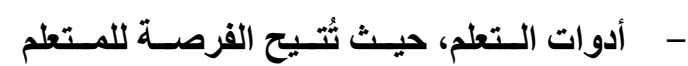
استكثـاف المصـادر والوصول إليها، وتطوير مجتمعــات الـتـعلم، مثــل محركسـات البحــث و المفضلات الاجتماعية وقواعد البيانات. - أدوات التقيـيم وتتضــمن الاختبـارات وتقيـيم الأقـران واسـتطلاعات الـرأي، والتــي تُمكـن المـتعلم مسن المراقبـة الذاتيـة لتعلمـه والتقيـيم

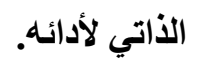

وفيما يلي - على سبيل المثال لا الحصر-أمثلة

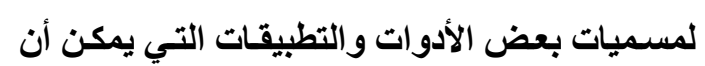
تُسهم في بنـاء وتطوير مجتمعات التعلم القائم على الاستقصاء عبر الويب:

والعصف الذهني وترتيب الأفكار وتنظيمها، و العمـل في مجموعـات وتـدوين الملاحظـات، وهي، كمـا يوجـد بـه قو الب جـاهزة لتوليد الأفكـار، ويلائم عديد من التطبيقات وعديد من الأجهزة

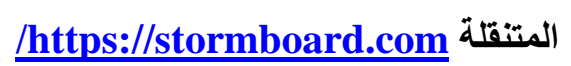
والمـتمطم إنثـــاء حـائط افتراضــي وتثـــارك الوسـائط المتعددة والملاحظـات عليها، حيث كي يتم تحقيق التكامـل بين منطلبـات التعلم المُنظم ذاتيًا، وخصائص مجتمعات التعلم القائم على لـى الاستقصاء عبر الويب، يجب أن يتوفر في مجتمع التعلم مجموعة من الأدوات والتطبيقات التي تمكن

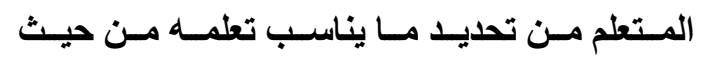
(المحتوى أو ماذا سيتعلم؟، الوقت أو متى سيتعلم؟، المكــان أو طبيعــة بيئــة الــتعلم؟، الإســتراتيجية المستخدمة أو كيف سيتعلم؟)، وكذلك توفر الرغبة والاستعداد للمشاركة في الأنثطة التفاعلية الداعمـة لبنـاء وتطـوير مجتمـع، ويحـد دبـاغ وكيتسـانتس Dabbagh and Kitsantas (2013) من فئات الأدوات التي يجب أن تتوفر في بيئة التعلم عبر الإنترنت لاعم التعلم المُنظم ذاتيًا وهى: - أدوات إنثاء وتقديم المحتوى: وهى مجموعة الأدوات التــي تســتخدم فـي تقـــيم المحتـوى والتفاعل مع مصادر التعلم، حيث تُكن المتعلم من تخطيط أهدافه وتوقعاته، وهيكلة المهرهـة وتنظيمها والتقييم الذاتي. - أدوات التواصل والتثارك، وهى مجموعة من الأدوات المتزامنــة وغيـر المتزامنــة مثــل:

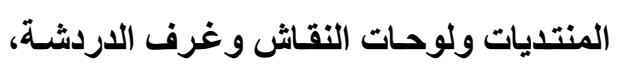
تبادل الملفات، البريد، حيث تُمكن المتعلم من وعن يمكن استخدامها في العصف الذهني وبنـاء 
الجمعية المصرية لتكنولوجيا التعليم

ت

والتكليف

/https://www.socrative.com - أداة bubbl انشـاء الخرائط الذهنيـة والتنظيم البصري للأفكار واكتثــاف الروابط والعلاقات

بينها /https://bubbl.us Google (Slide, Presentation, Docs,

Plus)

/https://workspace.google.com حيث يمكن تنفيذ الأنثـة الاستقصـائية في البحــث عـن المعلومــات و الوصــول إليهـــا

/https://webquest.org - مأداة Peer-assessment-tool أداة لتقيـــيم الأقران حيث يمكن للطلاب تقييم أداء بعض وتقــيم الملاحظــات وتلقةـي التظذيـة الراجعـة

https://www.golabz.eu/app/peerassessment-tool المحسور الثـاني: التنظيم الـذاتي للتنعلم في مجتمعات الاستقصاء عبر الويب. يتضـمن هذه المحسور: مفهوم التنظيم الـذاتي للـتعلم، الفاعليـة التعليميـة، إسـتراتيجيات التنظيم الــذاتي للــتعلم، نمــاذج التنظــيم الــذاتي للــتعلم، ومحفزات التظيم الذاتي للتعلم. - التظيم الذاتي للتعلم والمفاهيم المرتبطة به.
الاختبــارات، وجــعـع المصــادر والتواصـل،

وتبــادل الخبـرات وجمـع المصــادر وتنثـيط

-

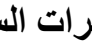
الخب

\section{/https://ar.padlet.com}

- مأداة blogger يستخدم لرسم الخرائط الذهنية والعصف الذهني عبر الإنترنت، حيث يمكن تنظيم الأفكار والحداق والربط بينها والتعاون كار والثث

/https://www.blogger.com/about أداة mindmeister تســتخدم كسأداة لرســم الخــــائط الذهنبــة عبــر الإنترنـــت وتـــوين

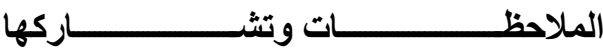

/https://www.mindmeister.com - أداة bookcreator انثاء الكتب الإلكترونيـة ومشــاركة الأفكـار والآراء، ودمـج الوســائط المتعددة وانثاء القصص التفاعلية والكتيبات /https://bookcreator.com - - أداة glogster انثــاء الملصـقات التفاعليـة طائl

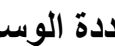
متع - n - n

/https://edu.glogster.com - أداة qr-code-generator مولــــ رمســوز الاســتجابة الســريعة للوصــول للمعلومــات https://www.qr-code/generator.com - أداة Socrative انثـاء الفصـول الافتراضية والتثارك والتقييم وتقييم التعلم وطرح الاسئلة

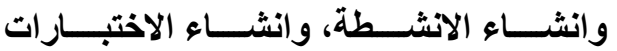


الجمعية المصرية لتكنولوجيا التعليم

وير اقبهـا، ويـنظم الــدوافع والســوكيات المرتبطـة

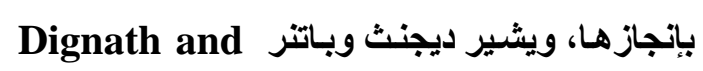
(Buttner (2018) (إلى أن التنظيم الذاتي للتعلم

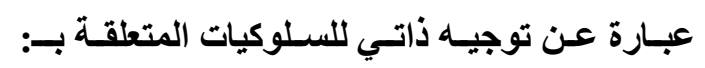
العمليـات المعرفيـة التـي يـنظم بهــا المـتعلم أفكـاره

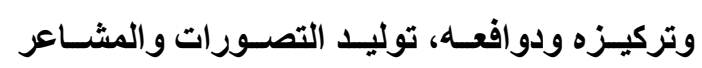

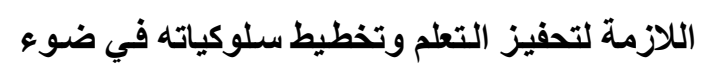
تلكك التصورات، تحويل القدرات العقلية إلى مهارات أكاديمية. - الفاعلية التعليمية لاستراتيجية التنظيم الذاتي للتعلم.

أهتمت عديد من الاراسات بالكثف عن العلاقة

بين التظيم الذاتي للتعلم وتحقُق الفعاليـة التعليميـة Arka et al. المخطط لها، حيث أكد أركا وزملاتهـيه (2020) أن مســتوى تـوفر التظظيم الــاتي لــى المـتطم يُعـد مـن العوامـل المنبئسة بمسـتوى كفــاوة المتعلم في التفاعل مع بيئة التعلم، وبالتالي مستوى

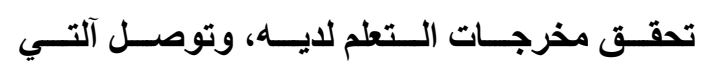
Altay and Saracaloglu وسـاركوغلو (2017) أن المتعلمين الذين يتوفر للديهم مستويات

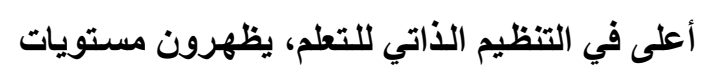
أعلى في أداء مهارات التفكير الناقد، والمهارات

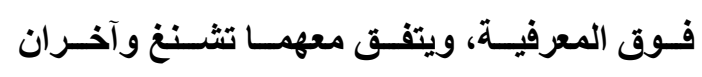
Zheng et al. (2020) يفتقرون لمهارات التنظيم الأتي للتعلم يكون أدائهم التعليمي أقل، وتوصلت نتائج الاراسـة التي أجراهـا
في ظل التحولات الرقمية و التوسع في استخدام بيئـات الـتطلم عبـر الإنترنــت، والتـي تتطلـب مسن المتعلمين قضـاء وقت طويل خلال التعلم، والتعامل مـع مصـادر تعليميـة متنوعة وكثيرة، دعت الحاجـة إلى البحث في آليات توظيف تلك المصادر والأدوات و التطبيقـات والاسـتفادة المثلى منهـا، ممـا تطلب حاجة المتعلمين لتطوير قدر اتهم على تنظيم تعلمهم و إدارتهـ والتحكم في وقت التعلم وتنظيمـه، وكذلتك إكسـابهم مهارات تحمـل مسؤولية التعلم و التحفيز الأتي، كما أن التعامل مع بيئات التعلم عبر الإنترنت يتطلب مهـارات عديـة منهـا: الاسـتقلالية، تحميل مســؤولية الــتعلم، التحفيـز والدافعيــة، الكفــــاوة و الفعاليـــة الذاتيــة، تنظــيم التفــــاعلات التعليميــة

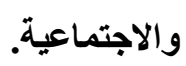
ويشير التنظيم الذاتي للتعلم إلى قدرة المتعلم

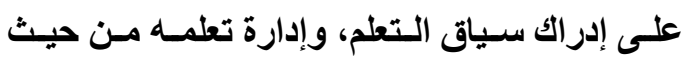

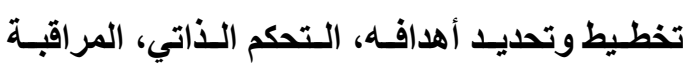
الذاتية للأداء، التحفيز الذاتي، التأمل وتقييم معدل التعلم في ضوء الأهداف المخطط لها، ويشير أركا وزملائهـ (2020) Araka et al. إلى أن التنظيم

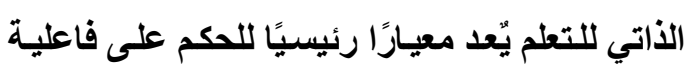
بيئات التعلم عبر الإنترنت؛ لما تتسم بـه بلتك البيئات مـن مرونــة واسـتقلالية في الـتعلم وغيـاب للـدور

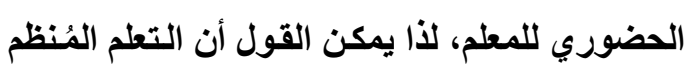

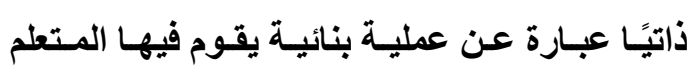

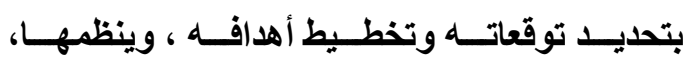

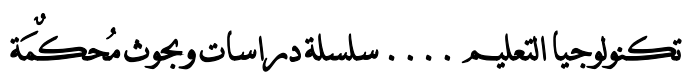


الجمعية المصرية لتكنولوجيا التعليم

و إدارة وقت التعلم وتنظيم جهوده والتحكم في تعلمهـ مسن خـلال التفكير في مـاذا يتعلم؟، وكيف يـتعل؟، وكيف يتحقى من إنجاز التطل؟.

واهتمـت عديـــ مـن الاراسـات بالكشـف عـن

العلاقة بين مستوى استخدام أو توفر إستراتيجيات التظظيم الـذاتي للتعلم والنتـائج التعليميـة المتُحقةـة (Basdogan, 2015; Cho \& Cho, 2017; Lodge et al., 2018; Zheng et al., 2020; Carter et al., 2020) الاراسات على وجود علاقة ارتباطية بين مستوى توفر أو استخدام إستراتيجيات التنظيم الذاتي للتعلم ومستوى الأداء والإنجاز التعليمي، وكذلك مستويات الحضور بأنواعه في بيئات التعلم عبر الإنترنت. - - أنواع إستراتيجيات التنظيم الذاتي للتعلم. في سياق الدراسـات التجريبيـة، أُجريـت عديـ مسن الاراسـات بهـف تحديـا إستراتيجيات التنظيم الأتي للتعلم في بيئات التعلم المختلفة، حيث حددتها (Ramdass \& Zimmerman, دراسـتي 2011; Lodge et al., 2018) اسـتراتيجيات هـى: اسـتراتيجيات معرفيـة تتضـمن العمليـات المطلوبـة لمســاعدة المتعلم على معالجـة

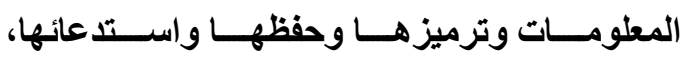
إستراتيجيات فوق معرفية وهى تثمل الأنثطة فوق المعرفيـة المرتبطــة بفهـم ومراقبــة والـتـكم فـي

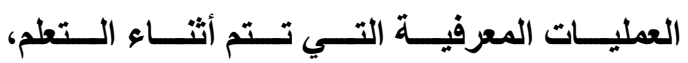

زيمرمان وتثنك Zimmerman and Schunk (2011) إلى وجـود علاقـة ارتباطيـة بـين مسـتوى تـوفر مهـارات التنظيم الـذاتي للتعلم والكفــاعة أو

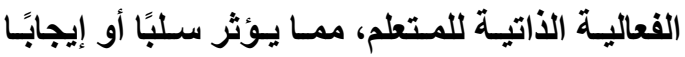
على الكفـاعة في التـلم وتحقيق الأهداف و إكمـال المهام، أمسا باسدوجان Basdogan (2015) فقد توصسلا لوجـود ارتبـاط إيجـابي بين مسـتوى تـوفر مهارات التنظيم الذاتي للتعلم والحضور بأنواعه في مجتمعات التعلم القائم على الاستقصـاء عبر الويب، وهذا ما أكدته دراسة وانج وزملائه . Wong et al. (2020) حيث توصلوا لوجود علاقة تبادلية بين التظيم الذاتي للتعلم و الكفاءة في التعامل مـع بيئات Kilis التطلم عبر الإنترنت، ويؤكد كيلز ويلدرم and Yildirim (2018) الأتي في مجتمعات الاستقصـاء عبر الويب لا يزال بحاجة لمزيد من البحث و الدراسة. ويعتمـد التنظيم الذاتي للتعلم على أطر نظريـة مسـتمدة مسن نمــاذج متنوعـة تصـف المراحسل والمكونـات و العمليـات والتـي تـتلخص فيمـا يُعرف بإسـتراتيجيات التنظيم الـذاتي للتعلم وهى تثــل: إدارة الوقتث، اسـتخدام المهــارات فـوق المعرفيـة، تخطيط الأهداف، تنظيم بيئة التعلم، طلب المسـاعدة والدعم، التأمل في التعلم والتقييم الذاتي، لذا يمكن القول أن إسـتراتيجيات التنظيم الـذاتي للتعلم هـى عبارة عن الأسـاليب/ العمليات المتنوعة التي يقوم بهـا المـتعلم بغرض تخطيط تعلمـة ومراقبـة أداءه 
الجمعية المصرية لتكنولوجيا التعليم

التطبيـق، والفئـة الثالثـة وهـى التأمسل وتتضــــن إسـتراتيجيتي التقيـيم الـذاتي والتعديل أو تصـحيح

Barnard et al. المسـار، أمـا برنـارد وزملائهـ (2009) فقـد حددوا اسـتراتيجيات التنظيم الـذاتي للتعلم في ست استراتيجيات هى: تخطيط الأهداف، طلب المساعدة والدعم، إدارة الوقت، تحليل المهام، تنظيم بيئة التعلم، والتقييم الذاتي، أمسا ين وزملائسه فen et al. (2016) والصبر، القدرة على التحكم، التأمل الذاتي، تحديد الأهداف، تنظيم بيـــة التتطم، تحليـل المهمــة، إدارة وقت التعلم، طلب المساعدة، التقييم الذاتي.

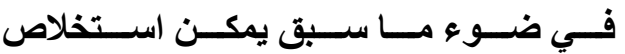
إسـتراتيجيات التظظيم الـذاتي للتعلم في مجتمعسات الاستقصـاء عبر الويب، والمؤشـرات الدالـة عليها كما هو موضح بالثكل (r):
إستراتيجيات تحفيزية وتشـل المواقف والاتجاهـات التي تؤثر على استخدام المتعلم وتطويره للمهارات Gu and المعرفية وفوق المعرفية، أمسا جو ولهي فحدداها في خمس إسـتراتيجيات Lee. (2019) هـى: إســتراتيجيات معرفيـة وتتضــمن العمليـات الداخلية المرتبطة بتمثيل ومعالجـة المعلومـات مثل (إعطاء التعليمات والإرشادات، الإيضاح والتفصيل، التنظـيم والهيكـــة)، إســتراتيجيات فـوق معرفيـة وتتضــــن التخطــيط ومراقبــة الــتعلم و إدارتـــه، إستراتيجيات تحفيزية وهى عبارة عن الجهد الذي يبذله المتعلم لفهم التطلم وتوليد الدوافع لهه وإدراك الإســتراتيجيات المســخدمة لتحقيـق أهدافـهـ مثـل المعرفــة الذاتيــة والكفــاءة الذاتيــة، إســتراتيجيات سلوكية وهى عبارة عن الإستراتيجيات القائمة على ملاحظة سلوك المتعلم والتحكم فيه، إضافة إلى قدرة المتعلم على تنظيم سلوكياته وتفاعلاته والتحكم فيها وطلب المسـاعدة اللازمـة، استراتيجيات سـياقية أو موقفيه، وهى تلك الاستراتيجيات المرتبطة ببادراك خصائص بيئة التعلم و إدارتها.

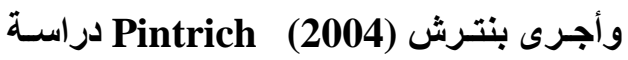
لاستقصـاء مستوى استخدام الطلاب لاستراتيجيات التظيم الذاتي للتعلم، حيث حدد هذه الاستراتيجيات في ثُلاث فئسات تثضسمن سبع اسـتراتيجيات وهس: الفئة الأولى التخطيط وتتضمن إستراتيجيتي تحليل المهام والاستدعاء والتعزيز، أما الفئة الثانيـة وهى الثى المر اقبة وتتضمن استراتيجيات التنظيم، التلخيص،

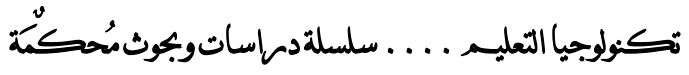




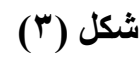

إستراتيجيات التظيم الذاتي للتعلم في مجتمعات التعلم القائم على الاستقصاء عبر الويب والمؤشرات الدالة عليها.

\begin{tabular}{|c|c|c|}
\hline المؤشرات الدالة عليها & & إستراتيجية التنظيم \\
\hline 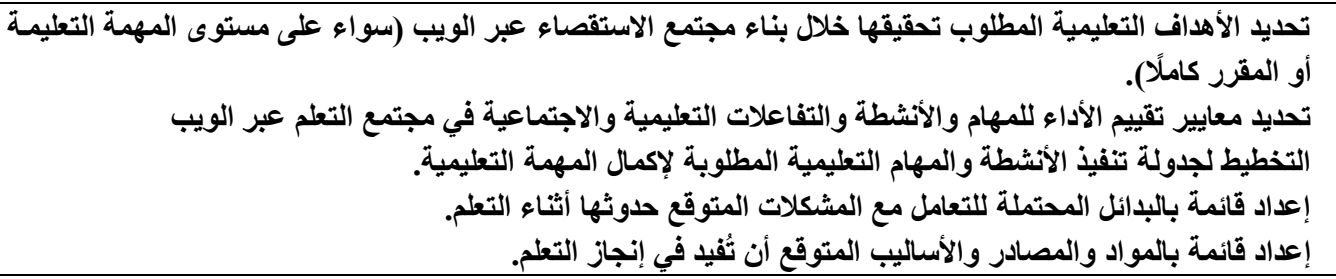 & $\begin{array}{l}- \\
- \\
-\end{array}$ & تخطيط الأهداف \\
\hline 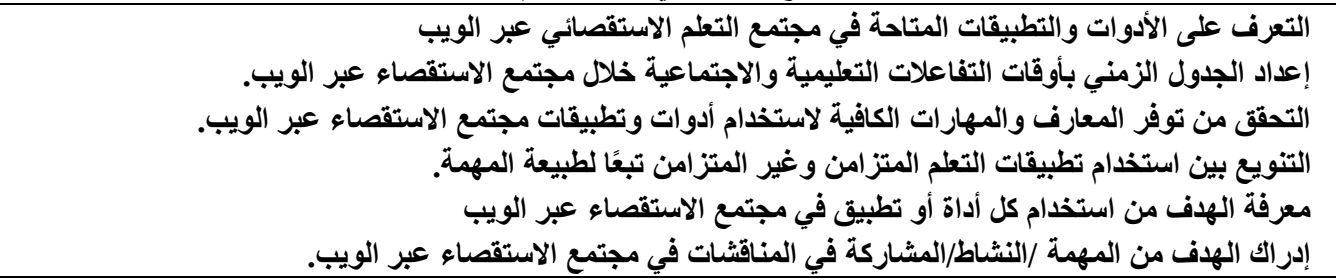 & $\begin{array}{l}- \\
- \\
- \\
- \\
-\end{array}$ & 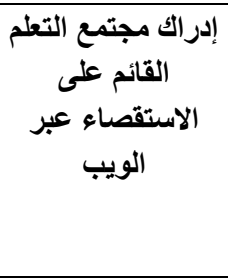 \\
\hline 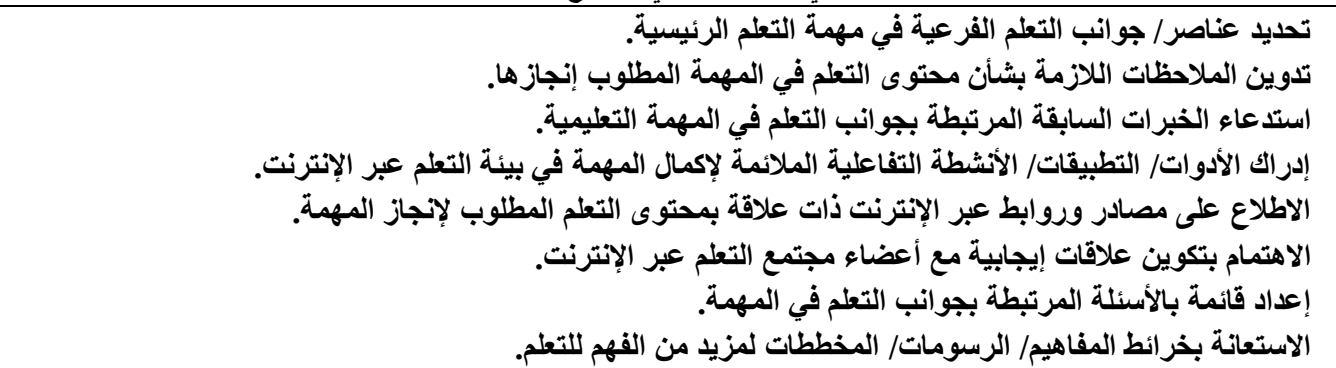 & $\begin{array}{l}- \\
- \\
- \\
- \\
- \\
- \\
-\end{array}$ & تحليل المهام \\
\hline 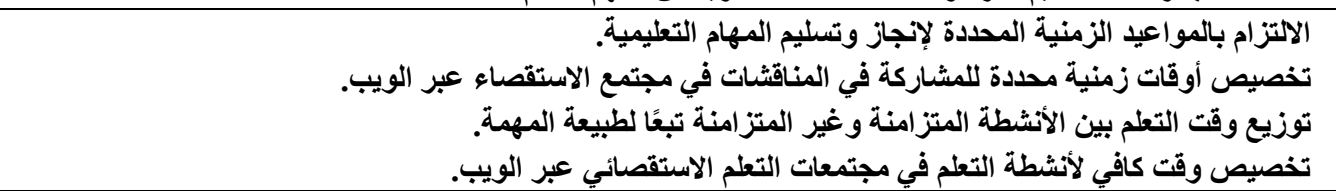 & $\begin{array}{l}- \\
- \\
-\end{array}$ & إدارة وقت التعلم \\
\hline 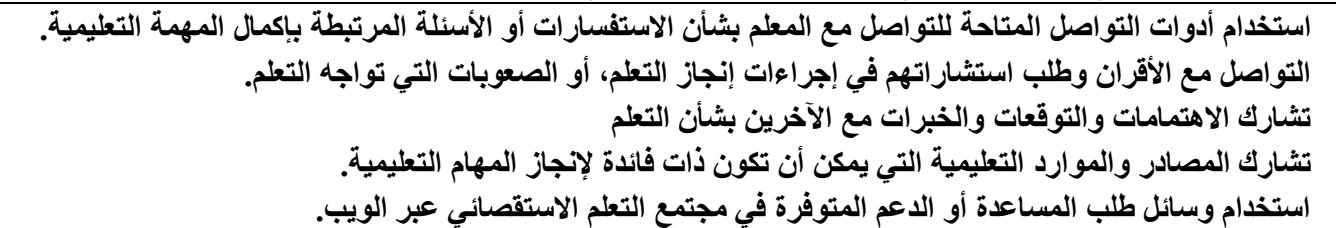 & $\begin{array}{l}- \\
- \\
- \\
-\end{array}$ & طلب المساعدة \\
\hline 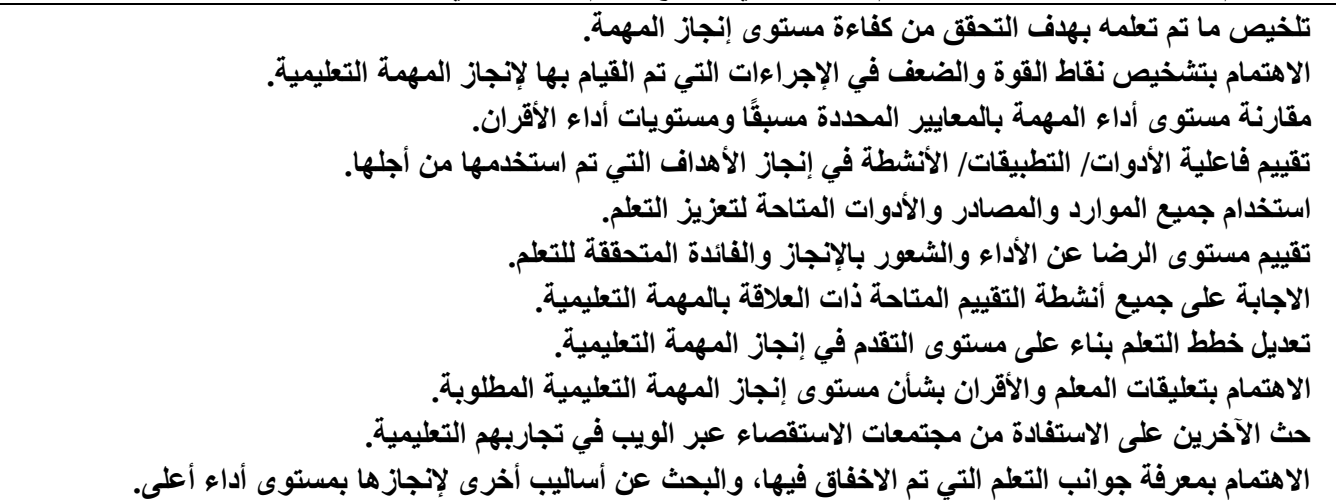 & $\begin{array}{l}- \\
- \\
- \\
- \\
- \\
- \\
- \\
- \\
- \\
-\end{array}$ & التأمل الأتي \\
\hline 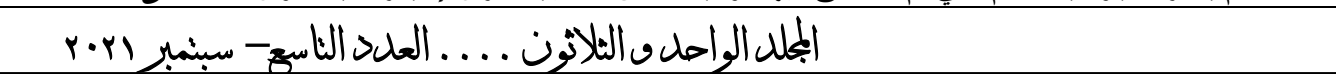 & & \\
\hline
\end{tabular}


الجمعية المصرية لتكنـولوجيا التعليم

الأهداف و التوقعات في ضوء معايير محددة للأداء،

خطوات بناء إستراتيجية التنظيم الذاتي للتعلم.

وتحديـــ الإســتراتيجيات التــي يعتقـــ أنهـا سـتكون

ملائمــة لإنجــاز المهــام التعليميـة، وتتضـــن هـــه المرحلة فئتين من الإجراعات هما:

- تحليـل المهـام التعليميـة: حيـث يقوم المـتعلم

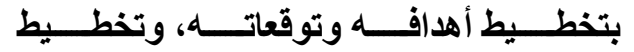
الإستراتيجيات التي سيستخدمها لإنجاز تعلمه. - - التصورات بثأن الدافعية الذاتية، وهى ترتبط بتصورات المـتطم بثــأن الفعاليـة الذاتيـة لـه، الفائـــة المتوقعـة للـتعلم، ومسـتوى الانتبــاه الــاخلي، ومســتوى توجهـهـ نحسـو الهــف

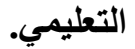
المرحلـة الثانيـة: مرحلة الأداء، حيث يقوم المتعلم بأداء المهمة لتحقيق أهدافه، مُستخدمًا مجموعة من الإجـراءات (تـــــين الملاحظــات، تركيـز الاتتبـاه، التعليمات، التلخيص) وتتضمن فئتين من الإجراءات

- الضبط/ التحكم الذاتي، حيث يستخدم المتعلم بعض التفاعلات الذاتية التي تمكنه من التحكم الـذاتي مثـل: التعليمـات والإرشـادات، تركيز الاتتبــاه، إعـادة الاطـلاع أو القـراءة، تـــوين الملاحظـات لمزيلـ من الفهم، القراعة بصوت عال، التقييم الذاتي. تجدر الأشــارة أن هنـالك نمــاذج عديـدة للـتطلم المُنظم ذاتيًا، منها على سبيل المثال: نموذج بتلر butler، نمـوذج بوكـارتس Boekaerts، نمـوذج وايـن وبيـري Winne and Perry، نمـوذج بنتـرش Pintrich، نمــوذج زيمرمــان ومــولان Zimmerman and Moylan تلكك النماذج في ركائز أساسية هى: المتعلم مُشـارك نشـط في بنــاء تعلمسه، وتخطيط أهدافـه، وتحديـا إسـتراتيجيات تعلمـه، يمكن للمـتعلم إدارة عملياتـهـ المعرفيـة، ودوافعـه، وسـلوكياته المرتبطـة بـالتعلم، المتعلم هو من يُحدد مدى توجـه تعلمـه نحو تحقيق أهدافه، المتعلم يمارس مهار ات للتنظيم الذاتي تعمل كوسيط بين أدائسه وخصائصسه الثخصية وظروف سياق التعلم Pintrich, 2000; Zimmerman) \& Moylan, 2009; Barnard et al., 2009; Ramdass and Zimmerman, .2011; Carter et al., 2020) وفي ضـوء النمـاذج التـي سـبق الأثــارة إليها يمكن القـول إن التنظيم الـذاتي للتعلم يمسر بـثلاث

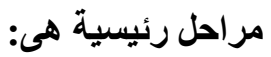
المرحلة الأولى: مرحلة التفكر أو التهيئة والإعداد، حيث يقوم المتعلم بتحليل المهام التعليمية، وتخطيط

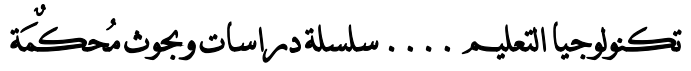


Alten et al., 2020) محفزات في صورة مقـاطع فيديو لتحفيز استخدام إستراتيجيات التنظيم الذاتي، أظهروا مستوى عالي

Schumacher من التعلم المُنظم ذاتيًَا، ويشبير and Ifenthaler (2021) الأتي تهدف إلى تنشيط إستراتيجيات التنظيم الذاتي

وفـي ضــوء مــا عرضــته بعـض الدراســات

(Zheng, 2016; Sletten, 2017; Araka et al., 2020; Zheng et al., 2020; Lee et al., 2020-a; de la Fuente et al., 2020-b) يمكن اسـتخلاص مجموعـة مـن محفزات استخدام استراتيجيات التنظيم الذاتي للتعلم في النقاط الآتية: أولاً: مرحلة ما قبل التعلم /التهيئة/ الإعداد وتتضمن عدد من الاعتبارات التحفيزية التي يمكن طلبها من التن

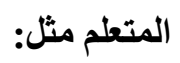
- - حث المتعلم على وصف استعداداه للتعلم، تدوين ملاحظـات، تحديـد الظروف التـي تسـاعده على تركيز الانتبـاه، تحديــ المعلومسات والمهـارات المتوفرة لايـه وتـرتبط بـالتعلم الجديـ، الإجابـة عن الاختبارات القصيرة للتحقق من استعداداه

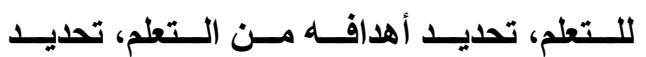
الإستراتيجيات التي يراها مناسبة لتعلمـه، مـاذا يتوقع أن يتعلم؟ - إعلام المشـاركين بالإستراتيجيات التي يمكنهم استخدامها في تنظيم تعلمهم تبعًا لكل مرحلة من مراحل الأداء.
- المراقبة الذاتية، حيث يراقب المتعلم عملياتهـ المعرفية ومـا وراء المعرفية والترميز الذاتي للمعلومات. المرحلة الثالثة: مرحلة التأمل الذاتي، حيث يتدبر المـتعلم فـي تعلمـه، فيحـد مسـتوى أداعه، ويقيميم فعاليــة إنجـــازه وفعاليـــة الاســـتراتيجيات التــــي اسـتخدمها، وتتضــمن هـــه المرحلـة فئتـين مسن الإجراءات هما: - التقيـيم الـذاتي، حيـث يقـوم المـتطلم بتقيـيم مستوى تقدمه نحو تحقيق أهدافه مبررًا نتائج تعلمه. - الاستجابة الذاتيـة، حيث يُحـد المتعلم رضـاه عن تعلمسه والاسـتراتيجيات التي اسـتخدمها، وطبيعـة اسـتجاباته الناتجـة عـن هـذا التقيـيم سواء تكيفية أو دفاعية أو تصحيح مسار. ويرتبط استخدام استراتيجيات التنظيم الذاتي للتعلم بمستوى التحفيز المتـاح في بيئة التعلم عبر الإنترنت، حيث أوردت عديد من الدراسـات للتأثير الإيجـابي لاستخدام محفزات التظظيم الذاتي، حيث

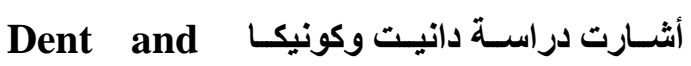
Koenka. (2016) التنظيم الـذاتي يسـهم فـي تحسين مهــاراتهم في

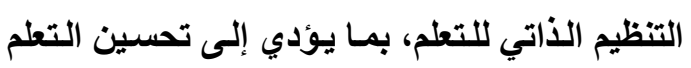

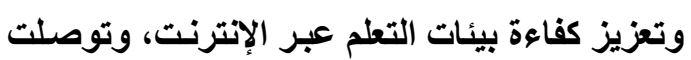
(Moos \& Bonds, 2016; Van نتائج دراستي 
الجمعية المصرية لتكنـولوجيا التهليم

- - حث المـتملم على تقديم إجابـات لبعض الأسـئلة مثل: مـا هى المعسارف والمهارات التي تعلمتها حتى الآن؟، وهل هناك موضوعات غير مفهومـة بالنسبة للك؟، ومـا هـى الصعوبات التي واجهتك أثناء التعلم؟

ثالثًا: بعد الـتعلم، وتتضـمن عـدد مسن الاعتبـارات التحفيزية التي يمكن طلبها من المتعلم مثل: - حث المشاركين على تدوين الملاحظات اللازمـة بشأن التعلم وتلخيص ما تم تعلمـه وتحديـ أوجهـ الاستفادة من التعلم. - استخدام مقاطع الفيديو والمحاضرات القصيرة، وطلـب تقــاريز، ملخصــات، عـروض تقديميـة، خرائط ومخططات للمفاهيم.

- ما هو تقييمك لمستوى أدائلك فيمـا يتعلق بإنجاز المهام التعليمية؟

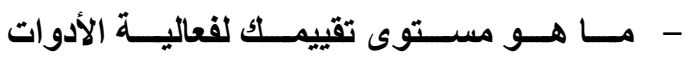
والتطبيقات والمصادر التي توفرت للك؟

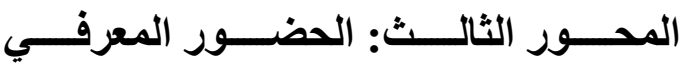
والاجتمـاعي في مجتمعات الاستقصـاء عبر الوبد.

يشـيز الحضـور المعرفي إلى مستوى إدراك المـتعلم لبيئـة الـتعلم ومشــاركته فـي بنــاء مجتمـع الـتعلم، وطـرح الأســئلة والاستفســارات، وتبريسر وجهـات النظر والتفاعل مـع المصــادر والتطبيقـات المتاحسة، والفاعليـة في تحديـد التوقعـات وتخطيط
- حث المشاركين على التعريف بأنفسهم من خـلال مقاطع فيديو قصيرة لتقوية الروابط الاجتماعية. - التحقق من توفر المعارف والمهـارات المتطلبـة لاــتعلم عــن طريـــق الاختبـــار ات القصـــيرة واستطلاعات الرأي، بما يعزز المعرفة والكفـاهة الأتية للمشاركين في التعلم. - حث المشـاركين في مجتمـع التعلم على تحديد توقعـاتهم وأهدافهم مسن التعلم ومشـاركتها مـع أقرانهم. - مشاركة المتعلمين في تحديد معاييز تقيّم الأداء للمهام والأنشطة التعليمية المطلوبة للتعلم. - تهيئة المشاركين من خلال التعريفـ بيئـة التعلم والمصسادر المتاحـة والإسـتراتيجيات المستخدمة والدعم المتوفر وآليات طلب الدعم. ثانيَّا: أثنـاء التتعلم، وتتضـمن عدد مـن الاعتبـارات التحفيزية التي يمكن طلبها من المتعلم مثل: - مث المشاركين على طلب المسـاعدة سواء من المعلـم أو الأقران، وتـوفير الأدوات والتطبيقـات ذات العلاقة. - - توفير وإعلان القواعد والتعليمـات والإرشـادات المرتبطة بمراحل إنجاز المهمة التعليمية. - استخدام الجلسات الافتراضية ولوحة المناقشـات وغرف الاردشة لمشاركة، وتبادل وجهات النظر والا هتمامات. - ت تتويـــع أدوات البحــث، الوصــول للمعلومــات، الـتحكم فـي المصــادر، طلـب الــــم والتغذيـة الراجعة. تصكنولوجيا التعليـم . . . . سلسلةدماساتوبجوثمُحصكمة 
الجمعية المصرية لتكنولوجيا التعليم

العاطفيـة والتلميحـات الاجتماعية ووسـائل التواصل

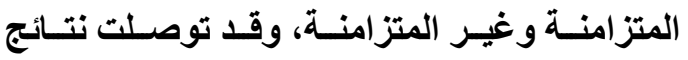
Akyol الدراسـة التي أجراهـا أكيوال وجارسيون and Garrison (2008) إيجابي بين الحضور الاجتمـاعي والرضسا عن التعلم في بيئات التعلم عبر الإنترنت، كمـا توصلت دراسـة Joksimovic et al. جوكسيموفك وزملائسهـ (2015) إلى أن الحضور الاجتماعي أحد المؤشرات

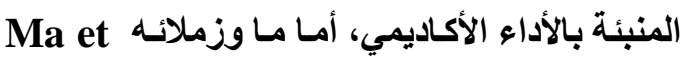
al. (2017) فأثشاروا إلى وجود علاقة إيجابية بين الحضور الاجتماعي والاتجاه نحو التعلم وبيئة التعلم عبر الإتترنـتـ، وتأكد ذلكـ أيضًا مـن خـلال دراسـة كوستلي (2019) Costley حيث كثفت نتائجها عن ارتباط إيجابي بين الحضور الاجتماعي والعبء المعرفـي الوثيـق أو المــرتبط، ويســهم الحضــور الاجتمـاعي أيضًا في تعزيز مهـارات التفكير الناقد (Costley \& Lange, 2016)، ويوكد هورزام (2017) (أن مستوى مشـاركة المتعلم في التفاعلات الاجتماعية يُعد مؤشرًا قويًَا للحضور Muljana and الاجتماعي، كما أثشار مالجانا ولو Luo (2019) بالانتمـــاء لمجتمـع الـتـطم يـرتبط بثــكل إيجـابي بالحضــور الاجتمـــاعي للمـتـعلم، ويؤكـــــــــــان Kozan and Richardson وريتشاردسون (2014) أن العلاقة تبادلية بين الحضور الاجتمـاعي والنـــوعين الآخــرين مــن الحضور(التـريســـي
الأهداف، واختيار الاستراتيجيات الملائمة لتحقيقها، ويـرتبط الحضــور المعرفـي بقـــرة المـتعلم علـى الاحتفــاظ بالمعـارف والمفـاهيم، مـن خـلال ممارســة مهــارات التفكيـر، والبحـث عـن المعلومسـات مـن مصادرها، والتحفيز الذاتي والدافعية للتعلم، وربط

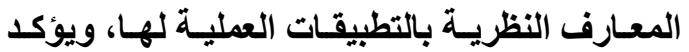
كوزان Kozan (2016) أن الحضور المعرفي يُعد مؤشر قوي للتنبؤ بالعبء المعرفي الدخيل والعبء Kozan المعرفي الكلي، أما كوزان وريتثاردسون aقـ توصـلا إلى and Richardson (2014) وجود علاقة ارتباطية تبادلية بين الحضور المعرفي والحضـور الاجتمــاعي والحضـور التـريسـي، وأن الحضور المعرفي يؤثر على العلاقة بين الحضور الاجتماعي والحضور التريسي، ويرتبط إيجابيًا مع الرضـا عن التتطلم والإنجـاز الأكساديمي، كمـا أثــار مالجانـا ولو (2019) Muljana and Luo إلى أن الانخراط في التعلم والثـعور بالانتمـاء لمجتمـع الـتعلم يـرتبط بثـكل إيجـابي بالحضــور المعرفـي

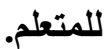
ويُعـــ الحضــور الاجتمــاعي بمثابـة المكـون المسؤول عن التفاعلات الاجتماعية، والتشسارك بين المتعلمـين ويعضـهم، وبيـنهم وبـين المعــم، حيـث يشير الحضور الاجتماعي إلى مجموعة السلوكيات التـي يمارسـهـا المـتعلم للتعبير عن ذاتـه، وتعزيـز التـرابط مــع أقرانـه، والتعبيـر عـن رأيـهـ وإبــراز شخصـيته ونقـــاط تميـزه، باســتخدام التعبيـرات 
الجمعية المصرية لتكنولوجيا التهليم

توقعـاتهم، تـداخلات المعلمم أثنـاء تبـاين الآراء ووجهــات النظـر، جدولــة إجــراءات الـتعلم وتفصيلاتها. - اســتخدام أدوات التواصـل المتزامنــة وغيــر المتزامنة مـع التركيز على التواصل البصري أو المرئي قدر الامكان. تحفيز الطلاب خلال الأنثطة الاستقصسائية من خـلال التركيز على: إعـلام الطـلاب بمـا سيتم ومـا هـو مطلـوب، اسـتخدام أدوات الاعـلان، تقــديم التعليقةــات للفـرد والمجموعـة، تقــيم

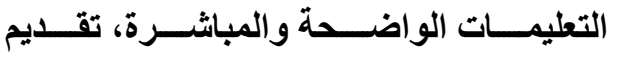
التــداخلات التفصـيلية عنــــ الحاجــة، تقـــيم التغذية الراجعة بالثكل والوقت المناسب. تشجيع مشاركات الطلاب، والتأكد من وضوح الأدوار والمهــام ومواعيـــ الاســتحقاق، مــع توفير الإرشادات اللازمة. البـــء مسن الخبـرات السـابقة وتـوفير فـرص الحـوار بشـأن الأهـافـ المطلوبـة مسن التتعلم، وتـدعيم النقـاش بشـأن المعنى وقيمـة التعلم وجودتـه، مـع تتويـع أسـاليب وادوات وتوقيت التثبيم. - - تثجيع الطلاب على تثـارك المـوارد التعليمية

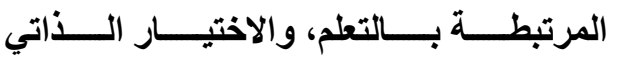
للموضوعات والمهام الاستقصائية. - - التدرج والتـوع في تصميم الأنشطة والمهـام

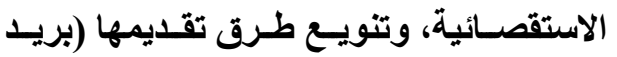

والمعرفي)، حيث يؤثر كل نوع في حدوث النوعين الآخرين وطبيعـة العلاقة بينهمـا، وهـا مـا أكدتـهـ Gutierrez- نتــائج دراســـة جــوتيرز وزملائسـهـ عندما توصلت إلى أن Santiuste et al. (2015) الحضور الاجتماعي عامل منبئ بالحضور المعرفي. وتُعد الأنشطة التعليمية القائمة على الاستقصاء هى ركيزة بنـاء مجتمعات التعلم الاستقصسائي عبر الإنترنت، لما لها من دور فاعل في تعزيز عمليات التثارك، والحوار، تبادل الآراء، التقد الأتي، تحمل مسؤولية التعلم، استخدام المهار ات فوق المعرفية، لكن يبقى التحدي قائمـاً ومتمثثلاً في كيفـة تصـميم وتنظيم أنشطة التعلم الاستقصسائي عبر الإنترنـت، ومن خلال الاطلاع على بعض الدراسات ذات العلاقة (Chen et al., 2017; Tao \& Zhang, 2018; Suarez et al., 2018; Fiock, 2020)

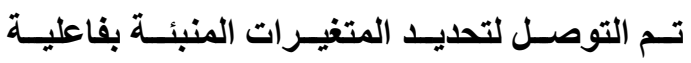
مجتمعات الاستقصاء عبر الإنترنت، من خلال تحديا الإسـتراتيجيات اللازمـة لتعزيـز الحضـور بأنواعـه الثلاث (المعرفي، الاجتماعي، التعليمي) على النحو

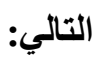
أ- اسـتراتيجيات تعزيـز الحضـور التلريسـي في مجتمعسات التعلم القـائم على الاستقصـاء في بيئة التعلم عبر الويب: - تطبيق مبادئ التصميم التعليمي وتتظم وهيكلة المهـام التعليميـة مـن حيث: تصـيم ارشـادات وتوجيهــات واضـــة، مشـــاركة المتعلمـين

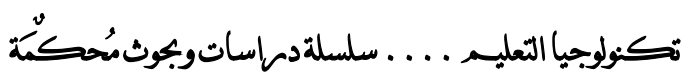


- التهيئـة الاجتمـاعيـة للمــتعلم/ للمتعلمـين مسن خــلال: مناقثــة أهـــاف الـتـعلم والتوقعــات، التعريــف ببيئــة الـتـعلم، عـرض التعليمــات والقواعد المباثـرة، اسـتخدام مقـاطع الفيديو سواء ذات العلاقة بمحتوى التعلم أو التجارب الشخصية للمتعلم. تتويـع وسـائل التواصـل، واسـتخدام الرمسوز التعبيزيــة، والتخاطــب بـالأســــاء، اســتخدام التلميحات الاجتماعيـة، تقدير وجهات النظر، نمذجة السلوكيات والتفاعلات الجيدة. أدوار، وتعزز الثـعور بـالأمن النفسي، والثقة بالنفس وتقدير الذات، وتثارك وعرض ملفات الإنجـاز، إزالـة الغمـوض وربـط التتعلم الجيــ بالخبرات السابقة، وتنويع أنشطة التعاون مثل المشروعات والعصف الأهي وحل المشكلات. تنويــــع الأدوات والتطبية المستخدمة في: التواصل، التثـارك، التحرير، السـرد القصصـي، عـرض التجــارب السـابقة باسـتخدام الـويكي وكتابـة المقـالات والتـدوين والمشاركة في المنتديات. هيكــة توزيـع الأدوار وتبادلهـا بهـدف تعزيـز التــــرابط الاجتمــــاعي، مشــــاركة التجـــارب والخبرات الشخصية ذات العلاقة. - تعزيز الثمولية والتشارك من خلال: استخدام لغـة حـوار قائمــة على المجموعـة، تلخـيص
الكتروني، ساحات نقاش ومنتديات، دردشـات، جلسـات افتر اضـية وعصسف ذهنـي، أنشـطة تعاونية، أسئلة استقصائية والرد عليها). - البعد عن التداخلات الزائدة، مع جدولـة المهـام والأنثــطة، واســتخدام اسـتراتيجيات تقيـيم الأقـران، والتحقـق مـن وضـوح الملاحظــات والتعليقات. - مراعاة تفضيلات واهتمامات المتعلمين كأفراد ومجموعـات، وتثـارك وجهـات نظـرهم فـي تعزيز التعلم. - استخدام التغذية الراجعة المرئيـة والمسموعة قدر الإمكان. - عـرف نفسـك للمتعلمسين وأطلب مـنهم نفس الثيء. - عزز استـمرارية الحـوار والنقـاش مـن خـلال طرح الاسئلة المفتوحة ب- إسـتراتيجيات تعزيز الحضـور الاجتمـاعي في مجتمعـات التتعلم القـائم على الاستقصـاء في بيئة التعلم عبر الويب: - تخصسيص مسـاحة للتشـارك الاجتمـاعي داخل مجتمـع التعلم (منتدى، مدونـة، ويكي، لوحة نقــاش، لوحة الإعلانـات، استطلاعات الرأي) يمكن من خلالهـا عمل الاتـي: التعـارف، تبـادل التجـارب والخبرات، عرض معلومـات وطلب معلومـات، التواصل الحر، عرض الاهتمامـات والتفضيلات، ملفات التعريف. 
الجمعية المصرية لتكنولوهيا التعليم

ج- إســتراتيجيات تعزيــز الحضــور المعرفـي

(الإدراكي) في مجتمعـات التتعلم القـائم على

الاستقصاء في بيئة التعلم عبر الويب:

تحديـــ أولويـات الـتعلم والنقــاش، ومحسـاور

الاستفسار، ونمذجة الأسئلة الاستقصائية.

تصميم وعرض المفاهيم والمعارف في صورة

مخططسـات وتمثتيلات بصـرية تبـرز العلاقـات

$$
\text { والروابط بين المعلومات وبعضها. }
$$

- تحديـد قواعـد وارشــادات ومســار ات النقـاش

والمشاركة فيه والأدوار المرتبطة به، وتوزيع

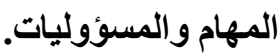

- ربـط الـتعلم الجديـــ بـالخبرات السـابقة لـدى

المــتعلم، مــع بيـان أوجـهـ العلاقـة مـن حيـث

التشابه و الاختلاف.

- ت تنويع مصادر المعلومات وآليات البحث عنها،

ووضـع نقـاط استرشـاديه، وتطـوير مراسـي

التعلم ذات العلاقة.

- توفير الأسسئلة الاستقصسائية التي تتطلب مسن

المتعلم إظهار قرته على التقد الأتي، والتأمل

فـــي الــتعلم، وتبريـــر الاجابــات، وتحليـلـ

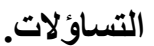

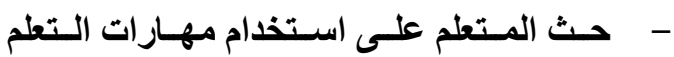

ومنها: التحليل، النقد، التلخيص، الاستتناج،

$$
\text { العصف الذهني. }
$$

- إتاحسة تطبيقـات تطوير مجتمعـات الاستقصـاء والتعلم عبر الإنترنت مثل: تشـارك المحتوى،
وبلـورة النقـاط الرئيسـية للحـوار، الاعتـراف بمســاهمات المتعلمـين، اســخدام التـــاخلات التعليمية التي تحـافظ على التركيز والدافعيـة باستمرار. - خصص لقـاءات وجلسـات حواريـة في بدايـة الـتـعلم لتعزيــز التــرابط والثــعور بالانتمــاء لمجتمـع التتعلم، مـع اسـتخدام مقـاطع الفيـديو

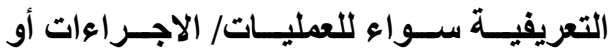
للمحتــوى، وأســاليب الوصــول، والاتـاحـة،

$$
\text { والتقبيم. }
$$
- دد قواعد واضحة لعمل المجموعـات وتوزيع المهـــام والمســؤوليات بـين أعضـــائها، مــع توضيح آليـة التعامـل مـع المسـاهمات الفرديـة والمسـاهمات الجماعيـة، الحرص على تدوين

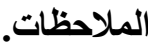
- ـث المشـاركين على التفـاعلات الاجتماعيـة والمشـاركة مسن خـلال: تخصسيص جـزء مـن التقدير للمشاركة، تعزيز المبادأة والردود على تعليقات الآخرين. - اسـتخدم محفـزات النقــاش مسن خـلال: دعـوة المــتعلم للقيــام بــدور قائــــ المناقثــة، طلـب التعليـق على مقـاطع فيـديو أو مصـادر تعلـم وتبرير التعليقات، استخدام آليات تتبع قراعاه الرســائل والـرد عليهــا، حـث الطـلاب علـى الاستثهاد بتعليقات وردود أقرانهم، أطلب من المتعلمين تلخيص موضو عاث النقاش. تصكنولوجيا التعليـ . . . . سلسلةدماساتوبجوثمُحهِّة 
الجمعية المصرية لتكنولوجيا التهليم

- - استكثــف المـتعلم كسأفراد ومجموعـات مسن

خلال: تثخيص الخبرات السابقة، تبادل الآراء

ووجهـات النظر، البحـث عن نقـاط الاهتمـام

المشتركة، ربط خلاصـات تعلم وآراء المتعلم

أو المجموعة بـالتعلم الجديد للشعور بالإنجـاز

والترابط والثعور بمجتمع التعلم.

- تعزيز الثقة بالنفس والدافعية للتعلم من خلال:

الاستثــهاد بـآراء ووجهـات نظـر المتعلمـين

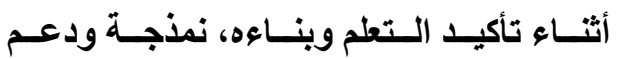

وتشجيع وجهات النظر ذات الفائدة لموضوع

التعلم

المحسور الرابـع: الضـغوط الأكاديميـة فـي مجتمعات التعلم عبر الويب.

أعلنــت منظمــة الصـحة العالميـة فـي مسارس

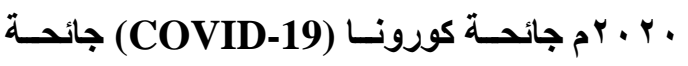
عالميـة في مختلف دول العـالم، وترتب على ذلتك تحديات عديدة من بينها: التحولات في أنظمة التعليم والتوجـه نـــو اعتمـاد أنظمـة التعلم عبر الإنترنتـ، حيث اتخذت المؤسسات التربوية إجراءات للحمايـة، مما فرض تحولَا نحو الحضور الافتر اضي في بعض لهض المقررات، وهذا التغير المفاجئ لم يكن الاستعداد لـه كاف، مما تسبب في فرض بعض الضـغوط الناتجـة عن أعباء إداريـة وتعليميـة وكنلك أعبـاء للأسرة، وأعبـاء على المتعلمين ذاتهـم، وسـواء كاتست تلكت الأعبـاء مرتبطــة بـالتغيرات النفسـية أو التغيـرات

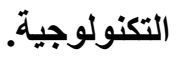

مشـــاركة الثـاثــة، اســتخدام أدوات الحسـوار و الدردشة، مراجعة وتقييم الأقران.

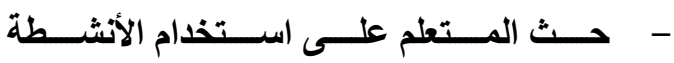
الاستقصـائية البنائيـة مثـل: المــدونات فـي الكتابــة والتــدوين، الــويكي فــي التثـــارك والتحرير، المنتديات ولوحات النقاش، خرائط المفاهيم والخرائط الذهنية. - إتاحـة التعليمـات والإرشــادات وسـقالات التعلم بثأن: عمليات التعلم وإستراتيجياته، محتوى التعلم والمخرجـات المتوقعـة، تقيـيم وتطبيق التعلم وحل المشكلات. - - تنويع فرص التعاون والتشـارك والبنـاء مثل: اســخدام مقـــع الفيـديو أو تســيل الثـاشــة وتقي ذيم ذاتـي، كتابـة مقـالات، إنشـاء صفحات ويب تثــاركي، إنشـاء مـدونات، مشـاركة في منتديات ولوحات نقاش، تقديم التظذية الراجعة للأقران أو طلبها منهم. - تعزيـز تحكم المـتطم وفاعليتهـه في التعلم مـن

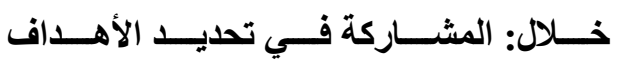
والتوقعـات، حريــة اختيـار أســاليب التعلـيم والتقييم، استخدام الاختبارات الذاتية، استخدام الأنشطة التفاعلية. - تنويـع التـاخلات التعليميـة مثل: طلب أوراق عمل، تقـارير، ملخصـات، عـروض تقديميـة، تسجيل مقاطع فيديو، بحث عن مصسادر، القيام بمشروعات، تنفيذ مهام... 
الجمعية المصرية لتكنولوجيا التعليم

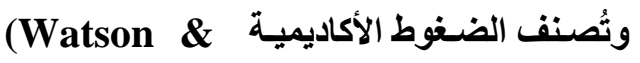

Watson, 2016; Jenaabadi et al., 2017;

Ruston \& Tentama, 2020) - ضغوط بيولوجية (جسدية): عبارة عن الجها العقلـي النـاتج عن اسـتجابة الجهاز العصبي و الغذد والذي ينتج عنه تفـاعلات فسيولوجية مثل التعب، الإرهاق، الصداع، سرعة ضربات

$$
\text { (القلب، التلعثم). }
$$

- ضسفوط فسيولوجية (نفسية): وهـ تتضــن الضغوط النفسية المعرفية (رد الفعال المعرفي للمتعلم عند الثعور بالضـط الأكاديمي والذي يتمثـل فـي نسـيان، ارتبـاك، تفكيـر سـلبي، الثـعور بعـدم الأهميـة، الصـعوبة فـي اتخــاذ القـرار، الثــور بعـــم الإتجــاز)، والضــوط النفسية العاطفيـة (حيث يقصــ بهـا مشــاعر

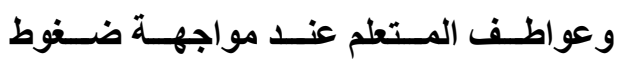
أكاديميـة مثل الخـوف، القلّ، الاكتئساب، عدم

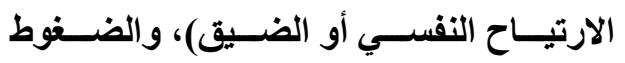
النفسية السلوكية (وهى عبارة عن سلوكيات المتعلم تجاه الآخرين نتيجة التعرض لضغوط أكاديميـة مثُل العزلـة، العداء، الاتطواء، عدم

$$
\text { (التعاطف مع الآخر). }
$$

واهتمت عديد من الدراسـات بالبحث في تأثثير الضغوط الأكاديمية على نتائج التُطم، حيث أشسارت

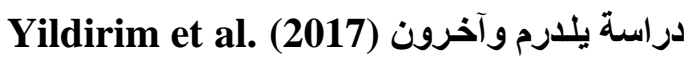
إلسى وجـود علاقـة سـبيبة بـين الضـفوط الأكاديميـة
ولـــم تكـن التحـــلات المترتبــة علـى جائحسـة

COVID-19 فتط هـى مصسدر الضـفوط؛ بـل إن التطورات في بيئـات التعلم عبر الإنترنت والتوسـع في استخدامها، ومـا يتعلق بخصائصـها مـن وفرة وتتوع في المصادر والموارد التعليميـة، وزيـادة في الطلـب عـى تحمـل المـتـطم لمســؤولية تعلمــهـ واستقلاليته، الأمـر الذي ترتب عليـه ارتبـاك لـدى المتعلمين، ممـا سـاهم في إحداث ضـوط أكاديميـة،

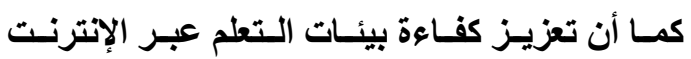
بالتطبيقات والأدوات الرقمية تسبب أيضًا في أعباء وضـوط نتجت عن ارتفـاع مستوى التوقعـات مـن هذه الأجيـال، وترتب على ذلك حدوث تـوتر للى (Faleel et al., 2012; Leppink et المتعلمين .al., 2016; Reddy et al., 2018) وتُعد الضـغوط الأكاديميـة بمثابـة ظـاهرة يعاني منهـا الطـلاب، خاصـة في ظل بيئـات التتعلم عبر الإنترنت وما يرتبط بخصائصها، سواء وفرة وتتوع المصادر والموارد، الاستقلالية وتحمل المسؤولية، كثرة المهام والتكليفات، التقييم عبر الإنترنت وتنوع

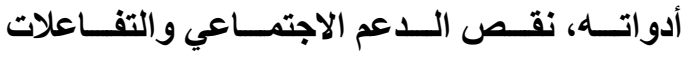
الاجتماعيـة الحضـورية، التقدير المـنخفض للذات، نقص الكفاءة الذاتية، الخوف من الفثل في تكوين علاقتات ناجحة مـن الآخرين، الحاجـة لقضـاء وقت تعلم أطول، التصـورات السـلبية نحسو بيئسة التعلم؛

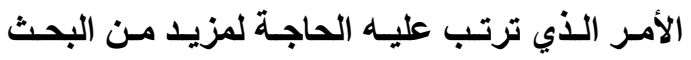

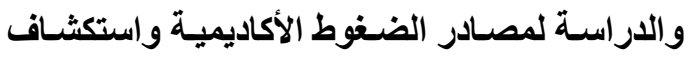
إستراتيجيات التعامل معها، بما يقلل من تأثير ها.

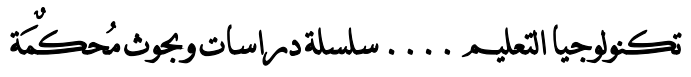


كثرة وتنـوع أشـكال المـوارد والمصسادر التعليميـة، الحاجـة لقضــاء وقـت طويـل في الدراسـة والتـعلم، ضعف البنية التحتية اللازمـة للتعلم عبر الإنترنت،

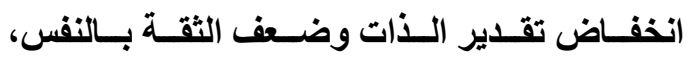
مشكلات إدارة وقت التتطلم عبر الإنترنـت، الخـوف مسن الفشـل، التوقعـات العاليـة لمسـتويات الأداو، صـوبات التعامـل مــع الآخـرين وتكـوين علاقــات ناجحة، عدم توفر الدعم والارشاد الكافي، التوجهات السبية نحـو بيئة التعلم عبر الإنترنـت، انخفـاض مستويات التنظيم الذاتي للتعلم، الخوف من التعلم بالأقران أو في مجموعات.

(Zenner et al., وتؤكد عديد من الاراسـات

2014; Bedewy \& Gabriel, 2015; Vohs \& Baumeister, 2016; Kaunhoven \& Dorgee, 2017; Mcclelland et al., 2018) وجود علاقة وثيقة بين مستوى مهارات التنظيم الـذاتي للـتعلم، والكفــاء فـي التعامـل مـع الضـغوط الأكاديمية (مجموعة المعارف والمهارات المعرفية وما وراء المعرفية، والتصورات، والمعتقات، التي يمكـن للمـتعلم اســتخدامها فـي مواجهـة الضــوط الأكاديمية وتقليل أثار ها)، حيث يُسهم التظظيم الذاتي للتعلم في زيادة الفعالية الذاتية، والكفاعة الذاتيـة في التعامـل مـع بيـــة التعلم، وإدارة وقت التعلم بشكل جيد، وتنظيم الجهود، وتخطيط الأهـاف وتحديـا معسيير التقيـيم فـي ضـوي الامكانـات والقـدرات، وبالتالي تخفيف أثار الضغوط الأكاديمية.
وتقدير الذات والحضور الاجتمـاعي، حيث يتأثران سـلبًا بزيـادة الضـفوط الأكاديميـة، وتوصلت نتـائج Karaman and راسـة كارمسـن وواتسـون Watson (2017) لوجـود علاقـة بـين الضـغوط الأكاديمية ومستوى الدافعية للإنجاز ، واتفقت معها Pascoe et al. تتائج دراسـة باسكو وآخران (2020) فتوصلوا لوجود علاقة قويـة بين مستوى الضـوط الأكاديميـة و التحصيل الدراسـي والدافعيـة Perfect et نحو التعلم، ويؤكد بريفكت وزملائسه al. (2016) القدرات العقلية وعمليات التركيز والانتباه، وأكدت Shorer and تنائج دراسـة شسور وليبوفتش Leibovich (2020) ارتبـاط عكسـي بـين مسـتوى الضـغوط الأكاديميـة والإنجاز الأكاديمي والتحصيل.

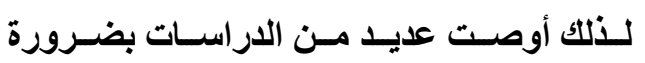
الكثـف عـن مصــادر الضـغوط الأكاديميـة، بهـدف التقليـلـل مــن أثثار هــا، حيــث حــدـت دراســات (Sreeramareddy et al., 2007; Radeef et al., 2014; Yikealo et al., 2018; Reddy et al., 2018; Ramli et al., 2018; Dolfen et al., 2019; Macintyre et al., 2020; Friskawati, 2021) الأكاديميـة في عدة مصسادر منها: مستوى التهيئة والاعـداد للاختبـارات الإكترونيـة، ضـعف الكفــاعة و الفعاليـة الذاتيـة، كثرة وتنـوع المهـام والتكليفـات، 
الجمعية المصرية لتكنولوجيا التعليم

المحور الخـامس: الدمـج بـين إسـتراتيجيتي

التنظـيم الــذاتي للـتـعلم ومجتمعــات الـتـعلم الاستقصائي عبر الويب.

تفترض نظريـة مجتمعسات الاستقصـاء عبر

online community of inquiry الإنترنت theory احتياجـات المعلمـين و المتعلمين للحضـور المعرفي

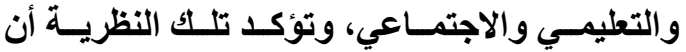
المتعلم بحاجة للحضور بأنواعه الثلاثة، وتقدم عددًا من الإرشـادات بشـأن إستراتيجيات تعزيز الحضور بأنواعه (Garrison \& Anderson, 2003)، وكذلك نظريـة الفضـاء المعرفي Transactional Distance Theory حيث تفترض تلكك النظريـة أنسه لحدوث التعلم يجب توفز ثلاثة مكونـات رئيسية لبنـاء مجتمعات التعلم هـ: التفـاعلات بـين المتعلمسين والمعلمسين، هيكل المحتــوى والأنثــــة التعليميــة القائمـــة علـــى الاستقصــاء، الـتـكم الــاتي واسـتقلالية المـتعلم

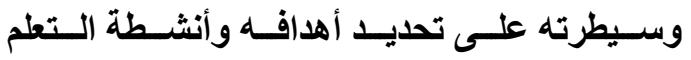
وإجراعات تنفيذه ومراقبته وتقييمه، وتؤكد النظريـة على ضرورة مراعـاة المسـاحة النفسية والتفاعليـة والتواصلية بـين المعلـم والمـتعلم خـلال مجتمعـات

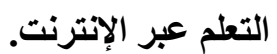
وتُعد مجتمعـات التعلم القـائم على الاستقصـاء عبر الويـب، مـن النمـاذج التـي يمكنهـا تلبيـة تلـك

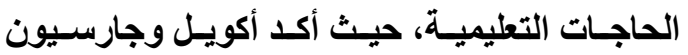

وللحـد مسن تـأثير تلكـ المصسادر أو التقليـل مـن أثار هـا السـلبية لابـــ مـن البحـث في اسـتراتيجيات

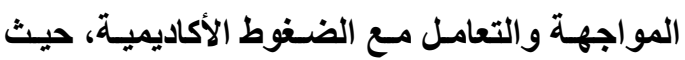
تُعرف اسـتراتيجيات مواجهـة الضـغوط الأكاديميـة بأنهـا الإجـراءات المعرفيـة والسـلوكية التـي يقـوم المـتعلم بهـا اسـتجابة للمواقف والمهـام التـي تقع خارج نطاق قدرات المتعلم، وهذه الإجراءات مرنـة ومتغيرة تبعًا لمسببات الضغط الأكاديمي، ومتطلبات التقليل من أثاره (de la Fuente et al., 2017)، وتنقسم إستراتيجيات مواجهـة الضـغوط الأكاديميـة إلى نـوعين مـن الإسـتراتيجيات همـا: إسـتراتيجيات تُركز على المهمة التعليمية ذاتها (تخطيط الأهداف،

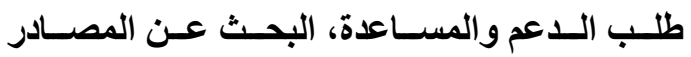
والمعلومات، التظظيم الجيد للمهمة التعليمية، إدارة وقت التعلم بكفاءة، الالتزام بجداول زمنية واضحة،

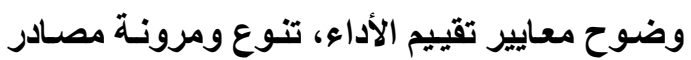
الـتعلم وسـهولة الوصـول إليهـا، تـوفر التعليمـات والإرشــادات اللازمسـة)، إســراتيجيات تركـز على إنى الجوانب العاطفيـة للمـتطم (التحفيز الـذاتي، الـدعم والتعزيـز، تحسـين الفعاليـة الذاتيـة، تقليـل عوامـل

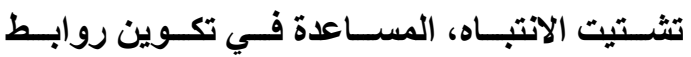
اجتماعيـة ناجحـة وتعزيـز العضـور الاجتمــاعي، تحسين تصـورات المـتعلم نحو بيئسة التعلم، تعزيـز (Chawla \& ) (الثقة بـالنفس والثعور بالإنجاز) Sachdeva, 2018; Wu et al., 2018; Abouammoh et al., 2020; Ruslom \& .Tenlama, 2020)

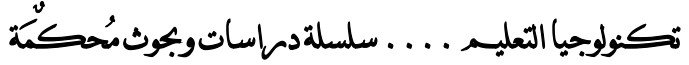


الجمعية المصرية لتكنولوجيا التعليم

التعـاوني عبـر الإنترنـت، أمسا هريساتتي وزمـلاءه

فتوصـلوا فـي Herayanti et al.(2020)

دراستهم إلـى فاعليـة مجتمعـات التـطم القـائم على

الاستقصـاء عبر الإنترنتـت فـي تنميـة مهـارات حل

المشـكلات وتحسـين الاتجاهــات مقارنــة بــالتعلم

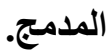

ولــم يقتصـر الأمسر عنــــ الكثـف عـن فاعليـة

مجتمعسـات الـتـعلم القــائم علــى الاستقصــاء عبــر

الإنترنـت؛ بـل اهتمـت بعض الدراسـات بالبحث في

المتغيرات البنائية لتصميم وتظوير تلكك المجتمعات،

Anderson يـث أجسرى أندرسـون (2016)

دراسـة توصل فيها لمجموعة من الإرشـادات التي

توضـح كيفيـة الاسـتفادة مـن تلـك المجتمعـات فـي

Nolan- التطليم والتعلم الرقمي، أما نولان جرانيت Grant (2019)

التوصــيات بثـــأن كيفيــة اســـتخدام مجتمعـــات

الاستقصــاء عبـر الإنترنــت كنمــوذج للتصــميم

Xing and التعليمس، وأجرى تثــاينج وتثثــاو Gao (2018) خصــائص الحــوار عبــر الإنترنـــت واســتمرارية المشـــاركة فــي مجتمعسـات الــتعلم القــائم علـــى

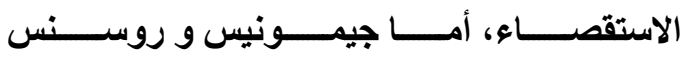
Jimoyiannis and Roussinos (2017) فبحثّا في دراستهما أنمـاط تثــارك المتعلمسين في محررات الويـب التثـاركية Wiki كمجتمـع للتعلم الاستقصــئي عبـر الإنترنـت، واهتمـت دراســة جـو
Akyol and Garrison (2008) مجتمعات الاستقصاء عبر الويب تسـهم بفاعلية في تطوير العضور المعرفي والاجتمـاعي والتدريسي، Kما أثـار كيلز ويلدرم Kilis and Yildirim (2018) أن مجتمعـات الاستقصـاء عبـر الويـب تحقـق نتــائج إيجابيــة بالنسـبة للتنظـيم الـــاتي والمهــارات فـوق المعرفيـة و الدافعيـة، أمـا ميلـر وآخرون Miller et al. (2020) فقد توصلوا إلى وجـود تـأثير إيجـابي لمجتمعـات التتعلم القـائم على الاستقصساء عبر الإنترنت على الاتجـاه نحو التعلم والإنجاز الأكاديمي، وكثفت نتائج دراسـة بوبيسكو و بادى (2020) Popescu and Badea عن تحقيق مجتمعات التعلم القـائم على الاستقصـاء عبر الإنترنت لتأثير إيجابي بالنسبة للحضور الاجتمـاعي والمعرفي، وكذلك دراسة ياندرا وآخرون Yandra et al. (2021) إيجابية بين مجتمعات التعلم القائم على الاستقصساء عبر الإنترنـت وتحسـين الكفـاءة الذاتيـة، وبالتـالي تحسـين جـودة الـتعلم، وتوصـلت دراســة كاسـتل Castle (2014) لوجـود علاقـة بـين مسـتوى المشــاركة فـي بنـاء مجتمعـات الـتعلم القـائم على لــ الاستقصاء عبر الإنترنت ومستوى حاجة المتعلمين للإدر الك، بمـا يحقق الانخراط في التعلم، كمـا أثـار روهايمن وآخرون Rohimin et al.(2020) إلى فاعلية مجتمعات التعلم القائم على الاستقصـاء عبر الإنترنت في تحسين معدلات الإنجاز، مقارنة بـالتعلم 
الجمعية المصرية لتكنـولوجيا التنعليم

إكسـابه مهارات تسـاعده على إدارة تعلمـه في تلك البيئــات وتتظـيم جهـوده ووقتهـه، وكـذلك الاختيـار المناسـب مسن بـين المصــادر التعليميـة المتنوعـة، وتحديد الإستراتيجيات التعليمية الملائمة له، لذا فإن الحاجة تدعو للبحث في إستر اتيجيات تعزيز فاعلية مجتمعــات الاستقصـــاء عبــر الويــب، وإكســـاب المتعلمين المهار ات التي تمكنهم من التظلب على مشــكلات تتــوع البـــائل والخيـــار ات والمصــادر التعليميـة، وكـذلك المشـكلات الناتجــة عـن ارتفـاع مستوى الاستقلالية في التعلم والتطور المستمر في أدوات وتطبيقـات التعلم عبر الويـب، وقضـاء وقت أطول في التعلم عبر الإنترنت، وامتلاك المهـارات اللازمة لإدارة التعلم وتنظيم الوقت والجهد. ويُعد التظيم الذاتي للتعلم معيـارًا للحكم على فاعليـة مجتمعسات التعلم الاستقصـائي عبر الويـب، وخاصة في تطوير الحضور المعرفي والاجتمـاعي، وتحقيق مستوى عالي من الإنجاز الأكاديمي، ويرى دينث وبـاتلر (2018) Dignath and Buttner أن التتظيم الأتي للتعلم يشير إلى قدرة المتعلم على إدراك سياق التعلم و إدارتـه من خـلال مجموعة من العمليـات التي تثضـمن تحديــ الأهـداف وتخطيط التوقعات، والتحكم الذاتي، والتقييم الأتي، والتحفيز الأتي وصولًا لتحقيق الأهداف المطلوبـة، كمـا يؤكد de la Fuente et al. (2020a) الذاتي للتعلم أحد المتنبئات القوية بنجاح المتعلم في اسـتخدامه لإســتراتيجيات التعامـلـ مــع الضــوط
Goh (2020) لفهم طبيعة مجتمعات الاستقصاء عبر الإنترنت، كما أوصست عديـ من الاراسـات بضرورة الاسـتناد إلى النماذج والأطر الإرشـادية لتصميم وبنـاء مجتمعـات

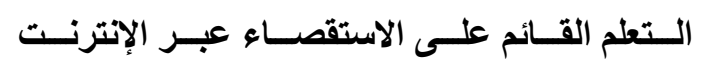
(Bloomberg, 2020; Fiock, 2020; .Heilporn \& Lakhal, 2020) لكن برغم تلك المميزات و الفاعليـة التعليميـة لمجتمعـات الاستقصـاء عبـر الويسب؛ إلا أن هنـاك تحـيـات عديـدة ناتجـة عـن التـداعيات والتحـولات الرقميـة، وانتشـار مجتمعـات التتعم عبر الإنترنت، ومن بين تلك التحديات: تنوع المصسادر والمـوارد المتاحـة فـي بيئـات الـتعلم عبـر الإنترنــ، حاجـة المتعلم إلى الاسـتقلالية والتحفيز الذاتي المستمر، الحاجة لقدر كبيز من الاستقلالية وتحمل مسؤولية الـتعلم، حاجـة المـتـعلم للشـعور بالانتمــاء لمجتمـع التعلم والنشاط والإيجابية وتطوير المعتقدات بشـأن الفوائسد المتحققـة مـن التعلم والقيمـة المُدركـة لـه، وللتعامـل مــع تلــك التحــيات فـإن المــتعلم بحاجـة ضرورية لأن يكون قادرًا على تنظيم وإدارة تعلمهه ذاتيًا 2018; Hatmanto \& Pratolo, 2020) أن التعلم في بيئـات التتعلم عبر الويـب يحتـاج إلىى إدارة ذاتية وتحمل المتعلمين لمسؤولية التعلم، حيث يتمتع المتعلم بمستوى عالي من الاستقلالية وتنوع الخيـارات والبـدائل التعليميـة؛ ممـا يفـرض ضـرورة

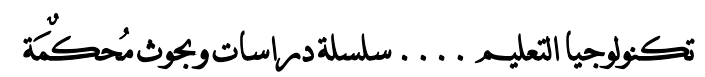


الجمعية المصرية لتكنولوجيا التعليم

التعلم الاستقصائي عبر الإنترنت.

لــا يحساول البحـث الحسالي الاســفادة مـن

المميزات التي تحققها إستراتيجيات التنظيم الذاتي

للتعلم في زيـادة فعاليـة مجتمعـات الاستقصـاء عبر

الويبب، والتفلب على المشـكلات المرتبطـة بهـا -

والتي سبق الإشارة لها-من خلال إسترتيجية تـُمـج

بين إسنتراتيجيتي التنظيم الذاتي للتعلم ومجتمعات

الاستقصــاء عبر الويـب لتنميـة العضـور المعرفي

والاجتمــاعي، والانجـاز الأكـاديمي، والتعامـل مـعـ

الضـغوط الأكاديميـة خـلال مقـرر نظـم إدارة الـتعلم

الإكترونـي لـدى طـلاب الدراسـات العليـا فـي كليـة

التربية.

المحـور الســـاد: العلاقـة بـين متغيـرات

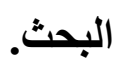

من خلال الدراسات السابقة يتضح ما يلي:

- وجود علاقة بين التطم المُنظم ذاتيًَا وفاعلية

مجتمعـات التعلم القـائم على الاستقصـاء عبر

الويب، (Kilis \& Yildirim, 2016)، كمـا

أن التفـاعلات التعليميـة والاجتماعيـة التـي تتـ

في مجتمعـات التعلم الاستقصـائي عبر الويب

تُسهم في تنميـة مهارات التنظيم الذاتي للتعلم

.(Noloan-Grant, 2019)

وجود علاقة بين مجتمعات التعلم القائم على

الاستقصــاء عبـر الويـب، والأداء الأكساديمي

والرضا عن التعلم والاتجاه نحو التعلم.
الأكاديميـة وتحقيـق الإنجـاز الأكساديمي، وتــتبط

الكفاءة الذاتية في التعلم بقرة المتعلم على التنظيم

الذاتي لتعلمه، حيث إن معتقات المتعلم عن كفاوته الذاتيـة وثقته بذاتـه، تـرتبط بمهاراتـه في تخطيط تعلمه ومر اقبـة معدل تقدمـه وتقييم أدائسه باستمرار وتصحيح مسـار تعلمهـ وتوجيسه جهوده نحو التعلم (Zimmerman \& Schunk, 2011) لودج وآخرون Lodge et al. (2018) أن التنظيم

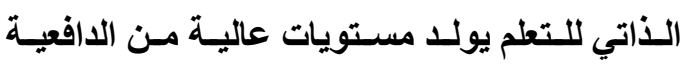
والتحفيز الذاتي والتي تُعالج مشكلة بقاء المتعلمين

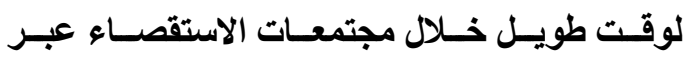

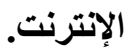

Min and Nasir, وأجرى مـاين ونيزار (2020) دراسـة توصـلت نتائجهـا إلسى أن التنظيم الأتي للتعلم من العوامل الرئيسية التي تسهرم في زيادة فعالية منصات التعلم القائمة على MOOC كما أجرى شو وتثين (2013) Cho and Shen دراسة أسفرت نتائجها عن أن إستراتيجيات التنظيم الـذاتي للتعلم تعـد مـن العوامـل الرئيسـية المنبئسة بنجـاح الطـلاب فـي بيــات الـتطلم عبـر الإنترنـت، وأكدت دراسـات : Kilis \& Yildirim, 2018; de la Fuente et al., 2020-b; Wong et al., 2020; Schumacher \& Ifenthaler, 2021 على مزيــــــن البحـث في كيفيـة تعزيـز

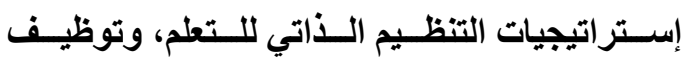
محفزات تطوير تلكك الإستراتيجيات في مجتمعـات 
الجمعية المصرية لتكنولوجيا التعليم

- مستوى الضـوط الأكاديميـة في بيئـات التعلم

عبر الإنترنـت أعلى منهـا في بيئسات التـلم

(Yikealo et al., 2018; التقليديسة

Delfen et al., 2019; Macintyre et

.al., 2020)

في ضوء مـا سبق يتضـح أن العلاقات متداخلـة

بين جميع المتغيرات المستقلة والمتغيرات التابعـة

وكذلكك المتفيرات ويعضـها البعض، ممـا يدعو إلى

دراسـة وكثف نـوع وتأثير ارتبـاط تلكك المتغيرات

ببعضـها البعض، في مجتمعـات التعلم القـائم على لـى

الاستقصاء عبر الويب لدى طلاب الدراسات العليا.

المحور السـابع: التصـور المفـاهيمي للإستراتيجية

القائمة على الامج بين إستراتيجيتي التنظيم الذاتي

للتعلم ومجتمعـات الاستقصـاء عبر الويـب لتنميـة

الحضور المعرفي والاجتمـاعي والإنجاز الأكـاديمي،

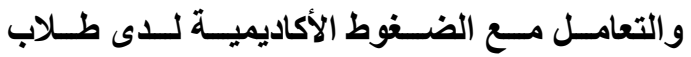

الاراسات العليا في كلية التربية.

أ- التوجــه النظـري لإسـتراتيجية الــدمج بـين

إستر اتيجيتي التظيم الذاتي للتعلم ومجتمعات

الاستقصــاء عبـر الويـب لتنميـة الحضــور

المعرفي والاجتمـاعي والإنجساز الأكساديمي،

و التعامـل مـع الضـغوط الأكاديميـة للدى طـلاب

الار اسنات العليا في كلية التربية.

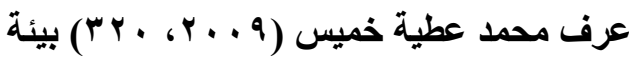

التعلم بأنها كيان ديناميكي، يتكون من مجموعة من

العوامـل و الظـروف والتسـهيلات الماديـة و الفكريـة
- وجـود علاقـة بـين التنظـيم الــاتي للـتعلم

والحضـور المعرفـي والاجتمـــي، وتقليـلـ

(Broadbent \& Poons, العبء المعرفي

2015; Basdogan. 2015; Littlejohn et al., 2016) الــاتي للـتعلم وتحسـين الأداء و الرضــا عـن التعلم والاتجاه نحو بيئات التعلم عبر الإنترنت (Carter et al., 2020; Zheng et al., $.2020)$

- الحضــور الاجتمــاعي مؤشــر منبــئ برضـــا المتعلمين ومستوى الإنجاز الأكساديمي والعب المعرفي ومهارات التفكير Costley Lange, 2016; Richardson et al., ‘2017; Costley, 2019; Nasir, 2020) كما أن الحضور المعرفي مؤشر منبئ بالعبء المعرفي (Kozan, 2016).

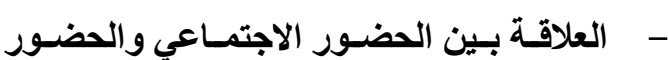
المعرفـي علاقــة تبادليـة Kozan ) .Richardson, 2014)

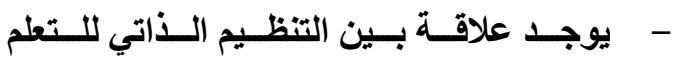
(McClelland et al., والضغوط الأكاديمية .2018; de la Fuente et al., 2020-a) - يـرتبط مستوى الضـغوط الأكاديميـة بمستوى الحضـور الاجتمـاعي للمتعلم في بيئـات التعلم عبر الإنترنت (Yildirim et al., 2017). 
الموجهــة لإجـر اءات و إســتراتيجيات الــتعلم

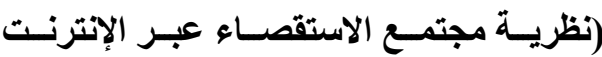

.(COI

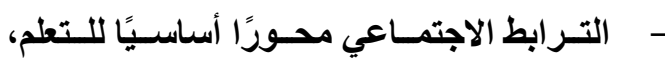
وتنظيم وتصميم الهياكل والمخططات ضرورة لإدرالك المفــاهيم والعلاقــات بـين المتعلمـين لتحقيـق الاعتمــاد الايجـابي المتبـادل (نظريـة (التزابط الاجتماعي). - يحدث التعلم بصـورة أفضل عندما يتم إدراك الكيفية التي يتم بها تهيئة وتصميم التفاعلات الاجتماعيـة و التعليميـة لتمكين المـتعلم مـن المشــاركة الفاعلـة في بنــاء الـتعلم، كمــا أن الحوار و المناقشـة يُسـهمان في بنـاء المعارف التي هى متطلب لبنـاء التطلم (النظريـة البنائية

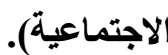
التعلم يحدث مـن خـلال تفاعل ثـلاث مكونـات رئيسية، يجب أن تتكامـل مـع بعضـها لإيجـاد بيــة تعليميـة فعالــة، وهـذه المتطلبـات هـى: التفــاعلات التعليميـة، تصـيم وتتظيم المهـام والأنثطة، فعاليـة المتعلم أو سـيطرة المـتعلم علـى أبعـاد عمليـة الـتعلم، وأنـهـ يجب إدراتك مسـافة التعـاملات عن بعد ومـا يتخللهـا مـن عمليـات/ إجراءات نفسية، وتفاعليـة (نظريـة

$$
\text { (التعاملات عن بعد). }
$$
- يحدث التعلم بثكل أفضل عندما يتم الاهتمـام باحتياجـات المـتطلم، وتلبيـة رغباتـه، وتـوفير
و النفسية والاجتماعية، التي تعطي للموقف التعليمي شخصيته وتفرده، وتؤثر في المتعلم عندما يتفاعل معها، فتساعد في التعلم وتُسهل حدوثه، ويناءً عليه يُعرف مجتمـع التعلم القـائم على الاستقصــاء عبر الويب بأنه بيئة تعليمية ديناميكية تتضمن مجموعة من عمليات التثارك، والتفاعل، والتأمل في التعلم، والمهـــارات فــوق المعرفيــة، لتعزيــز الحضــور المعرفــي، والاجتمـــاعي، والإنجــاز الأكــاديمي ، و التعامل مع الضغوط الأكاديمية، وصولًَ لبناء التعلم وتحقيق أهدافه، كمـا يُعرف نمـوذج مجتمع التعلم القـائم علــى الاستقصــاء عبـر الويـب بأنــه إطـــار مفــاهيمي يتضــمن إرشــادات التصــميم التعليمـي لأنشطة التقلم الاستقصائي عبر الويب، واستخدام مجموعة من إستراتيجيات التعلم المُنظم ذاتيًا، التي تهيــئ للمـتـلم فـرص التفاعـل و التثــارك، لتعزيـز حضوره المعرفي والاجتمـاعي، وإنجازه الأكاديمي، وتُقتلـل مـن الضــوط الأكاديميـة لايسه، فـي إطـــار الفاعلية الذاتية للمتعلم والاعتماد الايجابي المتبادل. ويستمد الإطـار المفـاهيمي لاستراتيجية الـدمج بين إستراتيجيتي التنظيم الذاتي للتعلم ومجتمعات الاستقصــاء عبـر الويـب مرتكزاتـهـ مـن مبـادئ ومضامين عدد من النظريات على النحو الاتي: - المـتعلم بحاجـة لتحقيـق الحضـور المعرفـي، والاجتماعي، والتعليمي، لحدوث التعلم العميق الناتج عن المشاركة الفاعلة في بنـاء التعلم، في ضـوء مجموعـة الإرشــادات والتعليمسات 
الجمعية المصرية لتكنولوهيا التعليم

إدراكها، كلما زاد معدل تحقق التعلم (النظريـة

الآلفــة بيــــه وبـين عناصـر عمليـة الـتـطلم

التواصلية/ الترابطية).

$$
\text { (النظريات المعرفية). }
$$

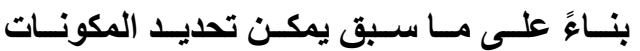

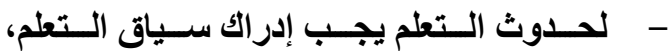

الرئيسية للإطار المفاهيمي لإستراتيجية الدمج بين

وتوضيح أسس واجراءات التعلم (النظريـات

إســتراتيجيتي التنظيم الــاتي للـتـلم ومجتمعسات

(السلوكية).

الاستقصــاء عبر الويـب لتنميـة الحضـور المعرفي

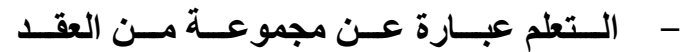

والاجتمــاعي، والإنجــاز الأكـاديمي، والتعامـل مـعـ

والارتباطـات، وتغير في الاستجابات، وكلمـا

الضغوط الأكاديمية من خلال الثكل (\&):

زاد عدد العقد وارتباطها، وتمكن المتعلم من

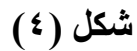

نموذج مجتمع التعلم القائم على الاستقصاء عبر الويب في ضوء إستراتيجيات التنظيم الذاتتي للتعلم

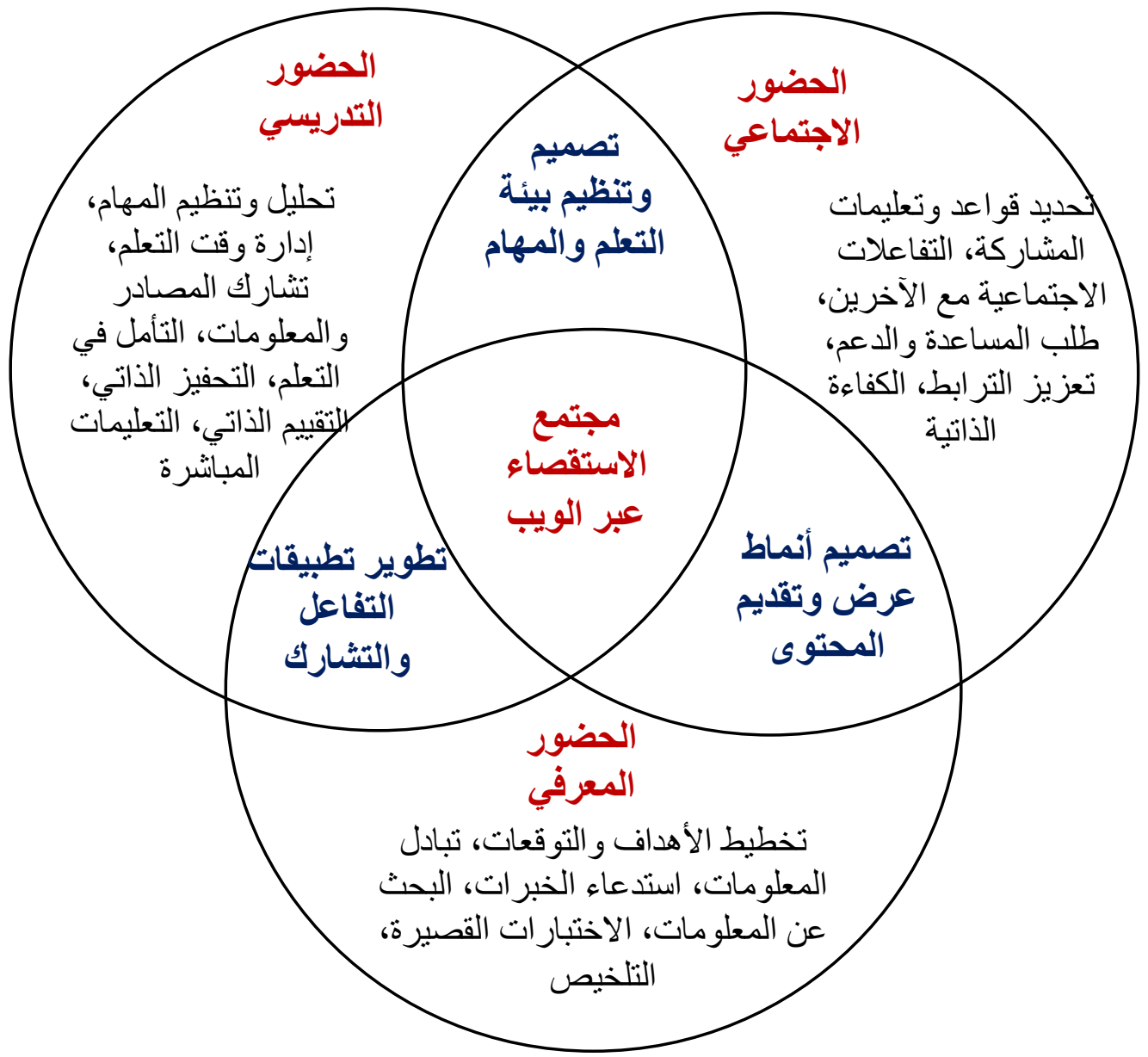


(1) (1) (1)

عناصر الإطار الدفاهييس لإستراتيجية الامج بين إستراتيجيتي التنظيم الذاتي للتعلم ومجتمعات الاستقصاء عبر الويب، والأدوات المرتبطة اللازمة لبناء كل عنصر

\begin{tabular}{|c|c|c|}
\hline 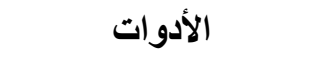 & الإستر اتيجيات / الأنشطة الاستقصائية & العناصر \\
\hline الصـفحات الشخصــية & \multirow{22}{*}{ 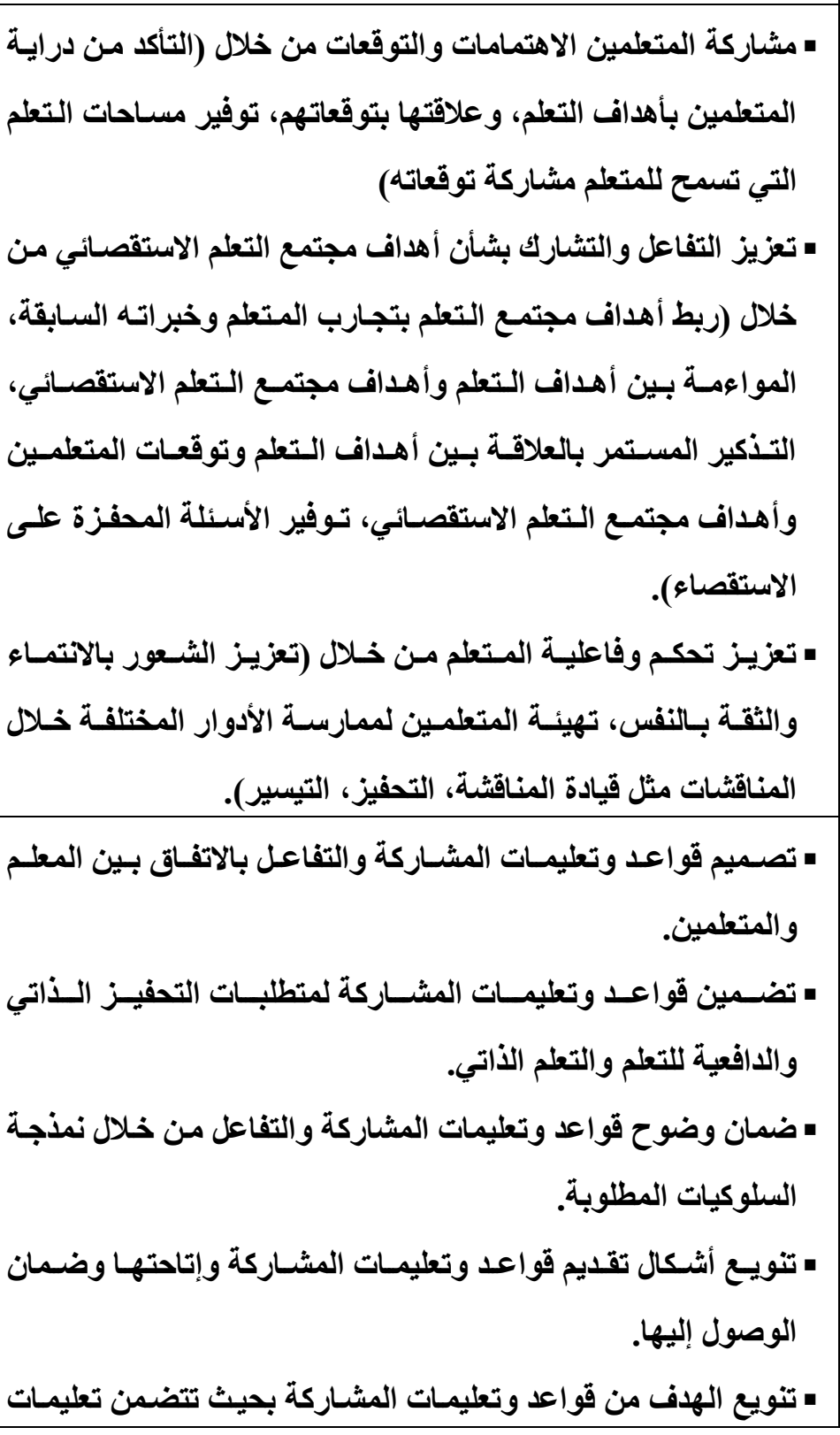 } & \multirow{13}{*}{ 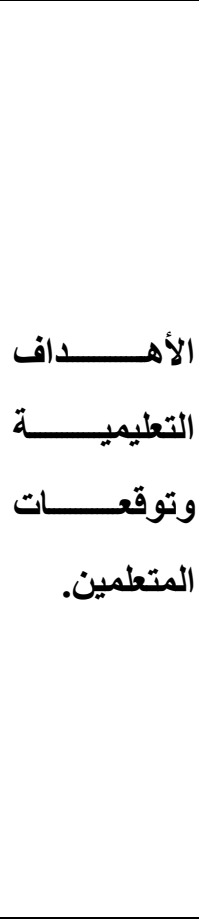 } \\
\hline للمتعلم، رسائل التذكير & & \\
\hline & & \\
\hline & & \\
\hline المنشـورات في لوحسة & & \\
\hline المناقشــات أو الــويكي & & \\
\hline أو المدونات. & & \\
\hline أدوات إنشـــاء خــرائط & & \\
\hline 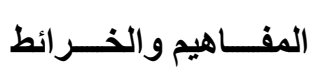 & & \\
\hline \multirow[t]{4}{*}{ الذهنية } & & \\
\hline & & \\
\hline & & \\
\hline & & \\
\hline الاعلاتــــات، مقـــاطع & & \\
\hline الفيــــــيو، لوحــــــات & & \\
\hline & & \\
\hline الــــويكي، الجلســــات & & وتعليمـــــــات \\
\hline الافتر اضــية، روابــط & & التشـــــــــــو \\
\hline للــــــعم والمســــاندة، & & \\
\hline مخططــــات معرفيـــة، & & \\
\hline & & \\
\hline & & \\
\hline
\end{tabular}


الجمعية المصرية لتكنـولوجيا التعليم

\begin{tabular}{|c|c|c|}
\hline الأدوات & الإستر اتيجيات / الأنشطة الاستقصائية & العناصر \\
\hline & ه م توفير الإرشادات بالّهد النهائي وأخرى موجهة لإجراعات تتفيذ التعلم. & \\
\hline 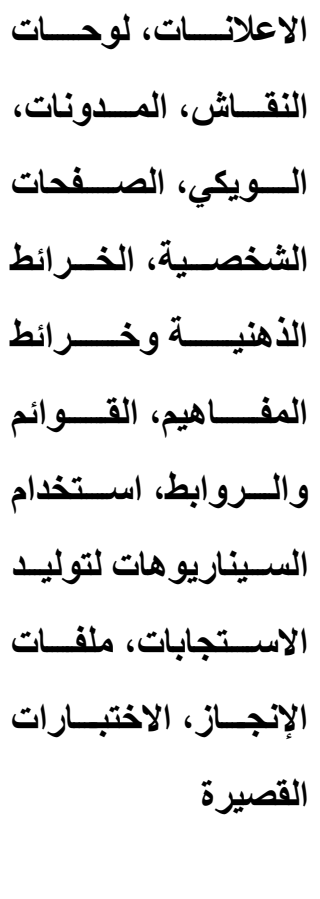 & 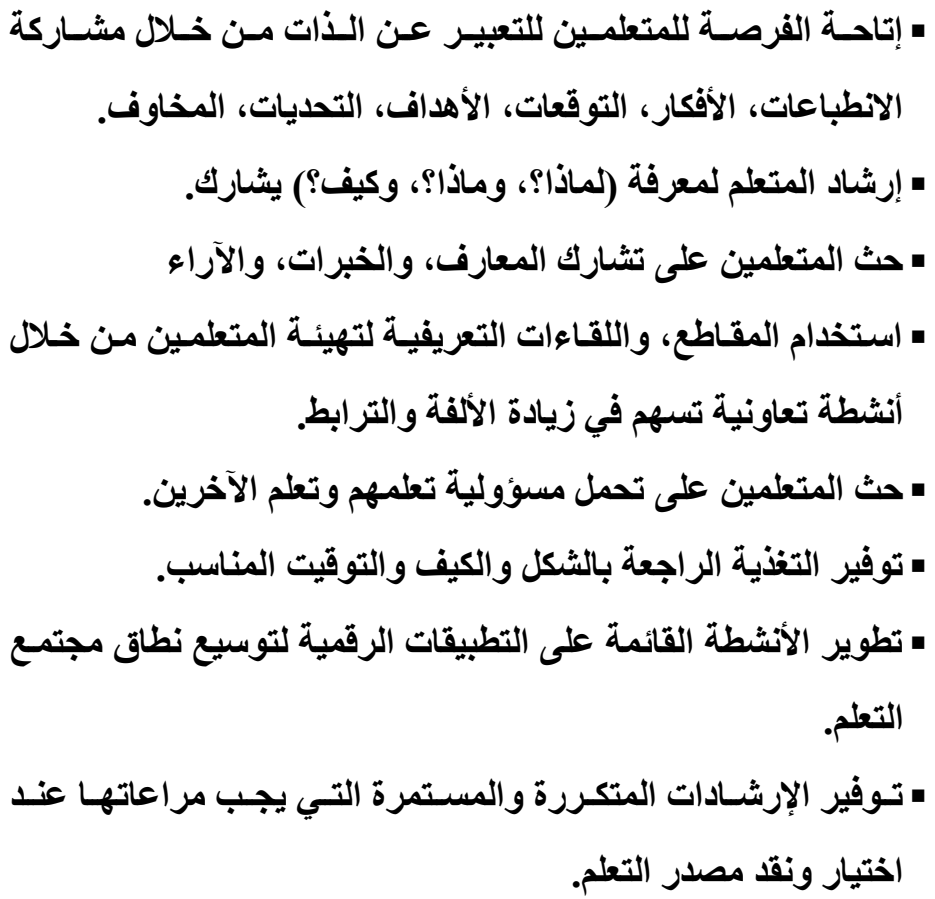 & وأدوات مســـــات \\
\hline 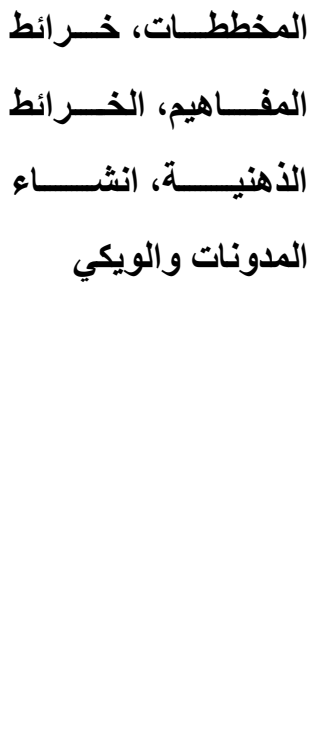 & 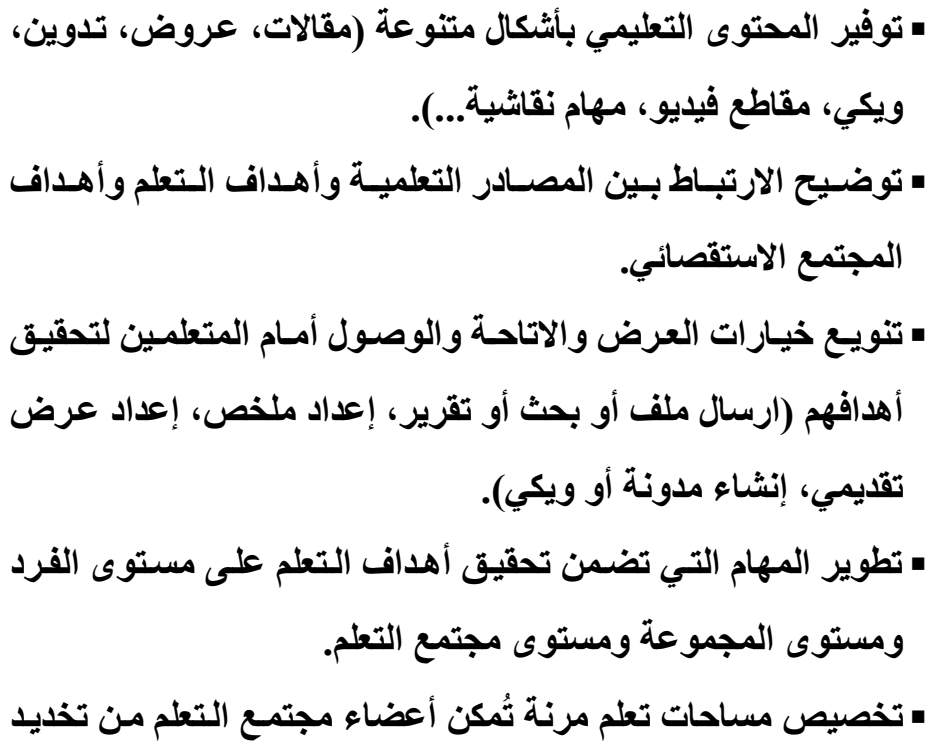 & 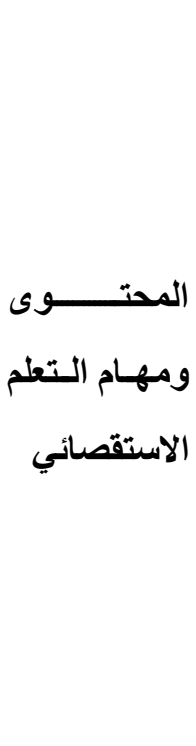 \\
\hline
\end{tabular}


الجمعية المصرية لتكنولوجيا التعليم

\begin{tabular}{|c|c|c|}
\hline الأدوات & الإستر اتيجيات / الأنشطة الاستقصائية & 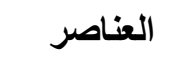 \\
\hline & 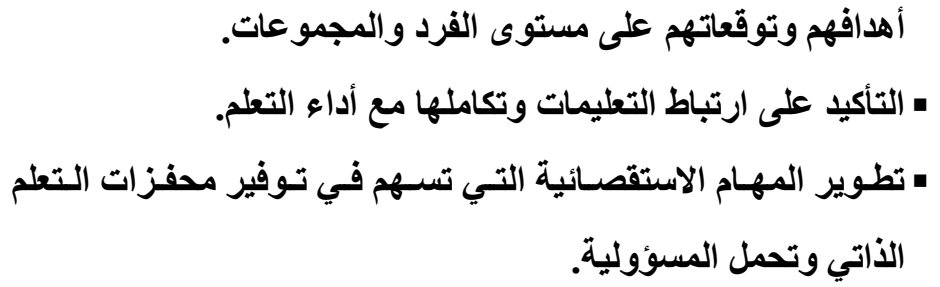 & \\
\hline 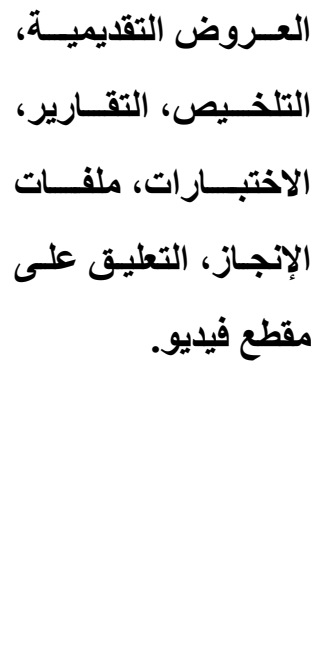 & • - ـ ـ إتاحة الفرصة للمتعلمين لتقييم أدائهم والتأمل في التعلم. & التقلم والتقلقييم فـــي \\
\hline
\end{tabular}

الويـب (محمـــ الاســوقي، Y I ب r، محمــ عطيـة

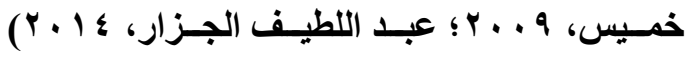
أستقر الرأي على اختيار نموذج الجزار في نسخته الانجليزية (El-Gazzar, 2014) الموضح بالشكل (0)، مع مراعاة دمـج بعض الخطوات وفق أهداف و إجر اءات البحث.
بـ نموذج التصميم التعليمي لمجتمع التعلم القائم على الاستقصساء عبر الويب لتطوير الحضور المعرفـي والاجتمـاعي والإنجـاز الأكساديمي، والتعامـل مـع الضـفوط الأكاديميـة للدى طلاب الدراسات العليا في كلية التربية. مـن خـلال الاطلاع على بعض نمـاذج التصـميم التعليمسي التـي اهتمـت بتطـوير بيئـات التتعلم عبر 
الجمعية المصرية لتكنـولوجيا التعليم

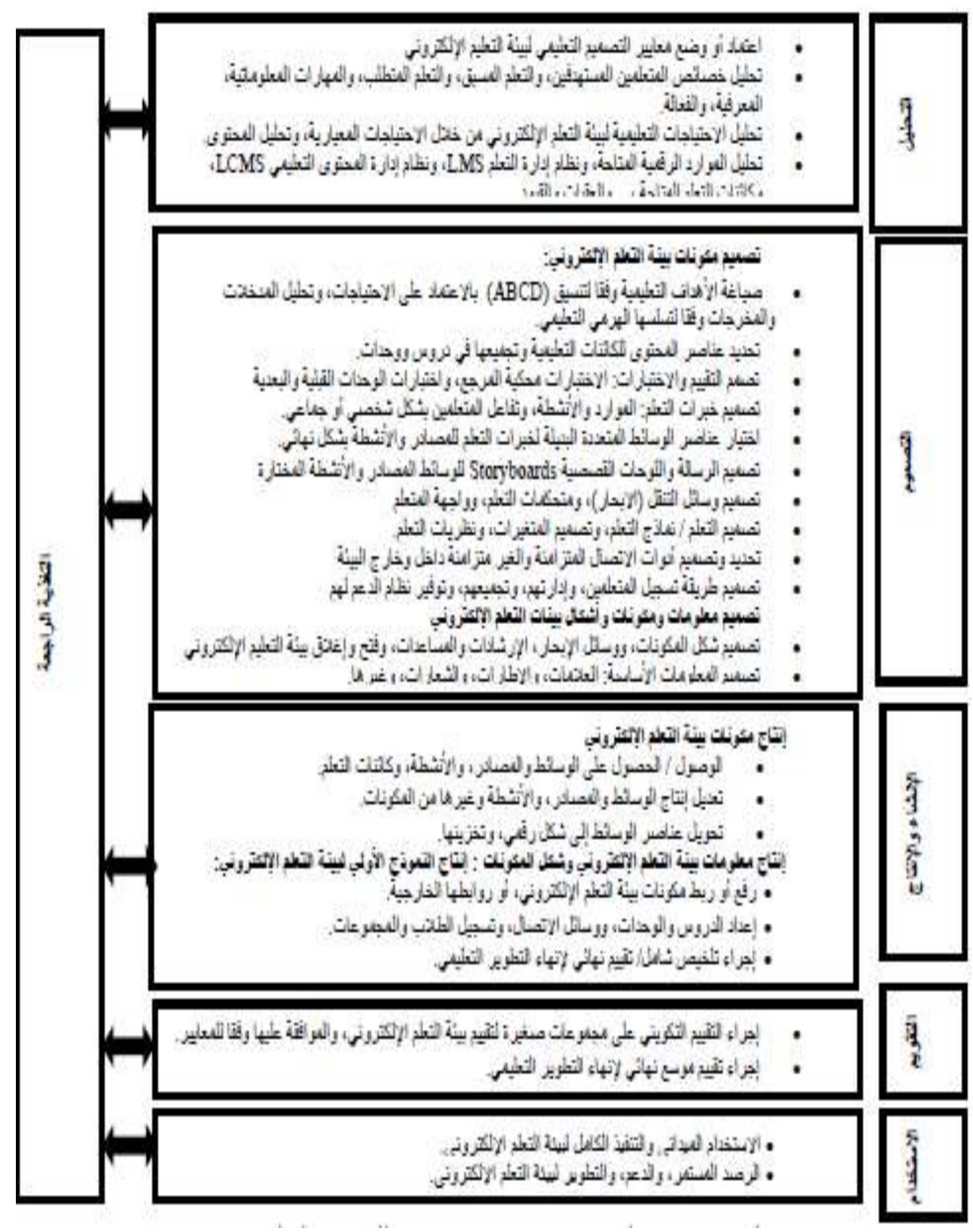

شكل (0)

نصوذج عبد اللطيف الجزار (El-Gazzar, 2014) للتصميم التعلييس 


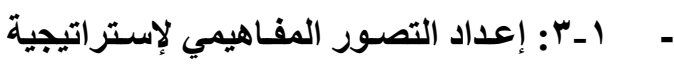
الامج بين إستراتيجيتي التنظيم الذاتي للتعلم

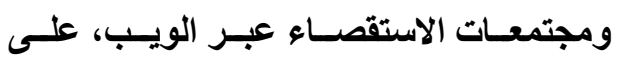
الحضـور المعرفي، والاجتمـاعي، والإتجـاز الأكـاديمي، والتعامـل مـع الضـفوط الأكاديميـة خلال مقرر نظم إدارة التعلم الإكترونسي للى الدي طلاب الدراسات العليا في كلية التربية.

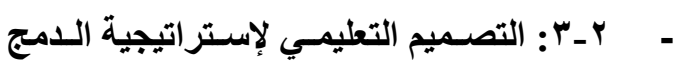

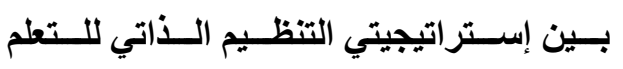
ومجتمعـات الاستقصــاء عبـر الويـب، على لــ الحضـور المعرفـي، والاجتمــاعي، والإنجـاز

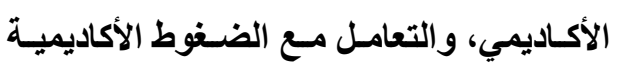
خلال مقرر نظم إدارة التطم الإكترونسي لدى طلاب الدراسـات العليـا في كليـة التربيـة، في ضـوء خطــوات التصــميم التعليمسي لنمـوذج

$$
\begin{aligned}
& \text { الجزار (צ ا • Y). } \\
& \text { - تصميم أدوات البحث. } \\
& \text { ـ تجربة البحث. } \\
& \text { ـ التحليل الإحصائي للبيانات. }
\end{aligned}
$$

- عرض نتائج البحث ومناقشتها وتفسير ها.

ـ تقديم التوصيات والمقترحات المناسبة.

$$
\text { وذللك على النحو الآتي: }
$$

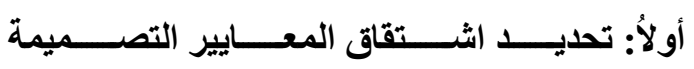
للإستراتيجية القائمسة على اللامج بين إستراتيجيتي التنظيم الذاتي للتعلم ومجتمعسات الاستقصساء عبر لإنسر الويـب، علـى الحضــور المعرفـي، والاجتمــاعي،

\section{الإجمراءات المنهمية لابمث}

نظرًا لأن البحث الحالي يهاف إلى الكشف

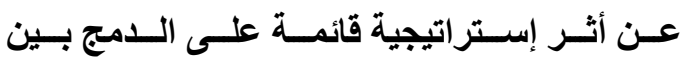
إسـتراتيجيتي التنظيم الـذاتي للـتعلم ومجتمعسات الاستقصـاء عبر الويـب، على الحضـور المعرفي،

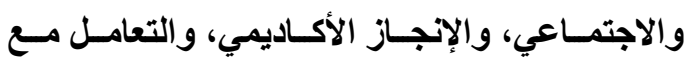
الضـغوط الأكاديميـة خـلال مقـرر نظـم إدارة الـتعلم الإكترونـي لـدى طـلاب الدراسـات العليـا في كليـة التربية؛ لذلك فقد قام الباحث بـالإجراءات المنهجية الآتية: - الــتقاق المعسيير التصــميمة للاسـتراتيجية القائمسة على اللامج بين إستراتيجيتي التنظيم الـــاتي للـتعلم ومجتمعــات الاستقصــاء عبـر الويب، على الحضور المعرفي، والاجتمـاعي، والإنجـاز الأكساديمي، والتعامـل مـع الضــوط

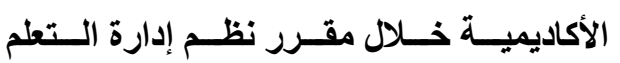
الإكتروني لاى طلاب الاراسات العليا في كلية

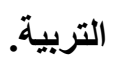
- على اللدمج بين إستراتيجيتي التنظيم الذاتي للتعلم ومجتمعات الاستقصاء عبر الويب، على الحضـور المعرفـي، والاجتمــاعي، والإنجـاز الأكـاديمي، والتعامـل مـع الضــوط الأكاديميـة خلال مقرر نظم إدارة التطلم الإكترونسي للدى طلاب الاراسات العليا في كلية التربية) مرورًا

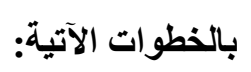


الجمعية المصرية لتكنـولوجيا التعليم

- تحديد الهدف من قائمـة المعاييز: والذي تمثل فـي تحديــــ متغيــرات أو عوامـل التصــميم التعليمي والتقتي لمجتمعات التعلم الاستقصائي عبـر الويسب، فـي ضــوء متطلبـات تطــوير الحضــور المعرفـي، الاجتمــاعي، والإنجــاز الأكـاديمي، والتعامـل مـع الضـغوط الأكاديميـة لاى طلاب الار اسات بكلية التربية. - إعداد الصور الأولية لقائمة المعايير، حيث تم اسـتخلاص مجموعـة مسن المعـايير الرئيسية والمؤشـرات الفرعيـة التـي يمكن مسن خلالهـا قيـاس مـدى تـوفر المعـايير الرئيسـية، حيـث تضمنت الصور المبئية ثماتية معايير رئيسية تُقاس باستخدام (V 9 ) مؤشرًا. عرض الصـور المبلئيـة لقائمسة المعايير على الخبراء والمتخصصين، لضمان دقة المعايير

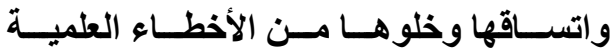
واللغوية، ووضوح المؤشرات التي ثُّتساس من خلالها المعاييز الرئيسية، وأيضًا التحقق من ارتباط المؤشرات بالمعيـار الذي تنتمـي إليـه، وفي ضوء ملاحظـات وآراء المقيمين والذين بــنح عـدهم إحـدى عثـر محكمًا، تـم إعـادة صياغة بعض المؤشرات وذلتك لعدم وضوحها، اسـتبدال بعـض المؤشــرات لعــدم ارتباطهــا بالمعيـار الذي تقيسـه، إضـافة مؤشـر لكل من المعيــار الأول والمعيــار الثالــــ، وتفصــيل المعيار التاسـع بحيث يتم تخصيص مؤشرات
والإنجاز الأكاديمي، والتعامل مع الضغوط الأكاديمية خلال مقرر نظم إدارة التعلم الإكتروني للى طلاب الاراسات العليا في كلية التربية. تـرتبط جـودة التصــميم التعليمـي لمجتمعـات الاستقصــاء عبــر الويــب بالة لـدرة علــى إتاحــة إســتراتيجيات وأنشــطة ومهـــام تعليميــة تهـيء للمتعلمـين فـرص الاستقصــاء والبحـث وتثــارك المعارف وبناءها، في ضوء متطلبات التعلم الرقمي، كــا جـاء الاهتمــام بالتصـميم التعليمـي لمجتمعـات التعلم الاستقصسائي عبر الويـب، كنتيجـة للتحديات والتطورات الراهنة التي فرضت التوجهـ نحو بيئـات التعلم عبر الويب، مما ترتب عليه الحاجة إلى زيادة التفاعلات الاجتماعية وإدراك سياق التعلم والعلاقات بين المفـاهيم والمحتـوى الرقمي، ولإعداد معـاييز تصميم إستراتيجية الدمج بين إستراتيجية التنظيم الأاتي للتعلم ومجتمعات الاستقصاء عبر الويب، تم اتباع الخطوات الآتية: - الاطــلاع علـــى الدراســات الســـابقة وقـوائم المعايير التي تناولت تصميم بيئسات التعلم عبر (Kumar \& Ritzhaupt, 2014; الويب Rogers \& Van Haneghan, 2016; Suarez et al., 2018; Tao \& Zhang, 2018; Baldwin \& Ching, 2019) حيـث تـم تحديـ العوامـل الرئيسـية المرتبطـة بالتصـيم التعليمسي والتقـي لمجتمعـات التعلم الاستقصائي عبر الويب.

تصكنولوجيا التعليـ . . . . سلسلةدماساتوبجوثمُحهمَة 
الجمعية المصرية لتكنولوجيا التنعليم

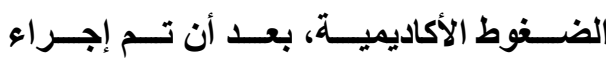

التعديلات التي أقترحها المحكمين، تم التوصل

للصسورة النهائيسة للقائمـة، والتـي تكونـت مـن

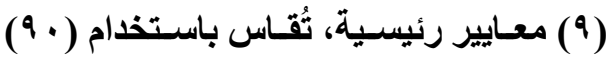

مؤشرًا (ملحق ())، كمـا هو موضـح بالجدول

$:(r)$

$$
\text { الكـل مكــون مــن مكونــات نـــوذج الــتعلم }
$$

- الصورة النهائيسة لمعـيير تصميم إستراتيجية الامج بين إستراتيجيتي التنظيم الذاتي للتعلم ومجتمعـات الاستقصـاء عبـر الويـب لتنميـة الحضـور المعرفـي والاجتمـاعي، وتحسـين الإنجاز الأكاديمي، وتنمية مهارات التعامل ميع

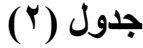

المعايير الرئيسية لتصديم إستراتيجية الامج بين إستراتيجيتي التظيم الذاتي للتعلم ومجتمعات الاستقصاء عبر

\begin{tabular}{|c|c|c|}
\hline عدد المؤشرات & المعيار & م \\
\hline$\wedge$ & دعم المواطنة الرقمية لدى فئات المستفيدين ذوي العلاقة & 1 \\
\hline$\wedge$ & الارتكاز لمبادئ التعلم المستمر والتعلم مدى الحياة، والنظريات ذات العلاقة & r \\
\hline 9 & تصميم الهياكل، التعليمات، الإرشادات & $r$ \\
\hline 9 & تصميم فاعلية المتعلم وسيطرته على التعلم & $\varepsilon$ \\
\hline$v$ & تصميم التحفيز أو الاسئلة الاستقصائية & ○ \\
\hline 1. & تصميم أنشطة ومهام التعلم الاستقصائي عبر الويب & 7 \\
\hline ir & تصميم أدوات وتطبيقات التعلم الاستقصائي عبر الويب & $\checkmark$ \\
\hline$\wedge$ & تصميم أساليب تقييم ومراقبة التعلم & $\wedge$ \\
\hline rr & تصميم المعايير التخصصية لمكونات مجتمعات التعلم الاستقصائي عبر الويب & 9 \\
\hline
\end{tabular}
الويب والمؤشرات المرتبطة بها

إدارة التعلم الإكترونسي للاى طلاب الدراسـات العليـا في كلية التربية) مرورًا بالخطوات الآتية: يهرف البحث إلى بنـاء إستراتيجية قائمسة على الــدمج بـين إســتراتيجيتي التنظسيم الـذاتي للـتعلم
ثانيًا: تصميم المعالجة التجريبية (إستراتيجية قائمسة على اللامج بين إستراتيجيتي التظيم الذاتي للتعلم ومجتمعـات الاستقصـاء عبر الويب، على الحضور المعرفــي، والاجتمـــاعي، والإنجـــاز الأكـــاديمي، والتعامـل مـع الضـغوط الأكاديميـة خـلال مقرر نظم 
الجمعية المصرية لتكنـولوجيا التهليم

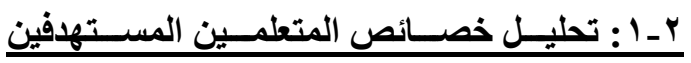
والتعلم المسبث والتعلم المتطلب:

تكونت عينة البحث من طلاب الدراسـات العليا بكلية التربيـة جامعة نجران، وعددهم (Y) وهم يلرسـون مقـرر نظـم إدارة الـتعلم الإلكترونـي في المسـتوى الثاني/السـنة الأولـى، ولـديهم المعسارف و المهــارات الأسـاسـية لاسـتخدام نظــام إدارة الـتعلم Blackboard المرتبطة باستخدام أدوات المدونات والويكي ضمن نظام البلاك بورد، ولديهم الرغبة والاستعداد للتعلم فـي بيئـات الـتعلم عبـر الويـبــ نظـرًا للمتغيـرات المرتبطـة بجائحسة كورونــا (COVID-19)، مـع العلـم أن (IV ) منهم يعمـل في مهنـة التعليم ـ كمـا أظهرت الدراسـة الاسـتطلاعية، ونتـائج الاراسـات السـابقة وجـود حاجـة ملحسة إلى تطـوير الحضـور المعرفي والاجتمـاعي، وتحسين الإنجاز الأكاديمي، وتطـــوير إســـتراتيجيات التعامـلـل مـــع الضـــوط الأكاديميـة لـدى طـلاب الدراسـات العليـا، مـن خـلال تطوير مجتمـع للتتطم القـائم على الاستقصـاء عبر الويب مدعوم بإستراتيجيات التعلم المُنظم ذاتيًا؛ لمـا قد يحدثه من تأثثير إيجابي على الإنجاز الأكاديمي وتطـوير مهــارات مواجهــة الضــوط الأكاديميـة، وكـذلك حاجـة طـلاب الدراسـات العليـا إلـى تطـوير مهـــار اتهم المرتبطــة بـاســتخدام أدوات وتطبيقــات تصميم وتطوير مجتمعات التعلم الاستقصسائي عبر

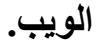

ومجتمعـات الاستقصـاء عبر الويب، والكثـف عن أثرهــا عـــى الحضــور المعرفـي، والاجتمــاعي، والإنجاز الأكاديمي، والتعامل مع الضغوط الأكاديمية خلال مقرر نظم إدارة التعلم الإكتروني لدى طلاب الار اســات العليـا (الماجستير- المسـتوى الثـاني/ السنة الأولى) في كلية التربية ، وتم تصميم خطوات هـذه الإســتراتيجية، فـي ضـوء نمسوذجي الجـزار، وجاريسون وان (et al., 2001) وفيما يلي الخطوات الإجرائية التي قام بها الباحث في كل مرحلة من المر احل بعد عمل التعديلات اللازمة في ضوء طبيعة البحث: ا ـ مرحلة الاراسة والتحليل: اشتملت هذه المرحلة الإجراعات التالية: 1 ـ1 : اشـتقاق أو وضــع معـاييز التصـميم التعليمـي إستر اتيجية الدمج بين إستراتيجيتى التتظيم الذاتى للتعلم ومجتمعات الاستقصاء عبر الويب: تـم التوصـل لقائمــة معــييز التصـميم التعليمـي لإستراتيجية الامج بين إستراتيجيتي التتظيم الذاتي للتعلم ومجتمعـات الاستقصـاء عبـر الويـب لتتميـة الحضور المعرفي والاجتماعي، والإنجاز الأكاديمي، و التعامـلـل مـــع الضــغوط الأكاديميــة لـــى طـلاب الدراسـات العليـا فـي كليـة التربيـة، في (أولَا مـن خطوات البحث)، والقائمة اشتملت على (9) معايير رئيسية، ثُقاس باستخدام ( • 9) مؤشرًا ملحق (1). تصكنولوجيا التعليـم . . . . سلسلةدماساتوبجوثمُحصكمة 
الجمعية المصرية لتكنولوجيا التعليم

- الحاجـة لتطـوير مهـارات التعامـل مـع الضـغوط

الأكاديمية.

- الحاجـة لتطـوير إسـتراتيجيات التتظيم الـذاتي

للتعلم في مجتمعات التعلم عبر الويب.

عــا : تحليـل مصــادر الـتعلم الإكترونيـة المتاحـة،

ونظام إدارة التعلم LMS و المحددات و القيود:

نظـــرًا لأن نظـــام إدارة الـــتطلم الإكترونــــي

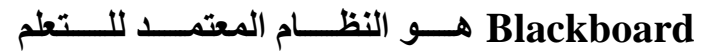

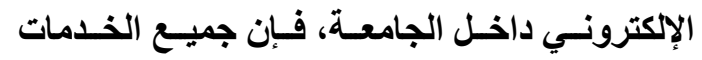

والامكانات المرتبطة به متوفرة لدى الطلاب، حيث

يحصل كل طالب على حسـاب خـاص بـه على الـ

Blackboard وبالتـالي إتاحسة النظــام وســهولة

الوصـول إليـهـه وتــوفر الأدلـة الارشــادية اللازمــة

لاستخدامه، كمـا أن شـبكة الإنترنت متاحسة بكفـاءة

للطـلاب، وتــم التحقـق مـن تـوفر جهــاز كمبيـوتر

محمول أو كمبيوتر مكتبي أو جهاز لوحي أو الجوال

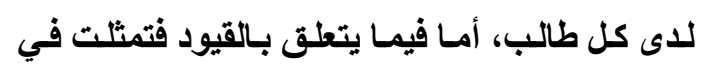

عدم تخصيص مسـاحة لكل طالب لإنثـاء مجتمـع

التعلم الخاص به، وذلك وفق أنظمة الجامعة، لكن تم

التظلب على ذلك بمخاطبة عمـادة التعلم الإكترونسي

لإتاحة خاصية قيام الطالب بإنشـاء وتطوير مجتمـع

تعلم استقصسائي عبر الإنترنت خـاص بـه، حيث تم

إعطــاء الصــلاحيات لكـل طالــب، لتصــبح لايــهـ

صـلاحيات أستـاذ المقـرر وبالتـالي إنثــاء وتطـوير

مسـاحات التتطم واسـتخدام أدوات إنشــاء مجتمعـات

$$
\text { التعلم الاستقصائي. }
$$

r-1 : تحديد الاحتياجات التعليمية:

تــم تحديـــ الاحتياجـات التطليميـة فـي ضـوء

متطلبات مقرر نظم إدارة التعلم الإكتروني، وخاصـة

مــا يتعلـق منهــا بإسـتراتيجيات تعزيـز الحضـور المعرفي والاجتماعي، والإنجاز الأكـاديمي، وتطوير

مهارات التعامل مع الضـوط الأكاديميـة، ومهارات استخدام أدوات إنثاء مجتمعـات التعلم الاستقصسائي عبر الويـب مثُل: المنتـديات، المـدونات، الـويكي، تقيّيم الأقران، إنثـاء المهام، تكوين المجموعـات، نماذج تصميم الأنشطة الاستقصائية عبر الإنترنت،

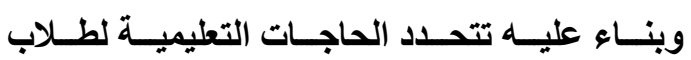
الاراسات العليا في القائمة الآتية: - الحاجـة لمعرفـة المفـاهيم المرتبطـة بـنظم إدارة التعلم الإكترونية. - الحاجــة لمعرفــة مكونـــات نظـــم إدارة الــتعلم الإكترونية والخدمات أو المميزات التي تقدمها. - الحاجــة لمعرفــة تصــنيف نظـــم إدارة الــتعلم الإلكتروني. - الحاجة لمعرفة معايير تصميم وتطوير واختيار نظم إدارة التعلم الإكتروني. - الحاجة لإتقان مهارات تصميم وتطوير مجتمعات التعلم الاستقصائي عبر الويب. - - الحاجـة لاكتسـاب مهارات تطبيق إستراتيجيات

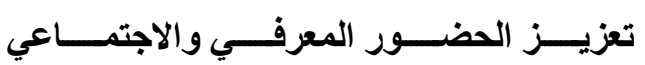
والتدريسي. 
الجمعية المصرية لتكنولوجيا التعليم

- -

نظـم إدارة الـتعلم الإكترترونيـة والخـدمات التــي

يقدمها.

التعلم الاستقصائي عبر الإنترنت.

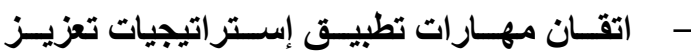
الحضور المعرفي والاجتماعي والتدريسي. - - تطوير مهار ات التعامل مع الضغوط الأكاديمية. - - تطوير إسـتراتيجيات التنظيم الذاتي للتعلم في مي مجتمعات التعلم عبر الويب.

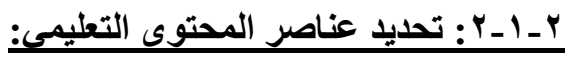

تم تحديد قائمـة موضوعات المقرر في ضـوء الأهــاف التعليميـة، لتثـــل القائمــة الموضـوعات الآتية:

- المفاهيم المرتبطة بنظم إدارة التعلم الإكترونية. - المفـاهيم المرتبطة بمجتمـع التعلم الاستقصـائي

$$
\text { عبر الإنترنت. }
$$

- - أنواع نظم إدارة التعلم الإكتروني. - معايير تصميم وتطوير واختيار نظم إدارة التعلم

$$
\text { الإلكتروني. }
$$

- أدوات وتطبيةــــات إنشــــاء مجتمــــع الـــتـلم

$$
\text { الاستقصائي عبر الإنترنت. }
$$

- مهـارات اسـتخدام كل مكون مـن مكونــات نظم إدارة التعلم الإكترونية والخدمات التي يقدمها. - - تصــميم وإنتـــاج وتطــوير مجتمعــات الــتعلم الاستقصائي عبر الإنترنت. r- ب - مرحلة التصميم: اشتملت على الإجراءات الآتية:

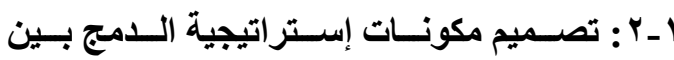
إســتراتيجيتي التنظـيم الـــاتي للـتعلم ومجتمعسات الاستقصاء عبر الويب مرورًا بالخطوات الآتية:

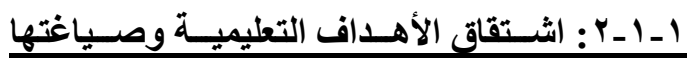
بنموذج ABCD: في ضـو نتـائج تحديـ الحاجـات التعليميـة، تم تحديــ الهــف العـام والأهــاف التعليميـة لمجتمـع التعلم الاستقصـائي عبر الويب، حيث تمثل الهدف العـام في" تطوير الحضـور المعرفي والاجتمساعي، والإتجـاز الأكـاديمي، وتطوير مهـارات التعامـل مـع الضغوط الأكاديمية للدى طلاب الدراسـات العليا من خـلال إكســابهم مهـــارات تطـوير مجتمــع الـتعلم الاستقصــــائي باســــتخدام نظـــــام إدارة الــــتملم

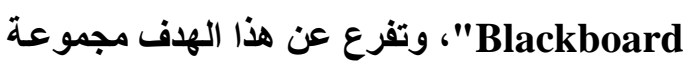
أهداف فرعية كما يلي: - معرفـة المفــاهيم المرتبطـة بــنظم إدارة الـتـعلم الإكترونية. - معرفــة المفــاهيم المرتبطـــة بمجتمــع الــتعلم الاستقصائي عبر الإنترنت. - - تمييز أنواع نظم إدارة التعلم الإكتروني. - معرفة معايير تصميم وتظوير واختيار نظم إدارة التعلم الإكتروني. - - التعرف على أدوات وتطبيقـات إنشــاء مجتمـع التعلم الاستقصائي عبر الإنترنت.

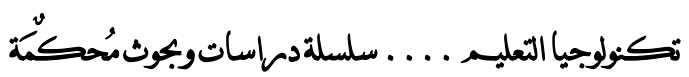


الجمعية المصرية لتكنولوجيا التعليم

التـطلم الخـاص بـه، وأخـرى جماعيـة والتـي يقـوم الطالب بالتشارك في تنفيذها مع زملاءه في مجتمع الـتعلم الاستقصــائي العـام الخــاص بـالمقرر، وتــم مراعاة تتويع أدوات تقايم وعرض الأنشطة والمهام الاستقصائية لتشمل ( أنثطة قائمسة على المنتديات أو لوحسات النقـاش، أنثـطة قائمسة على المـدونات، أنشطة قائمة على الويكي، أنشطة قائمة على البحث

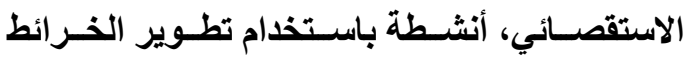
الأهنيـة)، وروعسي تنويـعِ خبـرات الـتعلم لتشــل: زيارة روابط صفحات، الاطلاع على مقاطع فيديو، الاطلاع على أدلة ارشادية، عروض تقديمية، صور ورسومات، ملفات PDF للمحتوى التعليمي، زيارة مـدونات أو ويكـي، وتضـــت الأنشـــة والمهــام الاستقصـائية أيضـاً: الاجابـة على تســاؤلات، إعداد ملخصـات، إعداد مقـاطع فيـديو تعريفيـة، تحليل أو التعليق على محتوى أو مقطع فيديو.

هـ Y_l : اختيار بائل عناصر الوسائط التعليمية: تــم تعليــــ المحتــوى التعليمـي، والعـروض التعليمية والأدلة الارشادية ومقاطع الفيديو اللازمـة فـي ضــوء أهــافـ الــتعلم، وكــللك المحاضــرات المسـجلة، والجلســات الافتراضـية التـي يحتاجهـا الطلاب.

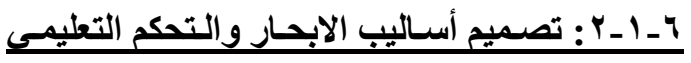
وواجهة التفاعل. نظــرًا لأن تطــوير إســتراتيجية الـــــج بـين

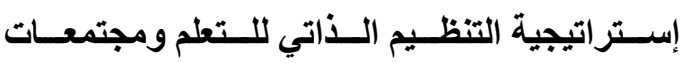

- - إســـتراتيجيات تعزيـــز الحضـــور المعرفــي

$$
\text { والاجتماعي والتدريسي. }
$$

- مهارات التعامل مع الضغوط الأكاديمية. - -

$$
\text { التعلم عبر الويب. }
$$

وتم توزيع تلك الموضوعات على أنثطة التعلم

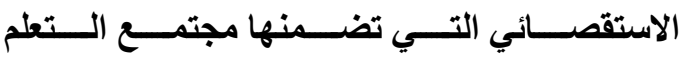
الاستقصائي للمقرر، مع بيان المصادر ذات العلاقة.

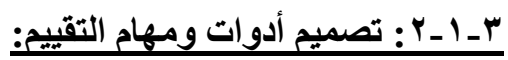
تـم تصـميم أنشـطة ومهـام التقيـيم فـي ضـوء الأهداف التعليميـة والتـي اشـتملت على (اختبـارات قصيرة، تنفيذ مهام، اختبارات عملية، اختبار نهائي للمقرر، مقيساس للحضـور المعرفي والاجتمـاعي، مقيـاس التنظـيم الــاتـي للـتعلم، مقيـاس الضـغوط الأكاديمية في بيئات التعلم عبر الويب) والتي سيرد تفصيلها لاحقًا في أدوات البحث.

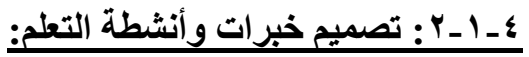
من خلال الاطلاع على بعض نماذج بنـاء أنثطة ومهـام التعلم الاستقصسائي، تم استخلاص نمـوذج يتضــمن مجموعـة مـن العناصـر التـي يجـب أن يتضمنها النشاط الاستقصائي عبر الويب (ملحقץ)،

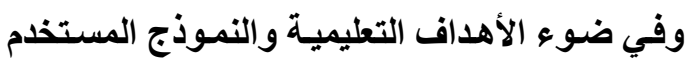
تـم تصــميم الأنثـطة و المهـام الاستقصـائية عبـر الويب، كمـا تـم مراعـاة التنويـع بـين أنشطة التعلم الفرديـة والتـي يقـوم الطالـب بتنفيذها في مجتمـع 
الجمعية المصرية لتكنولوجيا التعليم

الاستقصاء عبر الويب في البحث الحسالي قائم على

اسـتخدام نظـام إدارة التعلم Blackboard ضـمن

مقرر نظم إدارة التعلم الإكتروني، لذا يوجد صفحة

مخصصـة للمقـرر، وقـام الباحـث بإعـادة تهيئسة

الصفحة الرئيسية للمقرر بمـا يناسب طبيعة البحث

والهدف من تطوير مجتمع التعلم الاستقصائي، حيث

تم إعـادة تهيئة القائمسة الرئيسية للمقرر، وتجهيز

الـــروابط للصــفـحات الرئيســية لأدوات الـــتـلم

الاستقصائي التي تم استخد/مها في البحث الحالي.

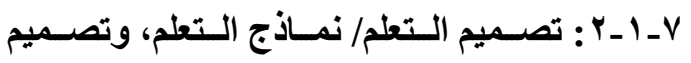

المتغيـرات (الإسـتراتيجية المقترحسة القائمـة على

الــمـج بـين إسـتراتيجية التنظـيم الــذاتي للـتعلم

ومجتمعات الاستقصاء عبر الويب).

نظرًا لأن البحث الحسالي يهدف إلى الكثف عن

أثر إستراتيجية قائمسة على اللدمج بين إستراتيجية

التنظيم الـذاتي للتعلم ومجتمعـات الاستقصساء عبر

الويـب، علـى الحضــور المعرفـي، والاجتمــاعي،

والإنجاز الأكاديمي، والتعامل مع الضغوط الأكاديمية

خلال مقرر نظم إدارة التعلم الإكتروني للدى طلاب

الاراسات العليا في كلية التربيـة؛ لذلك فقد استخدم

الباحسث إســتراتيجية قائمسـة علــى الـــمـج بـين

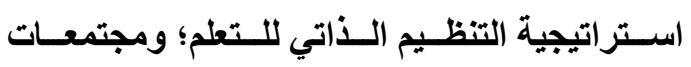

الاستقصاء عبر الويب، وذلك على النحو الموضـح

في الشكل (†): 
الجمعية المصرية لتكنولوجيا التعليم

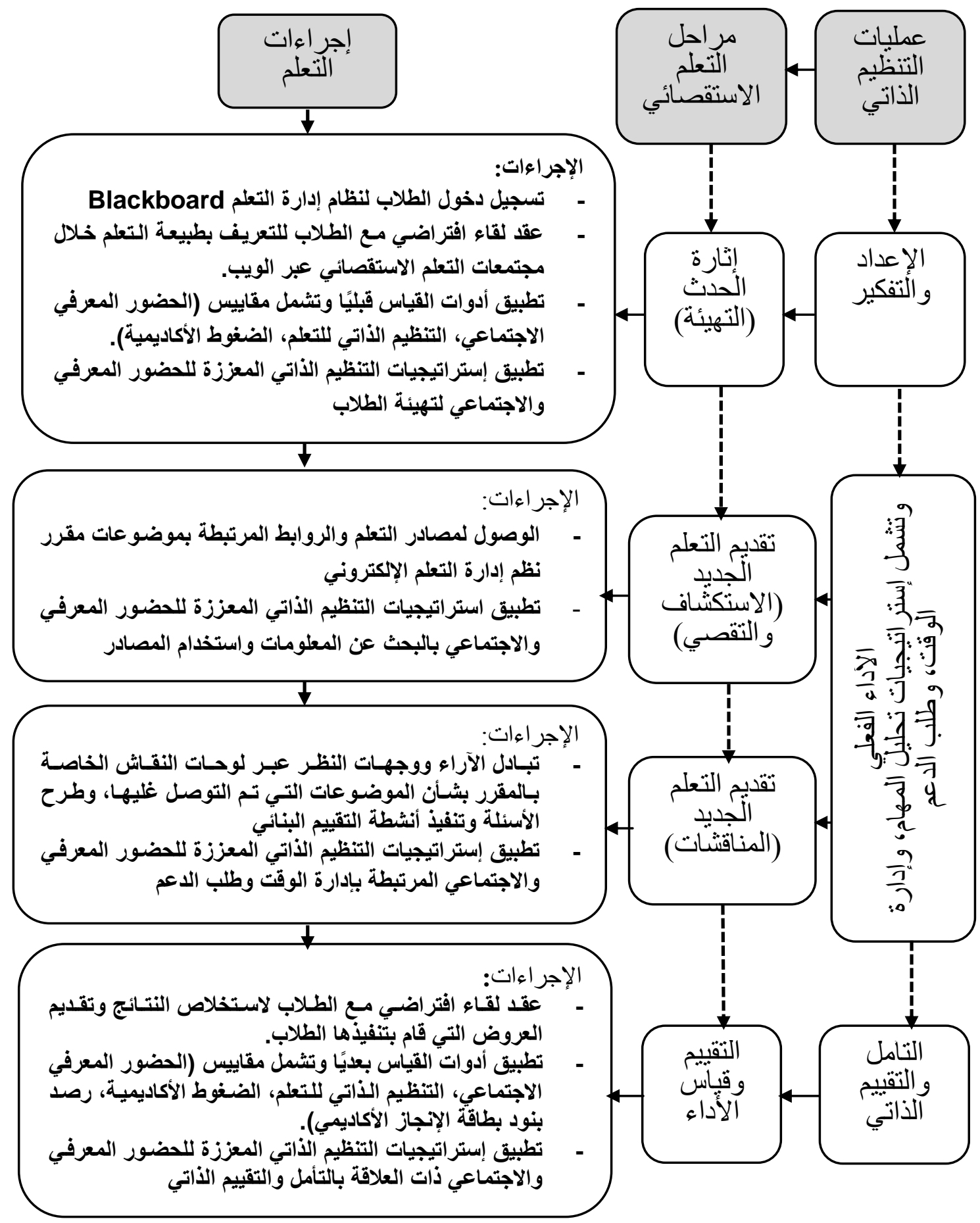

\section{شكل(")}

مخطط توضيحي للاستراتيجية المقترحة القائمة على الامج بين استراتيجيتي التنظيم الذاتي للتعلم ومجتمعات

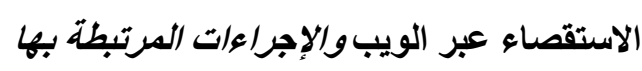


الجمعية المصرية لتكنـولوجيا التنعليم

سواء كان ذلك عن طريث مشـاركة مقالـة، أو

صورة، أو مقطع فيديو، أو رأي، أو رابط، أو

طــرح استفســار، وكــللك التوعيــة بأهميــة

المشاركة والإشارة للمعوقات المحتملة وكيفية

التظلب عليها.

تــوفير روابـط لمــوارد ومصسـادر الـتعلم ذات العلاقة بأهداف التعلم مثل: صفحات الويب، مقــاطع الفيـديو، عناصـر المحتـوى الرقمـي بأثكالهها، وحث المشاركين على الوصول إليها واسـتخلاص إجابــات الاســئلة المطروحــة، وتحديد مدى ارتباطها بأهداف التعلم. - مطالبــة المشــاركين بمشــاهدة مقطـع فيـديو وعرض تقديمي يتضمن تعريف بمجتمع التعلم الاستقصـائي وفلسـفته والنظريـات التـي يقـوم عليها وأنواع الحضور وأدوات بنـاء مجتمعات التعلم الاستقصائي وفوائده في عمليات التعليم والتعطم.

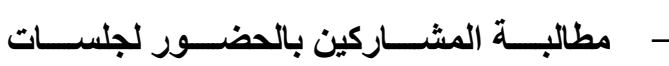
افتراضية ذات علاقة بأهداف التعلم ومحتواه وطبيعـة مجتمــع الـتـعلم ومكونـاتــه، وآليــات العمل، وتعليمات المشاركة والتفاعل. - مطالبـة المشـاركين بالاستجابة على مقـاييس

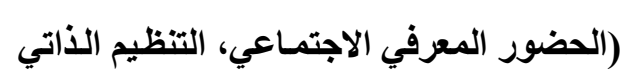
للتعلم، الضغوط الأكاديمية).

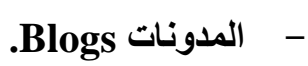
تُعد المدونة بمثنابـة مسـاحة عبر الويب لتشـارك الآراء و المعلومات، والتشارك والتفاعل الإكتروني،

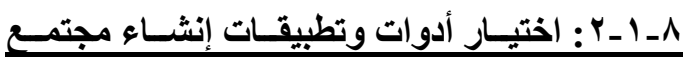
التعلم الاستقصائى عبر الويب:

تــــم تعديــــ مجموعــة مــن الأدوات لتطــــير

مجتمعات التعلم الاستقصائي ضمن Blackboard تمثلث في:

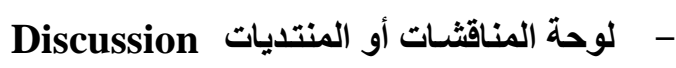
.Board \& Forum عبارة عن مساحة تواصل تتيح للطلاب التفاعل والتثـارك معَّا في الرأي والتعليق وتلقـي التغذيـة

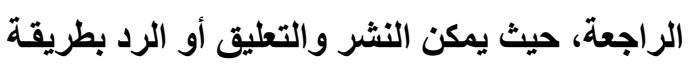

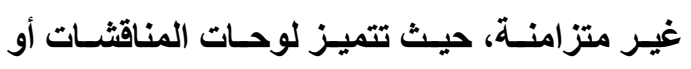

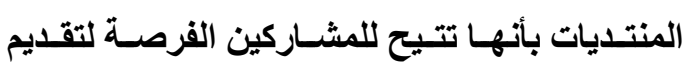
تعليقـات أو ردود مدروســة جيـًا ناتجـة عـن تأمـل وتفكير في التعلم، وتم توظيف لوحات المناقشـات أو

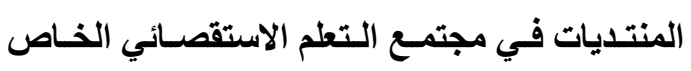
بالبحث الحالي على النحو الآتي: - التعـارف بـين الباحث والمشـاركين وبعضـهم البعض، حيث تـم طلب مقطع فيديو مسن كل مشارك عبارة عن · r ا ث يقدم فيه المشـارك نفسـه للآخـرين موضـحاً تفضـيلاته وخلقياتـه بثـأن موضـوع التعلم وهـو نظـم إدارة التعلم

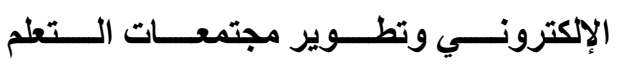
الاستقصائي ومدى رغبته في تعلمسه ود|فعيته نحو الاستفادة منه في عمله كمعلم. - تخصــيص مســــاحة لتشـــــارك اهتمامــــات المشـاركين وتوقعـاتهم بثـأن أهـداف الـتعلم،

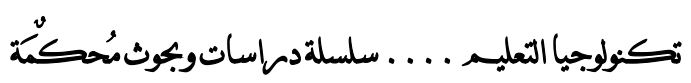


الجمعية المصرية لتكنولوجيا التعليم

المناقثــات مـن حيـث علاقتـهـه وارتباطـهـه بأهداف مجتمع التعلم. - مطالبـة المشــاركين بإبــاء الـرأي بشـأن

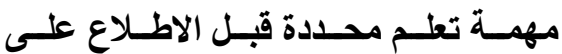
محتـوى الـتـلم الجديـد، ثـم رأيهــم بعـد الاطـلاع على محتـوى الـتعلم الجديـــــــع تبريز ذلك.

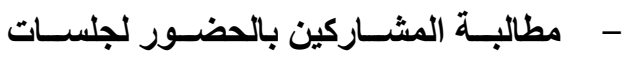
افتراضية أو مشـاهدة جلسـات مسجلة ذات علاقـة بأهــاف التتعلم ومحتـواه وطبيعـة مجتمـع التتطلم ومكوناتـه، وآليـات العمـل، وتعليمات المشاركة، و التفاعل.

- محررات الويب التشاركي/ الويكي مiki. عبسارة عن أداة غير تزامنيـة لتـأليف وتثـارك المحتوى، حيث يمكن للمشـاركين تثـارك المعارف والآراء والمحتوى الرقمي بأثكاله المتنوعة، سواء ضـمن الصـفحة ذاتهـا، أو بإنثـاء صـفحة ويكي جليدة، حيـث تُعد الـويكي مـن الأدوات الفاعلـة في إنثاء مجتمعات التعلم الاستقصائي، كمـا أنها تتميز بسهولة الاستخدام، وتم توظيف الويكي في مجتمع الـتعلم الاستقصــئي الخـاص بالبحـث الحسالي على النحو الاتي: - الني

- - مطالبـة المشــاركين بـأن يقـوم كـل مـنهم بإعــداد مســتخلص وتقريـر فـي حسدود صفحتين بشأن محاور التطلم ودلائل إنجاز كل هدف من أهداف التعلم، على أن يكون
حيث تتيح الفرصة للمتعلمين المشاركين في التفكير العميق والتأمل في التعلم، وتبادل الآراء ووجهات النظر بثــأن التعلم، ويطلـق عليهـا أيضَــا سـجلات الويب حيث تسمح بنشر الآراء، قد يكون مسؤولًا عنها فرد أو مجموعة، وتسمح بتضمين ارتباطات تثعبية لصفحات ومواقع ويب وكذلك صور ومقاطع فيديو ومحتوى نصي ومقاطع صوتية، وتم توظيف المدونات في مجتمع التعلم الاستقصـئي في البحث الحالي من خلال المهام الاستقصائية الآتية: - م طرح أسئلة استقصائية استرشاديه تسـاعد المشــاركين على استنتتاج مجـالات التتطلم اللازمة لتحقيق الأهداف التعليمية.

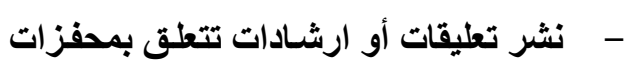
المشاركة في التعليق والحوار مثل الإشارة لمصادر تعليميـة خارجيـة أو روابط لقوائم أو مراجع أو صور أو مقاطع فيديو.

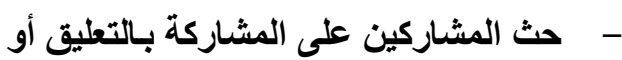
كتابـة مقـالات مصـغرة تسـهم في تحقيـق أهداف أو هدف محدد من أهداف مجتمع

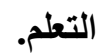
- ـث المشــاركين للاطـلاع على مسـاهمات الآخرين والتطليق عليها وتقيم الملاحظات البنـــاءة بثــأنها وتبريسـر الملاحظــات أو التعليقات المقدمة. - - مطالبة المشـاركين بـالتعليق على محتوى (مرئي، نصي، سمعي) شـاهدوه في لوحة 
الجمعية المصرية لتكنولوجيا التعليم

$$
\text { - - أدوات مساعدة. }
$$

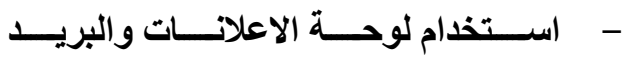

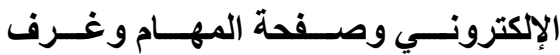

الدردشــة لحـث المشـاركين على التفاعل

والمشــاركة في مســاحات التثــارك مثـل

الويكي والمدونات ولوحات المناقشات.

MCQs -

المنشورة عبر لوحة المناقشات والتكليفات

لتوجيـه مســار المناقثــات نحـو أهـداف

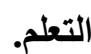

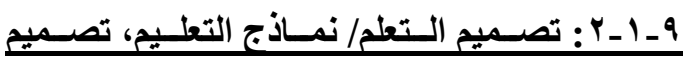

المتغيرات، ونظريات التعلم.

- -

طالب بمشـاركة تعليق تمهيدي تعريفي خـاص بـه)، إنثـاء ويكي (يطلب من كل طالب إنثـاء صفحة ويكي تعريفية تتضمن بياناته واهتماماتـه وتوقعاتسه وخبراتـه وتجاربـه الثخصـية بثــأن

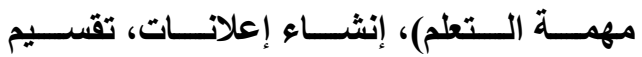
المجموعـات، إنثـاء عروض تقديمـة تثـاركية، حيث يتم تخصيص شريحة لكل طالب يعرض اهتماماته وتوقعاته، قيام كل طالب بإعداد مقطع فيديو تعريفي له، الإجابة عن اختبار قصير).

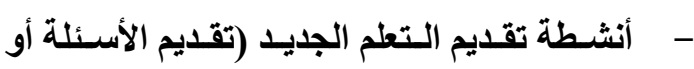
محفزات الاستقصاء، وضع روابط في المنتدى

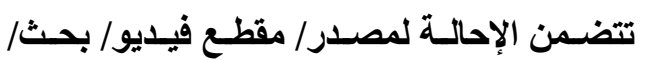
صفحة ويب، ويطلب من المتعلم كتابـة تعليق
ذلك على الويكي الفردي للمشـارك، ويتم مشاركتها في الويكي الجماعي للمقرر. - مطالبـة المشـاركين بإعداد خريطـة ذهنيـة لمحاور التعلم وجوانب الأهداف التعليمية، يوضـح مسن خلالهـا أوجـه اسـتفادته مـن إنجاز التعلم الخاص بهذف معين. مطالبة المشـاركين بإعداد عرض تقديمي يتضــمن مسـتخلص لأبـرز النقــاط التـي استفاد منها المشـارك خلال إنجـازه للمهام التعليميـة، وكــلك التحــيات و الصـعوبات التي واجهته، وكيف يمكن الاستفادة من

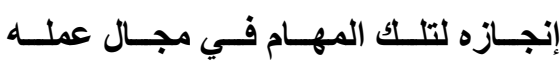

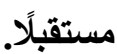
مطالبـة المشـاركين بإعداد قائمـة تتضـمن (0: · • 1 ) روابط لمصـادر تعلم ذات علاقة

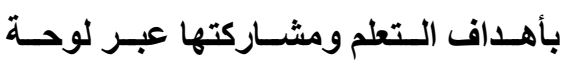
المناقشات العامة في المقرر. - - مطالبة المشـاركين بإنشـاء مقطع فيديو أو عرض تقديمي • 11 أث بعنـوان تجربتـي أثناء مجتمع التعلم، يوضح من خلاله كيف استفاد من المهام الاستقصـائية والأنثطة التــي تــم تنفيــها، ويـــكر أمثلــة لـبعض إســتراتيجيات تعزيـز الحضــور المعرفـي والاجتمـاعي في بيئسة التعلم، ويشـير إلـى مصدر تعلم تم الرجوع إليه لإنجاز المهام

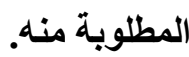

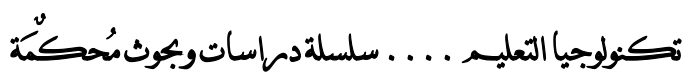


الجمعية المصرية لتكنولوجيا التهليم

وسائل التواصل المتزامنة مثل الفصول الافتراضية وغرف الاردشة، ووسـائل التواصل غير المتزامنـة

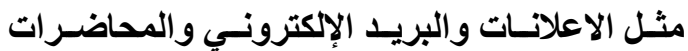

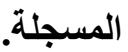

تصـــيم طريقـــة تســـيل المتعلمــين و إدارتهـــ، وتجميعهم، وتوفير نظام الدعم لهر.

يتطلب دخول المشـاركين تسجيل اسـم مستخدم وكلمـــة ســـر، ونظـــرًا لأن نظـــام إدارة الــتعلم Blackboard هو النظام المستخدم، فإن كل طالب له حساب للاخول على نظام إدارة التعلم، والوصول للصفحة الرئيسية للمقرر ومكونـات مجتمـع التعلم الاستقصائي والمحتوى والصفحات الخاصـة بـه في أي توقيت ومـن أي مكـان، كمـا يتوفر في الصفحة الرئيسية للمقرر مقاطع فيديو وكذلكك أدلة إرشـادية ووسائل لتقديم الدعم سواء وسائل اتصال مباشر أو اتصـال عبـر الواتســاب، كمـــــــوفر مقطـع فيـديو تعريفي بمجتمع التعلم الاستقصائي عبر الويب. ب- مرحلة الانتاج والانشاء.

1-ب- إنتاج مكونات مجتمع التعلم الاستقصائى عبر الويب. قام الباحث بإعادة تهيئة صفحة المقرر الاراسي والصفحات العامة لأدوات مجتمع التعلم الاستقصائي (Discussion board \& Forum, Blogs, ضikis) تصــميم روابطهـا ضـمن قائمــة المقـرر، وتجهيـز

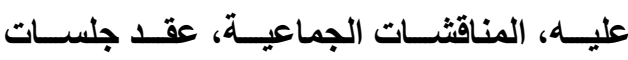
افتر اضـية) مـع مراعـاة التــكير دائمًا بأهميـة التثـارك الاجتمـاعي مثل: الـويكي، المـدونات، المناقشات مع توفير إرشادات الاتاحة والوصول

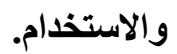
- - أنثــطة تعزيـز العضـور الاجتمـاعي وتثـــل (اســـذام المعلــم للإعلانــات، رســائل البريــــ، النشر في لوحة المناقشـات والمدونات ورسـائل الاردشة، استخدام مواقع الويكي والمدونات).

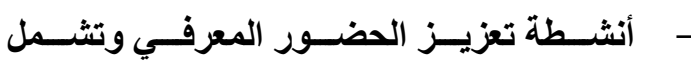
(مشـاركة الأهداف و التوقعـات والتعليمـات، مـع بيـان مستوى المشــاركة وتوقيتاتهـا و أدواتهـا، وأنماطها، يقوم المعلم بـالتعريف بنفسـه ويطلب مـن المتطمسين فعل نفس الثــيء، عقد جلسـة افتراضـية تمهيديـة، تحديــ معسيير المناقثــات وقو اعد السـلوك المرتبطـة بهـا، طرح الاسـئلة المفتوحـة ومحفزات النقـاش، تـدعيم مناقشــات المتعلمـين بـالمراجع العلميـة، تقـــيم التغذيـة

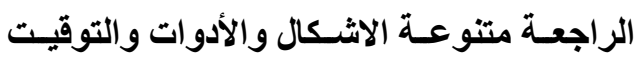
المناســـب، جدولـــة الجلســـــات الافتراضــــــة

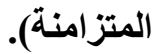

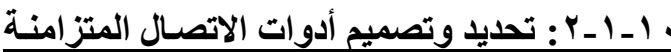
وغير المتزامنة داخل وخارج مجتمع التعلم.

نظرًا لأن نظام إدارة التعلم Blackboard هو النظـام الذي تـم الاعتمـاد عليهه في تطوير مجتمع التعلم الاستقصـائي، لـذا تم مراعـاة الاستفادة مـن 
الجمعية المصرية لتكنولوجيا التهليم

التحقق مـن إمكانيـة رفـع ملفـات إلـى أدوات انشـاء

مساحات مجتمع التعلم الاستقصائي، ليصبح مجتمع التعلم الاستقصائي جاهز للاستخدام. •ـ مرحلة الاستخدام.

تضــمنت هـذه المرحلـة الإجــراعات المتعلقــة بالتجربـة الاسـنطلاعية وكـذلك التجربـة الأسـاسـية للبحث، وتتفيـذ إجـراءات البحث، وتطوير الطـلاب للصـفحات العامـة والفرديـة، وكـذلك تطبيـث أدوات القبـاس، ورصــ الـدرجات وكـللك مؤشسرات رصــ الحضـور المعرفي والاجتمـاعي، والتنظيم الـذاتي للتعلم، والضغوط الأكاديمية. ثالثا: تصسميـم أدوات البمث. يـهـدف البحـث الحـالي إلـى الكثـف عـن أثـر اسـتراتيجية قائمسة على الـدمج بـين إسـتراتيجيتي التنظيم الذاتي للتعلم ومجتمعسات الاستقصساء عبر الويسب، علــى الحضـور المعرفـي، والاجتمــاعي، والإنجاز الأكاديمي، والتعامل مع الضغوط الأكاديمية خلال مقرر نظم إدارة التعلم الإكتروني لدى طلاب الاراسـات العليا في كلية التربية، لذا تضـنت أدوات القياس في البحث الحالي (مقياس الحضور المعرفي الاجتمـاعي، مقيـاس التظظيم الذاتي للتعلم، مقيـاس الضـغوط الأكاديميـة)، فيمـا يلـي الخطوات التي تـم اتباعها لإعداد هذه الأدوات: 1 - مقيــاس الحضــور (المعرفـي، الاجتمــاعي، والتعليمي) لاى طلاب الدراسات العليا.
العـروض التقديميـة والجلسـات المسـجلة وكـذلك صــفحة الجلســات الافتراضـية للمقـرر، وتجهيـز المحتوى النصسي الذي سـيتم تضـمينه، مـع تجهيز قوالب الأثـطة والمهـام الاستقصـائية التـي سـيتم استخد/مها.

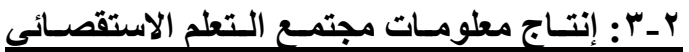
وشكل المكونات.

تـم إنشــاء قائمــة المقـرر الرئيسـية والقائمسة الفرعيــة الخاصــة بمجتمــع الـتـعلم الاستقصــائي، وروابـط الأدوات المســخدمة لبنـاء مجتمـع الـتعلم الاستقصـــائهي، والأدوات المســــاعدة مثـــل أدوات

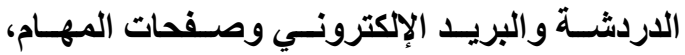
والجلسات الافتراضية والأدلة الارشادية اللازمة. ع - مرحلة التقويم. تـــم التحقــق مــن صــحة القــوائم والــروابط الموجودة، كما تم تطبيق مجتمع التعلم الاستقصـائي الذي تم إنشـاءه على مجموعـة من طلاب التدريب الميداني وعددهم (1 1) حيث تـم دعوتهم كضيوف في نظـام إدارة الـتعلم الإكترونسي Blackboard وبالتــالي الــدخول لأدوات إنشــاء مجتمــع الـتـعلم الاستقصـائي، ومعرفـة أراءهـم مـن حيـث سـهولة الوصول ووضوح الأدوات والقوائم، وكذلك وضوح نمــاذج تصــميم الأنشــة والمهــام الاستقصــائية، وسهولة تحميل وتثـغيل عناصر الوسـائط المتعددة المضـنة والوصول للجلسـات الافتر اضية، وارسـال بريـــ الكترونـي واسـتخدام غـرف الاردشــة، مـع

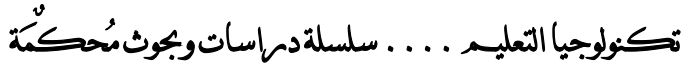


الجمعية المصرية لتكنولوجيا التعليم

مؤشــر لقيـاس الحضـور المعرفـي، الاجتمــاعي،

التدريسـي في مجتمعسات التتعلم الاستقصسائي عبر

الويب.

ع ـ ا : ضبط المقياس مرورًا بالخطوات الآتية: ا ــ ـ ا : صــدق محتـوى المقيـاس: يشـير صـدق المقيـاس إلى صـة الاسـتلالات التـي يـتم التوصـل إليها من درجات المقياس من حيث فائدتها ومعنـاهـا

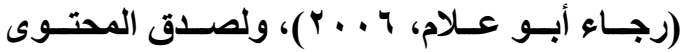
بُعـدان: الأول هـو الصـــ الظـاهري، الـذي يـرتبط بمـى وضـوح فقرات المقيـاس ( سـهولة القراعة، الوضـوح، ارتبـاط الفقـرات باللهـدف، الخلـو مـن الأخطـاء)، أمــا البعـد الثـاني فيتعلق بمـدى تمثيـل الفقرات للمجـال المُحدد من وجهة نظر المحكمين، وللتحقق مسن صـدق المحتوى تـم عرض المقيـاس على مجموعـة مـن المتخصصسين فـي تكنولوجيـا

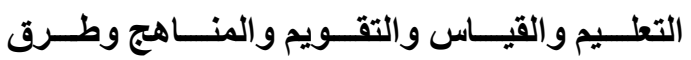
التـــريس، لإبـــاء الـرأي فـي خلـو المقيـاس مـن الأخطــاء العلميــة والطباعيــة واللغويــة، وارتبــاط فقزات المقياس بالأبعاد الرئيسية التي تشـملها، وتم إجـراء التعـديلات فـي الصـياغة والـدمج والحـذف لبعض الفقرات في ضوء اتفاق المحكمين.

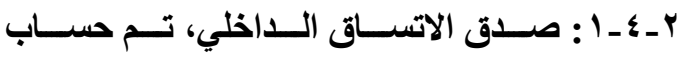
معاملات تمبيز فقرات المقياس: بعد تطبيق المقياس على عينــة اسـتطلاعية (1 11 ) طالـب مــن طـلاب التـدريب الميداني، تـم حسـاب الصـدق الداخلي عن طريق حسـاب معساملات الارتباط بين درجة الفقرة
تم إعداد المقياس لأنواع الحضور الثُلاث، لكن عند التطبيـق و الرصـــــــم تفعيـل محـوري الحضــور المعرفى والاجتماعى فقط؛ وفق هدف البحث. 1ـ ا : تحديـ الهدف مـن المقيـاس: يـهدف المقيـاس إلــى التعـرف علــى مـــى إســهام مجتمــع الـتـعلم الاستقصائي عبر الويب في تطوير الحضور بصوره الثثلاث (معرفي، اجتماعي، تعليمي أو تلريسي) للى طلاب الار اسـات العليا. ץـ ا : الصـورة الأوليـة للمقيـاس: تـم الاطـلاع على بعـض الدراســات السـابقة ذات العلاقـة بمجتمعـات التعلم الاستقصسائي والحضور بأنواعه Garriso) et al., 2001; Kumar \& Ritzhaupt, 2014; Rogers \& Van Haneghan, 2016; ‘Baldwin \& Ching, 2019; Fiock, 2020)

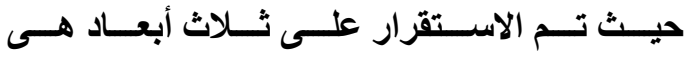

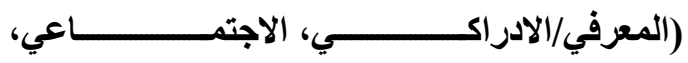
التعليمي/التدريسي)، حيث تضمن كل بعد مجموعة من البنود المستخدمة كدلالة على مستوى توفره. rـ ا : صياغة تعليمات المقياس وتقدير الاستجابات: تــم صـياغة تعليمــات المقيــاس، حيــث اشـتملت التعليمـات المتعلقة بالهـف مـن المقيـاس، وتعريف المصـطحات الرئيسـية، وكذلك طريقة الاسـتجابة، ونظــام تقـــير الاسـتجابات، وتـم اسـتخدام تـــريج Likert الثلاثي (موافق وتقدر كميًا بثثلاث درجـات، لا أعرف وتقدر كميًا بـدرجتين، غير موافق وتقدر

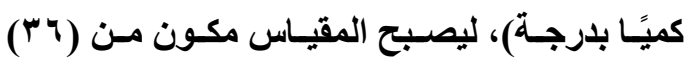


الجمعية المصرية لتكنولوجيا التهليم

لارتباط الفقرة بالبعد الذي تتتمي إليه:

والدرجة الكلية للبعد الذي تتتمـي إليه، حيث يتضح

من الجدول (ץ) أن قيم معاملاث الارتباط جاءت دالة

جدول (r)

نتأتج حساب معاملات تمبيز فقرات المقياس (الصدق الد/خلي)

\begin{tabular}{|c|c|c|c|c|c|}
\hline \multicolumn{2}{|c|}{ الحضور التدريسي } & \multicolumn{2}{|c|}{ الحضور الاجتماعي } & \multicolumn{2}{|c|}{ الحضور المعرفي } \\
\hline معامل الارتباط & الفقرة & معامل الارتباط & الفقرة & معامل الارتباط & الفقرة \\
\hline$* * . \Delta \mu r$ & YI & **. & Ir & $* . . \leqslant 7 V$ & 1 \\
\hline$* * . .711$ & rr & $* * . .7 \leq 9$ & ir & $* * .701$ & $r$ \\
\hline$* *, . \vee Y \leq$ & $r r$ & $* . . \leqslant \wedge q$ & $1 \leq$ & $* *, v, 1$ & $r$ \\
\hline$* * .771$ & $r \varepsilon$ & $* * .07 \varepsilon$ & 10 & $* * . \Delta \mu \Lambda$ & $\varepsilon$ \\
\hline$* * . . \Delta V r$ & ro & $* * . . \diamond \sim q$ & 17 & $* . .0 Y r$ & 0 \\
\hline$* * . . \Delta \wedge r$ & Y & $* . . \leqslant \wedge \wedge$ & IV & $* * . . V \mid \varepsilon$ & 7 \\
\hline$* *, .0, \mu$ & $r V$ & $* * . .7 \vee \leq$ & 11 & $* * . .7 \leq 1$ & V \\
\hline$* *, . \vee 71$ & $r \wedge$ & $* * . .711$ & 19 & $* * .091$ & $\Lambda$ \\
\hline$* * . . \diamond \wedge V$ & rq & $* *$ *.VYr & $r$. & $* * . \vee 19$ & 9 \\
\hline$* * .019$ & $r$ & & & $* * .700$ & 1. \\
\hline$* . \varepsilon 91$ & r & & & $* * . .0 \vee 9$ & 11 \\
\hline$* * . .07 V$ & rr & & & & \\
\hline$* * . .711$ & rr & & & & \\
\hline$* * . .7 \leq \mu$ & q & & & & \\
\hline
\end{tabular}

rـ ـ ـ ا : حساب ثبات المقياس، يثير مفهوم الثبات إلى اتساق نتائج المقياس، أي إمكاتية الحصول على نفس النتائج إذا مـا أُعيد التطبيق (رجـاء أبو علام، צ . . . )، ولحساب ثبات المقياس تم حساب الاتساق الاخلي واستخدام معامل الفـا كرونبـاخ، حيث بلغت
كمـا تـم حسـاب معساملات الارتبـاط بـين أبعـاد المقيـاس الـثلاث والدرجـة الكليـة للمقيـاس، حيـث

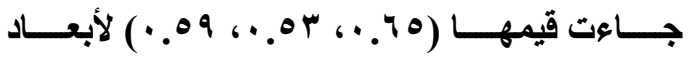
الحضـور المعرفي، والاجتمـاعي، التدريسي، على التربيب، وبالتالي فإن المقياس يتسم بالصدق. 
الجمعية المصرية التكنولوجيا التعليم

بنية وتنظيم مجتمـع الاستقصساء عبر الويب، هيكلة وتنظيم وتحليل المهام والأنشطة الاستقصائية عبر الويب، إدارة وقت التعلم المتزامن وغير المتزامن، طلب الـدعم والوصـول للمعلومـات، التأمسل والتقيـيم الأتي، وفي ضوء تلك الأبعاد تم صياغة المؤشرات الدالة على كل بعد منها، ليصبح المقياس مكون من ست أبعاد ثُقاس باستخلام (0 0) مؤشرًا.

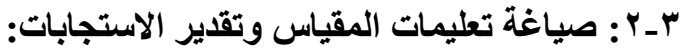
تــم صـياغة تعليمــات المقيــاس، حيــث اشــتملت التعليمـات المتعلقة بالهـدف مـن المقيساس، وتعريف المصطحات الرئيسية، وكـلكك طريقـة الاستجابة، ونظـام تقــير الاسـتجابات، وتــم اســخدام تـدريج Likert الثُلاثي (موافق وثُقدر كميًا بثثلاث درجـات ويتدرج حتى غير موافق وتُقدر كميًا بدرجة واحدة

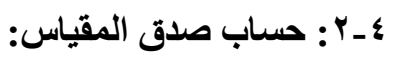

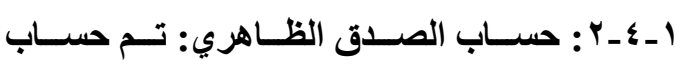
الصــلق مسن خـلال عـرض المقيساس فـي صـورتها الأوليــة علــى مجموعـة مـن المتخصصـين فـي تكنولوجيــا التعلـيم والقيــاس والتقــويم والمنــاهج وطرق الترريس، لإبداء الرأي في خلو المقياس من

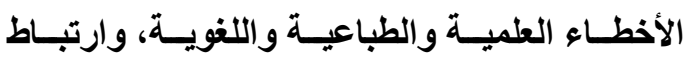
فقرات المقياس بالأبعاد الرئيسية التي تثــلها، وتم إجـراء التعـديلات فـي الصـياغة والـــــ والحــف لبعض الفقرات في ضوء اتفاق المحكمين.

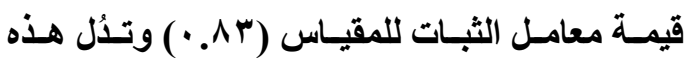
القيمة على معامل ثبات مقبول للمقياس. ـ ـ ـ ا ا : الصــورة النهائيـة للمقيـاس، بعـد إجـراء التعديلات اللازمسة في ضسوء نتـائج حسـاب الصداق والثبـات تــم التوصـل للصــورة النهائيـة للمقيـاس الحضور بأنواعه في مجتمع التعلم الاستقصائي عبر الويب للدى طلاب الار اسـات العليـا (ملحق ب)، ثم Microsoft برمجة المقيـاس باستخدام برنـامج وتهيئة الر ابط الخـاص بـه لتضمينه ضمن forum مجتمع التعلم الاستقصائي. r- مقيـاس التظظيم الـذاتي للتعلم في مجتمعسات الاستقصاء عبر الويب.

I_Y : تحديد الهدف من المقياس: يهدف المقياس إلسى تحديـل مسـتوى تـوفر مهـارات التنظيم الـذاتي للتعلم في مجتمعـات الاستقصـاء عبر الويـب لـى

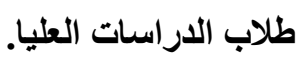
Y-Y : الصـورة الأوليـة للمقيـاس: تـم الاطلاع على بعض الدراسـات التي اهتمت بتطوير أدوات لقياس (Pintrich et al., 2000; التعلم اليُنظم ذاتيًَا Zimmerman \& Moylan, 2009; Dabbagh \& Kitsantas, 2013; Yen et al., 2017; Araka et al., 2020; Carter et al., 2020; Zheng et al., 2020) أستقر الرأي على تحديد أبعاد مقياس التظظيم الذاتي

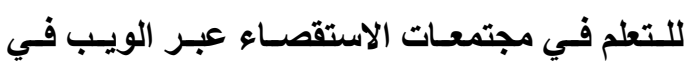
الأبعـاد الآتيـة: تخطيط الأهـداف والتوقعـات، إدراك 
الجمعية المصرية لتكنولوجيا التعليم

يتضـح مـن الجـدول (ع ) أن قيم معساملات الارتبـاط

Y - צ - Y : حساب صدق الاتسـاق الداخلي: تم تطبيق جاعت دالة لارتباط الفقرة بالبعد الذي تنتـي إليه، المقيساس على عينـة استطلاعية (1 1) طالب مـن كما تم حساب معاملات الارتباط بين أبعاد المقياس طلاب التدريب الميداني، ثم حسـاب الصدق الداخلي الست والارجة الكلية للمقياس، كما هو موضح في

عن طريـق حسـاب معساملات الارتبـاط بـين درجـة

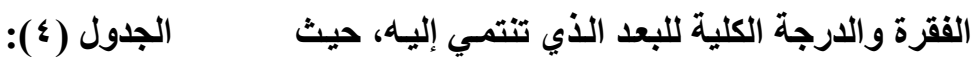

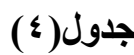

تتائج حساب معاملات الارتباط بين أبعاد مقياس التنظيم الن/تي للتعلم في مجتمعات الاستقصاء عبر الويب واللارجة الكلية للمقياس

\begin{tabular}{|c|c|c|}
\hline 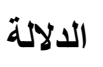 & 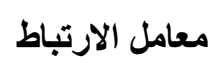 & البعد ال البع \\
\hline 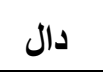 & $* * . .0 Y 1$ & تخطيط الأهداف والتوقعات \\
\hline 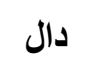 & $* \cdot . \leqslant r q$ & إدراك بنية وتنظيم مجتمع الاستقصاء عبر الويب \\
\hline 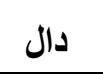 & $* * \cdot .0 \leq 9$ & تنظيم وتحليل المهام والأنثطة الاستقصائية عبر الويب \\
\hline 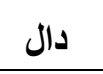 & $* . . \varepsilon \vee r$ & إدارة وقت التعلم \\
\hline 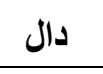 & $* . . \leqslant \wedge 9$ & طلب الدعم والوصول للمصادر \\
\hline 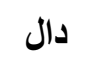 & $* * . .07 r$ & التأمل والتقييم الذاتي \\
\hline
\end{tabular}

r- مقيـاس الضـفوط الأكاديميـة فـي مجتمعـات الاستقصاء عبر الويب.

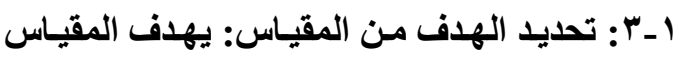
إلسى تحديــ طبيعـة اسـتجابات، ومظــاهر الســوك، وإســتراتيجيات التعامــل، المرتبطـــة بالضـــوط الأكاديمية التي يثعر بها طالب الدراسـات العليا في مجتمع التعلم القائم على الاستقصاء عبر الويب. ץ-ץ" الصورة الأولية للمقياس: تــم إعــاد الصــورة الأوليـة للمقيـاس مـن خـلال إجرائيين هما: - إن هـr : حساب ثبات المقياس، لحساب ثبات المقياس تم حسـاب الاتســاق الــاخلي واسـتخدام معامـل الفـا كرونبـاخ، حيث بلغت قيمـة معامـل الثبات للمقيساس

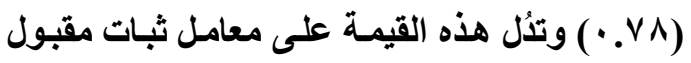
لمقياس. T-Y : الصــورة النهائيسـة للمقيــاس، بعـــ إجـراء التعديلات اللازمـة في ضسوء نتائج حسـاب الصدق والثبـات تــم التوصـل للصــورة النهائيـة للمقيــاس (ملحق \& )، ثم برمجـة المقيساس باستخدام برنـامج Microsoft forum لتضمينه ضمن مجتمع التعلم الاستقصائي.

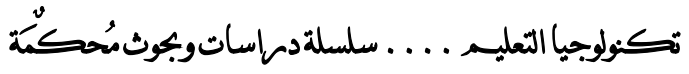


الجمعية المصرية لتكنولوجيا التعليم

يدرسـون مقـررات تربويـة لضــــان تثــابه طبيعـة المقررات كي لا تكون متغير دخيل يؤثر في أراءهم-

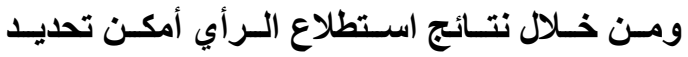
مجموعة من الأبعاد ومجموعة من العوامل المسبية أو مظاهر السلوك المرتبطة بالضغوط الأكاديمية في بيئات التعلم عبر الويب، كما هو موضح في الجدول
الأجر اء الأول: عمل دراسة استطلاعية لطلاب كلية التربية - حيث مر عام على تعاملهم مع بيئات التعلم عبـر الإنترنــت ــــــــ التعـرف عـى مسـببات ومظاهر الضـغوط الأكاديمية التي شعروا بها خلال تفاعلهم مع بيئات التعلم عبر الإنترنت، وتم تطبيق

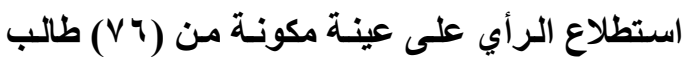
مـن طـلاب كليتـي التربيـة والعلـوم والآداب والـذين

جدول (0)

نتائج استطلاعات رأي الطلاب في مظاهر الضغوط الأكاديمية المرتبطة بالتعلم في بيئات التعلم عبر الويب

\begin{tabular}{|c|c|c|c|}
\hline$\%$ & كو & مؤشرات/ مظاهر السلوك المرتبطة بالضغوط الأكاديمية في بيئة التعلم عبر الويب & م \\
\hline$\% \wedge r . q$ & r & أشعر بالخوف من الفشل في أداء الاختبارات الإكترونية & 1 \\
\hline$\% 9 r .\{$ & $v_{1}$ & كثرة التكليفات والأنشطة التي يكلفنا بها أستاذ المقرر في التعلم عبر الإنترنت & r \\
\hline$\% \curlyvee \wedge . \varepsilon$ & or & أشعر بالضيق لكثرة الوقت اللازم للتعلم عبر الإنترنت & r \\
\hline$\% 9 \cdot . \wedge$ & 79 & أثعر بالقلق من الأعطال التقنية التي تحدث أثناء التعلم عبر الإتترنت & $\varepsilon$ \\
\hline$\%$ \%.1 & 01 & لا تتوفر لاي المهارات الكافية لاستخدام أدوات وتطبيقات التعلم عبر الإنترنت & • \\
\hline$\%$ & $\leqslant 9$ & كثرة المصادر والمراجع التي تتاح لي عبر الإتترنت يشعرني بالتثتت وعدم التركيز & 7 \\
\hline$\%$ & $\leq \uparrow$ & يزعجني عدم تقدير زملائي للتعليقات ووجهات النظر التي أطرحها في أدوات النقاش & 9 \\
\hline$\%$ & $\leqslant V$ & أثشع بالتوتز عندما أُكلف بمهام أو أنثطة جماعية أو العمل في مجموعات عبر الإنترنت & 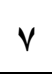 \\
\hline$\% 79 . \vee$ & or & أشعر أن التعلم عبر الإنترنت لا يساعدني على فهم بعض الموضوعات وخاصـة المهارات & $\Lambda$ \\
\hline$\% \wedge 9.0$ & 71 & أرى أن شعوري بالارتياح والأمسان في بيئـات التعلم التقليديـة أعلى منـه في بيئات التعلم & 9 \\
\hline$\% \wedge \varepsilon . \curlyvee$ & $7 \varepsilon$ & عدم الاستمر بصعوبة أداء المهام عبر الإنترنت مما يزيد المجهود الذي أبذله لمقاومة الرغبة في & 1. \\
\hline
\end{tabular}

(Bedewy \& الأكاديمية في بيئات التعلم عامـة الإجراء الثانى: الاطلاع على بعض الاراسـات التي

Gabriel, 2015; Ramli et al., 2018; اهتمــت بتطــوير أدوات لقيـاس مسـتوى الضــنوط 
الجمعية المصرية لتكنـولوجيا التنعليم

التعامـل مــع الضــوط الأكاديميـة المصــاحبة

$$
\text { للتعلم عبر الويب. }
$$

rـr بـ صياغة تعليمات المقياس وتقدير الاستجابات: تــم صـياغة تعليمــات المقيــاس، حيــث اشـتملت التعليمـات المتعلقة باللهدف من المقيـاس، وتعريـف المصسطحات الرئيسية، وكذلك طريقـة الاسـتجابة، ونظـام تقــير الاســتجابات، وتـم اسـتخدام تـــريج Likert الثلاثي (مرتفعة، متوسطة، منخفضة). ع ז'Y: حساب صدق المقياس:

ا ــــ" حســاب الصــدق الظــاهري: تــم حســاب الصــلق مـن خـلال عـرض المقيـاس في صـورته الأوليـة علــى مجموعـة مـن المتخصصسين فـي تكنولوجيــا التعلـيم والقيــاس والتقـويم والمنــاهج وطرق التدريس، لإبداء الرأي في خلو المقيـاس من الأخطــاء العلميـة والطباعيـة و اللغويــة، وارتبــاط فقرات المقيـاس بالأقسـام والأبعـاد التي تتتمـي لها، وتم إجراء التعديلات في الصياغة والدمج والحذف لبعض الفقرات في ضوء اتفاق المحكمين.

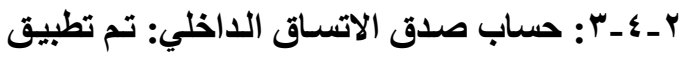
المقيـاس على عينـة اسـتطلاعية (1 1) طالـب مسن طلاب التدريب الميداني، ثم حسـاب الصدق الداخلي عن طريـق حسـاب معساملات الارتبـاط بـين درجـة الفقرة والدرجـة الكليـة للقسم أو البعد الذي تنتمسي إليه، حيث يتضـح من الجدول (") أن قيم معاملات الارتباط جـاعت دالـة لارتباط الفقرة بالقسم أو البعد
Reddy et al., 2018) (Yikealo et al., 2018; الإنترنـت خاصـة Dolfen et al., 2019; Macintyre et al., 2020; Joseph et al., 2020; Friskawati, (2021، ومسن خلالهــا أسـتقر الـرأي على تقسيم المقياس إلى ثلاثة أقسام على النحو الآتي:

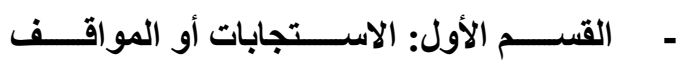
المصـاحبة للشـعور بالضـغوط الأكاديميـة في بيئسات التتعلم عبـر الويـب، حيـث تـم صسياغة مجموعة من العبار ات والاستجابات المرتبطة بها. - القسـم الثـــي: المؤثـرات الدالـة أو مظــاهر الضــوط الأكاديميـة المصـاحبة للـتعلم عبـر الويب، ويتضمن خمسـة ابعـاد هى: خصـائص وطبيعـة بيئـات التعلم عبر الويـب، المناقثـات والتفـاعلات التعليميـة والاجتماعيـة في بيئـات التعلم عبر الويب، التواصل مـع أستاذ المقرر والأقران، طبيعـة أنشـطة التقيـيم فـي بيئـات التعلم عبر الويـب، مستوى الدعم والمسـاندة في بيئـات التتعلم عبـر الويـب، ولكل بعد تـم صـياغة مجموعـة مسن المؤشـرات أو مظــاهر الضغوط المرتبطة به. - القســم الثالــث: إســتراتيجيات التعامـل مــع الضـفوط الأكاديميـة المصـاحبة للـتعلم عبـر الويب، وتضمن قائمة بالإستر اتيجيات المتوقع أن يســتخدمها طالــب الدراســات العليــا فـي

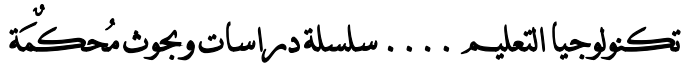


الجمعية المصرية لتكنولوجيا التهرليم

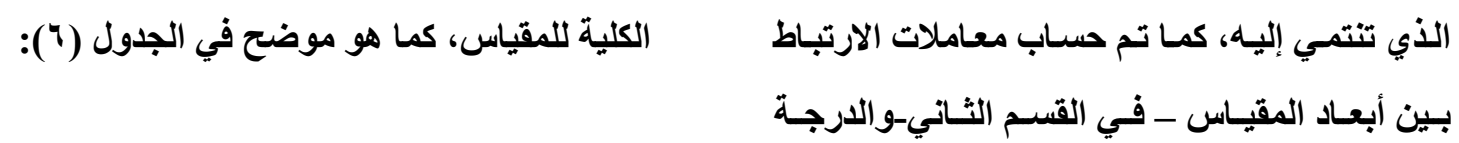

جدول(7)

نتائج حساب معاملات الارتباط بين أبعاد الضنوط الأكاديمية المصاحبة للتعلم في مجتمعات الاستقصاء عبر الويب والدرجة الكلية للقسم الذي تنتهي إلبه (القسم الثاني من المقياس).

\begin{tabular}{|c|c|c|}
\hline 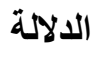 & معامل الارتباط & 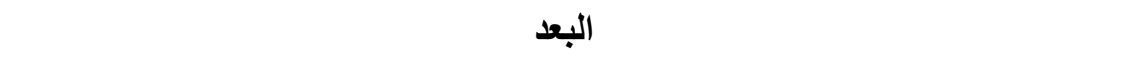 \\
\hline 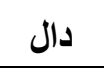 & $* * \cdot .0 r r$ & البعد الأول: خصائص وطبيعة بيئات التعلم عبر الويب \\
\hline 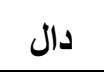 & $* * . .711$ & البعد الثاني: المناقشات والتفاعلات التعليمية والاجتماعية في بيئات التعلم عبر الويب \\
\hline دال & $* . . \leqslant \wedge 9$ & البعد الثالث: التواصل مع أستاذ المقرر والأقران \\
\hline دال & $* * . . \Delta r_{1}$ & البعد الرابع: طبيعة أنشطة التقييم في بيئات التعلم عبر الويب \\
\hline 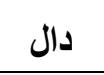 & $* \cdot . \leqslant V_{1}$ & البعد الخامس: مستوى الدعم والمساندة في بيئات التعلم عبر الويب \\
\hline
\end{tabular}

والنهائيسة، والتكليفــات، والو اجبـات، وفـي ضـو

الهـف من البحث الحالي، تم تصميم بطاقة لرصد

مؤشرات الإنجاز الأكـاديمي لطلاب الدراسـات العليا

في مجتمـع التعلم الاستقصـائي عبر الويب مروراً

$$
\text { بالخطوات الآتية: }
$$

1 ـ : : تحديد الهدف من البطاقة: تهدف البطاقة إلى

رصـــ مؤثـرات الإنجــاز الأكساديمي (الاختبــارات

الفصلية، المهام و التكليفات والأنثطة الاستقصـائية،

الاختبار النهائي للمقرر) لطلاب الاراسات العليا في

$$
\text { مجتمع التعلم الاستقصائي عبر الويب. }
$$

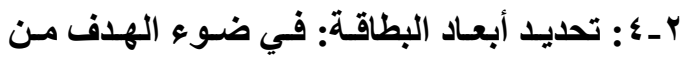

$$
\text { البطاقة تم تحديد أبعادها على النحو الاتي: }
$$

- - البعـد الأول: نتــائج الطـلاب فـي الاختبـار

$$
\text { الفصلي والنهائي. }
$$

هـr : حساب ثبات المقياس، لحساب ثبات المقياس تـم حســاب الاتســاق الـاخلي واسـتخدام معامـل الفـا كرونبـاخ، حيث بلغت قيمـة معامـل الثبات للمقياس

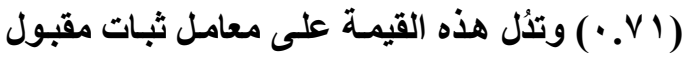

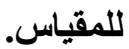

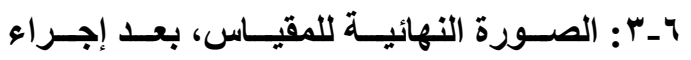
التعديلات اللازمسة في ضسو نتـائج حسـاب الصدق ئق والثبــات تــم التوصـل للصــورة النهائيسة للمقيــاس (ملحقه)، ثم برمجـة المقيـاس باسـتخدام برنـامج Microsoft forum وتهيئة الر ابط الخــاص بـه لتضمينه ضمن مجتمع التعلم الاستقصائي. ع- بطاقة رصد مؤشرات الإنجاز الأكاديمي. يقصد بالإنجاز الأكاديمي مجموع اللارجات التي

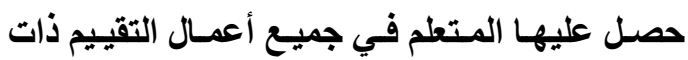

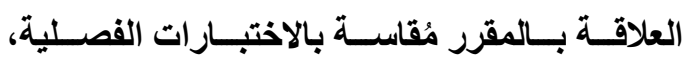


الجمعية المصرية لتكنولوجيا التعليم

r- ؛ : التقدير الكمي لأبعاد البطاقة: تم تقدير أبعاد

البطاقة في ضوء الوزن النسبي المخصص لكل بعد

كما هو موضح بالجدول (V):
- - البعـد الثـاني: نتـائج الطـلاب في المهــام

والتكليفـات وأنشـطة بنـاء مجتمـع الـتعلم

الاستقصائي عبر الويب في ضوء قواعد

تقييم Rubrics لكل مهمة أو نشـاط (بنـاء

لوحة النقاش، بناء المدونة، بناء الويكي).

جدول (v)

\begin{tabular}{|c|c|c|}
\hline التقدير الكمي & الوزن النسبي & 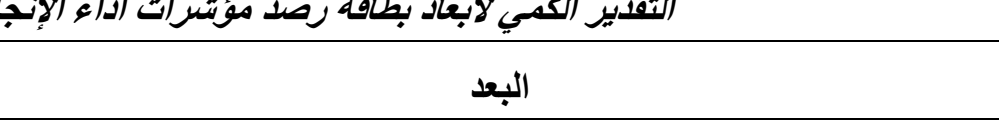 \\
\hline ๑. & $\% \%^{0}$ & نتائج الطلاب في الاختبار الفصلي والنهائي \\
\hline ๑. & $\% \bullet$ & 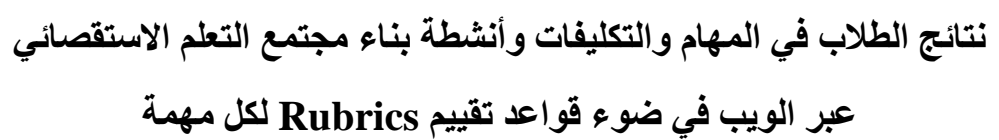 \\
\hline
\end{tabular}

تصنيف بلوم، وكذلك مواعمة قياس مدى تحقق كل هدف من أهداف التعلم المُخطط لها في مقرر نظم إدارة التعلم الإكتروني، ثم صياغة تعليمات الاختبار وكيفية الاجابة ونظام تقدير الدرجات وحسـاب زمن الإنس الاختبـار، ويخصص للاختبـار النهائي (••) درجـة من الدرجة الكلية للمقرر. r- ـ ـ ـ : تصميم استمارة قواعد تقييم أدوات إنشـاء مجتمعـات الـتـطم الاستقصـائي عبـر الويـب التــي أنشـأهما الطـلاب، والتي شـملت (لوحـة مناقشـات) المنتدى، مدونـة، ويكي)، حيث تم تقسيم استمارة

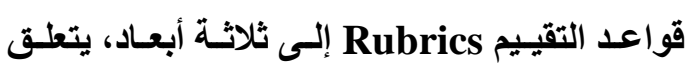
البعد الأول بقواعد تقييم لوحة المناقثـات/ المنتدى ، ويتعلق البعد الثاني بقواعد تقييم المدونـة، أمـا البعد الثالث فيتعلى بقواعد تقييم الويكي، وتم تخصيص
ـ ــ : إعداد الصورة الأولية للأدوات الفرعيـة التي تضـنتها بطاقة رصد مؤثـرات الإنجـاز الأكـاديمي

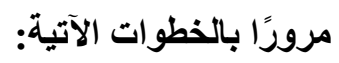

1 ـ ـ ـ : تصميم الاختبار الفصلي، وهو عبارة عن

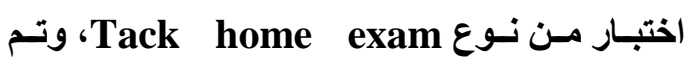
صياغة تعليمـات الاجابـة على فقرات الاختبـار مـع تحديـ موعد الاستـقاقى، وتـم تخصيص عثـرون درجـة مـن الارجـة المخصصـة للأعمـال الفصـلية

r-צ ـ ؛ : تصــميم الاختبــار النهـائي، تــم تصــميم

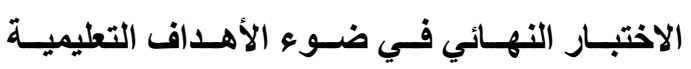
المخطط لهـا في المقـرر، والموضـوعات التـي تــــ تدريسـها للطـلاب، حيث تضـمن أسـئلة موضسوعية وأسئلة مقاليه لضمان قياس مستويات متنوعة وفق

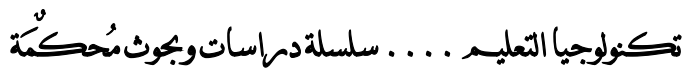


الجمعية المصرية لتكنولوجيا التعليم

د- تطبيق إستراتيجيات التظظيم الذاتي المعززة

للحضــور المعرفـي والاجتمــاعي لتهيئـة

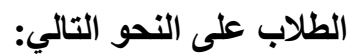

- -

تطبيقها في هذه المرحلة: تخطيط الأهداف

والتوقعات، وإدراك سياق التعلم والامكانات

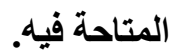

- - إســتراتيجيات تعزيـزز الحضــور المعرفـي

والتـي تضــنت: حـث الطـلاب على كتابـة

توقعاتهم بثـأن الأهداف التعليمية المتوقع

إنجازهـا (عبـر صـفحة ال Wiki الخاصـة

بالمقرر)، وتبادل وجهات النظر بثأن آليات

التقيـيم وأدوات التقيـيم وتوزيـع الـدرجات،

والتعريـف بالجدول الزمنـي لتنفيذ المهـام

والأنثطة الخاصـة بـالمقرر (عبر المنتـى

العـام الخـاص بــالمقرر)، والاجابـة على لــ

$$
\text { أدوات التقييم القبلي. }
$$

- - استراتيجيات تعزيز الحضـور الاجتمـاعي:

تم إنشـاء منتدى وحث الطلاب على إنشـاء

مقطع فيديو تعريفي يتضمن تعريف مرئسي

مختصر عن كل طالب يوضـح فيه التعريف

بنفسـه واهتماماتـه وخبراتـه السـابقة بشـأن

المقرر وموضسوعاته، وحت الطلاب أيضًا

على طرح الأسئلة ذات العلاقـة واستخدام

أدوات التواصل المتزامنة وغير المتزامنة،

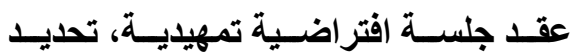

ثلاثـــن درجـة مسن الارجـة المخصصـة للأعمـال

$$
\text { الفصلية وهى (••). }
$$

\section{رابعًا: تجربة البحث.}

- الاستعداد لتنفيذ تجربة البحث، حيث تم مخاطبة عمادة التعلم الإكتروني والتعليم عن بعد بثـأن

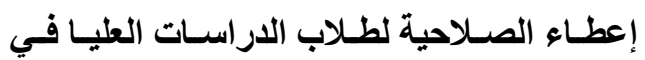
مقرر نظم إدارة التعلم الإكترونسي، ليتمكنوا من إدارة وتحريـر صفحات المقرر وممارسـة نفس الصلاحيات المخصصة لأستاذ المقرر. - - تنفيذ إستراتيجية الامجج بين إستراتيجية التنظيم الأتي للتعلم ومجتمعات الاستقصاء عبر الويب مرورًا بالمراحل الموضحة في الشكل (†) حيث تم تنفيذ الإجراعات الأتية: 1- مرحلة الإعداد/ التفكير (التهيئة): تم تنفيذ هذه المرحلة في الأسبوع الثاني بمعدل يومين في

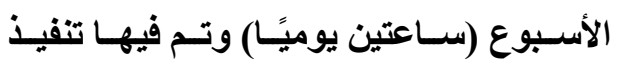

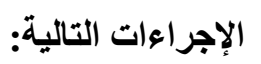

أـ تسـجيل دخـول الطـلاب لنظــام إدارة الـتعلم

\section{Blackboard}

بـ- عقد لقـاء افتراضـي مـع الطـلاب للتعريـف بطبيعة استراتيجية الدمج بين استراتيجية التنظيم الذاتي للتعلم ومجتمعات الاستقصـاء

$$
\text { عبر الويب. }
$$

ج- تطبيق أدوات القياس قبليًا وتثــل مقاييس

(العضـور المعرفـي الاجتمـاعي، التنظيم

الأتي للتعلم، الضغوط الأكاديمية). 
الجمعية المصرية لتكنولوهيا التعليم

د- تنفــذ أنشــة تعزيـز الحضـور المعرفـي

والاجتماعي والتي تضمنت: تقديم الأسئلة

أو محفزات الاستقصـاء، وضـع روابط في

المنتــدى تتضـمن الإحالـة لمصـــ/ مقطـع

فيـديو/ بحـث/ صـفحة ويسب، ويطلب مسن

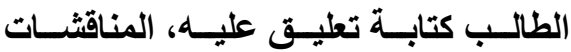

الجماعيـة، عقـــ جلســات افتر اضـية، مـع

مراعـاة التـــكير دائمًَا بأهميـة التثــارك

الاجتمـــاعي مثــل: الـــويكي، المـــونـات،

المنـاقثــات مــع تـوفير إرشــادات الاتاحسة

والوصول والاستخدام.

r- مرحلة التأمل والتقيبم الذاتي (التقيـم وقيـاس

الأداء)، حيث تضمنت هذه المرحلة التلخيص

واستخلاص النتائج وقياس الأداء، وتمت في

الأسـابيع الثـاني عثـر وحتى الخـامس عثـر

وفق خطة التقيم المعتمدة في المقرر، وتم في

هذه المرحلة تنفيذ الإجراءات الأتية:

أ- عقد لقاء افتراضـي مع الطلاب لاستخلاص

النتائج وتقديم العروض التي قام بتنفيذها

الطلاب.

ب- تطبيق إستراتيجيات التنظيم الأتي المعززة

للحضور المعرفي والاجتمـاعي ذات العلاقة

بالتأمل والتقيم الذاتي، مثل طلب تلخيص

ما تم الاستفادة منه في شكل تقريـر ورفعه

على صفحة الويكي أو المدونة التي أنشـأها

الطلب، تكليف كل مجموعة بعمل عرض
معايير المناقشات وقواعد السلوك المرتبطة

بهـا، طـرح الاســلة المفتوحسة ومحفزئ النقاش.

r- - مرحلة الأداء الفعلي (تقديم التعلم الجديد): تم

تنفيذ هذه المرحلة في الأسابيع من الثالث حتى

الحادي عشر من الفصل الدراسـي الثاني للعام

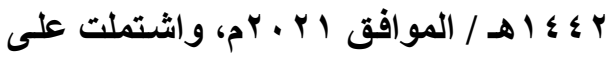

$$
\text { الإجراءات الأتية: }
$$

أـ الاستكثـاف والتقصسي مسن خـلال الوصـول

لمصـــادر الـــتملم والـــروابط المرتبطـــة

بموضـــوعات مقــرر نظـــم إدارة الــتعلم

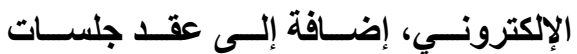

افتر اضــية تضــمنت محاضــرات قصسيرة

وعـروض عمليــة مــن خــلال مشــــاركة

الشاشات بين استاذ المقرر والطلاب.

ب- المناقشـات وتتفيـذ المهـام مـن خـلال تبـادل الآراء ووجهات النظر عبر لوحات النقاش

الخاصة بالمقرر بشأن الموضوعات التي تم

التوصل إليها، وطرح الأسئلة وتنفيذ أنشطة التقييم البنائي، إضـافة إلى عروض عملية افتراضية من خـلال مشساركة الشاشـات بين استاذ المقرر والطلاب. ج- إستراتيجيات التنظيم الذاتي للتعلم التي تـم دمجها ضـمن إجراءات التعلم الاستقصسائي عبر الويب هى: تحليل المهام، إدارة وقت التعلم، طلب الدعم والمساعدات.

تصكنولوجيا التعليـم . . . . سلسلةدماساتوبجوثمُححكمة 
الجمعية المصرية لتكنولوجيا التعليم

$$
\text { تقديمي لأحد الموضـوعات التي تم إعداد الإجابة على السؤال الأول: }
$$

نص السؤال الأول على " مـا معسيير تصـميم

قائمسه بهـا لهـم، وتنفيذ هـا العرض لكـل

اسـتراتيجية قائمسة على اللـمج بـين إسـتراتيجيتي

مجموعـة أمسام زملائهـــم ومسن ثـم تلقــي

التظظيم الذاتي للتعلم ومجتمعـات الاستقصـاء عبر

تعليقات ومقترحات زملائهم على الأداء.

الويـب، علــ الحضــور المعرفـي، والاجتمـــي،

ج- تطبيق أدوات القياس بعديًا وتثمل مقاييس

والإنجاز الأكاديمي، والتعامل مع الضغوط الأكاديمية

(الحضـور المعرفـي الاجتمـاعي، التظظيم

لاى طلاب الاراسات العليا بكلية التربية؟

" وتــم الإجابـة عـن هـذا السـؤال فـي أولاً مـن

الـذاتي للتعلم، الضـفوط الأكاديميـة، رصد

بنود بطاقة الإنجاز الأكاديمي).

خطوات البحث، حيث تم التوصل إلى قائمة المعايير،

والتـي تكونــت مـن (9) معسايير رئيسـية، تُقــاس

$$
\text { باستخدام (• 9 ) مؤشرًا. }
$$

الإجابة عن السؤال الثاني:

نص السؤال الثاني على " ما التصميم التعليمي

لإســتراتيجية مقترحسة قائمسـة علــى الــدمج بـين

إســتراتيجيتي التنظـيم الـــاتي للـتـلم ومجتمعــات الاستقصساء عبر الويـب، على الحضسور المعرفي،

والاجتمــاعي، والإنجـاز الأكـاديمي، والتعامـل مـعـ

الضغوط الأكاديمية لدى طلاب الدراسات العليا بكلية التربية؟"، وتم الإجابة عن هذا السؤال في ثانيًا من خطـوات البحـث، حيـث تـم التوصـل إلـى النمــوذج التصــميم المقتـرح فــي ضــو نمــوذج التصــميم

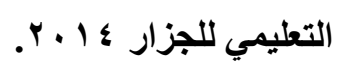

الإجابة عن السؤال الثالث:

\section{خامسساً: التمليل الإهصائي للبيانات.}

تـم اسـتخدام برنـامج SPSS V23 ميث تـم

تطبيق أساليب التحليل الإحصائي الأتية:

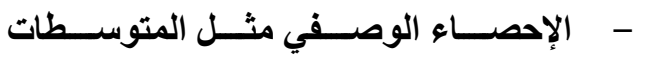

الحســــابية والانحر افــــات المعياريـــــة،

$$
\text { والتكرارات و النسب المئوية. }
$$

- اختبـار t-test للفـروق بـين متوسـطـات

Paired sample مجوعتين مرتبطتين

\section{.t-test}

- اختبار Mann Whitney للفروق بين

$$
\text { مجموعتين مستقلتين. }
$$

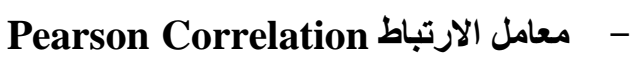

- نسبة الفاعلية لـ McGuigan -

\section{سادسا: عرض نتائج البـــث، ومنـاقشـتها، \\ وتفسيرها.}

نص السؤال الثالث على " ما أثر إستراتيجية قائمة على الدمج بين إستراتيجيتي التنظيم الذاتي للتعلم

فيما يلي عرض للنتائج التي توصل إليها البحث في ضوء تساؤلات البحث على النحو الآتي: 
الجمعية المصرية لتكنولوجيا التعليم

الأكاديمي، ومستوى الضـوط الأكاديمية للى

طلاب الدراسات العليا في كلية التربية.

$$
\text { اختبار صحة الفرض الأول: }
$$

للتحقق من صحة الفرض الأول الذي نص على

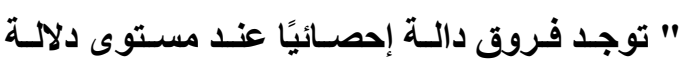

× • . . بـين متوسـط درجـات التطبيـق القبلـي والبعدي لمقيـاس الحضور (المعرفي، الاجتمساعي) لدى طلاب الدراسـات العليـا في كليـة التربيـة"، تم تطبيـق مقيــاس الحضــور فــي بعـــي المعرفـي

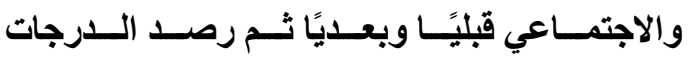

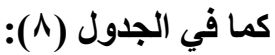
SمعSS V ومالجتها إحصائيًا باستخذام برنامج 23

ومجتمعات الاستقصساء عبر الويب، على الحضور المعرفـي، والاجتمــاعي، والإنجــاز الأكــاديمي، والتعامـلـل مــع الضــوط الأكاديميـة لــــ طـلاب الدراسات العليا بكلية التربية؟"، وللاججابة عن هذا الســؤال أقتـرض البحــث الحـالي الفـروض الأول و الثاني الثالث، وفيمـا يلي إجراءات التحقق مـن صحة هذه الفروض، تم تطبيق أدوات القياس قبليًا وبعـيًا ثـم رصـــ الـــرجات ومعالجتهــا إحصـائيًا باستخدام برنامج SPSS V23 كما يلي: أ- الفروض المتعلقة بفاعلية إستراتيجية الدمج بـين إســتراتيجيتي التنظـيم الـــاتي للـتـطلم ومجتمعات الاستقصاء عبر الويب، في تنمية الحضــور المعرفـي والاجتمــاعي، والإنجــاز

جدول (^)

\begin{tabular}{|c|c|c|c|c|c|c|}
\hline الدلالة & $\mathbf{t}$ & ح.د & $\varepsilon$ & م & التطبيق & الأبعاد \\
\hline$* * \ldots$ & rr.v & $r$. & $\begin{array}{l}r . r v \\
1 . \wedge 4\end{array}$ & $\begin{array}{l}\text { rV.rr } \\
\text { rq.Tr }\end{array}$ & البعدي & المعرفي \\
\hline$* * \ldots$ & $r \cdot . \leqslant q$ & $r$. & $\begin{array}{l}r . r T \\
1.89\end{array}$ & 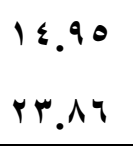 & البعلي & الاجتماعي \\
\hline$* * .$. & $r \varepsilon_{.} . r$. & $r$. & $\begin{array}{l}r .0 \text { L } \\
\text { r.Y }\end{array}$ & $\begin{array}{l}\text { r.rq } \\
\text { or. }\end{array}$ & القبلي & المقياس ككل \\
\hline
\end{tabular}

ا •. . وبالتـالي قبـول الفـرض الأول، حيـث يوجــ من خلال الجدول (^) يتضـح أن قيم "ت" للفروق فـروق بـين متوســات درجــات التطبيـق القبلـي بين متوسـطات درجـات التطبيـق القبلـي والبعـدي والبعدي لمقيـاس العضـور المعرفـي والاجتمـاعي لمقيـاس الحضـور المعرفـي والاجتمــاعي، جـاعت

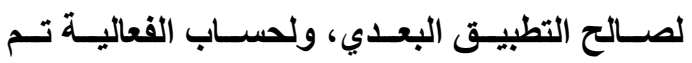

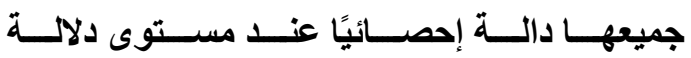

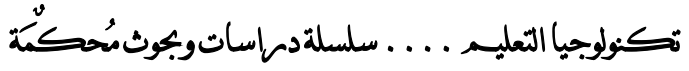


الجمعية المصرية لتكنولوجيا التعليم

الإنجـاز الأكـاديمي لدى طلاب الدراسـات العليـا في

كليـة التربيـة"، تم تنفيــ إستراتيجية التعلم المُنظم

ذاتيًا في مجتمعات الاستقصاء عبر الويب، ثم رصد

درجات الطلاب في استمارة تقدير الإنجاز الأكاديمي

(الاختبارات الفصلية، العملية، المهام والتكليفـات،

الاختبـار النهـائي للمقـرر)، ثـم معالجـة الـدرجات

إحصائيًا باستخدام برنـامج SPSS V V 23 كما في

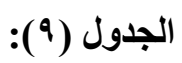

اســتخدام معادلــة نســة الفاعليـة لمـاك جوجيـان McGuigan

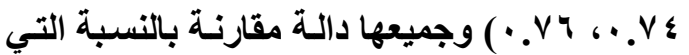

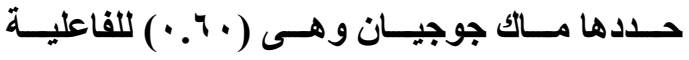
المقبولة. اختبار صحة الفرض الثاني: للتحقق من صحة الفرض الثاني الأي نص على " توجـد فروق دالــة إحصــائيًا عنـــ مستـوى دلالـة

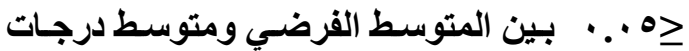
جدول (9)

نتائج حساب دلالة الفروق بين المتوسط الفرضي ومتوسطات درجات الإنجاز الأكاديسي لدى طلاب الدراسات العليا في كلية التربية.

\begin{tabular}{|c|c|c|c|c|c|c|}
\hline الدلالة & $\mathbf{t}$ & المتوسط & ح.د & الانحر اف & المتوسط الفعلي & الإنجاز الأكاديمي \\
\hline$* * .$. & $1 \leq .87$ & 7. & $r$. & $r .09$ & 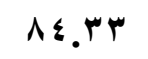 & البعدي \\
\hline
\end{tabular}

للتحقق من صحة الفرض الثالث الأي نص على

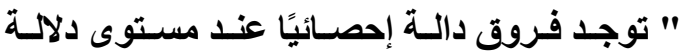

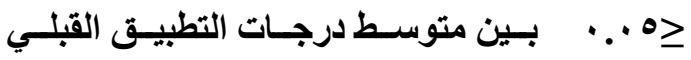
و البعدي لمقياس الضغوط الأكاديمية في بيئة التعلم عبر الويـب لـدى طـلاب الدراسـات العليـا في كليـة التربية"، تم تطبيق المقيساس قبليًا وبعديًا ثم رصد

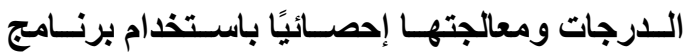
SPSS V 23
للفروق بين المتوسط الفرضي ومتوسطات درجـات الإنجاز الأكاديمي، دالة إحصـئيًا عند مستوى دلالية • . . وبالتالي قبول الفرض الثاني، حيث يوجد فروق . بين المتوسط الفرضس ومتوسطات درجـات الإنجاز الأكـاديمي، كمــا أن نسـبة الفاعليـة لمـاك جوجيـان McGuigan بلغت( آ. · ) وهى مقبولة في ضوء القيمة التي حددها ماك جوجيان. 
الجمعية المصرية لتكنـولوجيا التعليم

جدول ( )

\begin{tabular}{|c|c|c|c|c|c|c|}
\hline الالالة & $\mathbf{t}$ & ح.د & $\varepsilon$ & r & التطبيق & 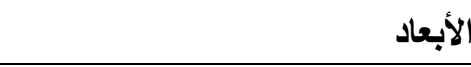 \\
\hline$* * .$. & 17.50 & $r$. & $\begin{array}{l}1.11 \\
r .74\end{array}$ & 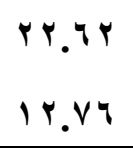 & 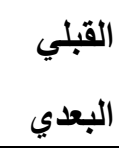 & طبيعة بيئات التعلم عبر الويب \\
\hline$* * .$. & Ir.or & r. & $\begin{array}{l}1.94 \\
1.91\end{array}$ & $\begin{array}{l}\text { IV.OV } \\
1 . .0 Y\end{array}$ & 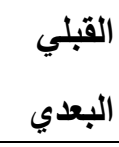 & والمناقشــات و التفــاعلات التعليميـة \\
\hline$\because 9$ & 1.20 & r. & $\begin{array}{l}1 . r 9 \\
1.14\end{array}$ & $\begin{array}{l}9.74 \\
1.71\end{array}$ & 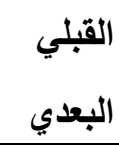 & التواصل مع أستاذ المقرر والأقران \\
\hline$* * .$. & $\mid \leq . M$ & r. & $\begin{array}{l}\because . \leqslant \varepsilon \\
1 . r \Lambda\end{array}$ & $\begin{array}{l}14 . v 4 \\
1 . .00\end{array}$ & 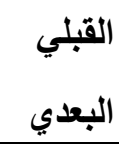 & طبيعة أنشطة التقيمٍ عبر الويب \\
\hline$* * .$. & $1 V .0 \mathrm{~V}$ & $r \cdot$ & $\begin{array}{l}1 . r \Lambda \\
1 . r\end{array}$ & 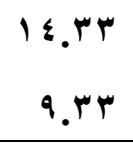 & البعلي - البلي & مستوى الاعم و المساعدات \\
\hline$* * .$. & $M I . V \leq$ & r. & $\begin{array}{r}r .7 \\
0.1 \leq\end{array}$ & $\begin{array}{l}V V . q . \\
01 . \% \wedge\end{array}$ & 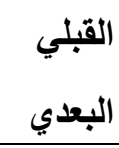 & المقياس ككل \\
\hline
\end{tabular}

لـم تحقق مستوى الدلالـة المطلوبـة، كمـا أن نسبة

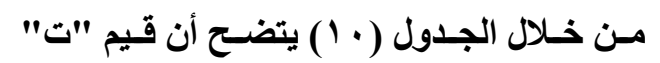
الفاعلية لماك جوجيان McGuigan بلغت( ه ه • ) للفـروق بـين متوسـطات درجـات التطبيـق القبــي وهـى مقبولــة في ضـوء القيمـة التـي حددها مـاك والبعدي لمقياس الضـغوط الأكاديمية (الكلي)، دالة

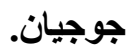

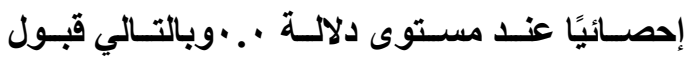
الإجابة على السؤال الرابع.

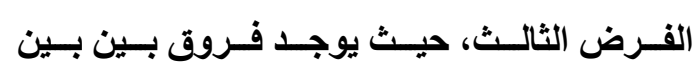
نص السؤال الرابع على " مـا أثر استراتيجية مقترحة قائمة على الامجج بين إستراتيجيتي التنظيم

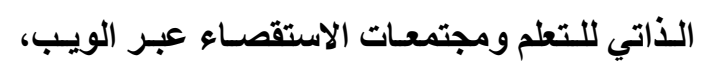
على الحضـور المعرفي، والاجتمــاعي، والإنجـاز

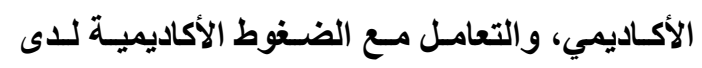
متوسطات درجات التطبيق القبلي والبعدي لمقياس

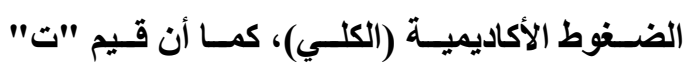
للفروق بين مصادر الضغوط الأكاديمية في التطبيق القبلي والبعدي جاءت جميعها دالة لصـالح التطبيق البعدي عدا الفروق المرتبطة بالتواصل مـع أستاذ المقرر باعتباره مصدرًا للضـوط الأكاديمية، فإنها 
الجمعية الهصرية لتكنولوجيا التعليم

طلاب الداسات العليا ترجع لتأثير مستوى التنظيم

الذاني للتعلم (مرتفع، مـنخفض) للايهم، تم رصد درجـات الطـلاب، ثـم اسـتخدام اختبـار الاحصــاء

Mann Whitney اللامعلمي المعـروف باسـم لمعرفـة الفروق بين درجـات (هץ\%) الأعلى في مستوى التنظيم الأتي للتعلم، وفئة (0\%\%) الأدنى في مستوى التنظيم الذاتي للتعلم كما هو موضـح في

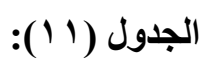

طلاب الدراسـات العليـا بكليـة التربيـة ترجـع لتأثثر مستوى التنظيم الذاتي للتعلم (مرتفع، مـنخفض) لـديهز؟"،وتمت الإجابـة عـن هـذا السـؤال باختبـار صحة الفـروض الرابـع والخـامس والسـادس على لـ

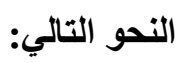
اختبار صحة الفرض الرابع: للتحقق من صحة الفرض الرابع والذي نص على " توجد فروق ذات دلالة إحصائيًا عند مستوى دلالة >0 . . • في العضور المعرفي والاجتماعي بين

جدول (1)

نتائج حساب دلالة الفروق في الحضور المعرفي والاجتماعي بين الطلاب مرتفعي ومنخفضي التنظيم الذاتسي للتعلم

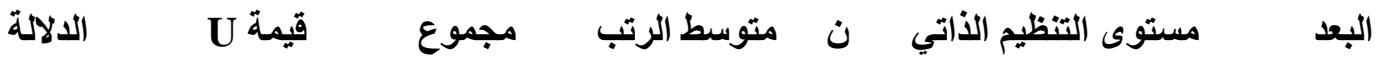

\begin{tabular}{|c|c|c|c|c|c|c|}
\hline & & الرتب & & & للتعلم & \\
\hline دالة عند & \multirow{2}{*}{0.0} & r..0 & $7 . \cdot 1$ & 7 & منخفض & \multirow{2}{*}{ المعرفي } \\
\hline$\because 0$ & & 01.0 & $\Lambda . \cdot r$ & 7 & مرتفع & \\
\hline دالة عند & \multirow{2}{*}{ r.o } & $r \leqslant .0$ & $\varepsilon . \cdot 1$ & 7 & منخفض & \multirow{2}{*}{ الاجتماعي } \\
\hline .1 & & or.o & $1.9 r$ & 7 & مرتفع & \\
\hline
\end{tabular}

(r.๑) Whitney 1. . ، ، ويناءً عليه تم قبول الفرض الرابع. اختبار صحة الفرض الخامس:

للتحقق من صحة الفرض الرابع والذي نص على " توجد فروق ذات دلالة إحصائيًا عند مستوى

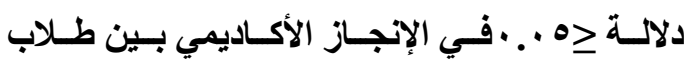
الاراسات العليا ترجع لتأثير مستوى التنظيم الذاتي للتعلم (مرتفع، منخفض) للايهم، تم رصد درجـات
من خلال الجدول (1 1 ) يتضح وجود فروق دالة إحصـائيًا عنــ مستوى ه . . · بين الطلاب مرتفعي ومنذفضــي التظظيم الــذاتي للـتعلم فـي الحضـور المعرفي، حيث بلغت (U) لـ Mann Whitney (0 . .0) وهى دالـة إحصـائيًا عنــ مستوى ه ... ، كما يوجد فروق دالـة إحصـائيًا عند مستوى 1 +. بين الطلاب مرتفعي ومنخفضي التنظيم الأتي للتعلم في الحضور الاجتماعي، حيث بلغت (U) لـ Mann 
الجمعية المصرية لتكنولوجيا التعليم

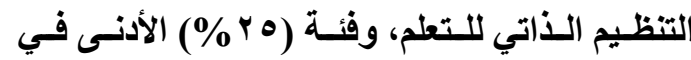

الطـلاب، ثم اسـتخدام اختبـار الاحصـاء اللامعلمي

مستوى التنظيم الذاتي للتعلم كمـا هو موضـح في

المعسروف باسـم Mann Whitney لمعرفـة

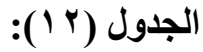

الفروق بين درجات (\% \% \% الأعلى في مستوى

جدول (r) ( )

نتائج حساب دلالة الفروق في الإنجاز الأكاديمي بين الطلاب مرتفعي ومنخفضي التنظيم الذاتسي للتعلم

\begin{tabular}{|c|c|c|c|c|c|c|}
\hline الدلالة & قيمة U & مجموع & متوسط الرتب & ن & مستوى التنظيم الذاتي & البعد \\
\hline دالة عند & & $r r .$. & $r . \wedge r$ & 7 & منخفض & \\
\hline مستوى & r... & 00. & $9.1 \mathrm{~V}$ & 9 & مرتفع & الأكاديمي \\
\hline
\end{tabular}

للتحقق من صحة الفرض الرابع والذي نـص

من خلال الجدول (r ا ) يتضح وجود فروق دالة

على " توجد فروق ذات دلالة إحصائيًا عند مستوى هون

إحصـائيًا عند مستوى ه . . · بين الطلاب مرتفعي

دلالـة >0 . . .في مستوى الضـغوط الأكاديميـة بين

ومنخفضـــي التنظـيم الـــاتي للـتعلم فــي الإنجــاز

طلاب الدراسات العليا ترجع لتأثير مستوى التنظيم

Mann Whitney الأكاديمي، حيث بلغت (U) لـ

الذاتي للتعلم (مرتفع، مـنخفض) للايهم، تـم رصد

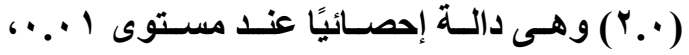

درجــات الطــلاب، ثـــم اســتخدام اختبـار الاحصــاء

ويناءً عليه يتم قبول الفرض الخامس، حيث توجد

Mann Whitney اللامعلمـي المعـروف باسـم فروق دالة إحصائيًا عند مستوى ه ه. . • في الإنجاز

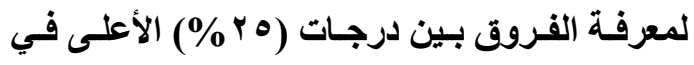
الأكاديمي ترجع لتأثير مستوى التنظيم الذاتي للتعلم مستوى التنظيم الأاتي للتعلم، وفئة (0Y\%\%) الأدنى (مرتفع، منخفض). في مستوى التنظيم الذاتي للتعلم كما هو موضـح في

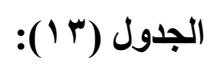

اختبار صحة الفرض السادس:

جدول (r) (1)

نتأتج حساب دلالة الفروق في مستوى الضغوط الأكاديمية بين الطلاب مرتفعي ومنففضي التنظيم الذاتـي للتعلم

\begin{tabular}{|c|c|c|c|c|c|c|}
\hline & & الرتب & & & للتعلم & \\
\hline دالة عند & & o... & A.rr & 7 & منخفض & \\
\hline مستوى & $7.0 Y$ & $r \Lambda_{.} \cdot$ & ะ.7V & 7 & مرتفع & \\
\hline
\end{tabular}


الأكاديمي، ومستوى الضغوط الأكاديمية لاى طلاب الاراسات العليا في كلية التربية، والحضور المعرفي والاجتمـــاعي، والإنجـــاز الأكــاديمي، ومســتوى الضغوط الأكاديمية للدى طلاب الاراسـات العليا في كلية التربية؟"، تم الإجابة عن هذا السؤال من خلال التحقق من صحة الفروض السابع والثامن والتاسـع

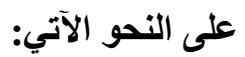
اختبار صحة الفرض السابع. للتحقق مـن صـحة الفـرض السـابع الذي نـص على " توجــ علاقـة ارتباطيـة دالــة إحصـائيًا عنــــ مستوى \ه •. · بين الاستراتيجية القائمة على دمج اسـتراتيجيتي التنظـيم الــاتي للـتطلم ومجتمعسات الاستقصـــاء عبـر الويــب، والحضــور المعرفـي والاجتمـاعي لـدى طلاب الدراسـات العليـا في كليـة التربية "، تم رصد درجـات تطبيق المقياس بعديًا، SPSS V ومعالجتها إحصائيًا باستخدام برنامج 23 كما في الجدول (ع ا ):
من خلال الجدول (r I ) يتضح وجود فروق دالة إحصـائيًا عنـــ مستوى ه . . · بين الطلاب مرتفعي ومنخفضــي التنظـيم الـذاتي للـتعلم فـي الضــفوط الأكاديمية، حيث بلغت (U) لـ Mann Whitney

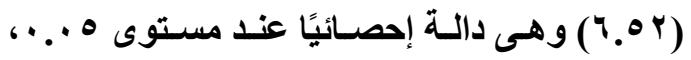
ويناءً عليه يتم قبول الفرض السـادس، حيث توجد فروق دالة إحصائيًا عند مستوى ه .. • في الضغوط الأكاديمية ترجع لتأثير مستوى التنظيم الذاتي للتعلم (مرتفع، منخفض). بـ الفـروض المتعلقـة بالعلاقـة الارتباطيـة بـين الإسـتراتيجية المقترحسة، والحضسور المعرفي والاجتمـاعي، والإنجـاز الأكساديمي، ومسـتوى الضغوط الأكاديمية لاى طلاب الارسات العليا في كلية التربية. الإجابة على السؤال الخامس. نــص الســؤال الخــامس عــى " مــــ العلاقــة الارتباطيــة بـين إســتراتيجية الـــمج المقترحسة، والحضـــور المعرفــي والاجتــــاعي، والإتجـــاز 
الجمعية المصرية لتكنولوجيا التعليم

جدول (\& )

\begin{tabular}{|c|c|c|c|c|}
\hline \multicolumn{2}{|c|}{ الحضور الاجتماعي } & \multicolumn{2}{|c|}{ الحضور المعرفي } & \multirow[b]{2}{*}{ إستراتيجيات التنظيم الذاتي للتعلم } \\
\hline الالالة & الارتباط معامل & الدلالة & معامل الارتباط & \\
\hline 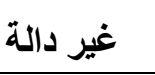 & $(\cdot . r q 1)-$ & 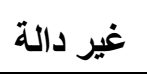 & $(\cdot .00)-$ & تخطيط الأهداف والتوقعات \\
\hline 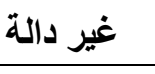 &.$\% 11$ & دالة & $* * .07 r$ & إدراك مجتمع الاستقصاء عبر الويب \\
\hline 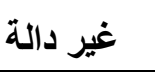 & $\because r \ldots$ & دالة & $* * . .00$ & تنظيم وتحليل المهام والأنثطة الاستقصائية \\
\hline 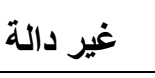 & $(\cdot \cdot \wedge)-$ & 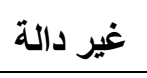 & $\cdot r r \cdot$ & إدارة وقت التعلم \\
\hline 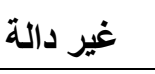 & $\because 9$ & 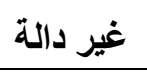 & $\because$ rvo & طلب الدعم والوصول للمصادر \\
\hline 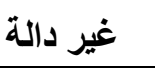 & $(\cdot . r \mu v)-$ & 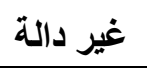 & $(\cdot .1+1)-$ & التأمل والتقييم الذاتي \\
\hline 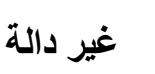 & $\because \cdot r$ & دالة & $* .0 r \varepsilon$ & المقياس ككل \\
\hline
\end{tabular}

مجتمع الاستقصاء عبر الويب، تنظيم وتحليل

المهــام والأنثـطة الاستقصـائية) والحضـور

المعرفي.

- وجـود علاقـة ارتباطيـة موجبـة وغيـر دالــة

إحصـائيًا بـين إسـتراتيجيات التنظيم الـذاتي

للــتعلم (إدارة وقـــت الــتعلم، طلــب الـــــمم

والوصول للمصادر) والحضور المعرفي.

- وجـود علاقـة ارتباطيـة ســالبة وغيـر دالــة

إحصائيًا بين إستراتيجيات النظيم الذاتي للتعلم

(تخطيط الأهداف والتوقعـات، التأمل والتقييم

$$
\text { الأتي) والحضور المعرفي. }
$$

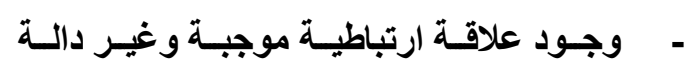

إحصـائيًا بـين إسـتراتيجيات التنظيم الـذاتي

للتعلم (إدراك مجتمع الاستقصاء عبر الويب،

$r \cdot V$
مسن خـلال الجـدول ( ؛ 1) يتضـح وجـود علاقـة

ارتباطية موجبة ودالة إحصائيًا عند مستوى دلالـة

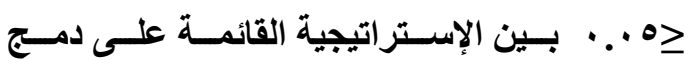
إسـتراتيجيتي التنظـيم الـذاتي للـتعلم ومجتمعـات الاستقصـاء عبر الويـب، والحضـور المعرفي للدى

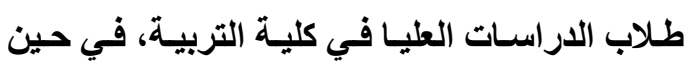
وجدت علاقة ارتباطية ضعيفة وغير دالة إحصائيًا بين الإسـتراتيجية القائمسة على دمـج استراتيجيتي

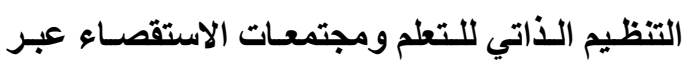
الويب، والحضور الاجتمـاعي، وبنـاء عليه تم قبول

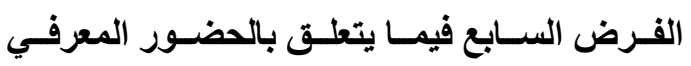
ورفضه فيما يتعلق بالحضور الاجتماعي، كما يتضح الآتي: - وجود علاقة ارتباطية موجبة ودالـة إحصـائيًا بين استراتيجيات التنظيم الذاتي للتعلم (إدراك

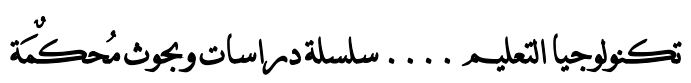


الجمعية المصرية لتكنولوجيا التهليم

للتحقق من صحة الفرض الثامن الأي نص على " توجد علاقة ارتباطيـة دالـة إحصسائيًا عند مستوى

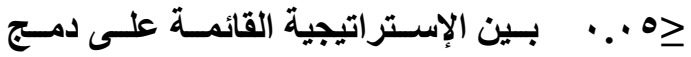

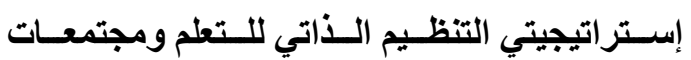
الاستقصـاء عبر الويـب، والانجـاز الأكـاديمي لـدى طلاب الدراسـات العليا في كليـة التربية "، تم رصد درجات تطبيق المقيـاس بعديًا، ومعالجتها إحصـائيًا باستخدام برنـامج SPSS V 23 كمـافي الجدول
تنظيم وتحليل المهام والأنشطة الاستقصسائية، طلب الـدعم والوصـول للمصـادر) والحضـور الاجتماعي. - وجـود علاقة ارتباطيـة سـالبة وغيـر دالـة إحصـائيًا بـين إســر اتيجيات التظظـيم الـذاتي للتعلم (تخطيط الأهداف والتوقعات، إدارة وقت الـتعلم، التأمـلـل والتقيـيم الـذاتي) والحضـور الاجتماعي. اختبار صحة الفرض الثامن.

\begin{tabular}{|c|c|c|}
\hline \multicolumn{2}{|c|}{ الإنجاز الأكاديمي } & \multirow{2}{*}{ إستراتيجيات التظظيم الذاتي للتعلم } \\
\hline 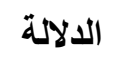 & 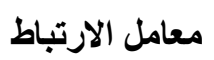 & \\
\hline 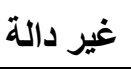 & .191 & تخطيط الأهداف والتوقعات \\
\hline 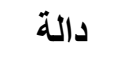 & $* * . .71 \%$ & إدراك مجتمع الاستقصاء عبر الويب \\
\hline دالة - مالة & $* . . \varepsilon r$ & تتظيم وتحليل المهام والأنشطة الاستقصائية \\
\hline غير دالة & $\cdot r \cdot \Lambda$ & إدارة وقت التعلم \\
\hline 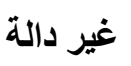 & $\cdot . r \varepsilon 0$ & طلب الدعم والوصول للمصادر \\
\hline غيز دالة & $\because 1 \leq r$ & التأمل والتقييم الذاتي \\
\hline دالة - مالة & $* * .07 r$ & المقياس ككل \\
\hline
\end{tabular}

تـم قبول الفرض الثـامن، كمـا يتضـح وجود علاقة مسن خـلال الجـدول (0) يتضـح وجـود علاقـة ارتباطية موجبة قويـة ودالـة إحصـائيًا عند مستوى ارتباطية موجبـة قويـة ودالـة إحصسائيًا عند مستوى دلالة \ه . . • بين إستراتيجيات التتظيم الأاتي للتعلم دلالـة \ه . . بين الإستراتيجية القائمسة على دمـج (إدراك مجتمــع الاستقصــاء عبـر الويسب، تنظـيم إســتراتيجية التنظــيم الـــاتي للــتملم ومجتمعسـات وتحليـل المهـام والأنشـة الاستقصـائية) والإنجـاز الاستقصـاء عبر الويـب ، والإنجـاز الأكساديمي لـدى الأكـاديمي، في حين توجد علاقة ارتباطيـة موجبة طلاب الدراسات العليا في كلية التربية، وبنـاء عليه 
الجمعية المصرية لتكنولوجيا التهليم

مستوى \ه • . • بين الاستراتيجية القائمة على دمج

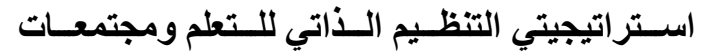

الاستقصــاء عبــر الويــب، ومســتوى الضــنوط

الأكاديميـة لـدى طـلاب الاراسـات العليـا فـي كليـة التربية "، تم رصد درجات تطبيق المقيـاس بعديًا،

SPSS V 23 ومعالجتها إحصائيًا باستخدام برنامج كما في الجدول (7 (1):
وغير دالة إحصائيًا بين إستراتيجيات التنظيم الذاتي للـتعلم (تخطـيط الأهــاف والتوقعـات، إدارة وقـت التتعلم، طلـب الـدعم والوصـول للمصــادر، التأمسل والتقيم الأتي) والإنجاز الأكاديمي. اختبار صحة الفرض التاسع. للتحقق مسن صسحة الفرض التاسـع الذي نص على " توجد علاقـة ارتباطيـة دالـة إحصـائيًا عنــ جدول (7 )

نتائج حساب معامل الارتباط بين إستراتيجيات التنظيم الأتسي للتعلم ومستوى الضغوط الأكادبيةية مستوى الضغوط الأكاديمية

\begin{tabular}{|c|c|c|}
\hline 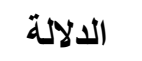 & 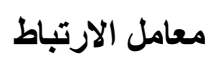 & \\
\hline دالة & $(* .017)-$ & تخطيط الأهداف والتوقعات \\
\hline 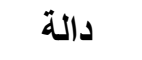 & $(* * \cdot . V \mu \bullet)-$ & إدراك مجتمع الاستقصاء عبر الويب \\
\hline غير دالة & $(\cdot . r q \wedge)-$ & تنظيم وتحليل المهام والأنشطة الاستقصائية \\
\hline غير دالة & $(\cdot . r q \cdot)-$ & إدارة وقت التعلم \\
\hline غير دالة & $.1 \mathrm{rV}$ & طلب الدعم والوصول للمصادر \\
\hline غير دالة & $(\cdot \cdot 7 \wedge)-$ & التأمل والتقييم الذاتي \\
\hline 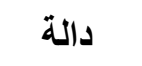 & $(\cdot r q \wedge *)-$ & المقياس ككل \\
\hline
\end{tabular}

علاقة ارتباطيـة سـالبة ودالـة إحصـائيًا عند مستوى مسن خـلال الجـول (7 1 ) يتضـح وجـود علاقة دلالة \ه . . • بين إستراتيجيات التظظيم الذاتي للتعلم ارتباطيـة سـالبة دالـة إحصـائيًا عنــ مسـتوى دلالـة (تخطـــيط الأهـــــاف والتوقعـــات، إدراك مجتمــعـع

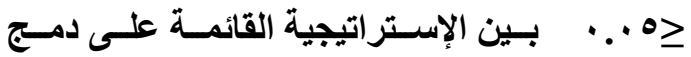
الاستقصـاء عبر الويسب)، وتوجد علاقـة ارتباطيـة إســتراتيجية التتظــيم الــذاتي للــتعلم ومجتمعــات سالبة وغير دالة إحصائيًا بين إستراتيجيات (تتظيم وتحليـل المهـام والنشـة الاستقصـائية، إدارة وقت التعلم، التأمل والتقييم الأاتي) والضغوط الأكاديمية، الاستقصساء عبر الويب، والضـغوط الأكاديميـة لدى طلاب الدراسـات العليا في كلية التربية، وبنـاء عليه تم قبول الفرض التاسع، كمـا أثـارت النتائج لوجود 
الجمعية المصرية لتكنولوجيا التهرليم

اختبار صحة الفرض العاثر.

للتحقق من صحة الفرض العاثر الذي نص على أنه

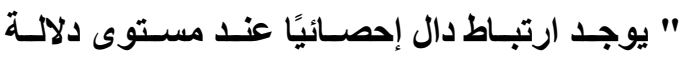

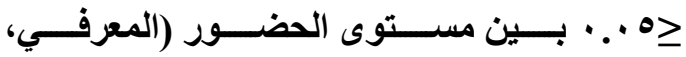

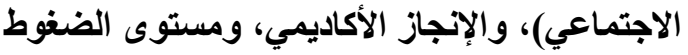
الأكاديميـة للدى طـلاب اللاراسـات العليـا فـي كليـة

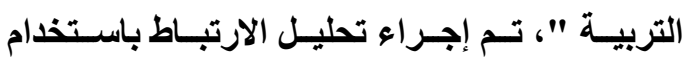
برنامج SPSS V23 كما هو موضح في الجدول :(IV)
وتوجد علاقة ارتباطية موجبة ضعيفة وغير دالـة إحصائيًا بين إستراتيجية التنظيم الذاتي للتطلم (طلب الاعم و الوصول للمصادر) و الضغوط الأكاديمية. الإجابة على السؤال السادس.

نص السؤال السـادس على " مـا العلاقةـة بين مستوى الحضور (المعرفي، الاجتماعي)، والإجباز الأكاديمي، ومستوى الضغوط الأكاديمية للى طلاب الاراسات العليا في كلية التربية؟"، تم الإجابة عن

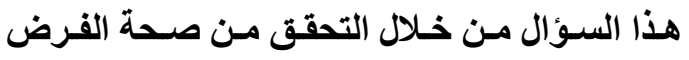

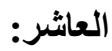

جدول(IV)

نتائج حساب معاملات الارتباط بين مستوى الحضور المعرفي والاجتماعي، والإججاز الأكاديي، ومستوى الضنوط الأكاديمية.

\begin{tabular}{|c|c|c|c|}
\hline الضغوط الأكاديمية & الإنجاز الأكاديمي & الحضور الاجتماعي & \\
\hline$(\cdot r \wedge \downarrow)-$ & $* * ., V \Psi V$ & $* . .0 . v$ & الحضور المعرفي \\
\hline$\because \cdots$ & $\because \wedge$ & - & الحضور الاجتماعي \\
\hline$*(\cdot . \leqslant \leqslant V)-$ & - & - & الإنجاز الأكاديمي \\
\hline
\end{tabular}

- وجود علاقة ارتباطية سـالبة ودالة إحصائيًا

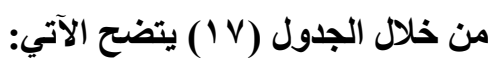

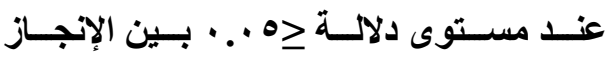
الأكاديمي والضغوط الأكاديمية. وبناءً عليه تم قبول الفرض العاشر فيما يتطلق

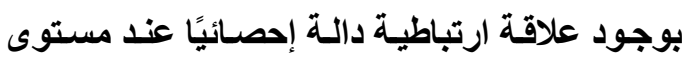

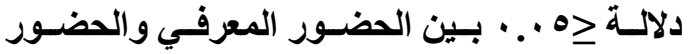
الاجتماعي والضغوط الأكاديمية، وكنلك بين الإنجاز

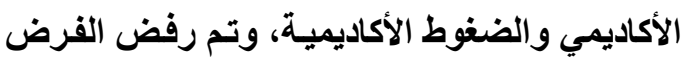
فيما يتعلق بوجود علاقة ارتباطية دالة إحصائيًا عند
- مجـود علاقـة ارتباطيـة موجبـة قويـة ودالـة

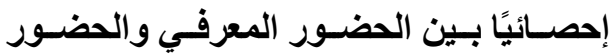
الاجتماعي والإنجاز الأكاديمي، ووجود علاقة ارتباطيـة سـالبة وغيـر دالــة إحصـائيًا بـين الحضور المعرفي والضغوط الأكاديمية. - وجود علاقة ارتباطية موجبة ضعيفة وغير

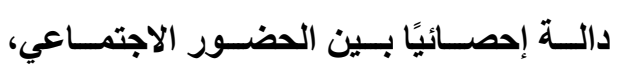
والإنجاز الأكاديمي والضغوط الأكاديمية. 
الجمعية المصرية لتكنولوجيا التعليم

أثنــاء التعلم عبر الويـب؟"، تـم الإجابـة عن هـذا

مسـتوى دلالــة >0 . . بـين الحضـور الاجتمـاعي

الســؤال مــن خــلال تطبيـق المقيــاس وحســاب

والإنجاز الأكاديمي و الضغوط الأكاديمية.

التكرارات والنسب المئوية لاستجابات الطلاب على

الإجابة على السؤال السابع.

بنود القسم الثالث في مقياس الضـغوط الأكاديميـة،

كما هو موضح في الجدول (1 (1):

نـص السـؤال السـابع على " مـا انطباعـات طـلاب

الدراسـات العليـا عندما يواجهون ضغوط أكاديميـة

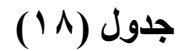

التكرارات والنسب المئوية لإستراتيجيات المواجهة التي بيتخدمها الطلاب للتعامل مع الضغوط الأكاديمية المصاحبة للتعلم في بيئات عبر الويب

\begin{tabular}{|c|c|c|c|c|}
\hline الترتيب & $\%$ & ك5 & \multicolumn{2}{|l|}{ 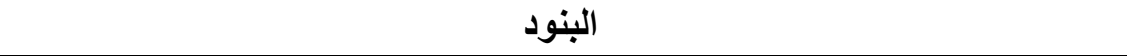 } \\
\hline \multicolumn{5}{|c|}{ عندما أشعر بضغوط أكاديمية أثناء التعلم عبر الويب فأنني: } \\
\hline$r$ & $\% q$. & 19 & أحصل على بعض الوقت للهذوء ثم العودة لإكمال المهام المطلوبة مني. & $\bullet$ \\
\hline r & $\% 90$ & r. & أعيد التفكير في تجزئـة وتفصيل الخطوات والإجراءات التي يجب أن أقوم بها & • \\
\hline r & $\% 90$ & r. & أبحـث عـن المعلومــات والمصــادر التـي تسـاعدني على إنجـاز تعلمـي بالثــل & $\bullet$ \\
\hline 1 & $\% 1 \cdots$ & rl & وأطلحع على بعض الأدلـة والإرشـادات التي تسـاعدني على استيعاب بيئة التعلم & \\
\hline$\bullet$ & $\% \wedge 1$ & iv & أحضر ورشة عمل أو دورة تدريبية لزيـادة كفاعتي في مهار ات استخدام بيئات & \\
\hline$\wedge$ & $\% 19$ & $\varepsilon$ & أقتـع نفسـي بـأن المهـام كثيـرة وبالتـالي عـدم إنجـاز بعضـها، أو إنجازهــا دون & \\
\hline 7 & $\% \vee 7$ & 17 & أعتبر أن الصعوبات التي أوجهها بمثابة تحدي يدفعني لمزيد من الجهذ للإنجاز. & $\bullet$ \\
\hline$\varepsilon$ & $\% \wedge 0$ & 11 & أتثــارك مـع زملائسي الأهـداف والتوقعسات والخبـرات السـابقة لتقليـل الأعبـاء & \\
\hline$r$ & $\% 9$ & 19 & أطلب من أستاذ المقرر أو من زملائي مساعدتي وتقديم الدعم لي. & • \\
\hline
\end{tabular}


الجمعية المصرية لتكنولوجيا التهليم

\begin{tabular}{|c|c|c|c|c|}
\hline الترتيب & $\%$ & ك & 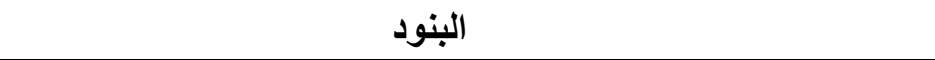 & \\
\hline$\bullet$ & $\% \wedge 1$ & $1 \mathrm{~V}$ & اهتم بتشجيع ذاتي كلما أنجزت جزء من المهام المطلوبة مني. & $\bullet$ \\
\hline$\bullet$ & $\% \wedge 1$ & $1 \mathrm{~V}$ & أعيد النظر في تخطيط أهداف التعلم وترتيب أولوياتي. & $\bullet$ \\
\hline V & $\%$ & 7 & أقلل من توقعاتي ومستوى المعايير التي حددتها من قبل لأدائي للمهام. & $\bullet$ \\
\hline 9 & $\% \vee 7$ & 17 & أعيد ترتيب وقت التعلم المخصص لأداء المهام المطلوية مني. & $\bullet$ \\
\hline
\end{tabular}

المعرفي والاجتمـاعي، والإنجـاز الأكساديمي،

مسن خـلال مسا سـبـق يمكـن اسـتخلاص النتـائج

والضغوط الأكاديمية.

الأتية:

- وجود علاقـة ارتباطيـة موجبـة دالـة إحصـائيًا

- وجود فروق دالة إحصـائيًا عند مستوى دلالـة

بين استراتيجيات التنظيم الذاتي للتعلم ككل، ه • • • بين متوسطات درجات التطبيق القبلي

والحضـور المعرفي، الإنجـاز الأكساديمي، وأن والبعـــي لمتغيــرات: الحضـــور المعرفــي

استراتيجيات (إدراك مجتمـع الاستقصـاء عبر

الويـب، تنظـيم وتحليـل المهـــام والأنثــة الاستقصائية) هما أكثر الاستراتيجيات ارتباطًا والاجتمــاعي، الإنجـاز الأكسـاديمي، الضــوط الأكاديمية لصالح التطبيق البعدي نتيجة تأثير الإسـتراتيجية القائمسة على دمـج إستراتيجيتي إيجابيًا بالحضور المعرفي والإنجاز الأكاديمي. - عدم وجود علاقة ارتباطية دالـة إحصائيًا عند

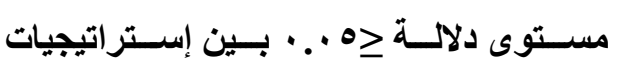
التنظيم الذاتي للتعلم ومجتمعسات الاستقصساء عبر الويب لاى طلاب الدراسات العليا في كلية التربية. التنظـــيم الـــذاتي للـتـعلم كـــل، والحضـــور الاجتماعي. - وجود علاقة ارتباطيـة سـالبة ودالـة إحصـائيًا عند مستوى دلالهة \ه . . • بين إستراتيجيات

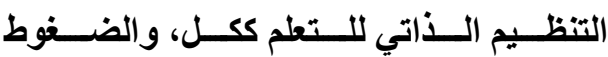
الأكاديمية، وأن إستراتيجيات (تخطيط الأهداف والتوقعــات، إدراك مجتمـع الاستقصــاء عبـر الويب) همـا أكثر الإستراتيجيات إسـهامًا في

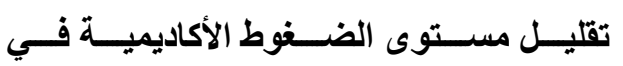
مجتمعات الاستقصاء عبر الويب. - وجـود فاعليـة (مُقاسـه بنسبة الفاعليـة لمـاك جوجيـان ) الإسـتر اتيجية القائمسة على دمـج إستراتيجية التظظيم الذاتي للتعلم ومجتمعـات الاستقصــاء عبـر الويـب بالنسـبة لمتغيـرات: الحضــور المعرفـي والاجتمــاعي، والإنجــاز الأكساديمي، والضـغوط الأكاديميـة لـدى طـلاب الار اسات العليا في كلية التربية. - وجود فروق دالة إحصائيًا بين الطلاب مرتفعي ومنخفي التنظيم الذاتي للتعلم في الحضور 
الجمعية المصرية لتكنـولوجيا التهليم

المعرفي والاجتمـاعي، الإنجاز الأكاديمي، الضغوط الأكاديمية، لصالح التطبيق البعدي، نتيجة استخدام الإستراتيجية القائمة على دمـج إستراتيجية التنظيم

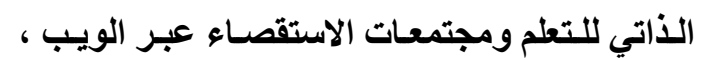
كما أثـارت النتائج إلى فاعليـة الإستراتيجية القائمسة عـى دمــج إســتراتيجية التنظـيم الـــاتي للـتعلم ومجتمعسات الاستقصـاء عبـر الويسب، فـي تنميـة الحضور المعرفي والاجتماعي، والإنجاز الأكـاديمي، ومهارات التعامل مع الضغوط الأكاديمية لدى طلاب الاراسات العليا في كلية التربية، ويمكن تفسير هذه

$$
\text { النتائج على النحو التالي: }
$$

وفقًا لنتائج الفرض الأول والأي تم قبوليه، حيث

أشثارت النتائج إلى فاعلية الإستراتيجية القائمة على دمج إستراتيجيتب التنظيم الذاتي للتعلم ومجتمعات الاستقصاء عبر الويب في تنمية الحضور المعرفي والاجتمـاعي للدى طلاب الاراسـات العليـا في كليـة التربية، فإنه يمكن إرجاع هذه النتائج إلى: - ميزات ترتبط بمجتمعات التعلم الاستقصسائي عبر الويـب في البحث الحسلي مثل: مرحسة التهيئة الاجتماعية التي تمت في بايـة التعلم، حيـث مناقثــة الأهـداف ومشــاركة التوقعسات والاهتمامات، والتعريف بمجتمع التعلم وكيفية التعلم، وتقديم مقاطع فيديو تعريفية لكل طالب، عرض القواعد والتعليمات الخاصة بـالتعلم في بدايـة التعلم، وضوح معايير التقييم ومواعيد الاســتحقاق، تخصـيص مســاحات لتثـــارك
- وجـود علاقـة ارتباطيـة موجبـة قويـة ودالـة إحصـائيًا بـين الحضـور المعرفي والحضـور الاجتماعي والإنجاز الأكاديمي، ووجود علاقة

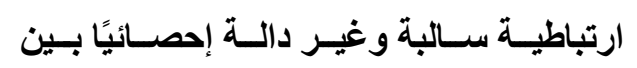
الحضور المعرفي والضغوط الأكاديمية. - وجود علاقة ارتباطية موجبـة ضعيفة وغير

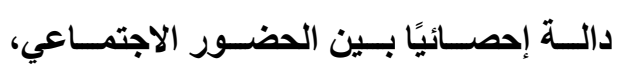
والإنجاز الأكاديمي والضغوط الأكاديمية. - وجود علاقة ارتباطية سـالبة (عكسية) ودالـة

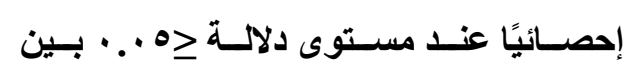
الإنجاز الأكاديمي والضغوط الأكاديمية.

\section{هناقشة وتفسير نتائج البحث.}

سيتم مناقثة نتائج البحث استنادا إلى ما لاحظه الباحث أثناء تجربـة البحث، ومـا أوردته النظريـات

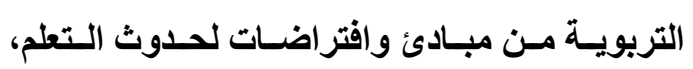

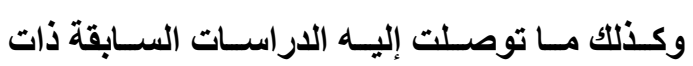
العلاقة.

(1) تفسير النتائج المرتبطة بفاعلية الإستراتيجية القائمة على دمـج إستراتيجيتي التنظيم الذاتي للتعلم ومجتمعات الاستقصساء عبر الويب، في تنمية الحضور المعرفي والاجتماعي، والإنجاز الأكاديمي، ومستوى الضـفوط الأكاديمية للى طلاب الدراسات العليا في كلية التربية. أثــارت نتـائج البحـث إلـى وجـود فـروق دالــة

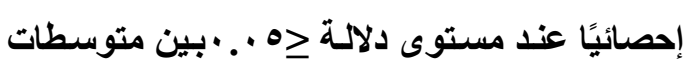
درجات التطبيق القبلي والبعدي لمقاييس الحضور

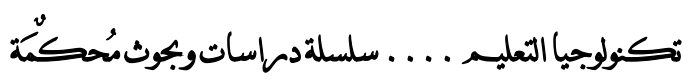


الجمعية المصرية لتكنولوجيا التعليم

ووضـوح مواعيد الاستـققاق، تـوفير وتنويـع

أدوات تقليم الدعم، تقليم تغذية راجعة للطلاب

$$
\text { بشأن أدائهم. }
$$

الاستناد لمبادئ التصميم التعليمي عند تصميم

إستراتيجية التعلم المُنظم ذاتيَّا في مجتمعات

الاستقصـاء عبر الويب مثل استخذام نموذج

للتصـميم التعليمـي وكـنلك الاسـتناد للمعسيير

التصـميمة المرتبطــة بتصــميم الاسـتراتيجية

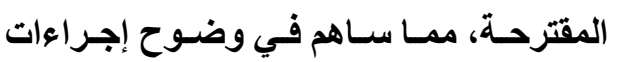

التعليم والتعلم.

الاستناد للمبادئ والآراء النظرية المشتقة من

نظريـات التعلم ذات العلاقة: حيث تتفق نتائج

البحـث الحسالي مـع منطلبـات نظريـة مجتمـع

الاستقصاء عبر الإنترنت، والتي تؤكد على أن

المتعلم بحاجة لثثلاثة أنـواع من الحضور هى الحى

المعرفـي، الاجتمـــي، التّريسـي، وأيضَّــا

نظريـة التعاملات عن بعد أو مـا يُطلق عليها

الفضاء المعرفي والتي ترى أنه لحدوث التعلم

يجـب تـوفير ثلاثـة مكونسات رئيسـية هـى:

التفــاعلات التعليميــة والاجتماعيـة، هيكاــــة

وتنظيم بنيـة الـتعلم، المراقبـة والاسـتقلالية

والتقييم الذاتي، إضافة إلى النظريات المعرفية

والاجتماعية والبنائية والترابطية والتي تلتقي

جميعها في أن التتطم يحدث نتيجـة التثـارك

و التفاعلات التعليمية مع مجتمع التعلم.
وتبـادل الآراء ووجهـات النظـر مثـل لوحسات

النقاش والويكي والمدونـة، تخصيص لقـاءات

افتراضية في بدايـة التعلم وخلالـه، استخدام

محفـزات للمشــاركة مثـل تخصـيص نقــاط،

والدعوة للمشاركة وتعزيز المبادأة والرد على

تعليقـات الآخـرين، اسـتــعاء الأحــاث وربـط

الـتعلم بـالخبرة السـابقة، حـث الطـلاب على

تطــوير مســاحات الـتـعلم الخاصـة بهـم مثـلـل

المــدونات والـــويكي والمنتـــيات، تنويـــع

المحفز ات مثل طلب عـروض وأوراق عمـل

وملخصــات مـن الطـلاب، حـث الطـلاب على

إنشــاء خـرائط مفــاهيم لموضـوعات الـتعلم،

تحديـد محساور النقـاش ممـا سـاهم في تركيز

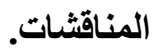

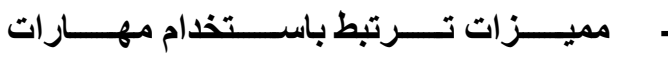

وإسـتراتيجيات التنظيم الـذاتي للـتعلم مثـل:

تخصيص مساحات لتثارك التوقعات وتخطيط

الأهـاف التعليميـة، التعريـف بمجتمـع التـعلم

الاستقصسائي ممـا سـاهم في إدراك المتعلمين

لطبيعـة بيئـة الـتـعلم، تـوفير فـرص التأمسل

والتقيبم الذاتي من خـلال تخصيص مسـاحات

فردية للتعلم وطلب ملخصـات وتقارير، إطلاع

الطلاب على مصسادر إضـافية للتعلم، الاستفادة

مـن المخططــات وخـرائط المفــاهيم، تــدوين

الملاحظــات أثتـــاء الــتعلم، جدولــة المهـــام 
الجمعية المصرية لتكنولوجيا التعليم

تحقيق الأهداف التي تلبي تلك المعايير، تنوع وجهات النظر وتبـادل الآراء سـاهم في زيـادة الثروة المعرفيـة، تقديم التقـارير والملخصـات وخرائط المفاهيم وتدوين الملاحظات ساهم في زيادة الفهز.

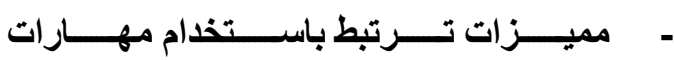
وإسـتراتيجيات التظظيم الــاتي للـتطلم مثـل: استخدام الطلاب لإسـتراتيجية تحليل وتنظيم المهام التعليمية ساهم في زيادة إدراك الطلاب للتعلم، التلخيص والتقيـيم الـذاتي سـاهم في زيــادة الفهــم، تنويــع أدوات طلـب الـــــمع والحصـول على التغذيـة الراجعـة، مشــاركة المتعلم في تحديد أهدافه وتصميم معايير تقييم الأداء ســاهم فـي زيـادة الانخـراط فـي الـتعلم وبالتالي زيادة معدلا الأداء. - إتباع خطوات ومراحل منهجية منظمـة تستند

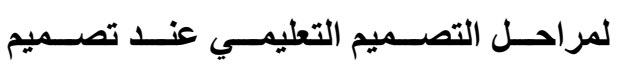
الإستر اتيجية القائمـة على دمـج إسـتراتيجيتي التنظيم الذاتي للتعلم ومجتمعـات الاستقصـاء عبر الويب في تحسين الإنجاز الأكاديمي لدى

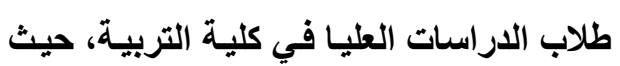
اثتملت تلكك الإستراتيجية على مراحل التهيئة واسـتــعاء الخبـرات الســابقة وتقــيم الـتـلم

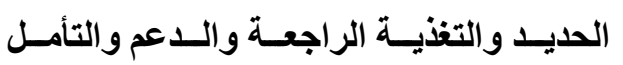

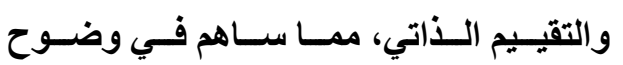

وتتفق هذه النتائج مـع مـا توصلت إليهل نتائج

Cعض الدراسات Akyol \& Garrison, 2008; Kumi-Yeboah et al., 2017; Popescu \& Badea, 2020; Hatmanto \& Pratolo, (2020، وتتفق أيضًا مـع نتـائج دراسـة كـو وكـو Cho and Cho (2017) Doo and Bonk (2020) وجـود تـأثير إيجـابي لإسـتراتيجيات التنظيم الـاتي للتعلم على الحضور المعرفي، كمـا تتفق أيضًا مـع Basdogan نتـائج دراسـة باســوجان (2015) Arka et al. ودراسـة أركـا وزملائسه (2020) واللتـان أكدتا وجـود تـأثير إيجـابي للتنظيم الـذاتي للتعلم على الحضور الاجتماعي. وفيما يتطلق بنتائج الفرض الثانى والذي تم قبوليه، حيـث أثــارت النتـائج إلـى فاعليــة الإسـتراتيجية القائمة على دمج إستراتيجيتي التنظيم الذاتي للتعلم ومجتمعـات الاستقصـاء عبـر الويـب فـي تحسـين الإنجـاز الأكـاديمي للدى طـلاب الدراسـات العليـا في كلية التربية، فإنه يمكن إرجاع هذه النتائج إلى: - ميزات ترتبط بمجتمعات التعلم الاستقصسائي عبـر الويـب في البحـث الحسالي مثـل: تنفيـذ

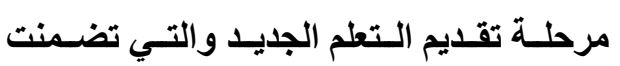
التقصــي والمناقثــات واســخلاص النتـائج، وصـول المتعلمسين لمجموعـة متنوعـة مسن المصـادر والروابط، درايـة المتعلمين بمعايير التقيـيم وبالتـالي تركيز الجهـ والوقـت نحـو

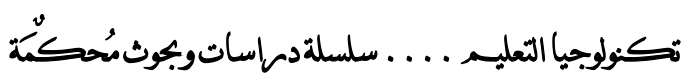


ويالنسـبة لنتـائج الفرض الثالث و الذي تـم قبولـه، حيـث أثــارت النتـائج إلسى فاعليـة الإســتراتيجية القائمة على دمج إستراتيجيتي التنظيم الذاتي للتعلم ومجتمعـات الاستقصـاء عبـر الويـب فـي تحسـين مهارات التعامل مع الضغوط الأكاديمية لدى طلاب الاراسات العليا في كلية التربية، فإنها يمكن إرجاع هذه النتائج إلى: - ميزات تتتلق بخصـائص وطبيعـة مجتمعـات الاستقصـاء عبـر الويـب، حيـث تـم التعريـف

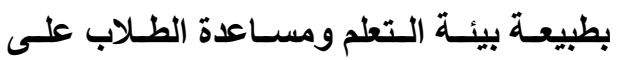
إدرالك سياق التعلم، مما قلل التخوف من التعلم في بيئـات التعلم عبر الويب، توفير تطبيقات التواصل المتنوعة وتعزيز التشـارك والتفاعل مع الآخرين ممـا قلل من الخوف من التعامل مـع الآخرين، هيكلة وتنظيم المهـام التعليميـة ســاهم فـي تبسـيط التعلم وعدم وجـود تعقيــ وتقليـل العـبـ المعرفــي، جدولــة المهـــام التعليميـة سـاعد على تنظيم الـتعلم وتنظيم

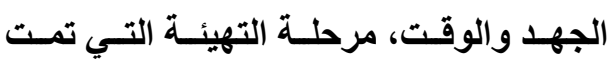

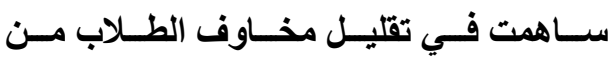
الاختبارات عبر الإنترنت.

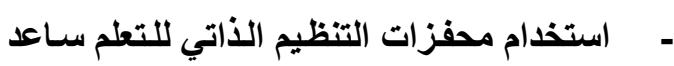
على زيـادة الفاعليـة والكفاعة الأتيـة للطلاب في التعامـل مـع مجتمـع التعلم، كمـا أن جدولـة المهـام سـاعدت على تنظيم الجهود، وتنـوع أدوات طلـب الــــم ومصــادر الـتـعلم وتقـــيم
الإجراءات والتركيز نحو تحقيق أهداف التعلم

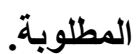
- الأسسس والمبـادئ التـي أستتد عليهـا البحث، والمســتمدة مـن نظريــات الـتـعلم المعرفيــة ونظريـة العبء المعرفي والنظريـة الترابطيـة

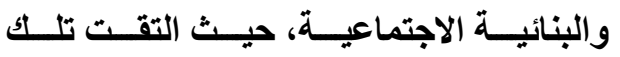
النظريـات فـي أن الأداء والإنجـاز الأكـاديمي يتحقـق بمسـتوى مرتفـع فــي حسال تـوفرت الفرص الكافية للمتعلمين لممارسة الاستقصاء والبحـث وتنــوع المصــادر والـــعم، وتبــادل الآراء ووجهات النظر، وتقديم أنشطة تعتمد المراجعــة والتلخــيص وتقـــيم مخططـــات

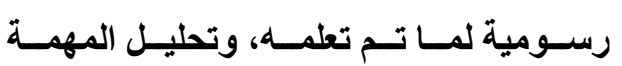
التعليمية وهيكلتها. وتتفق هذه النتائج مـع مـا توصلت إليها نتائج دMiller et al. دراسـة ميلر وزملائهـ (2020) Rohimin et al. ودراسـة روحيمسان وزملائهـ Herayanti ودراسة هرياتتي وزملانـهـ (2020) al. (2020) مقبولــة لمجتمعـات الاستقصــاء عبــر الويـبـ فـي تحسين الأداء الأكساديمي، وأيضًا مـع نتـائج دراسـة Broadbent and Poon بردودبنت ويـون (2015)، وتختلف نتائج البحث الحسالي مـع نتـائج Kizilcec et al, (2017) دراسـة كيزلك وزملائهـ التي أثشارت لعدم وجود تأثير إيجابي للتنظيم الذاتي للتعلم على الأداء الأكاديمي. 
الجمعية المصرية لتكنولوجيا التعليم

وتتفق هذه النتائج مـع مـا توصلت إليسه نتـائج

Mcclelland et al. دراسـة ماكللانــ وزملائهـه

Fuent et (2018)، ودراسة دو لا فونت وزملائه

(اللتين أشارتا لوجود فاعلية لاستخدام ،al. (2020)

إستراتيجيات التظظيم الذاتي للتعلم في زيـادة الفعالية والكفاءة الذاتية و الكفاءة في التعامل مـع مجتمعات التعلم عبر الويب وتنظيم الوقت والجهذ، بمـا يسهرج في تقليل الضـغوط الأكاديمية، وأيضًا دراسـة ياتدرا وآخرون (2021) .Yandra et al. ووفقًَا لنتائج الفرض الرابـع والذي تم قبولـه،

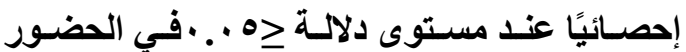
المعرفــي والاجتمـــاعي، بــين الطــلاب مرتفعـي ومنخفضي التظيم الذاتي للتعلم، فإنها يمكن إرجاع هذه النتائج إلى الاهتمام بالمشاركة في بنـاء التعلم، وإتاحسة الفرصـة لكل طالب لإنثــاء مســاحة التعلم الخاصة به، وتوفير الدعم الللازم للوصول للمصسادر التعليمية، والمشاركة في تخطيط الأهداف وتصميم معايير تقييم الأداء، وكذلك المشـاركة في الأنشطة والتفاعلات الاجتماعية، و إدراك سياق التعلم بشكل مناسـب، ونتثـق هـذه النتيجـة مسع نتـائج دراسـة باسـدوجان (2015) Basdogan ودراسـة وانـج وزملائه (2020) (Wong et al. اللتين أكدتا على أن الطلاب ذوى مستويات التظظيم الذاتي المرتفعـة ينخرطون في التعلم ويحققون معدلات إنجاز أعلى. حيـث توصـلت نتـائج البحـث لوجـود فـروق دالـة

الــــم الــلازم للوصـول للمعلومــات المطلوبـة سـاهم في تقليل مستوى الضـغوط الأكاديميـة، مشـاركة الطـلاب في تخطيط أهـاف الـتعلم وتحديد معايير التقييم ساهم في زيادة مستوى التحفيـز والدافعيـة للـتـطم و الســعي لتحقيـق

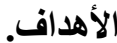
إتبـاع خطوات ومراحل منهجيـة منظمـة عنــ تنفيـذ إســتراتيجية الـتـطم المُـنظم ذاتيَّا فـي مجتمعسات الاستقصــاء عبـر الويـب والتــي اشـتملت على مرحلـة التفكيـر والإعـداد أو التهيـــة، ومرحلــة الأداء، ومرحلــة التقبــيم الذاتي، وهى مراحل تتفق في طبيعتها مـع إجـراءات حدوث الـتعلم، حيـث سـاهمت تلــك الإجراءات في تسلسل عمليات التعلم ووضوح الإجـراءات و التقليـلـل مـن الأعبــاء المعرفيـة الخارجية. - الأسس والمبـادئ التي أستتند عليها البحث، والمســتمدة مسن نظريــة العـبء المعرفـي، ونظرية التعاملات عن بعد والنظريـة المعرفية والبنائية الاجتماعية والتي اتفقت جميعها على مبدأ أنهـ يمكن تقليل الضـوط الأكاديميـة مـن خـلال تقليـل عوامـل التثـتت وزيـادة التركيز وتنظيم وهيكلـة المهـام وجـدولتها ووضـوح تعليمات وقواعد التفاعل ومعايير التقييم، وهذا ما ساهمت في تعزيزه الإستراتيجية المقترحة في البحث الحالي. 
الجمعية المصرية لتكنولوجيا التعليم

المتعلمين ذوي مستويات التظظيم الذاتي المرتفعـة يحققون أداء أعلى وإنجاز أكاديمي أفضل. ووفقًا لنتائج الفرض السـادس و الذي تم قبوليه، حيث أثـارت النتـائج إلى وجـود فروق ذات دلاهـة إحصـائيًا عنـــ مسـتوى دلالــة >0 . . .فـي مسـتوى الضغوط الأكاديمية بين الطلاب مرتفعي ومنغفضي التظظيم الذاتي للتعلم، فإنه يمكن إرجاع هذه النتائج إلى أن مرحلة التهيئة التي تمت سـاهمت في زيـادة الانخراط في التعلم، مما ترتب عليه شعور بالانتمـاء لمجتمـع التعلم وعدم الخـوف مـن التفاعل مـع بيئـة التعلم، كما أن محفزات التظظيم الذاتي للتعلم التي تم تقـــيمها ســـاهمت فـــ تقليـل العـبـ المعرفـي، ومساعدة الطلاب على تنظيم جهودهم وإدارة وقتهم في التعلم، كمـا أن وضوح التعليمـات ومعايير تقييم الأداء سـاهم في وضسوح مستوى الأداء المطلـوب، إضافة إلى أن تنظيم وتحليل المهام واستدعاء التعلم

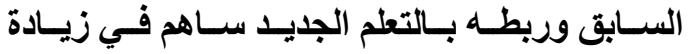
الفعاليـة الذاتيـة، كمــا أن الطـلاب ذوي المسـتويات المرتفعــة مـــن التنظـــيم الـــذاتي يســـتخدمون إسـتراتيجيات التنظيم الذاتي بمستوى أعلى، ممـا يسـاعدهم عـــ إدراك سـياق الـتـعلم، والوصـــول بسهولة لمصادر التعلم، والتعامل مـع الآخرين دون خوف، ويمكن تفسير هذه النتائج في ضوء مضامين النظرية البنائية الاجتماعية ونظرية العبء المعرفي حيـث مشــاركة المـتعلم بفاعليـة فــي بنــاء تعلمـهـ وشـعورة بالمســؤولية تجـاه تعلمسه، وعـدم وجـود
وفيمـا يرتبط بنتائج الفرض الخـامس والذي تث قبوله، حيث توصلت نتائج البحث إلى وجود فروق

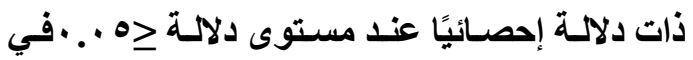
الإنجـاز الأكـاديمي بين الطلاب مرتفعي ومنففضي التظظيم الذاتي للتعلم، فإنه يمكن إرجاع هذه النتائج إلـى تنـوع مصــادر التعلم التـي تـوفرت في مجتمع الاستقصاء عبر الويب، مشاركة الطلاب في تخطيط

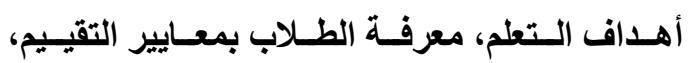
وضوح مواعيد الاستحقاق وجدولـة المهام، تنـوع فرص المشـاركة في إنثـاء مسـاحات للتعلم، توفير التغذية الراجعة، إتاحة فرص التأمل والتقييم الذاتي من خلال المراجعة والتلخيص وتدوين الملاحظات وكتابـة التقـارير، كمـا يمكن تفسير تلك النتائج في ضوء المبادئ المشتقة من نظريـات التعلم البنائية والترابطية حيث أكلتا على أن التعلم يحدث من خلال مشاركة المتعلم في بناء تعلمه، وكذلك نظرية العبء المعرفي التي ترى أن تنظيم بنيـة المهام التعليميـة وهيكلتهــا وإدراك بيئـة الـتعلم يسـهمان فـي تقليـل العبء المعرفي الخـارجي، كمـا أن توفر محفزات التتظيم الـذاتي يـؤدي إلسى زيـادة الدافعيـة للإنجـاز والاستعداد للتعلم والاستمرارية، وتتثق هذه النتيجة مـع مـا توصـلت إليـه دراسـة نصسير ومطلب زاده Nasseri and Motallebzadeh (2016) Altay and ودراسـة آلتـي وسـركالوجل Zheng ودراسـة شينج Saracaloglu (2017)

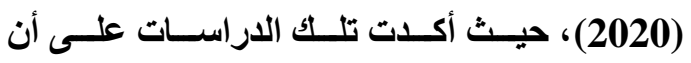


الجمعية المصرية لتكنولوجيا التهليم

النتائج لوجود ارتباط موجب قوي دال إحصـائيًا عند مستوى دلالة \0 • . • بين بين الإستراتيجية القائمة علـى دمــج إســتراتيجية التظظـيم الــذاتي للـتـعم ومجتمعسات الاستقصــاء عبـر الويسب، والحضـور المعرفي، وأن أكثر إســراتيجيات التنظيم الـذاتي للتعلم ارتباطًا وإسـهامًا في تفسير تحسن الحضور المعرفي هما (إدراك مجتمع الاستقصاء عبر الويب، تنظيم وتحليـل المهام والأنشطة الاستقصـائية عبر

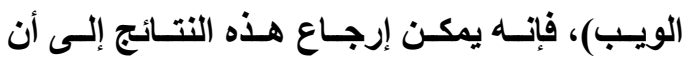
إسـتراتيجيات التنظـيم الـذاتي سـاهمت في تـلـريب الطلاب على تخطيط الأهداف، وبالتالي معرفة مـاذا يجب عليهم أن يتعلموه، وكذلك وضوح التعليمـات

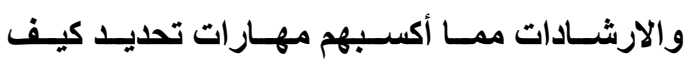
سـيتعلمون، كمـا أن إسـتراتيجيات التتظـيم الـذاتي أكسبت الطلاب مهارات إدراك مجتمـع التعلم وكيفيـة الوصـول للمعلومـات مـن مصــادرها المتنوعـة، إلى جانـب معرفـة الطـلاب لمعـاييز التقيـيم منــذ البدايـة ساهم في التحفيز الذاتي لهم، وكنلك توفر التغذيـة الراجعة، وتتفق هذه النتـائج مـع مـا توصـلت إليـه ، Cho and Cho (2017) براسـة كـو وكـو (2017) ودراسـة دو وبونـك (2020) Doo and Bonk كما أشسارت النتـائج لوجود ارتبـاط ضـعيف غير دال إحصائيًا بين مستوى استخدام إستراتيجيات التتظيم الذاتي والحضـور الاجتمـاعي، ويمكن إرجـاع هذه النتيجة إلى تركيز اهتمـام الطلاب على البحث عن المعلومات والتعرف على بيئة التعلم وتثفيذ المهام
عوامل تشتيت مما أسـهم في تقليل العبء المعرفي الخـارجي الــي يـؤثر علـى الأداء ممــا يزيــــــن الضـفوط الأكاديميـة، وتتفق هذه النتـائج مـع نتـائج ، Zimmerman راســة زيمرمسـان (2010) ودراسـة تثـنج (2020) 2heng، ودراسـة دا لا فينت (2020) في أن الطلاب ذوى المستويات المرتفعة من التظيم الأتي لايهم القدرة على مواجهة الضغوط الأكاديمية بكفاءة. (Y) تفسير النتـائج المتعلقــة بالعلاقـة الارتباطيـة بـين الإســتراتيجية المقترحسـة، والحضــور المعرفـي والاجتمــاعي، والإنجـاز الأكـاديمي، ومسـتوى الضـغوط الأكاديميــة لـــى طـلاب الاراسات العليا في كلية التربية. أشارت نتائج البحث إلى وجود علاقة ارتباطية موجبة دالة إحصائيًا عند مستوى دلاكة \ه . . • بين الإستراتيجية القائمة على دمـج إستراتيجية التنظيم الذاتي للتعلم ومجتمعسات الاستقصساء عبر الويب، والحضـور المعرفي والإنجـاز الأكساديمي، في حين أشـارت النتائج لوجود علاقة ارتباطية قويـة عكسية ودالـة إحصـائيًا مـع الضـغوط الأكاديميـة، ولـم تُحقق العلاقـة الارتباطيـة مـع الحضـور الاجتمـاعي دلالـة إحصـائية، ويمكن تفسير هذه النتـائج على النحو

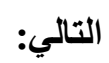

بالنسبة لنتائج الفرض السـابع والذي تم قبولـه فيمسا يتعلق بمكون الحضـور المعرفى ورفضـه فيما يتعلـق بمكون الحضـور الاجتمـاعي، حيـث أشـارث

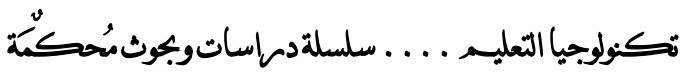


تحديدها، وضوح معايير التقييم، وضوح التعليمـات

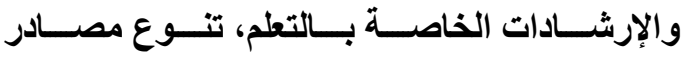
المعلومــات، الجدولــة الزمنيــة للمهــام، اســتخدام محفزات التظيم الأتي للتعلم مثل التلخيص وتدوين الملاحظــات ورسـم خـر ائط مفــــيم، وتتفـق هـــه النتيجــة مـــع نتــائج دراســـة بردوبنـــت ويسـون Broadbent and Poon (2015) مع النتيجة التي توصلت لها دراسة كيزلاك وزملائسه Kizilcec et al. (2017) ، حيث توصلت إلى إن إستراتيجيات التنظيم الذاتي للتعلم تؤثر سلبًا على إلى أداء المتعلم وتحصيله الاراسي. وبالنسبة لنتائج الفرض التاسع و الأي تم قبوليه، حيث أشارت النتائج لوجود ارتباط سـالب (عكسي) قوي دال إحصـائيًا عند مستوى دلالـة >0 . . • بين الإستراتيجية القائمة على دمهج إستراتيجية التنظيم الذاتي للتعلم ومجتمعـات الاستقصـاء عبر الويب، إنبـ والضغوط الأكاديمية، وأن أكثر إستراتيجيات التظظيم الأتي للتعلم ارتباطًا و إسهامًا في تفسير زيادة معدل الإنجاز الأكاديمي هى (تخطيط الأهداف والتوقعات، إدراك مجتمع الاستقصـاء عبر الويب، يليهم تنظيم وتحليل المهام والأنثطة الاستقصائية عبر الويب)، فإنـهـ يمكـن إرجـاع هـذه النتيجـة إلسى أن اسـتخدام إسـتراتيجيات التنظيم الـذاتي للتعلم سـاهمت في: زيــادة الفعاليـة الذاتيـة للطـلاب، تحسـين كفــاعتهم الأتيـة في التعامـل مـع مجتمـع التعلم الاستقصـائي عبر الويب والتطبيقـات المتاحة فيه، إدارة وتنظيم
والأنشطة المطلوبة في التوقيت المحدد لها، وهذا ما يُفسر سبب التأثير السلبي لاستخدام استراتيجيات (تخطيط الأهداف والتوقعات، التأمل والتقييم الذاتي) حيث غلب على الطلاب طابع العمل الفردي أكثر من التعلم الاجتماعي، وتتفق نتائج البحث الحالي مـع مـا Kizilcec et أشسارت لله دراسـة كيزلاك وزملائهـ al. (2017 ، في حين تختلف مـع مـا توصلت لله دراسـة باسدوجان (2015) Basdogan ودراسـة أركـا وزملائهـ (2020) Arka et al. ويمكن القـول أيضًّـا أن صــر حجـم العيـــة ـ النــاتج عـن تصـنيف الطـلاب إلـى نســبة (ه \% \%) للفئـة ذات مستوى التنظيم الذاتي المرتفع، ونسبة (0Y\%\%) للفئة ذات مستوى التنظيم الأتي المنخفض- يُعد من محددات الار اسة وتعميم تلك النتيجة. ووفقَّا لنتائج الفرض الثامن والذي تم قبولـه، حيث أشارت النتائج لوجود ارتباط موجب قوي دال

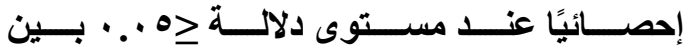
الإستراتيجية القائمة على دمهج إستراتيجية التنظيم الـذاتي للتعلم ومجتمعسات الاستقصـاء عبـر الويـب والإنجاز الأكاديمي، وأن أكثر إستراتيجيات التنظيم الأتي للتعلم ارتباطًا وإسهامًا في تفسير زيادة معدل الإنجـاز الأكـاديمي هـ (إدراك مجتمـع الاستقصــاء عبـر الويـبـ، تنظـيم وتحليـل المهــام والأنثـــة الاستقصــائية عبـر الويـب، يــــهم طلـب الـــــم

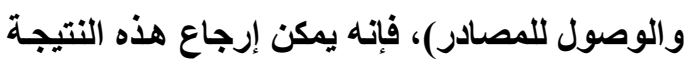
إلىى: وضسوح أهداف التعلم ومشساركة الطلاب في 
الجمعية المصرية لتكنـولوجيا التعليم

وزملانـه Gutierrez-Santiuste et al. (2015) وبــين الحضــــور المعرفــي والإنجـــاز الأكـاديمي، واتفقت هذه النتيجة مـع نتيجة دراسـة Kozan and Richardson (2014) Muljana and Luo (2019) النتائج لوجود ارتبـاط سـالب (عكسي) قوي ودال

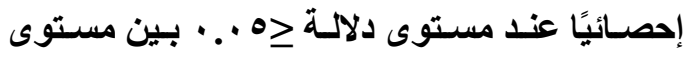
الحضور المعرفي والضغوط الأكاديمية، وتتفق هذه النتيجة مع نتيجة دراسة Kozan (2016) ونتيجة دراسة (2016) Perfect et al. ، وبين الضغوط الأكاديمية والإنجاز الأكاديمي، وتتفق هذه النتيجة مع نتيجة دراسة (2020) Pascoe et al. دراسة (Shorer and Leibovich (2020) وتوصلت النتائج أيضًا لوجود ارتباط ضعيف وغير دال إحصـائيًا بـين الحضـور الاجتمـاعي والإنجـاز الأكاديمية، وتختلف هذه النتائج مع مـا توصلت إليه (Horzum, 2017; Yildirim et al., دراسات .2017; Costley, 2019)

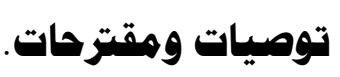

$$
\text { أ- توصيات البحث: }
$$

في ضوء نتائج البحث الحسالي يمكن التوصية بمـا يلي:

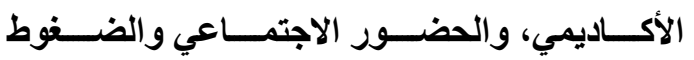

الوقتـ والجهود، تحليـل المهام التعليميـة وتحديد مكوناتها الفرعية، المثـاركة في تخطيط الأهداف و التوقعات بمـا يسهم في تنمية الإحساس بمجتمع التطلم والانخراط في التطلم، تنفيذ مرحلة التهيئة، وتنويع أدوات التواصل مع الآخرين وتحديد معايير المشاركة وتقييم الأداع، حيث أدت كل هذه العوامل إلى تخفيف الضـغوط الأكاديميـة و إكسـاب الطـلاب مهارات التعامل معها، وتتفق هذه النتيجة مع نتيجة دراسة زينير وزملائه (2014) (Zenner et al.

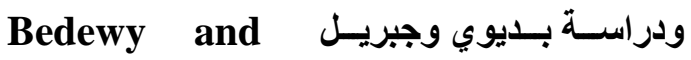
Gabriel ودراسـة كونهوفن ودورجي Kaunhoven and Dorgee (2017) أسـفرت نتائجها عـن أن المتطمسين ذوي مسـتوى التنظيم الذاتي المرتفع هم أكثر قدرة على التعامل مع الضغوط الأكاديمية و التقليل من آثار ها.

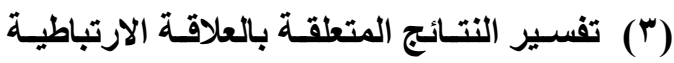
بين الحضور المعرفي والاجتماعي، والإنجاز الأكاديمي، ومستوى الضـوط الأكاديمية للى طلاب الدراسات العليا في كلية التربية.

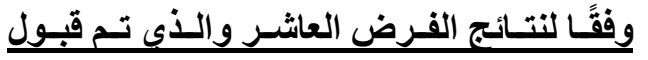
نتانجه جزئيًا، حيث أثشارت النتائج لوجود ارتباط

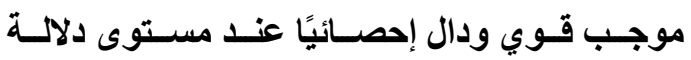
ج • . • بين مستوى الحضور المعرفي والحضور الاجتمـاعي، وتتفق هذه النتيجة مـع نتائج دراسـة Kozan and Richardson ودراســة جيـوتيرز 
الجمعية المصرية لتكنولوجيا التعليم

- الاسـتفادة مسن المراحل التي تـم تحديـدها في

البحث لإستراتيجي التعلم المنظم ذاتيَّا والتعلم

القائم على الاستقصاء عبر الويب.

ب- مقترحات بحثية.

في ضوع ما تم التوصل إليه وحدود الاراسـة يمكن

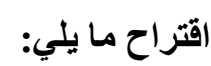

- بحـث العلاقة بـين مسـتويات التنظيم الـذاتي (مرتفعـة، متوســة، ومنخفضـة) وأسـلوب التعلم لـى طلاب المرحلة الجامعة، وتأثيرهـا

$$
\text { على جوانب تعليمية أخرى. }
$$

- بحـث التفاعـل بـين نمـط الاستقصـاء (حـر،

موجه، معتدل) ومستوى التتظيم الذاتي للتعلم (مرتفع، متوسط، منخفض) على الانخراط في

التعلم وبقاء أثره لاى طلاب المرحلة الابتدائية

$$
\text { أو الإعدادية. }
$$

- اســخدام تكنولوجيـا تحلـيلات الـتعلم للتتبـؤ

بإســتراتيجيات التنظـيم الــذاتي المسـتخدمة

للتعامـلـل مــع مواجهـــة الضـــوط الأكاديميــة

$$
\text { المصاحبة للتعلم عبر الإنترنت. }
$$

- تأثير اختلاف التظيم (الذاتي، الخارجي) للتعلم

على نـوع إسـتراتيجيات مواجهـة الضـغوط

الأكاديميـة (موجهـة نحـو المشــاعر، موجهـة

نحـو المهـــة) و الكفــاءة الذاتيـة لـدى طـلاب

المرحلة الجامعية.
- الاهتمام بتنمية مهارات استخدام إستراتيجيات

التظظيم الأاتي لاى الطلاب للتعامل بكفـاءة مـع

$$
\text { بيئات التعلم عبر الإنترنت. }
$$

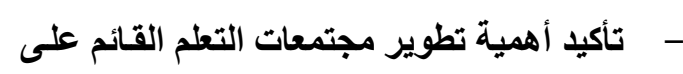

الاستقصـاء وتـوفير الأدلـة الإرشـادية اللازمـة

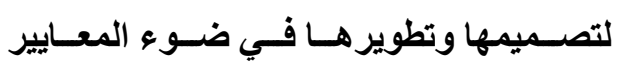
التصميمة التي توصل لها البحث الحالي.

تأكيـــ أهميـة التوعيـة بإسـتر اتيجيات تعزيـز الحضـور المعرفـي والاجتمــاعي والتدريسـي التي وردت في البحث الحالي، وأهمية التدريب عليها وتوظيفها في التعلم عبر الإنترنت.

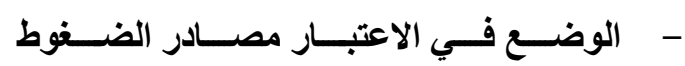
الأكاديميـة التـي تـم التوصـل إليهـا في البحث الحسالي، وتـدريب الطـلاب على إسـتراتيجيات التعامـل مـــع الضــوط الأكاديميـة المصــاحبة للتعلم القائم على الإنترنت.

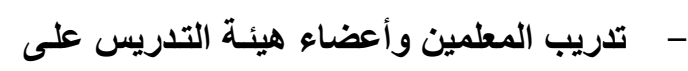
استخدام إسـتراتيجية التعلم المسنظم ذاتيـا في مجتمعات التعلم الاستقصسائي عبر الويب التي تم التوصل إليها في البحث الحالي. - الاستفادة من المقاييس التي تم تصميمها في البحث الحالي وهي مقياس الحضور المعرفي والاجتمــاعي والتدريسـي، مقيــاس التنظـيم الذاتي للتعلم، مقيـاس الضـوط الأكاديمية في بيئات التعلم عبر الويب. 
الجمعية المصرية لتكنولوهيا التعليم

- دراسة العلاقة بين إستراتيجيات التعلم المنظم

ذاتيًا ومستوى المعالجـة المعرفيـة لـى طلاب

الصف الأول الثانوي في مادة الفيزياء.

- تكرار إجراءات تثفيذ الإستراتيجية المقترحة

في البحث الحسالي في ضوء متغيرات أخرى

مثل: حجم عينـة أكبر، مرحلة عمريـة أصسر،

فترة زمنيـة أطـول للتجربـة ــربمـا تـؤثر تلك

المتغيرات في التتائج التي سيتم التوصل إليها. 
الجمعية المصرية لتكنولوجيا التعليم

\section{A proposed strategy based on a combination of self-regulation learning}

strategy and online inquiry communities, and its effect on cognitive and social presences, academic achievement and dealing with academic pressures for graduate students in faculty of education.

Said abdelmawgoud El-aasar.

Assistant Professor of instructional Technology and Computer

Faculty of Specific Education, Menoufia Unversity

Faculty of Education, Najran Unversity

\section{Abstract.}

This research aims to conduct the effect of a proposed strategy based on a combination of self-regulation learning strategy and online inquiry communities, on cognitive and social presences, academic achievement and dealing with academic pressures for graduate students in faculty of education. Where the developmental research method was used, and the strategy was applied to (21) Student, preparing a list of design criteria, and Scales for: Cognitive, Social and teaching Presence, self-regulation learning, academic stress. Then using statistical treatments: descriptive statistics, t-test, Mann Whitney test, correlation coefficients. The results reached to the effectiveness of a strategy Self-organized learning in OCI in developing cognitive and social presence, academic achievement, and reducing academic stress, there is a statistical significance for the difference between high and low self-regulation in cognitive and social presence, academic achievement, and academic stress in favor of the high level. There is a positive correlation between the self-regulation strategies, cognitive presence, academic achievement, negative correlation with academic stress. There is a positive correlation between cognitive presence, social presence, and academic achievement, and negative correlation between academic achievement and academic stress

Key Words:

Self-Regulated Learning, Online Community of Inquiry, Cognitive Presence, Social Presence, Academic pressures, and Learning Achievement. 
الجمعية المصرية لتكنـولوجيا التنعليم

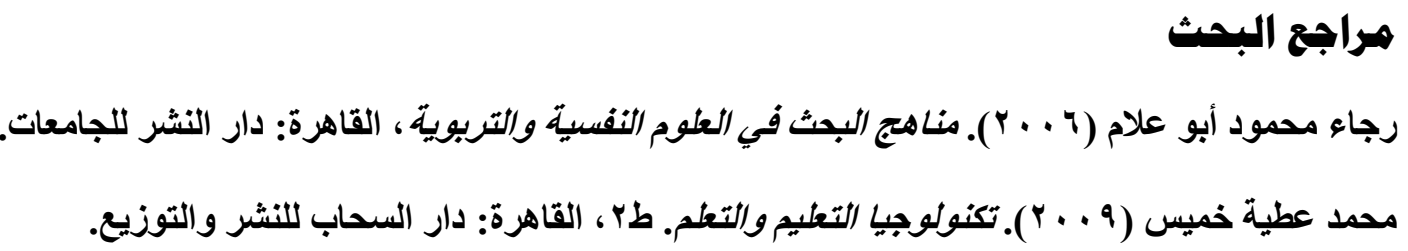

Abouammoh, N., Irfan, F., \& AlFaris, E. (2020). Stress coping strategies among medical students and trainees in Saudi Arabia: a qualitative study. $B M C$ medical education, 20, 1-8.

Akyol, Z., \& Garrison, D. (2008). The Development of a Community of Inquiry over Time in an Online Course: Understanding the Progression and Integration of Social, Cognitive and Teaching Presence.Journal of asynchronous learning networks, 12, 3-22.

Altay, B., \& Saracaloglu, A. S. (2017). Investigation on the Relationship among Language Learning Strategies, Critical Thinking and Self-Regulation Skills in Learning English. Novita's-ROYAL (Research on Youth and Language), 11(1), 1-26.

Anderson, T. (2016). Theories for learning with emerging technologies. Emergence and innovation in digital learning: Foundations and applications, 1, 35-50.

Anderson, T. (2017). How communities of inquiry drive teaching and learning in the digital age. North Contact, 1-16.

Araka, E., Maina, E., Gitonga, R., \& Oboko, R. (2020). Research trends in measurement and intervention tools for self-regulated learning for e-learning environments-systematic review (2008-2018). Research and Practice in Technology Enhanced Learning, 15(1), 1-21.

Baldwin, S. J., \& Ching, Y. H. (2019). An online course design checklist: development and users' perceptions. Journal of Computing in Higher Education, 31(1), 156-172. 
Barnard, L., Lan, W. Y., To, Y. M., Paton, V. O., \& Lai, S. L. (2009). Measuring self-regulation in online and blended learning environments. The internet and higher education, 12(1), 1-6.

Başdoğan, M. (2015). Community of inquiry framework as a predictor of selfregulated learning in an online certificate program (Master's thesis).

Bedewy, D., \& Gabriel, A. (2015). Examining perceptions of academic stress and its sources among university students: The Perception of Academic Stress Scale. Health psychology open, 2(2), 2055102915596714.

Bloomberg, L. D. (2020). Developing a Learning Community through an Online University's Community Engagement Platform: An Analysis of the Experiences of Students and Faculty. International Journal of Online Graduate Education, 3(1).

Broadbent, J., \& Poon, W. L. (2015). Self-regulated learning strategies \& academic achievement in online higher education learning environments: A systematic review. The Internet and Higher Education, 27, 1-13.

Carter Jr, R. A., Rice, M., Yang, S., \& Jackson, H. A. (2020). Self-regulated learning in online learning environments: strategies for remote learning. Information and Learning Sciences.

Castle Jr, T. D. (2014). The impact of cooperative learning on the development of need for cognition among first-year college students.

Chawla, K., \& Sachdeva, V. (2018). Domains of stress and coping strategies used by 1st year medical students. National Journal of Physiology, Pharmacy and Pharmacology, 8(3), 366-369. 
الجمعية المصرية لتكنـولوجيا التنعليم

Chen, B., Denoyelles, A., Patton, K., \& Zydney, J. (2017). Creating a community of inquiry in large-enrollment online courses: An exploratory study on the effect of protocols within online discussions. Online Learning, 21(1), 165-188.

Cho, M. H., Kim, Y., \& Choi, D. (2017). The effect of self-regulated learning on college students' perceptions of community of inquiry and affective outcomes in online learning. The Internet and Higher Education, 34, 10-17.

Costley, J. (2019). The relationship between social presence and cognitive load. Interactive Technology and Smart Education, 12(2), 172-182.

Costley, J., \& Lange, C. (2016). The Relationship between Social Presence and Critical Thinking: Results from Learner Discourse in an Asynchronous Learning Environment.

Dabbagh, N., \& Kitsantas, A. (2013). Using learning management systems as metacognitive tools to support self-regulation in higher education contexts. In International handbook of metacognition and learning technologies (pp. 197-211). Springer, New York, NY.

De Jong, T., Sotiriou, S., \& Gillet, D. (2014). Innovations in STEM education: The Go-Lab federation of online labs. Smart Learning Environments, 1(1), 1-16.

de la Fuente, J., Amate, J., González-Torres, M. C., Artuch, R., García-Torrecillas, J. M., \& Fadda, S. (2020-a). Effects of levels of self-regulation and regulatory teaching on strategies for coping with academic stress in undergraduate students. Frontiers in psychology, 11, 22 
de la Fuente, J., Fernández-Cabezas, M., Cambil, M., Vera, M. M., GonzálezTorres, M. C., \& Artuch-Garde, R. (2017). Linear relationship between resilience, learning approaches, and coping strategies to predict achievement in undergraduate students. Frontiers in psychology, $8,1039$.

de la Fuente, J., Sander, P., Kauffman, D. F., \& Yilmaz Soylu, M. (2020). Differential Effects of Self-vs. External-Regulation on Learning Approaches, Academic Achievement, and Satisfaction in Undergraduate Students. Frontiers in Psychology, 11, 2678.

Dent, A. L., \& Koenka, A. C. (2016). The relation between self-regulated learning and academic achievement across childhood and adolescence: A metaanalysis. Educational Psychology Review, 28(3), 425-474.

Dignath, C., \& Büttner, G. (2018). Teachers' direct and indirect promotion of selfregulated learning in primary and secondary school mathematics classesinsights from video-based classroom observations and teacher interviews. Metacognition and Learning, 13(2), 127-157.

Dolfen, N., King, B. R., Schwabe, L., Swinnen, S., \& Albouy, G. (2019). Glucocorticoid response to stress induction prior to learning is negatively related to subsequent motor memory consolidation. Neurobiology of learning and memory, 158, 32-41.

Doo, M. Y., \& Bonk, C. J. (2020). The effects of self-efficacy, self-regulation, and social presence on learning engagement in a large university class using flipped Learning. Journal of Computer Assisted Learning, 36(6), 997-1010. 
الجمعية المصرية لتكنولويبيا التعليم

Faleel, S. F., Tam, C. L., Lee, T. H., Har, W. M., \& Foo, Y. C. (2012). Stress, perceived social support, coping capability and depression: A study of local and foreign students in the Malaysian context. International Journal of Psychological and Behavioral Sciences, 6(1), 1-7.

Fiock, H. (2020). Designing a community of inquiry in online courses. The International Review of Research in Open and Distributed Learning, 21(1), 135-153

Flynn, C., Olson, J., \& Reinhardt, M. (2020). Self-regulated learning in online graduate business communication courses: a qualitative inquiry. Business and Professional Communication Quarterly, 83(1), 80-95.

Friskawati, G. F. (2021). Students' Academic Level Stress during Online Learning in Physical Education. JUARA: Jurnal Olahraga, 6(1), 79-87.

Garrison, D. R., Anderson, T., \& Archer, W. (2001). Critical thinking, cognitive presence, and computer conferencing in distance education. American Journal of distance education, 15(1), 7-23.

Garrison, D. R., Anderson, T., \& Archer, W. (2003). A theory of critical inquiry in online distance education. Handbook of distance education, 1, 113-127.

Godwin, L., \& Kaplan, S. (2008). AI version 2.0: new models of appreciative inquiry in the digital age. AI Practitioner, 14(2), 8-13.

Goh, L. H. (2020). The Gathering of the Community of Inquiry in Online Learning. International Journal of Information and Education Technology, 10(7), 494-499. 
Gu, X., Yu, Y., Li, Y., Li, J., Askari, M., \& Samali, B. (2019). Experimental study of semi-active magneto rheological elastomer base isolation system using optimal neuro fuzzy logic control.Mechanical Systems and Signal Processing, 119, 380-398.

Gutierrez-Santiuste, E., Rodríguez-Sabiote, C., \& Gallego-Arrufat, M. (2015). Cognitive presence through social and teaching presence in communities of inquiry: A correlational-predictive study.Australasian Journal of Educational Technology, 31, 349-362.

Hatmanto, E., \& Pratolo, B. (2020). The articulation of the Community of Inquiry Framework in the Online Discussion. International Journal of Psychosocial Rehabilitation, 24(8), 10928-10940.

Heilporn, G., \& Lakhal, S. (2020). Investigating the reliability and validity of the community of inquiry framework: An analysis of categories within each presence. Computers \& Education, 145, 103712.

Herayanti, L., Widodo, W., Susantini, E., \& Gunawan, G. (2020). The effectiveness of blended learning model based on inquiry collaborative tutorial toward students' problem-solving skills in physics. Journal for the Education of Gifted Young Scientists, 8(3), 959-972.

Horzum, M. B. (2017). Interaction, structure, social presence, and satisfaction in online learning. Eurasia Journal of Mathematics, Science and Technology Education, 11(3), 505-512.

Jenaabadi, H., Nastiezaie, N., \& Safarzaie, H. (2017). The relationship of academic burnout and academic stress with academic self-efficacy among graduate students. The Educational Review, 49(3), 65-76. 
الجمعية المصرية لتكنـولوجيا التنعليم

Jimoyiannis, A., \& Roussinos, D. (2017). Students' collaborative patterns in a wikiauthoring project. Journal of Applied Research in Higher Education

Joksimović, S., Gašević, D., Kovanović, V., Riecke, B., \& Hatala, M. (2015). Social presence in online discussions as a process predictor of academic performance. J. Comput. Assist. Learn., 31, 638-654.

Joseph, N., Nallapati, A., Machado, M. X., Nair, V., Matele, S., Muthusamy, N., \& Sinha, A. (2020). Assessment of academic stress and its coping mechanisms among medical undergraduate students in a large Midwestern university. Current Psychology, 1-11.

Karaman, M. A., \& Watson, J. C. (2017). Examining associations among achievement motivation, locus of control, academic stress, and life satisfaction: A comparison of US and international undergraduate students. Personality and Individual Differences, 111, 106-110.

Kaunhoven, R. J., \& Dorjee, D. (2017). How does mindfulness modulate selfregulation in pre-adolescent children? An integrative neurocognitive review. Neuroscience \& Bio behavioral Reviews, 74, 163-184.

Kilis, S., \& Yıldırım, Z. (2018). Investigation of community of inquiry framework regarding self-regulation, metacognition, and motivation. Computers \& Education, 126, 53-64.

Kizilcec, R. F., Pérez-Sanagustín, M., \& Maldonado, J. J. (2017). Self-regulated learning strategies predict learner behavior and goal attainment in Massive Open Online Courses. Computers \& education, 104, 18-33. 
Kozan, K. (2016). The incremental predictive validity of teaching, cognitive and social presence on cognitive load. Internet High. Educ., 31, 11-19.

Kozan, K., \& Richardson, J. C. (2014). Interrelationships between and among social, teaching, and cognitive presence. The Internet and higher education, 21, 68-73.

Kumar, S., \& Ritzhaupt, A. D. (2014). Adapting the community of inquiry survey for an online graduate program: Implications for online programs. $E$ learning and Digital Media, 11(1), 59-71.

Kumi-Yeboah, A. (2018). Designing a cross-cultural collaborative online learning framework for online instructors. Online Learning, 22(4), 181-201

Lee, D., Watson, S. L., \& Watson, W. R. (2020-a). The Relationships between SelfEfficacy, Task Value, and Self-Regulated Learning Strategies in Massive Open Online Courses. International Review of Research in Open and Distributed Learning, 21(1), 23-39.

Lee, R., Hoe Looi, K., Faulkner, M., \& Neale, L. (2020-b). The moderating influence of environment factors in an extended community of inquiry model of e-learning. Asia Pacific Journal of Education, 1-15.

Lee, S. J., \& Huang, K. (2018). Online interactions and social presence in online learning. Journal of Interactive Learning Research, 29(1), 113-128.

Leppink, E. W., Odlaug, B. L., Lust, K., Christenson, G., \& Grant, J. E. (2016). The young and the stressed: Stress, impulse control, and health in college students. The Journal of nervous and mental disease, 204(12), 931-938. 
الجمعية المصرية لتكنولوبيا التعليم

Littlejohn, A., Hood, N., Milligan, C., \& Mustain, P. (2016). Learning in MOOCs: Motivations and self-regulated learning in MOOCs. The Internet and Higher Education, 29, 40-48.

Lodge, J. M., Panadero, E., Broadbent, J., \& de Barba, P. G. (2018). Supporting self-regulated learning with learning analytics. In learning analytics in the classroom (pp. 45-55). Routledge.

Ma, N., Du, L., Zhang, Y. L., Cui, Z. J., \& Ma, R. (2020). The effect of interaction between knowledge map and collaborative learning strategies on teachers' learning performance and self-efficacy of group learning. Interactive Learning Environments, 1-15

Ma, Z., Wang, J., Wang, Q., Kong, L., Wu, Y., \& Yang, H. (2017). Verifying Causal Relationships among the Presences of the Community of Inquiry Framework in the Chinese Context. The International Review of Research in Open and Distributed Learning, 18, 213-230.

MacIntyre, P. D., Gregersen, T., \& Mercer, S. (2020). Language teachers' coping strategies during the Covid-19 conversion to online teaching: Correlations with stress, wellbeing, and negative emotions. System, 94, 102352.

McClelland, M., Geldhof, J., Morrison, F., Gestsdóttir, S., Cameron, C., Bowers, E., ... \& Grammer, J. (2018). Self-regulation. Handbook of life course health development, 275-298.

Miller, M. E., Newton, K., Stover, S., Miller, B., \& Buttolph, J. (2020). Comparing Delivery Methods of an Introductory Nutrition Course Using the Community of Inquiry. Journal of nutrition education and behavior, 52(4), 401-406 
Min, H., \& Nasir, M. K. M. (2020). Self-Regulated Learning in A Massive Open Online Course: A Review of Literature. European Journal of Interactive Multimedia and Education, 1(2), 1-6.

Moos, D. C., \& Bonde, C. (2016). Flipping the classroom: Embedding selfregulated learning prompts in videos. Technology, Knowledge and Learning, 21(2), 225-242.

Muljana, P. S., \& Luo, T. (2019). Factors contributing to student retention in online learning and recommended strategies for improvement: A systematic literature review.Journal of Information Technology Education: Research, 18.

Naseri, S., \& Motallebzadeh, K. (2016). Podcasts: a factor to improve Iranian EFL learner 'self-regulation ability and use of technology. Journal of Educational Technology \& Society, 19(2), 328-339.

Nasir, M. (2020). The Influence of Social Presence on Students' Satisfaction toward Online Course. Open Praxis, 12, 485-493.

Nolan-Grant, C. R. (2019). The Community of Inquiry framework as learning design model: a case study in postgraduate online education. Research in Learning Technology, 27.

Pascoe, M. C., Hetrick, S. E., \& Parker, A. G. (2020). The impact of stress on students in secondary school and higher education. International Journal of Adolescence and Youth, 25(1), 104-112.

Pedaste, M., Mäeots, M., Siiman, L. A., De Jong, T., Van Riesen, S. A., Kamp, E. T., \& Tsourlidaki, E. (2015). Phases of inquiry-based learning: Definitions and the inquiry cycle. Educational research review, 14, 47-61. 
الجمعية المصرية لتكنـولوجيا التنعليم

Perfect, M. M., Turley, M. R., Carlson, J. S., Yohanna, J., \& Saint Gilles, M. P. (2016). School-related outcomes of traumatic event exposure and traumatic stress symptoms in students: A systematic review of research from 1990 to 2015. School Mental Health, 8(1), 7-43.

Pintrich, P. R. (2004). A conceptual framework for assessing motivation and selfregulated learning in college students. Educational psychology review, 16(4), $385-407$.

Popescu, E., \& Badea, G. (2020). Exploring a Community of Inquiry Supported by a social media-Based Learning Environment. Educational Technology \& Society, 23(2), 61-76.

Radeef, A. S., Faisal, G. G., Ali, S. M., \& Ismail, M. K. H. M. (2014). Source of stressors and emotional disturbances among undergraduate science students in Malaysia. International Journal of Medical Research \& Health Sciences, 3(2), 401-410.

Ramdass, D., \& Zimmerman, B. J. (2011). Developing self-regulation skills: The important role of homework. Journal of advanced academics, 22(2), 194-218.

Ramli, N. H., Alavi, M., Mehrinezhad, S. A., \& Ahmadi, A. (2018). Academic stress and self-regulation among university students in Malaysia: Mediator role of mindfulness. Behavioral Sciences, 8(1), 12.

Reddy, K. J., Menon, K. R., \& Thattil, A. (2018). Academic stress and its sources among university students. Biomedical and Pharmacology Journal, 11(1), 531-537. 
Rezaei, E., Nili, M., Fardanesh, H., \& Shahalizadeh, M. (2020). Qualitative Content Analysis of Connectivism Theory and Introducing a Conceptual Model of Learning Ecology Design. Interdisciplinary Journal of Virtual Learning in Medical Sciences, 5(1), 33-45.

Richardson, J. C., Maeda, Y., Lv, J., \& Caskurlu, S. (2017). Social presence in relation to students' satisfaction and learning in the online environment: $A$ meta-analysis. Computers in Human Behavior, 71, 402-417.

Rogers, S., \& Van Haneghan, J. (2016, March). Rubric to evaluate online course syllabi plans for engendering a community of inquiry. In Society for Information Technology \& Teacher Education International Conference (pp. 346-354). Association for the Advancement of Computing in Education (AACE).

Rohimin, R., Mukti, W. A. H., Oktaviani, S., Erfan, M., \& Ratu, T. (2020). Comparison of Learning Outcomes Inquiry Learning Model with Cooperative Learning Model Type Number Head Together (NHT) Learning In Natural Sciences Class V In Public Elementary School 66 Bengkulu City. IJIS Edu: Indonesian Journal of Integrated Science Education, 2(2), 114118.

Rustam, H. K., \& Tentama, F. (2020). Creating academic stress scale and the application for students: Validity and reliability test in psychometrics. International Journal of Scientific and Technology Research, 9(01), 661-667.

Schumacher, C., \& Ifenthaler, D. (2021). Investigating prompts for supporting students' self-regulation-A remaining challenge for learning analytics approaches? The Internet and Higher Education, 49, 100791. 
الجمعية المصرية لتكنولوبيا التعليم

Schunk, D. H., \& Zimmerman, B. J. (2001). Self-Regulated. Learning and Academic Achievement: Theoretical, Perspectives 2nd ed., Lawren, ce Erlaum Assoc.

Shorer, M., \& Leibovich, L. (2020). Young children's emotional stress reactions during the COVID-19 outbreak and their associations with parental emotion regulation and parental playfulness. Early Child Development and Care, 1-11.

Sletten, S. R. (2017). Investigating flipped learning: Student self-regulated learning, perceptions, and achievement in an introductory biology course. Journal of Science Education and Technology, 26(3), 347-358.

Sreeramareddy, C. T., Shankar, P. R., Binu, V. S., Mukhopadhyay, C., Ray, B., \& Menezes, R. G. (2007). Psychological morbidity, sources of stress and coping strategies among undergraduate medical students of Nepal. BMC Medical education, 7(1), 1-8.

Suarez, A., Specht, M., Prinsen, F., Kalz, M., \& Ternier, S. (2018). A review of the types of mobile activities in mobile inquiry-based learning. Computers \& Education, 118, 38-55

Swan, K. (2019). Social Construction of Knowledge and the Community of Inquiry Framework.

Tao, D., \& Zhang, J. (2018). Forming shared inquiry structures to support knowledge building in a grade 5 community. Instructional Science, 46(4), 563592

Van Alten, D. C., Phielix, C., Janssen, J., \& Kester, L. (2019). Effects of flipping the classroom on learning outcomes and satisfaction: A metaanalysis. Educational Research Review, 28, 100281. 
Vohs, K. D., \& Baumeister, R. F. (Eds.). (2016). Handbook of self-regulation: Research, theory, and applications. Guilford Publications.

Watson, J. C., \& Watson, A. A. (2016). Coping self-efficacy and academic stress among Hispanic first-year college students: The moderating role of emotional intelligence. Journal of College Counseling, 19(3), 218-230.

Wong, T. L., Xie, H., Zou, D., Wang, F. L., Tang, J. K. T., Kong, A., \& Kwan, R. (2020). How to facilitate self-regulated learning? A case study on open educational resources. Journal of Computers in Education, 7(1), 51-77.

Wu, F., Qiu, J., Fan, Y., Zhang, Q., Cheng, B., Wu, Y., \& Bai, B. (2018). Apelin-13 attenuates ER stress-mediated neuronal apoptosis by activating Gai/GaqCK2 signaling in ischemic stroke. Experimental neurology, 302, 136-144.

Wu, J. Y., \& Nian, M. W. (2021). The dynamics of an online learning community in a hybrid statistics classroom over time: Implications for the questionoriented problem-solving course design with the social network analysis approach. Computers \& Education, 104120

Xing, W., \& Gao, F. (2018). Exploring the relationship between online discourse and commitment in Twitter professional learning communities. Computers \& Education, 126, 388-398.

Yandra, F. P., Alsolami, B., Sopacua, I. O., \& Prajogo, W. (2021). The role of community of inquiry and self-efficacy on accounting students' satisfaction in online learning environment. Jurnal Siasat Bisnis, 25(1). 
الجمعية المصرية لتكنولوبيا التعليم

Yen, C. J., Tu, C. H., Sujo-Montes, L. E., Armfield, S. W., \& Chan, J. Y. (2016). The Relationship between Self-Regulated Learning and PLE Management. In Revolutionizing Education through Web-Based Instruction (pp. 253-280). IGI Global.

Yikealo, D., Tareke, W., \& Karvinen, I. (2018). The level of stress among college students: A case in the college of education, Eritrea Institute of Technology. Open Science Journal, 3(4).

Yıldırım, N., Karaca, A., Cangur, S., Acıkgoz, F., \& Akkus, D. (2017). The relationship between educational stress, stress coping, self-esteem, social support, and health status among nursing students in Turkey: A structural equation modeling approach. Nurse education today, 48, 33-39.

Zarzour, H., Bendjaballah, S., \& Harirche, H. (2020). Exploring the behavioral patterns of students learning with a Facebook-based e-book approach. Computers \& Education, 156, 103957

Zenner, C., Herrnleben-Kurz, S., \& Walach, H. (2014). Mindfulness-based interventions in schools - a systematic review and meta-analysis. Frontiers in psychology, 5, 603.

Zhang, J. (2020). The Construction of College English Online Learning Community under ADDIE Model. English Language Teaching, 13(7), 46-51

Zhang, S., Wen, Y., \& Liu, Q. (2019). Exploring student teachers' social knowledge construction behaviors and collective agency in an online collaborative learning environment. Interactive learning environments, 1-13 
Zheng, L. (2016). The effectiveness of self-regulated learning scaffolds on academic performance in computer-based learning environments: A metaanalysis. Asia Pacific Education Review, 17(2), 187-202.

Zimmerman, B. J., \& Moylan, A. R. (2009). Self-Regulation: Where Metacognition and Motivation Intersect. In Handbook of Metacognition in Education (pp. 311-328). Routledge.

Zimmerman, B. J., \& Schunk, D. H. (2011). Self-regulated learning and performance. Handbook of self-regulation of learning and performance, 1-12. 